Florida International University FIU Digital Commons

$11-9-2011$

\title{
European Integration and Democratic Consolidation: Spain, Poland and Turkey in Comparative Perspective
}

Engin I. Erdem

Florida International University, erdemengin@gmail.com

DOI: $10.25148 /$ etd.FI11120509

Follow this and additional works at: https://digitalcommons.fiu.edu/etd

\section{Recommended Citation}

Erdem, Engin I., "European Integration and Democratic Consolidation: Spain, Poland and Turkey in Comparative Perspective" (2011). FIU Electronic Theses and Dissertations. 486.

https://digitalcommons.fiu.edu/etd/486 


\section{FLORIDA INTERNATIONAL UNIVERSITY}

Miami, Florida

EUROPEAN INTEGRATION AND DEMOCRATIC CONSOLIDATION:

SPAIN, POLAND AND TURKEY IN COMPARATIVE PERSPECTIVE

A dissertation submitted in partial fulfillment of

the requirements for the degree of

DOCTOR OF PHILOSOPHY

in

POLITICAL SCIENCE

by

Engin Ibrahim Erdem

2011 
To: Dean Kenneth G. Furton

College of Arts and Sciences

This dissertation, written by Engin Ibrahim Erdem, and entitled European Integration and Democratic Consolidation: Spain, Poland and Turkey in Comparative Perspective, having been approved in respect to style and intellectual content, is referred to you for judgment.

We have read this dissertation and recommend that it be approved.

Ronald Cox

Dario Moreno

Barry Levitt

Cem Karayalcin

Tatiana Kostadinova, Major Professor

Date of Defense: November 9, 2011

The dissertation of Engin Ibrahim Erdem is approved.

Dean Kenneth G. Furton

College of Arts and Sciences

Dean Lakshmi N. Reddi

University Graduate School

Florida International University, 2011 
(C) Copyright 2011 by Engin Ibrahim Erdem

All rights reserved. 


\section{DEDICATION}

I dedicate the dissertation to my family;

to my Mom and Dad,

elder sister,

two elder brothers,

maternal grandparents,

and

the memory of my paternal grandparents.

Without their love and unconditional support, this dissertation could not have been written. 


\section{ACKNOWLEDGMENTS}

I would like to express my thanks to the Committee members. Dr. Tatiana Kostadinova, my major professor, has provided continuous support and invaluable feedback throughout the study. Dr. Ronald Cox's critical remarks have helped me in sharpening the theoretical framework. In addition, Professors Kostadinova and Cox, as the graduate directors of Political Science program, contributed to the presence of an excellent academic environment during my graduate years at FIU. Dr. Barry Levitt's comments on the methodology and the case studies have been very helpful. Dr. Dario Moreno and Dr. Cem Karayalcin have been very generous with their feedback and timely support.

Moreover, I would like to thank FIU's Graduate School and the Miami-Florida European Union Center for their financial support to undertake field studies in Spain, Poland, and Turkey. The University Graduate School's Dissertation Evidence Acquisition Fellowship and the EU Center's graduate student research grant enabled me to gather primary data for this study.

Finally, I thank all interviewees whom I talked to in the three countries. Their opinions and insights have been most useful in examining the power and the limits of the EU's democratizing impact in Spain, Poland, and Turkey. 


\begin{abstract}
OF THE DISSERTATION
EUROPEAN INTEGRATION AND DEMOCRATIC CONSOLIDATION:

SPAIN, POLAND AND TURKEY IN COMPARATIVE PERSPECTIVE
\end{abstract}

\author{
by
}

\title{
Engin Ibrahim Erdem
}

Florida International University, 2011

Miami, Florida

\section{Professor Tatiana Kostadinova, Major Professor}

The study explored when, under what conditions, and to what extent did European integration, particularly the European Union's requirement for democratic conditionality, contribute to democratic consolidation in Spain, Poland, and Turkey? On the basis of a four-part definition, the dissertation examined the democratizing impact of European integration process on each of the following four components of consolidation: (i) holding of fair, free and competitive elections, (ii) protection of fundamental rights, including human and minority rights, (iii) high prospects of regime survival and civilian control of the military, and (iv) legitimacy, elite consensus, and stateness. To assess the relative significance of EU's democratizing leverage, the thesis also examined domestic and non-EU international dynamics of democratic consolidation in the three countries.

By employing two qualitative methods (case study and process-tracing), the study focused on three specific time frames: 1977-1986 for Spain, 1994-2004 for Poland, and 1999-present for Turkey. In addition to official documents, newspapers, and secondary sources, face-to-face interviews made with politicians, academics, experts, bureaucrats, and journalists in the three countries were utilized. 
The thesis generated several conclusions. First of all, the EU's democratizing impact is not uniform across different components of democratic consolidation. Moreover, the EU's democratizing leverage in Spain, Poland, and Turkey involved variations over time for three major reasons: (i) the changing nature of EU's democratic conditionality over time (ii) varying levels of the EU's credible commitment to the candidate country's prospect for membership, and (iii) domestic dynamics in the candidate countries. Furthermore, the European integration process favors democratic consolidation but its magnitude is shaped by the candidate country's prospect for EU membership and domestic factors in the candidate country. Finally, the study involves a major policy implication for the European Union: unless the EU provides a clear prospect for membership, its democratizing leverage will be limited in the candidate countries. 


\section{TABLE OF CONTENTS}

CHAPTER

PAGE

CHAPTER I

INTRODUCTION

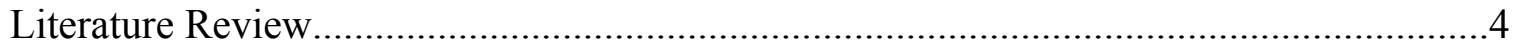

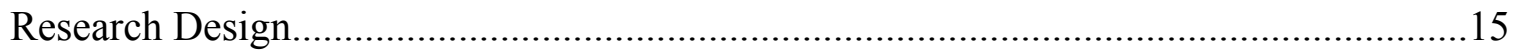

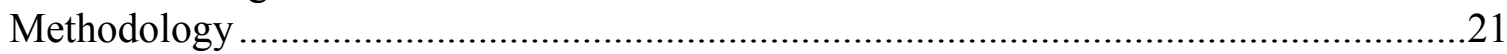

Data

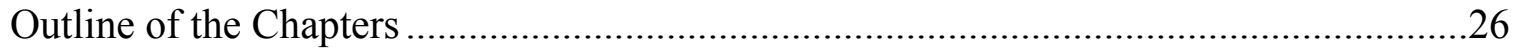

CHAPTER II

INTERNATIONAL DYNAMICS, EUROPEAN INTEGRATION AND

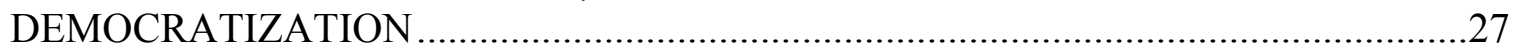

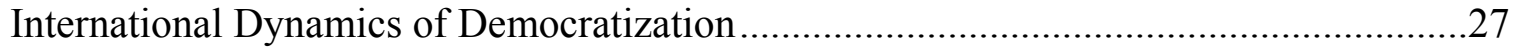

European Integration and Democracy Promotion..........................................................36

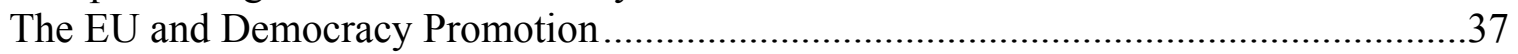

The EU's Democratizing Impact in the Southern and the CEE Enlargements...................40

Historical Evolution of the EU's Democratic Conditionality ............................................44

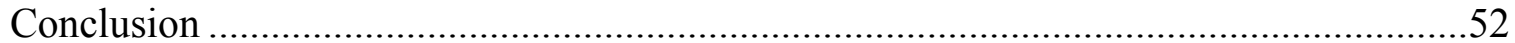

\section{CHAPTER III}

EUROPEAN INTEGRATION AND DEMOCRATIC CONSOLIDATION: THE CASE

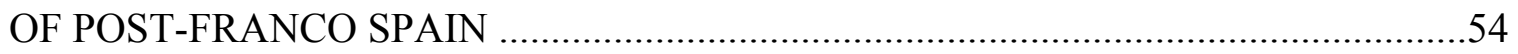

The Spanish Transition to Democracy: A Nuanced and Eclectic Approach ......................56

The Consolidation Process and the Democratic Impact of European Integration ..............66

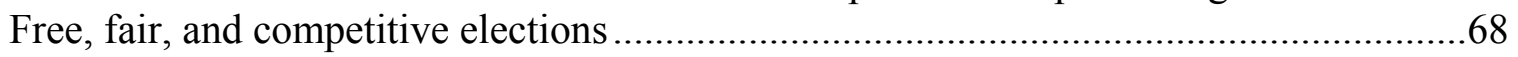

Protection of fundamental rights and liberties ............................................................71

High prospects of regime survival and civilian control of the military …….....................74

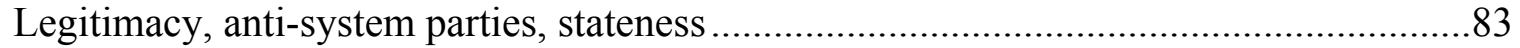

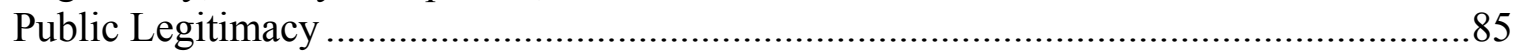

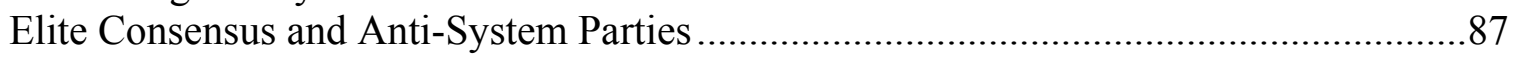

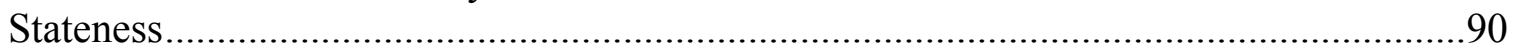

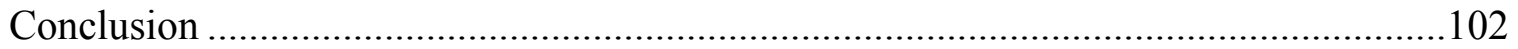

\section{CHAPTER IV}

EUROPEAN INTEGRATION AND DEMOCRATIC CONSOLIDATION: THE CASE

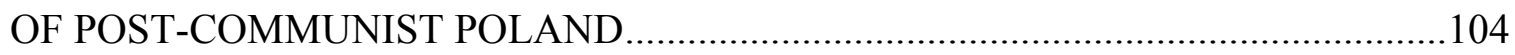

The Polish Transition to Democracy: A Peaceful but Revolutionary Regime Change...106

The Consolidation Process and the Democratic Impact of European Integration ............115

Free, fair, and competitive elections ......................................................................116

Protection of fundamental rights and liberties ............................................................118

High prospects of regime survival and civilian control of the military ...........................124

Legitimacy, anti-system parties, stateness ..................................................................135 


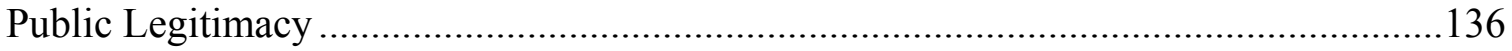

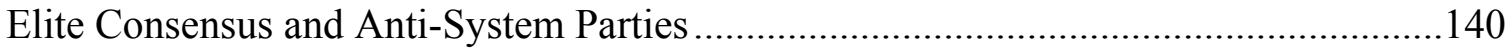

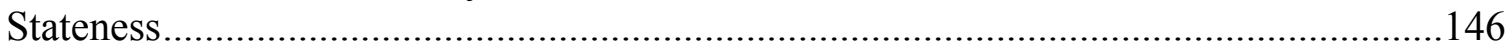

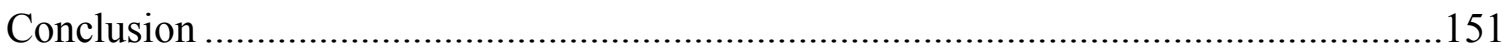

CHAPTER V

EUROPEAN INTEGRATION AND DEMOCRATIC CONSOLIDATION: THE CASE

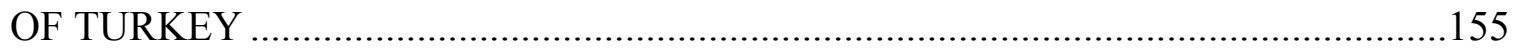

Earlier is Not Always Better: Turkey's Transition to Democracy (1946-50) .................156

The Consolidation of Turkish Democracy and the EU Accession Process .......................162

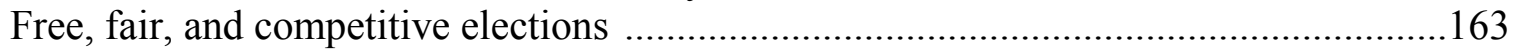

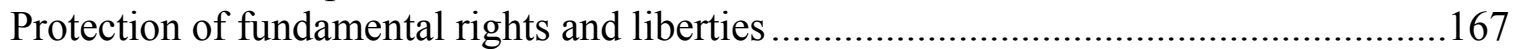

High prospects of regime survival and civilian control of the military ...........................181

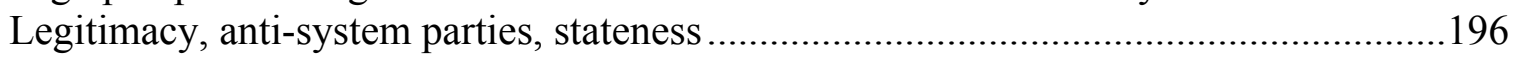

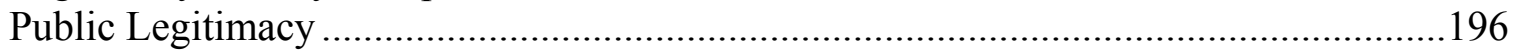

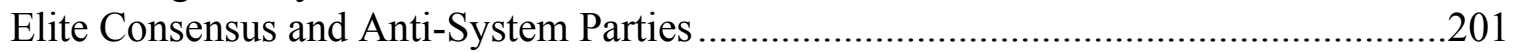

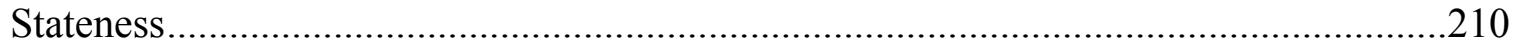

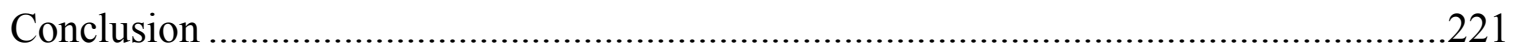

CHAPTER VI

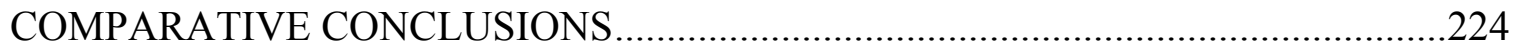

Summary of Findings and Cross-National Observations...............................................224

Revisiting Hypotheses and the Research Question....................................................228

Domestic Dynamics of Democratic Consolidation........................................................232

Non-EU International Dynamics of Democratic Consolidation......................................235

Implications for Future Research............................................................................238

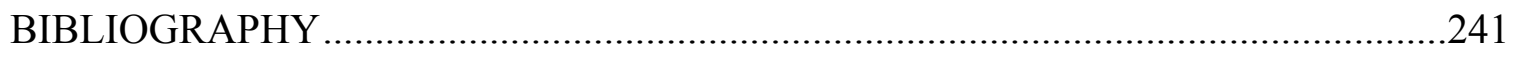

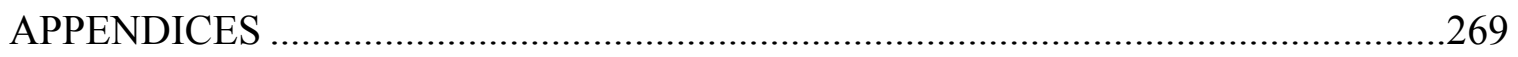

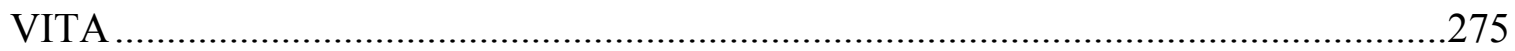




\section{LIST OF TABLES}

TABLE

PAGE

Table 3.1.Key Actors in the Spanish Transition ...............................................................61

Table 3.2.Political Rights (PR) and Civil Liberties (CL) Scale in Spain (1975-1986) .....72

Table 3.3.Turnout Rates in Spanish Referendums and Elections (1976-1986).................85

Table 3.4.The Legitimacy of Democracy in Spain, 1980-1990 ……………………........86

Table 3.5.Basque Election Results, 1980 to 1990 .........................................................93

Table 3.6.European versus Domestic Dynamics of the Consolidation...............................97

Table 4.1.Key Actors in the Polish Transition................................................................113

Table 4.2.Polish Parliamentary Elections (1991- 2001) ................................................141

Table 4.3.Governments in Poland (1991-2004) ..........................................................142

Table 4.4.European versus Domestic Dynamics of the Consolidation..............................149

Table 5.1.Participation in Parliamentary Elections, 1950-2011 .....................................197

Table 5.2.Turkish Parliamentary Elections (1995-2011)..................................................205

Table 5.3.European versus Domestic Dynamics of the Consolidation $\quad$........................217

Table 6.1.The European Integration Process and Four Components of Democratic

Consolidation: Spain, Poland, and Turkey in a Comparative Perspective ......................229

Table 6.2.Overview of Domestic and Non-EU International Dynamics of Democratic

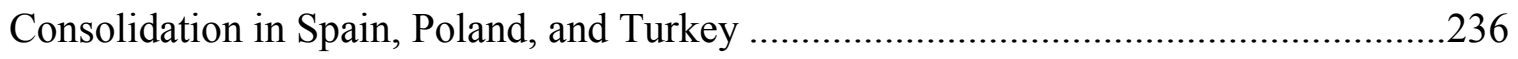




\section{CHAPTER I}

\section{INTRODUCTION}

Do international organizations matter for democratic consolidation? In recent years, increasing numbers of studies have argued that international organizations have made substantial contributions to democratic consolidation processes in many countries. ${ }^{1}$ Within this body of scholarly works, the democratizing impact of the European Union (EU) has attracted a great amount of attention. Particularly important, the EU's democratic conditionality for membership has been considered as a powerful mechanism leading to institutional and normative changes in the EU candidate countries. ${ }^{2}$ These changes have been related to a wide range of issues such as fundamental rights and freedoms, civil-military relations, human and minority rights, corruption, and judicial reforms. Yet, the EU's democratizing impact has not been uniform among the candidate countries as the impact has involved variations across different countries during the EU accession process. Then, one should deal with the central question: when and under what conditions the European Union plays a democratizing role for the candidate countries? Identifying these conditions will help us understand why the EU's impact varies across countries and over time. It will also illuminate the relative salience of the EU's

\footnotetext{
${ }^{1}$ For example; Pevehouse 2005, Ziolanka 2001, Kelley 2004 and Magen et al 2008

${ }^{2}$ For instance; Linden 2002, Pridham 2001, Vachudova 2005, Kubicek 2003, Dimitrova 2004, Grabbe 2006, Pop-Eleches 2007, Schimmelfennig et al 2005, Williams 1999, Haughton 2007, Schimmelfenning 2007, Pridham 2002, and Rechel 2008. While the EU driven institutional changes may involve the adoption of laws conforming to the EU's requirement for democratic conditionality, the normative changes can refer to the spread of democratic norms among political elite and people in the candidate countries.
} 
democratizing role vis-à-vis the domestic dynamics of democratic consolidation in these countries.

The dissertation will attempt to explain these conditions through a comparative study of Spain, Poland and Turkey. Choosing one country from each of three different waves of European enlargement offers an opportunity to assess to what extent the EU's democratizing role varies over time. ${ }^{3}$ Moreover, a detailed analysis of the three cases would enable an assessment of the extent to which domestic political dynamics contribute to and/or limit the EU's democratizing impact. The existing literature in this area has discussed a variety of intervening variables that work with or against the EU's democratic conditionality. ${ }^{4}$ Through a careful examination of domestic politics in Spain, Poland and Turkey during the EU accession process, the dissertation is expected to identify significant domestic factors that shaped the EU's democratizing influence. For this purpose, the study will employ process-tracing method to explore the connections among the EU's democratic conditionality, domestic intervening variables, and democratic consolidation. The analysis of sequences of events - process tracing-, will enable us to identify the degree to which the three countries have implemented democratization reforms in line with the EU's conditionality principle. In the end, the study will help to build a thorough understanding of when, how and under what

\footnotetext{
${ }^{3}$ For example, the EU's 1993 Copenhagen Criteria, which set the democratic conditionality for the Central and Eastern European candidates, include the areas relating to human and minority rights. These areas were not part of the democratic conditionality during the Southern enlargement (1975-86).

${ }^{4}$ For example; the EU's credibility for the membership goal, the degree to which government in the candidate country has a commitment to the prospect of EU membership, the elections, party composition of the national parliaments, the level of elite and mass support for the EU membership (Pridham 2001, Vachudova 2005, Grabbe 2006, Kelley 2004).
} 
conditions European integration matters for the democratic consolidation of the three countries.

The study has significance for both theoretical and policy-related reasons. On the theoretical side, it will contribute to three major bodies of literature: (i) international dynamics of democratization (ii) the domestic-international linkages, and (iii) European enlargement. With cross-country and within-country comparisons, the dissertation will go beyond the simple question of whether domestic or international dynamics of democratization matter most; it will offer a more nuanced analysis that respects spatial and temporal variations. In addition, the study will contribute to recent debates on how domestic and international politics are linked to each other. ${ }^{5}$ Finally, the comparative study of three EU candidate countries will contribute to the literature on European enlargement. Overall, the dissertation is expected to enhance our knowledge in the specified fields of international relations, comparative politics and European studies.

The study is also significant for the policy world. Comparative study of Spain, Poland and Turkey has a potential to generate policy recommendations for both the EU and the candidate (current and future) countries. For example, the Spanish and Polish experiences might provide lessons for the ongoing process of Turkey-EU accession negotiations, and help in assessing the EU's contribution to the Turkish democracy. Finally, the analysis of the EU's democracy promotion could generate policy conclusions for regional organizations in other parts of the world.

\footnotetext{
${ }^{5}$ For example; Gourevitch 1978, Katzenstein 1978, Gourevitch 1986, Putnam 1988, Evans et al 1993, Keohane and Milner 1996, and Sikkink 2005.
} 


\section{Literature Review}

The dissertation inquiry is situated at the intersection of three bodies of research.

First, it is related to the democratization literature in comparative politics, particularly to the arguments emphasizing international dynamics of regime change. Second, the literature on domestic-international linkages in international relations provides a key theoretical framework for the research project. Third, the Europeanization and EUization (of the member and candidate countries) literature in the area of European studies, including works on the EU's democratic conditionality, is another major point of departure for the dissertation work. In what follows, a brief review of the three bodies of research will take place.

\section{(i) International Dynamics of Democratization}

The democratization studies have constituted an important component of the discipline of political science in the past half-century. Cultural and structural arguments were the dominant mode of thinking in the 1950 and 1960s. While Almond and Verba's The Civic Culture (1963) linked democratic stability to civic attitudes, Barrington Moore's Social Origins of Dictatorship and Democracy (1966) brought a powercentered, class coalitional analysis of regime change. Modernization theories of democratization argued for a causal relationship between economic development and democracy. Lipset's seminal article, "Some Social Requisites of Democracy” (1959) was a pioneer of these studies.

Later, the literature witnessed the rise of critics of liberal modernization theories. The bureaucratic-authoritarian model of authoritarianism, driven by the Marxist 
dependency theory, asserted that dependent capitalist development resulted in authoritarianism rather than democracy in the developing countries. ${ }^{6}$ In addition, modernization theory attracted criticisms beyond the dependency theorists. One important critic of the theory in the 1960s, Samuel Huntington, contended that high levels of political participation, in the absence of corresponding political institutions, caused political instability and democratic breakdowns in the developing countries. ${ }^{7}$ Therefore, he underlined the significance of political institutions for the stability of democratic regimes.

In the 1970s and 1980s, the "transitology" studies in the literature shifted attention to non-structural dynamics such as moderation, contingency, leadership-elites, and bargaining. In this respect, Dankwart Rustow's article, "Transitions to Democracy" (1970) and O'Donnell and Schmitter's edited, multi-volume work, Transitions from Authoritarian Rule (1986) can be noted as major examples. Indeed, the increase in cases of democratic transitions from the mid-1970s to the early 1990s (the "third wave" of democratization ${ }^{8}$ ) made the "transitology" genre highly relevant for the policy world.

In the 1990s, the democratization literature witnessed a growing number of eclectic studies. Huntington's The Third Wave (1992), Rueschemeyer et al's Capitalist Development and Democracy (1992), Linz and Stepan's Problems of Democratic Transition and Consolidation (1996) and Ruth Collier's Paths to Democracy (1999) can be taken as key examples of these studies. The central feature of the eclectic studies is

\footnotetext{
${ }^{6}$ For a larger discussion on this approach, see Collier 1979, The New Authoritarianism in Latin America.

${ }^{7}$ Huntington 1968, Political Order in Changing Societies

${ }^{8}$ Huntington 1992, The Third Wave: Democratization in the Late Twentieth Century
} 
their inclusion of multiple factors (economic development, state, class, elites, institutions, prior regime type, civil society, attitudes etc.) to explain the democratic transitions and consolidations.

A major weakness for the democratization literature, from the 1950s to the early 1990s, was related to the domestic orientation of comparative politics. The research on regime change focused primarily on domestic factors, and ignored international dynamics to a large extent. ${ }^{9}$ Two major developments in world politics have posed serious challenges for the domestic bias. First, the unexpected collapse of the Soviet Union and the breakdown of communist systems in Central and Eastern Europe (CEE) have demonstrated the importance of international factors for democratic transitions. Later, the EU membership process, particularly the democratic conditionality, resulted in sweeping democratic reforms in the CEE countries. Second, the increasing salience of international financial institutions, NGOs, and international organizations in the contemporary age of globalization has made the boundaries between the domestic and the international less visible. All these developments require the democratization literature to pay more attention to international factors (Remmer 1995: 103-106).

Taking international actors into consideration to explain democratization processes comes with two major challenges. First, a variety of international factors can

\footnotetext{
${ }^{9}$ A few exceptions should be noted here; In Polyarchy: Participation and Opposition (1971) R. Dahl put foreign control/domination as one of the seven key conditions shaping democratic transitions. In addition, Theda Skocpol's States and Social Revolutions (1979) emphasized the importance of international contexts for the outbreak of revolutions in France, China and Russia. Moreover, the bureaucratic authoritarianism approach held that the oligarchy of bureaucratic-technocratic elite (coalition of military, domestic bourgeois and international capitalists) resulted in authoritarianism in many Latin American countries in the 1960s and 1970s. Finally, the Transitions from Authoritarian Rule (1986) project assessed the role of US and European policies of democracy promotion for democratic transitions in the 1970s and 1980s. However, the project provided only a secondary importance to international factors while assigning the primary role to domestic dynamics.
} 
have influence over democratic transitions and consolidations. International organizations, NGOs, regional organizations, transnational party linkages, the Catholic Church, the international political system, international economic crises and globalization itself all might play a role when a country experiences democratic breakdown, transition or consolidation. Then, one should identify the degree to which each relevant international factor has a positive or negative effect in these processes. Of course, this task is not an easy one, as it requires a rigorous effort to deal with the causal mechanism between international factors and regime change outcomes.

The second challenge is related to the interaction between domestic and international dynamics of democratization. Although the domestic phenomena alone may not be sufficient to understand the causes and nature of democratization, they are critically important not only in making a direct impact on democratization but also in responding to international dynamics. In other words, the international does not work in a vacuum; its impact has been filtered through domestic politics (Remmer 1995, Keohane and Milner 1996).

\section{(ii) Domestic-International Linkages}

The domestic-international linkages genre is a relatively new research area in the field of international relations. The two major International Relations (IR) theories, realism/neorealism and neo-liberal institutionalism, have dealt with neither international sources of domestic politics nor the domestic-international interactions. The state-centric realist theories have been primarily interested in international outcomes such as war and alliances, and they have not assigned any autonomous role to international institutions 
and multinational corporations (MNCs) (Waltz 1979, Mearsheimer 1994). In contrast to the realist theories, neo-liberal institutionalism has underlined the importance of MNCs and international organizations to promote cooperation among states (Keohane and Nye 1977). Nonetheless, the neo-liberal focus has to a large extent remained at the international level with little attention to the domestic impact of international politics.

Three major developments have brought the domestic-international linkages into the forefront of the disciplinary agenda in the IR field. First, the 1973 oil crisis and subsequent developments have puzzled many IR scholars trying to explain different domestic responses to the crisis. The major challenge has been to explain why the international impact differs across countries. The research question made unpacking domestic politics necessary to understand cross-country variation. Then, many scholars got involved into the study of the domestic-international linkages. Peter Gourevitch's path-breaking article, "The Second Image Reversed" (1978), and his book, Politics in Hard Times (1986) along with Peter Katzenstein's Between Power and Plenty (1978) can be taken as foremost examples in this genre.

Second, the rising pace of globalization in the 1980s and the 1990s expanded this research. Keohane and Milner's edited volume, Internationalization and Domestic Politics (1996) asked how and through which mechanisms economic globalization influences national economic policies. The study emphasizes the significance of two intervening variables -domestic interests/coalitions and domestic institutions- to understand the differential impact of economic globalization across countries. ${ }^{10}$

\footnotetext{
${ }^{10}$ While the Frieden and Rogowski chapter in this volume takes domestic coalitions as the key intervening variable, the Garrett and Lange chapter stresses the importance of domestic institutions.
} 
Third, transnational actors and relations have been increasingly salient features of world politics in recent decades. Several scholars of sociological institutionalism/constructivism have argued that non-state actors including NGOs, international organizations, transnational social movements and advocacy networks have changed the state behavior regarding the rules of war, human rights, development, environment and women's rights. ${ }^{11}$ An important finding from the transnational relations studies is that the transnational impact is not a given; rather, the impact is contingent upon the domestic politics of target countries. For example, Kathryn Sikkink's model of "dynamic multilevel governance" suggests that the level of success for a transnational advocacy network depends on the nature of opportunity structure at both the domestic and international levels (2005: 151-55). For example, if a transnational human rights campaign cannot find a strong ally or favorable structure at the domestic level, then it is less likely to change the state behavior. As a result, the domestic-international linkages are critically important in order to explain the differential impact of transnational actors across countries.

Arguing that international economic forces, international organizations and transnational actors have increasingly shaped state behavior and domestic politics is not enough. The key challenge here is to identify significant domestic variables that interact with the international or the transnational factors. The domestic-international linkages literature is a relatively new research frontier in the field of international relations. By challenging the conventional boundaries between comparative politics and international relations, this literature is faced with two major tasks. First, it needs to establish models

${ }^{11}$ For example, Finnemore 1996, Keck and Sikkink 1998, Khagram et al 2002 
that can successfully integrate the domestic and international levels of analysis. Second, it has to specify relevant domestic dynamics that pave the way for the differential impact of the international/transnational across countries. A good opportunity to handle these tasks is provided by the research on the European Union's democratizing efforts in the candidate countries.

\section{(iii) Europeanization, "EUization" and Democratic Conditionality}

A concrete regional case for the first two literatures discussed earlier comes from

Europe. In this regard, two overlapping bodies of research, Europeanization and

EUization, have provided a good opportunity to examine how regionalization of domestic politics can occur. While Europeanization studies have been dealt with public policies and legislation of the EU member states ${ }^{12}$, the research on EUization has examined the EU's pressures over the candidate countries to comply with the acquis communautaire ("EU acquis"), which refers to the total body of EU law. ${ }^{13}$ The European Union has required the candidate countries to meet the Union's democratic conditionality before launching the accession negotiations, which are mostly dealt with the harmonization of candidate countries' legislation with the EU acquis. An important puzzle in this area is

\footnotetext{
${ }^{12}$ Three major examples of such studies; Caporaso et al (eds) 2001, Transforming Europe: Europeanization and Domestic Change, Schimmelfennig et al (eds) 2005, The Europeanization of Central and Eastern Europe, Featherstone and Radaelli (eds) 2003, The Politics of Europeanization.

${ }^{13}$ The EU acquis involves more than one hundred thousand pages that includes the treaties on which EU was formed, the changes to these treaties, the legislation enacted by the EU institutions (the Commission, the Council, the Court of Justice i.e.), and the EU's declarations and resolutions. Candidate countries have to accept the 'acquis' before they join the EU, and must make the acquis part of their national legislation. In addition to fulfilling the political criteria, alignment with the EU acquis chapters ( 31 chapters for the CEE candidates, 35 chapters for Croatia and Turkey) constitutes the heart of accession negotiations between the $\mathrm{EU}$ and candidate countries. Complying with the acquis requires extensive standardization of public policies among the EU member states. On the acquis chapters, see "Chapters of the acquis" at the website of the EU: http://ec.europa.eu/enlargement/enlargement_process/accession_process/how does_a country_join_the eu /negotiations_croatia_turkey/index_en.htm\#5
} 
that the EU candidate countries complete this process within varying periods of time. While some countries followed a faster path in the accession process, other countries met the democratic conditionality and the EU acquis requirements in a longer time frame. Domestic politics of the candidate countries emerges as critically important in explaining this variation.

The literature in this area has thus far discussed a variety of domestic factors that shaped the EU's democratizing impact. For example, Pridham 2001 argues that consensus among political parties over the EU accession process is a major dynamic. In addition, the study underlines the commitment level of the governing party to the EU process. Then, one can expect that a candidate country with a high degree of cross-party consensus and political will for membership will handle the EU related democratization reforms in a shorter period of time. Otherwise, the EU may have limited democratizing impact when it encounters a political landscape that is not very favorable at the party and government level, for European integration. In this regard, Pridham and many others have noted a clear cut example: Slovakia under the 1994-98 Meciar government. The authoritarian, nationalist, and Euro-skeptical Meciar government retarded the country's bid for the EU membership, and fell behind the first-track CEE candidate countries, which started accession negotiations in March $1998 .{ }^{14}$ Later, Slovakia's EU process did get accelerated only after the election of the pro-EU Dzurinda government in October 1998. The significance of government change through elections was also relevant for Bulgaria and Romania. The 1996 presidential elections in Romania and the 1997

\footnotetext{
${ }^{14}$ These countries are Poland, the Czech Republic, Hungary, Slovenia, Estonia, and Cyprus.
} 
parliamentary elections in Bulgaria created a more favorable domestic context for the EU's democratizing impact (Vachudova 2005).

The literature on the EU's democratic conditionality cites several other domestic factors that substantially shape the EU's democratic leverage. These factors include mass and elite support for EU membership, availability of pro-EU groups in society, adoption costs of the EU related reforms for government and state elites, ethnic nationalism, and cultural traditions/norms (Kelley 2004, Williams 1999, Checkel 1999, Ziolanka 2001, Schimmelfennig 2007, Rupnik 2000, Pridham 2002, Kubicek 2003). The existence of numerous factors poses a serious challenge in identifying the causal process between the EU impact and the democratization outcome. For this reason, the analysis of domestic politics is indispensable in explaining the relative value of European integration for the candidate countries. In this regard, the domestic-international linkages framework offers a good opportunity to handle such a research task.

How does the European Union promote democracy in the candidate countries? The EU has several mechanisms of influence such as the provision of legislative and institutional templates, monitoring through annual progress reports, financial assistance, and the democratic conditionality principle (Grabbe 2006, Schimmelfennig et al 2005). Particularly important, the strict democratic conditionality rules have succeeded in paving the way for fundamental institutional and normative changes in favor of better democratic standards in the candidate countries. Moreover, the European integration process has made some indirect democratizing impacts: socializing elites, institutions and society into democratic norms and attitudes, empowering pro-democracy groups, and promoting 
better democratic governance through public administration reforms (Pevehouse 2005, Pop-Eleches 2007).

An important finding from the studies on European integration is that the EU's democratizing impact varies across countries and over time. As suggested earlier, variation across countries is much related to the domestic political structure of candidate countries. For the temporal variation, many scholars have underlined the changing status of relationship between the EU and the candidate country. In the case of Eastern enlargement, the EU did not have much democratizing leverage in the early 1990s, when it avoided giving a clear prospect for full membership. With the establishment of the Copenhagen conditionality rules in 1993, the EU did have an increasing amount of leverage on the candidate countries (Grabbe 2006, Vachudova 2005, Atanasova 2004, Rupnik 2000). Furthermore, the EU's democratizing impact has varied across different policy areas such as human rights, minority rights, public administration and judicial reforms (Dimitrova 2004, Ram 1999, Haughton 2007). For example, Bernd Rechel argues that the EU has had only a limited impact on minority rights in Bulgaria for several reasons: the failure of addressing public attitudes towards minorities, the absence of clear EU conditionality in this policy area, superficial monitoring, and the lack of expertise on minority rights (2008: 171). Overall, the existing literature asserts that the EU's democratizing impact is not uniform; it varies across the candidate countries, policy areas and over time. In this regard, comparisons across the different EU candidate countries could be very helpful to identify these variations. 


\section{The Three Literatures and the Dissertation: Potential Areas of Contribution}

The dissertation will contribute to the three literatures in several ways. First, the three literatures are relatively new areas of academic interest in the discipline of political science. Even though there has been increasing attention to these issues over the past two decades, the theoretical ground is still underdeveloped and warrants further research. A comparative study of Spanish, Polish and Turkish democracy in the context of European integration, if theoretically grounded and methodologically rigorous, can enhance our knowledge in the three research areas.

Second, the attempt to understand the relative significance of European integration for democratic consolidation processes of these countries requires unpacking the domestic politics. The domestic-international linkages framework is a necessary part of the inquiry about the international sources of democratic consolidation. By carefully examining the domestic political contexts of Spain, Poland, and Turkey through the process-tracing method, the dissertation will identify the power and the limits of European integration for democratic consolidation. In particular, such a comparative study will help to clarify the relevant domestic intervening variables which shape the EU's democratizing impact.

Third, choosing one country from the three different waves of European enlargement will illuminate the varying nature of EU conditionality rules over time. The dissertation would be a good addition to studies that compare and contrast different EU enlargement phases. Finally, the research outcome will contribute to studies that examine the conditions under which regional/international organizations help foster democratic consolidation. 


\section{Research Design}

Research Question: When, under what conditions, and to what extent did European integration, particularly the European Union's democratic conditionality, contribute to democratic consolidation in Spain, Poland, and Turkey?

The question deals with two major research tasks: (1) to clarify the causal mechanism of the interaction between EU's democratizing impact and domestic political factors, and (2) to assess the relative significance of the EU's democratizing role vis-à-vis the domestic and non-EU international dynamics of democratization in these countries.

\section{Hypotheses:}

\# 1 The European integration process, particularly the EU's democratic conditionality, favors democratic consolidation but its magnitude is conditioned by domestic factors. Therefore, one can expect that the EU's democratizing impact will be limited in the face of an unfavorable domestic context. In addition, the candidate country will have faster progress in the process of democratic consolidation when favorable domestic factors converge with the EU promoted political reforms.

\# $\mathbf{2}$ The degree to which the candidate country has prospect for membership affects the democratizing leverage of the European Union. Then, the hypothesis generates the following expectation: the EU's democratizing contribution will not be significant unless the EU provides a clear prospect of membership.

The existing literature on European integration has suggested several domestic factors that shape the EU's democratizing impact: the degree to which the national government has a commitment to the EU membership process, the degree to which 
parties in the parliament have support for the EU accession process, and the level of mass support for European integration. The process-tracing analysis of the three cases will identify the relevant domestic factors in influencing the EU's democratizing impact.

\section{Independent Variable}

The independent variable in this dissertation is the European integration process, which refers to the EU's institutional and non-institutional dynamics of democratization in the period preceding accession to the Union. Henceforth, the EU's democratization effects after the accession will not be part of the dissertation. The study will observe the EU's democratizing impact in Spain, Poland, and Turkey for the following years, respectively: 1977-86, 1994-2004, and 1999 to present. As a result, the European integration process in this study will be bounded by a temporal limit.

The EU's democratizing impact in the dissertation is operationalized through the EUs institutional and non-institutional dynamics of democracy promotion. The EU's policy of democratic conditionality is the pillar of institutional dynamics. In addition, legislative and institutional templates, monitoring through annual progress reports and the membership prospect are other key resources that give the EU an important leverage to shape democratization processes of the candidate countries.

As for non-institutional effects of the European integration process, two dynamics are noteworthy. First, accession to the European Union, which is composed of only democratic members, poses a significant symbolic value for the candidate countries. As a result, the EU accession signifies having both European and democratic identity for these 
countries. Second, the European integration process includes a dynamic of socialization to democratic norms for political, economic, and intellectual elites of the candidate countries through communication with not only the EC institutions but also European political parties and civil society.

In assessing the democratizing impact of European integration in the preaccession period, the dissertation will also look at whether and to what extent non-EU international factors play a role at that time. In this regard, the Council of Europe, NATO, and the Organization of Security and Cooperation in Europe (OSCE) are the major international players, which may have democratizing effects in the EU candidate countries.

\section{Dependent Variable}

The dependent variable is democratic consolidation. However, in the existing literature on democratization, there is no standard, commonly agreed definition for it. Many scholars agree that democratic consolidation is largely a separate phenomenon from democratic transition although the two may sometime overlap in a period of time.

\section{Democratic Consolidation: A Conceptual Discussion}

Defining democratic consolidation is not an easy task. In parallel with the existence of various definitions of democracy in the literature, the concept of democratic consolidation suffers a similar problem. Some scholars argue that democratic consolidation is primarily related to the prospect of regime survival. Then, the key issue at stake is the degree to which democracy is free from the risk of a breakdown (Schedler 1998: 103-5). As a result, consolidated democracies differ from unconsolidated 
democracies in thay they enjoy higher prospects of endurance. According to maximalist accounts of democratic consolidation, consolidated democracies are distinct by a higher quality along many dimensions such as state-society relations, legislative-executive relations, participation, and equality. ${ }^{15}$

Although it is not easy to draw a clear-cut line when identifying consolidation, one can discuss several elements that make a democracy less or more consolidated. First, rulers are elected by free and fair elections through universal suffrage. However, holding elections is not enough to make a democracy consolidated. In addition, some behavioral and normative characteristics are also required. On the behavioral side, many scholars have suggested that democratic control of the military and absence of strong anti-system parties/groups are essential for the consolidation (Huntington 1991, Valenzuela 1992, Gunther and Higley 1992, Mainwaring et al 2000, Pridham 2001). If a country experiences coups or serious coup plots, then this county suffers the lack of serious component of democratic consolidation. The behavioral dimension also includes the fact that no ethnic group is seriously working for secession in a consolidated democracy (Linz and Stepan 1996).

Democratic consolidation has normative and attitudinal features too, such as a high degree of public support for the democratic regime (even under conditions of low government effectiveness when dealing with major economic problems), internalization of democratic norms at the elite and mass public levels, broad elite consensus on the basic rules of the democratic game, and legitimation of democratic institutions (Linz and Stepan 1996, Gunther et al 1995, Pridham 2001). In addition to the behavioral and

\footnotetext{
${ }^{15}$ For a discussion on the quality of democracy; see Diamond and Morlino 2005 (eds), particularly the introductory chapter in this volume.
} 
normative dimensions, some scholars have suggested two more elements: (1) stronger civil society, and (2) protection of fundamental rights and liberties (Linz and Stepan 1996, Mainwaring et al 2000).

Overall, the attribution of various characteristics to democratic consolidation shows that it is a multidimensional and complex phenomenon. This also implies that holding elections even by free and fair means, does not guarantee consolidation. An important question in democratization studies is whether putting the threshold for democratic consolidation too high can make this concept complicated and impractical. Andreas Schedler's analysis of democratic consolidation is helpful here.

Schedler classifies political regimes into four categories: authoritarianism, electoral democracy, liberal democracy, and advanced democracy. Then, he argues that democratic consolidation basically deals with "completing democracy" (progress from electoral democracy to liberal democracy). In addition, it is related to "preventing democratic breakdown" (retreat from liberal democracy to authoritarianism) and "preventing democratic erosion" (move back from liberal democracy to electoral democracy). Moreover, he contends that democratic consolidation is basically about survival of the democratic regime rather than high quality of democratic governance $\left(\right.$ Schedler 1998) ${ }^{16}$.

\footnotetext{
${ }^{16}$ Schedler's use of 'advanced democracy' may be considered in parallel with the analysis in Diamond et al 2005 (Assessing the Quality of Democracy) where the 'quality of democracy' is related to the rule of law, vertical accountability, responsiveness, equality, participation, and horizontal accountability. Here, O'Donnell's article, "Illusions about Consolidation", underlines the difference between the formality and reality of democratic consolidation.
} 
An important characteristic of Schedler's definition is that it is neither a minimalist nor maximalist assessment of democratic consolidation. For this reason, it shapes the way the consolidation concept is conceived in this dissertation.

What is democratic consolidation in this study?

The working definition of democratic consolidation in this dissertation follows a middle ground benefiting from the works of several scholars in the literature. It takes regime survival as a key component but it also requires a considerable amount of public legitimacy and elite consensus for the democratic regime. In addition, it pays attention to whether a multi-national democratic regime faces a substantial risk of secession. Then, the dissertation holds that a consolidated democratic regime has the following four components.

1. Free, fair, competitive elections with universal suffrage; no politically significant group should be excluded from the electoral competition.

2. The protection of fundamental rights and liberties including human and minority rights

The above two conditions constitute a procedural definition of democracy. (Dahl

1971: 1-9) Meeting these conditions is essential for a democratic transition to be completed. But additionally, consolidated democracies also have the following features:

3. Higher prospects of regime survival. Consolidated democracies have civilian control of military; coups and/or severe coup plots make a democracy unconsolidated (Schedler 1998: 103-5, Huntington 1991: 231-53). In consolidated democracies, the military do not intervene in politics; they neither have tutelary powers nor reserved domains (Valenzuela 1992: 62-6, Aguero 1995: 16-7, Mainwaring et al 2000: 2-4).

4. Public legitimacy and elite consensus for the democratic regime. Democracy is the most preferable type of political regime for the majority of people; no 
politically significant group or political party works for an alternative political regime or seeks for secession (Linz and Stepan 1996: 5-7, 16-37, Higley and Gunther 1992: 3-7, Gunther et al 1995: 5-10). Anti-system parties and separatist groups with a strong public support make a democracy unconsolidated.

A middle ground position in defining the democratic consolidation has two important benefits. On the one hand, focusing only on the prospects of regime survival (minimalist definition) fails to notice the significance of legitimacy. Hence, the attitudinal dimension should not be understated. On the other hand, requiring countless numbers of conditions for a democracy to be consolidated (maximalist definitions) makes the concept less useful in the real world. For this reason, making a distinction between consolidated democracies with a low level of quality and the ones with a high level of quality could help us to understand variations across different democratic regimes.

Instead of a general, even sometimes ambiguous, concept of democratic consolidation, the four-part approach here will facilitate a systematic analysis of the democratizing impact of European integration in the consolidation processes of Spain, Poland, and Turkey.

\section{Methodology}

In order to identify the links between independent, intervening and dependent variables, the study benefits from two qualitative methods: case study and process tracing.

\section{The Case Study Method}

As one of the major types of qualitative research techniques, the case study method has various strengths. George and Bennett (2005) define it as "the detailed examination of a historical episode to develop or test historical explanations that may 
generalizable o other events" (p.4). They argue that case studies are particularly helpful to explain causal mechanism and to assess complex causal relations. For Ragin (1987), "systematic investigation of a constant reflection on a limited number of cases may lead to 'medium range' theories bound with in time and space". Overall, the case study method, Ragin contends, appreciates complexity of social life by being sensitive to human agency.

The case study method has also some weaknesses. As Gerring 2004 and George \& Bennett 2005 suggest, it might be hard to make generalization on the basis of a limited number of cases. For example, one can argue that research on Spain, Poland and Turkey cannot produce overall conclusions for other cases of European integration either from Southern or Eastern Europe. Although this is a fair criticism, an in-depth analysis of three country cases can generate many insights to understand the relative significance of European integration for other cases as well. In this regard, Ragin's concept of "multiple conjunctural causation" might be relevant. It suggests that social life involves many cases in which different combinations of causes might lead to same outcome. Such a causal heterogeneity, Ragin argues, respects complexity of social life.

Another major limitation, or challenge, for case studies is poor case selection. Case studies can be a very useful technique only if they are theoretically grounded (Ragin 1987, Peters 1998). In this regard, the research design should included sufficient justification for the selection of cases. Methodologists suggest that choosing cases on dependent variable poses an important limitation for case study methods, and they urge selecting cases on the basis of variation in the independent variable. 
The case study method may involve both within-case analysis of single cases and comparisons of a small number of cases in order to explore causal mechanism (George and Bennett 2005: 17). In this dissertation, the within-case analysis along with the process-tracing method will be employed in the case study chapters while the concluding chapter will compare the three cases on the basis of hypotheses set here.

\section{The Logic of Case Selection}

Several reasons guide the selection of Spain, Poland and Turkey for a comparative analysis in this dissertation. First, each country comes from a different wave of European enlargement, and this set of countries could facilitate assessing the evolution of EU's democratic conditionality over time. The existing literature argues that the EU imposed a stricter conditionality for the Central and Eastern European candidate countries vis-à-vis the Southern enlargement. The three-county comparison in this study will be able to examine this argument in an elaborate way. Second, the pairs of SpainTurkey and Poland-Spain have a number of important similarities that can facilitate understanding the relative salience of EU's democratizing impact for democratic consolidation processes in these countries. For example, ethnic nationalism/separatism and the military have posed substantial challenges for democratic regimes both in Spain and Turkey. In addition, democratic transitions in both Spain and Poland were "pacted transitions"17, which favored the transition and consolidation processes. Third, Spain and Poland as two success stories in the realm of democratization and European integration

\footnotetext{
${ }^{17}$ O’Donnell et al 1986, Transitions from Authoritarian Rule
} 
can offer many insights for Turkey-EU relations, which attract recurring attention in contemporary world affairs.

\section{Process-Tracing; Ascertaining Causality Within Countries}

Process-tracing method traces and compares the sequences of events, and enables structured comparisons. It maps out the links between possible causes and observed outcomes, and helps identifying causal mechanism. Process-tracing explores the links between independent, intervening, and dependent variables in a theoretical explanation. Process-tracing may take three different forms: detailed narrative, analytic explanation, and more general explanation. While analytic explanation is explicitly theory-oriented, detailed narrative may follow highly specific historical explanation without following a theoretical analysis. Moreover, process-tracing may be employed in a case study (George and Bennett 2005: 210-12, Faletti 2006)

In this dissertation, the employment of process-tracing method will be helpful to identify the links between the EU's democratizing conditionality, domestic intervening variables, and the processes of democratic consolidation. For example, process-tracing will shed light on understanding the degree to which the EU's requirement for democratic conditionality contributed to democratization and human rights reforms in Spain, Poland, and Turkey. For this purpose, official documents, newspapers, and elite statements (government officials, members of parliament, party members i.e.) will be utilized. The author's interviews with political and intellectual elites in the three countries will also be helpful. Moreover, process-tracing method will be useful in assessing the relative 
salience of EU's democratizing leverage vis-à-vis the democratic effects of non-EU international and domestic dynamics of democratic consolidation. For instance, processtracing will help exploring the democratizing impact of NATO accession process for civilian control of the army in the three countries.

\section{Data}

EU official documents (the EU Presidency Conclusions, the European Commission's annual progress reports on the candidate countries, and others)

Official documents from Spain, Poland, and Turkey (government documents and legislative records for the EU harmonization reforms i.e.)

Field study in Spain, Poland, and Turkey from June 2009 through January 2010. During the field study, the author interviewed with Members of Parliament, political party officials, academics, experts, journalists and bureaucrats. ${ }^{18}$ Of the sixty interviews, two-third of them was made in a face-to-face format while the rest of the interviewees preferred to give his/her views by responding to the twelve question interview document. The interview questions, which were also used in the face-to-face interviews, were dealt with three major issues: (i) democratizing effects of the European accession process, (ii) major problems of democracy during the accession process, and (iii) domestic dynamics of the accession process (cross-party consensus on the EU membership, i.e.). ${ }^{19}$

Newspapers.

Secondary sources: books, journal articles, and dissertations.

\footnotetext{
${ }^{18}$ See Appendix 2, 3, and 4 for the list of interviewees.

${ }^{19}$ For the interview questions, see Appendix 1.
} 


\section{Outline of the Chapters}

This introduction presented the research question, made a literature review, and then discussed issues relating to the research design: hypotheses, independent and dependent variables, methodology, and data. The second chapter first discusses international dynamics of democratization, and then delves into how the European Union has involved in the realm of democracy promotion. In addition, it examines the EU's democratizing contributions in the Southern and CEE enlargements in comparative perspective. Finally, the chapter evaluates the historical evolution of EU's democratic conditionality rule. The case studies in chapters 3,4 , and 5 examine the relative salience of European integration in the democratic consolidation processes of Spain, Poland, and Turkey respectively by means of the process-tracing method. These chapters give particular attention to the power and limits of EU's democratizing impact vis-à-vis domestic and non-EU dynamics of democratization in the three countries. The concluding chapter reviews the three case studies, and undertakes a cross-national comparative analysis of the EU's democratizing impact in the three countries. 


\section{CHAPTER II}

\section{INTERNATIONAL DYNAMICS, EUROPEAN INTEGRATION AND DEMOCRATIZATION}

The international dynamics of democratization have attracted a growing attention in recent years. Herein I review the increasing focus on international dynamics within the comparative and the international fields of political science. The first part of the chapter discusses five key issues in regard to the sources of and solutions for the causal complexity problem in this area. The second part deals with the democratizing potential of European integration. To do so, the section first examines the distinctive features of EU's democratic promotion policies. Then, it compares the EU's democratizing impacts in the Southern Enlargement (1975-86) with those in the Eastern enlargement (19942004). Finally, the chapter ends with an analysis of the historical evolution of the EU's democratic conditionality.

\section{International Dynamics of Democratization}

Democratization studies occupied an important part of the discipline of political science in the post-Second World War period. In searching for the origins of democratic transitions and stability, political scientists and sociologists came up with three major explanations in the 1950s and 1960s: (i) culture, (2) class structures, and (3) economic development. Cultural explanations emphasized the significance of democratic political culture (Almond and Verba 1963, i.e.). Class-centered explanations argued for the primacy of balances of power among different social classes (Moore 1966, i.e.). Modernization studies were mainly interested in the level of economic development. 
These works anticipated that high-income levels generate stable democratic systems (Lipset 1959, i.e.). In the following two decades, the democratization literature witnessed the rise of two additional explanations: institutions and elite dynamics. Institutional explanations have asserted the importance of political institutions for the stability of democratic regimes, while elite-centered/transitology studies have paid a close attention to the behavior of political-military elites for the democratic transitions. ${ }^{20}$

An important feature of the democratization studies in the post-war period is that international dynamics of regime change have been rarely examined. Until the mid-tolate 1980s, the field of comparative politics witnessed only a few studies that attribute importance to international factors. ${ }^{21}$ Then, the outbreak of the "third wave" of democratization in the mid-1970s became a turning point for an increasing focus on the international realm. ${ }^{22}$ Thereafter, democratization scholars have begun to incorporate international factors to explain the causes of authoritarian breakdowns and democratic transitions, which occurred in Southern Europe, Latin America, and Eastern Europe. They have discussed a variety of international factors in the analysis of the third wave democratic transitions. In their analyses, many international factors (military defeat, the collapse of the Soviet Union, American and European policies of democracy promotion, and globalization i.e.) have been complemented to the domestic dynamics of democratization (Schmitter 1986: 3-10, Whitehead 1986: 3-46, Huntington 1991: 85-100, Pridham 1994: 29-30, Remmer 1995: 105-8, Linz and Stepan 1996: 72-81).

\footnotetext{
${ }^{20}$ Huntington 1968 was a seminal work for the institutional arguments while O'Donnell and Schmitter 1986a pioneered the transitology studies.

${ }^{21}$ For example: Dahl 1971, Skocpol 1979, Collier 1979, O’Donnell and Schmitter 1986a

${ }^{22}$ The "third wave" term belongs to Samuel P.Huntington (1991).
} 
Beginning with the mid-1980s, international factors have gradually attracted a growing attention in the democratization studies. For example, O'Donnell and Schmitter (1986) give some credit to international factors, although domestic factors play a primary role in their explanation of the origins and evolution of democratic transitions (1986a, 1986b: 18). Later, many studies attributed much more importance to the external context. The increasing level of significance has been especially prevalent in examining democratic transitions in Central and Eastern Europe. In the past two decades, the question is no longer whether the international matters but under what conditions the external factors shape the processes of democratic transition and consolidation.

Although there has been an increasing focus on international dynamics, recent studies have demonstrated the existence of a causal complexity problem in this area. The problem deals with the exploration of linkages among the international phenomena, domestic dynamics, and democratization. In what follows, five key issues will be discussed to examine the sources of and the solutions to the causal complexity question. These issues have been considerably visible in recent studies on the international dynamics of democratization.

(i.) The international dynamics of democratization are composed of a very wide range of actors and processes, and that complicates identifying the relative impact of international factors vis-à-vis domestic. The literature has cited the following actors as agents of democracy promotion: states, international/regional organizations, political party internationals, transnational network of political foundations, the Catholic Church, and transnational civil society. 
On the state-level, major attention has been paid to foreign policies of the United States and the Soviet Union. In this regard, both positive and negative roles have been recognized. On the one hand, some scholars concur about in the positive impact of American interventions in the post-war democratic transitions in Germany, Italy and Japan (Dahl 1971: 192, Pridham 1991a: 23-24). In addition, the US policies of human rights and democracy promotion have been found helpful in other places such as Puerto Rico and Argentina (Whitehead 2001a: 64), Sikkink 2001: 114). On the other hand, several studies underline that strategic priorities of the US during the Cold War generated anti-democratic outcomes in many countries (Rueschemeyer et al 1992: 73, Schmitter 2001: 33).

A seminal example of the decisive role of international dynamics of democratization is the end of Soviet military veto for the CEE countries. In contrast to the Soviet veto during the heydays of the Cold War, Gorbachev's non-interference policy was taken as the key factor that made democratic transitions in the region possible (Pridham 1994: 18-19, Whitehead 2001c: 358).

International organizations have also been considered as important actors of democratization in the literature. In this regard, the EU, NATO, the Council of Europe (CE), the Organization for Security and Cooperation in Europe (OSCE), and the Organization of American States (OAS) have attracted the most attention. Several studies suggest that prospects and processes of EC/EU membership have made significant contributions to democratization in the Southern, Central and Eastern Europe (Huntington 1991: 87-91, Pridham 1994: 23-25, Linz and Stepan 1996: 140-1, Whitehead 2001b: 261, Schmitter 2001: 33, Pridham 2000: 285-314). Particularly important, 
democratic conditionality has been noted as a key dynamic behind the EU's democratizing power in the candidate countries.

Although not equal to the systematic and powerful democratizing force of the EU, many scholars of democratization agree upon the direct and indirect democratizing effects of NATO membership. In this regard, they have pointed out two positive roles: (1) help to establish a favorable international context for democratization by providing security for the CEE states in the post-Cold War era, and (2) contribute to the development of democratic civil-military relations in the Southern, Central, and Eastern European countries (Pridham 1994: 109-110, Pravda 2001: 7-10).

Furthermore, the Council of Europe and the OSCE have been examined as actors of democratization. However, neither the $\mathrm{CE}$ nor OSCE has had effective democratic conditionality. Democratizing effects are expected primarily in the aftermath of accession. Membership to these organizations has been considered as a step for EU and NATO membership (Kelley 2004a: 22). The Organization of American States (OAS) has also been analyzed whether it has had any democratizing impact on its members. Many scholars argue that OAS has made modest contributions in some cases (the 1993 democratic crisis in Guatemala, i.e.), while it has failed to influence elsewhere (Whitehead 2001d: 399-400, Pevehouse 2005: 190-2, Levitt 2006: 116-8).

An important development in the area of democratization studies has been the growing salience of transnational non-governmental organizations (NGOs) in promoting democracy, particularly in the post-Cold War period (Remmer 1995: 105, Schmitter 2001: 46, Ziolanka 2001: 515). For example, Huntington (1991) has taken prodemocratic role of the Catholic Church one of the key causes for the third wave 
transitions. Other studies emphasize the democratizing effects of transnational social movements through democracy and human rights campaigns (Keck and Sikkink 1998: 79-120, Sikkink 2005: 151-173, Khagram et al 2005: 3-23). Moreover, political foundations have been noted as agents of democracy promotion. In this regard, German political foundations (FES, KAS i.e), the Soros Foundation, and some non-profit organizations in the U.S. (Freedom House i.e.) are usually given as primary examples (Grabendorff 2001: 216-18). Finally, transnational political party networks are also found to have played a role in promoting democratic ideas and practices. Many scholars argue that European party internationals (the Socialist International, the Christian Democrat International, and the Liberal International i.e.) contribute to the diffusion of democratic norms among political party elites in the Southern, Central, and Eastern Europe (Powell 2001: 300-310, Pridham 2005: 164-8).

As seen from the above discussion, many actors (state, non-state, and IOs) have been involved in the realm of democratization. In addition, various process type and systemic international dynamics influence, to a varying extent, the democratic transition and consolidation. These dynamics include globalization, information technology, zeitgeist, demonstration/diffusion effects, and international economic crises. For some scholars, globalization and modern information technology have created a more favorable international context for democratization (Remmer 1995: 105). Moreover, others contend that zeitgeist, the hegemony of the idea of democratic regime in the current global context, has provided a favorable context as compared to the rise of fascism in the interwar years (Rupnik 2000: 116-121, Linz and Stepan 1996: 74-76, Rueschemeyer et al 1992: 74). Demonstration/diffusion effects have been referred to as a potential impact of 
democratic transition in neighbor countries. For example, the outbreak of democratic transition in Portugal in 1974 may have had some democratizing effects in Spain and Greece. Similar effects may be explored in the Central and Eastern European transitions (Schmitter 2001; 41, Linz and Stepan 1996: 76, Kubicek 2003a: 5). Moreover, international economic crises may have some role in pushing for authoritarian breakdowns. For example, one can argue that the oil shocks in the 1970s did have such an impact in Southern Europe and Latin America (Remmer 1995: 106). Finally, changes in the international political system may generate a context conducive to democratization. For example, strategic interests of the US during the Cold War did produce authoritarian outcomes in many countries while the end of the Cold War may have resulted in a more promising international context.

As suggested earlier, democratization studies have paid more attention to the international dynamics in the past few decades; yet, the existence of a wide range of international factors generates causal complexity. Although every international actor and process may not be relevant in all cases of democratization, a country may be subjective to more than one international dynamic. Then, it makes it difficult to find out the exact impact of each international factor vis-à-vis the domestic dynamics of democratization.

(ii.) The causal complexity has also stemmed from the fact that the democratization process involves many phases. Here, the literature identifies three main phases: (1) liberalization, (2) democratic transition, and (3) democratic consolidation (O’Donnell and Schmitter 1986b: 6-14, Huntington 1991, Linz and Stepan 1996: 1-6, Pridham 2000: 16-24). Although these phases sometime overlap, each has some unique aspects. In general, liberalization deals with the expansion of basic rights and freedoms. 
Democratic transition refers to the introduction of free and fair elections. Democratic consolidation involves deepening of democratic norms and institutions at the political and societal levels; then democracy becomes the "only game in town" (Di Palma 1990: 137155, Linz and Stepan 1996: 5). Keeping such multi-dimensionality in mind, the international dynamics of democratization may have varying levels of impact in different phases. For example, some studies have argued that democratizing impact of European Community was more decisive in the consolidation phase in Southern Europe in the 1980s while it did not have such a role in the transition period (Linz et al 1995: 119-120, Pridham 1991a: 14). For this reason, it is necessary to pay attention to such potential variations in assessing the impact of the international dynamics.

(iii.) The analysis of domestic-international linkages is one of the key issues dealing with the causal complexity problem. Many scholars of democratization have agreed that although the international dynamics are important, their impact has been contingent upon domestic politics (Whitehead 1991: 52, Pridham 1991b: 223, Williams 1999: 5-7, Schmitter 2001: 46-47). In other words, the international impact has been mediated through the domestic. Then, the literature has examined a wide range of domestic mediating variables that shape the democratizing impact of international factors. Such variables include, for instance, regime type (illiberal vs liberal), ethnic nationalism, cultural traditions and authoritarian leadership (Vachudova 2005: 3-5, Kelley 2004b: 428-33, Williams 1999: 16, Pravda 2001: 24-7, Kubicek 2003a: 12-20). As a result, the linkages between the international and various mediating domestic factors complicate the assessment of the degree to which the international dynamics of 
democratization matter. To understand the exact role of the international factor, then one has to explore domestic politics as well.

(iv.) The fourth key issue deals with an important observation in the literature: the impact of international dynamics varies across countries and over time. In addition, it may have varying levels of effects across policy areas related to democratization. For example, many studies argue that the international factors have generally played a more substantial role in the CEE transitions than the ones in Southern Europe (Pridham 1994: 3, Schmitter and Brouwer 1999). Moreover, as suggested earlier, the democratizing impact of the European Community appeared more visibly in the consolidation than in the transition phase of the Southern European countries. Similarly, several scholars have argued that the EU did not have much democratizing role in the early 1990s while it made significant contributions in the mid-to-late 1990s in the Central and Eastern Europe (Papadimitriou 2002: 1-6, Vachudova 2005: 3-5). The changing levels of EU commitment to the full membership goal can be suggested as an important reason for such a variation. Furthermore, domestic politics in the CEE countries may have resulted in different levels of EU impact across countries. For example, the Meciar government in Slovakia (1994-8), with authoritarian, nationalist, Euroskeptical features, delayed the beginning of accession negotiations. In contrast, the subsequent Dzurinda government undertook the EU related democratization reforms, and succeeded in opening the negotiations (Vachudova 2005: 200-2).

(v) Finally, keeping the differential impact of international factors across countries and over time in mind, it will be quite useful to have comparative studies that might involve cross-national, inter-regional or intra-regional dimensions. The 
democratization literature has witnessed some comparative studies in recent decades; nonetheless, the gap has not yet been closed. In this regard, the following type of comparative studies can be helpful: (1) the role of international factors in different regions of the world (comparisons across Southern Europe, CEE, and Latin America i.e. $)^{23},(2)$ the democratizing impact of international factors within a region across different countries, and (3) the varying international impact in one country over time.

In recent years, the fields of international relations and comparative politics have witnessed an increasing interest in the role of various international factors in the processes of democratization. As discussed above, academic studies in this area examine numerous international actors and processes in regard to the impacts on multiple dimensions of the democratization phenomenon. One should notice that such scholarly inquiry involves a high degree of causal complexity due to the presence of several independent and dependent variables. To handle such a causal complexity is not easy; nevertheless, one can better deal with the problem if two major tasks are undertaken: (1) the analysis of domestic-international linkages to assess how domestic and international factors interact with each other, and (2) making comparative studies across countries, regions, and over time. Then, one can better grasp when, how, and to what extent the international dynamics of democratization matter.

\section{European Integration and Democracy Promotion}

The democratizing potential of the European integration process has been analyzed in an increasing number of studies in recent years. These works examine a

\footnotetext{
${ }^{23}$ For example, Schmitter (1986: 4) argue that democratic transitions in Southern Europe happened in a much more favorable international context than those in Latin America.
} 
unique capacity of the European Union in making contributions to the democratization of the applicant and candidate countries. In this respect, the EU's democratic conditionality has attracted a particular attention. The following section will first discuss the particular features of European democracy promotion. Then, it will briefly compare the EU's democratizing impacts in the Southern and Eastern enlargements. Finally, the historical evolution of the EU's democratic conditionality will be assessed at a broader length.

\section{The EU and Democracy Promotion}

Many scholars of democratization and European studies have suggested that the European Union has had some unique democratizing capacity. Overall, that capacity has been different not only from the US efforts of democracy promotion but also from the democratizing impacts of other international organizations.

While comparing American and European policies of democracy promotion during the Cold War, Laurence Whitehead (1986: 8-46) notes important distinctions: American policies frequently involved the use of force, and were concerned most with electoral democracy. In addition, these policies did not much care about domestic dynamics, and were realized without clear guidelines. In contrast, European policies were based on consent not on the use of force; they occurred gradually but in a consistent manner. In general, European policies included both institutional and societal channels of influence. In the aftermath of the Cold War, such distinctive patterns continued. Overall, the US has frequently used coercion for the cause of democracy while the EU's policies have been largely based on consent and conditionality (Kubicek 2003a: 4-7). 
In terms of democratizing capacity, the EU has also been distinct from other international organizations. First of all, the EU is composed of only democratic member states, and it has taken democratic conditionality seriously as a requirement for membership. Hence, democracy has been central to the EU's enlargement strategy (Kubicek 2003b: 197). Although some other international organizations (NATO, the Council of Europe, the OSCE, the OAS i.e.) too have worked in the area of democracy promotion, they have sometimes had non-democratic members or members, which suffer from serious democracy problems. In contrast, the EU has never had non-democratic members, and it has taken democratic conditionality to an extent unmatched by other international organizations.

Second, the European Union has had a wide range of resources for democracy promotion and democratic conditionality. Basically, the EU's scale of attraction has been higher than other IOs (Pravda 2001: 7-12). As a prestigious club of wealthy and democratic states, the Union has had promising economic and political benefits for the member states. As a result, the applicant and candidate countries have had stronger incentives to join the EU (Vachudova 2005, Pridham 2006, Grabbe 2007). With combination of the strict application of democratic conditionality, that incentive structure has made the EU a major agent of democracy promotion in the world.

Third, the EU's democratizing capacity has gone a further than other IOs. The EU has employed a broad spectrum of institutional and non-institutional mechanisms. Although democratic conditionality has played a central role, the EU has also benefited from European networks of political parties and civil society. 
Institutional effects constitute an important part of the EU's democratizing impact. The prospect of accession to a prestigious democratic entity has created great incentives for the applicant countries to improve the quality of their democratic systems (Pridham 2000: 299-301). In addition, the EU has provided financial aid to candidate countries to help harmonize their legislation in line with the EU acquis. Moreover, the candidates can face suspension of aid or membership prospects if they have serious democratic crises. For example, the EC suspended the associate agreement with Greece when the military junta took over power in April 1967. In the aftermath of a military coup in September 1980, Turkey faced the same reaction (Pridham 1991b: 216, Pevehouse 2005: 141). Therefore, the membership process has included both carrots and sticks. Such institutional tools have made the EU a credible actor of democracy promotion. Sticks include the threat of suspension of financial aid or the membership process along with the EU's criticisms through annual progress reports. Carrots contain financial aid and status upgrade (beginning and completing the accession negotiations i.e.) (Kelley 2004b: 428-31, Pridham 2002: 958).

The EU's major institutional mechanism for democracy promotion has been the democratic conditionality principle. As will be discussed broadly later in this chapter, the EU's democratic conditionality evolved over time from the early 1960s to the mid-1990s. The EU has always had some form of democratic conditionality. For example, Spain's application for association agreement in 1962 was rejected because of Franco's authoritarian regime. The CEE countries experienced strict application of the democratic conditionality requirement through a meticulous overview of their democratic regimes 
(Vachudova 2005: 111-2). From the 1960s to the 2000s, democratic conditionality has been an important device for the EU's efforts to promote democracy.

The EU's democratizing power has also stemmed from several non-institutional effects. First of all, EU membership has carried a great symbolic significance for both the Southern and the CEE countries. Joining the EU has re-defined their identity in line with democratic Europe. For Spain, the accession meant the end of Franco's isolationist period. For the CEE countries, EU membership has symbolized the "return to Europe". Then, such a symbolic value of EU membership enhanced the EU's democratizing capacity. (Pridham 2000: 299) Moreover, transnational party and civil society networks in Europe complemented the EU's democratizing effects. During the course of the EU membership process, these networks have been particularly helpful in socializing politicians, businessman, and intellectuals into democratic norms. The candidate countries have had a much more favorable international context for democratization.

\section{The EU's Democratizing Impact in the Southern and the CEE Enlargements}

The literature on European Union studies has identified several similarities and differences across the two enlargement waves. In this regard, two major issues are noteworthy: (1) particular features of the Southern and CEE transitions, and (2) the EU's responses to the processes of democratization in these transitions.

When comparing democratization tasks in the CEE transitions with those in the Southern transitions, one could note several important distinctions. First of all, democratic transitions in CEE involved the task of "double transformation", which refers to transition into democracy and a market economy (Pridham 2000: 295-6, Pravda 2001: 
2-3). In contrast, the Southern enlargement cases (Spain, Portugal, and Greece) did already have market economy in the pre-transition period of authoritarian rule. ${ }^{24}$ In addition, the CEE transition cases did have to establish an autonomous state bureaucracy, which is deemed as an important component of democratic regimes (Linz and Stepan 1996: 244-53). As a result, the legacy of communism posed a distinctive challenge for democratic transitions in the CEE enlargement. Second, the CEE states began democratic transitions with lower levels of income in contrast to the Southern transitions (Whitehead 2001e: 420). Therefore, they had more urgent need for external sources of economic aid. Then, the EU's financial aid, through trade agreements and structural reform funds, was critical for the CEE states. Third, the CEE transition countries were more open to external influences than the Southern transition cases as they experienced a far deeper process of transformation (Williams 1999: 12, Grabbe 2006: 43, Borzel et al 2007: 489). Keeping all these particular features in mind, the European Union might have a greater democratizing impact in CEE.

Despite the existence of several important differences between the Southern and Eastern transitions, they have two important similarities with regard to their views on European integration. First, political elites in both regions have considered the bid for EU membership a critical enterprise not only for democratization but also for re-integration with the Western world, particularly with Europe. In other words, they have taken democratization and Europeanization as complementary processes (Pridham 1995: 179183, Grabbe and Hughes 1998: 6-9, Whitehead 2001c: 373). Second, the elite and masses

\footnotetext{
${ }^{24}$ The democratic transitions of Southern Europe might also be considered as cases of 're-democratization' since they had the experience of democratic regime earlier. The CEE transitions cases did not have such a legacy with the exception of Czechoslovakia during the inter-war years.
} 
in both the Southern and CEE countries maintained a wide support for European integration. ${ }^{25}$

In comparing the EU's democratizing impact in Southern Europe with CEE, one also has to analyze the EU's types of influences. In this regard, a few remarkable similarities and differences should be noted. First of all, the EU's impact was not decisive when the Southern and CEE democratic transitions began. In contrast, the EU made important contributions during the process of democratic consolidation. In other words, the EU's democratizing impact primarily occurred in the consolidation rather than in the transition stage (Linz et al 1995: 120). In regard to the causes of democratic transitions, domestic or non-EU international factors were more important than the EU's role. For example, military defeat in the Cyprus War (1974) against Turkey annihilated the military rule in Greece; the end of Soviet military veto made the CEE transitions possible (Pridham 1994: 8, Tsingos 2001: 346). The Southern European countries applied for EC membership a few years after the beginning of democratic transitions. Although the EU provided some financial aid in the early 1990s, there was no prospect of EU membership for the CEE countries until June 1993 (Papadimitrou 2002: 29-46). Therefore, the EU's democratizing impact was limited for both Southern and CEE democratic transitions. Domestic dynamics or non-EU international factors played more important role at this stage.

Another similarity between the two transitions occurred in respect to the limits of the EU's democratizing impact. First of all, the EU's democratizing power has been

\footnotetext{
${ }^{25}$ Although that has been a general orientation, there is also a skepticism for or resistance against EU membership in some countries. The Social democratic party in Greece (PASOK) for many years and the Meciar government in Slovakia (1994-98) can be cited as notable examples (Pridham 1995: 175, Vachudova 2005: 200).
} 
contingent upon domestic politics of the candidate countries (Williams 1999: 7-8, Kubicek 2003b: 199-200, Kelley 2004b: 431-3, Vachudova 2005: 257-9). When a Euroskeptic government is in power (the Meciar government in Slovakia, 1994-98 i.e.), the EU related democratization reforms have been stalled. Second, the EU has had limited power to prevent democratic crises (the February 1981 coup plot in Spain i.e.) in the candidate countries (Pridham 1991b: 225-226).

Although there are such important similarities between the two enlargement waves, a few important differences have been suggested. First, the CEE countries face a larger task of implementing the EU acquis ${ }^{26}$ for two major reasons: (1) communist legacies that require fundamental reforms relating to market economy and state structure, and (2) the EU acquis expanded much further in the 1980s and 1990s (Grabbe and Hughes 1998: 1-3, Whitehead 2001e: 420, Dinan 2004: 13-15, Vachudova 2005: 111). Second, the European Union required far stricter rules of democratic conditionality for the CEE states as compared to the Southern enlargement countries (Pridham 2000: 301, Grabbe 2006: 14-18). Having procedural/electoral democracy was not enough; the EU demanded the CEE candidates to have higher standards of democracy, which were set by the Copenhagen political criteria. For instance, while minority rights were not part of democratic conditionality during the Southern enlargement, the EU put them as a requirement for the CEE countries (Kelley 2004b: 427). The following section will have a broader discussion on the evolution of EU's democratic conditionality since the early 1960s.

\footnotetext{
${ }^{26}$ The EU acquis refers to the total body of EU law. The EU candidate countries have to comply with the acquis after they become a member. For more, see the $13^{\text {th }}$ footnote.
} 


\section{Historical Evolution of the EU's Democratic Conditionality}

The Treaty of Rome (March 1957), the founding treaty of the European Economic Community, did not specify whether democracy is a necessary condition for the EEC membership. ${ }^{27}$ As seen in the $237^{\text {th }}$ article ("any European State may apply to become a member of the Community"), the EEC was open to new members; nonetheless, the institution did not have any specific rules about the application process.

A few years later, the Political Affairs Committee of the European Parliamentary Assembly adopted the Birkelbach Report in December $1961^{28}$. The report primarily dealt with defining who is eligible for the EEC membership, and it set three conditions: (1) geographical (2) economic, and (3) political. The geographical prerequisite, in line with article 237 of the Rome Treaty, required that only European states could join the Community. The economic condition underlined the economic capacity of the applicant country to work with the EEC, particularly dealing with free trade and the common market. Finally, the section on political conditionality discussed issues of political character, and put political prerequisites for associate and full membership. The report included an article as follows:

${ }^{27}$ Full-text of the treaty is available at: http://europa.eu/scadplus/treaties/eec en.htm. The following link provides the treaty in pdf version: http://courses.essex.ac.uk/gv/gv546/Rome\%20Treaty.pdf

${ }^{28}$ Willi Birkelbach, a member of the European Parliament from Germany's SPD at that time, played a major role in the preparation of such a report. He also was the rapporteur of the report. Full-text of the Birkelbach Report (in French) is available at:

http://www.ena.lu/report willi birkelbach political_institutional aspects accession_association_with com munity december 1961-020006013.html 
The guarantee of the existence of a democratic form of State, within the meaning of a liberal political organization, is a condition for adhesion. States, whose governments do not have democratic legitimation and whose people take part in the decisions of government neither directly nor by freely elected representatives, cannot claim to be allowed in the circle of the people which form the European Communities. (Article 25; translated from the original language, French)

The report underlined the political character of EEC with a concern that the Community cannot be relegated into an international economic organization or an economic integration, which is devoid of political element (articles 66, 69, 87 and 88).

When Spain applied for associate membership of the EC in February 1962, the Birkelbach Report shaped the EC's decision of rejection. The authoritarian Franco regime was not considered as an eligible state for an associate status, let alone full membership. The Benelux countries, which were ruled by Social Democratic governments at that time, were particularly against Franco's application (Pridham 2005: 30). Moreover, the Spanish opposition to the Franco regime called for the EC to reject the associate application, and it demanded a democratic Spain to join the EC (Powell 1995: 23, Vidal-Beneyto 2004: 21). In this regard, the June 1962 Munich Conference, which gathered the Spanish opposition and European parties to evaluate the prospects of democratic transition in the country, was a key event influencing the decision of EC officials. Thereafter, the European Community rejected the application for associate agreement but it made a preferential trade agreement with Spain in June 1970 (McClellan 1978: 199, Powell 2001: 296).

The EC's rejection of Spain's application set an important precedent for the Community's political conditionality during the period of Southern enlargement. 
Furthermore, the European Community, in line with the democratic conditionality, froze association agreements with Greece and Turkey following the military coups in April 1967 and September 1980, respectively (Pridham 1991b: 216). These actions demonstrated that the EC did have a substantially political character, and that democratic regime is an important prerequisite even for associate membership.

A few years after the beginning of democratic transition, Greece (1974), Portugal (1974) and Spain (1975) applied for the EC membership in July 1975, March 1977, and July 1977, respectively ${ }^{29}$. As suggested earlier, the political elites in all three countries, albeit in varying degree, considered Europeanization and democratization as two complementary processes. The EC responded to the applications affirmatively but it required the survival and improvement of democracy in the applicant states. Yet, the European Community did not have any rigorous method of conditionality for the Southern transitions. For example, as many scholars suggested, Greece joined the EC in January 1981 although it had substantial deficiencies in the implementation of the EC acquis (Grabbe 2006: 144, Vachudova 2005: 111). During that time, the European Council overruled the Commission's negative opinion in which the early Greek accession could cause to serious problems in the implementation of the EC acquis (Grabbe 2007: 113). The Council expected that Greece would sufficiently align with the EC acquis after the accession. In contrast, the CEE enlargement countries have not been tolerated in such terms in their accession process.

The European Union did have a policy of democratic conditionality during the Southern enlargement but it developed a more stricter conditionality rules for the Central

29 "The Enlargement of the European Community: European File 5/79", The European Commission, March 1979 (http://aei.pitt.edu/4590/01/003956_1.pdf) 
and Eastern European countries. As suggested earlier, the EU was slow in responding to the 1989 events in the CEE. The Union established trade agreements and provided some financial aid for the CEE states in the early 1990s. In addition, the EU established associate agreements with Poland (1991), Czechoslovakia (1993), Hungary (1991), Bulgaria (1992), and Romania (1993) (Ram 1999: 434-435). Nevertheless, the EU did not provide any prospect for full membership until the June 1993 Copenhagen European Council summit. Until the historical Copenhagen summit, the Union followed a cautious and step by step approach towards the accession requests of the CEE countries (Papadimitrou 2002: 34, Pridham 2005: 35).

By explicitly confirming the prospect for full membership, the June 1993 Copenhagen European Council set conditions for the CEE. Later, the EU clarified its strategy towards the CEE enlargement in the December 1997 Luxembourg European Council meeting. The Luxembourg meeting also paved the way for opening the accession process with the six applicant countries (Grabbe and Hughes 1998: 41-43).

The Copenhagen summit was a key event in defining conditionality rules for the EU candidate countries. The Copenhagen criteria included both political and economic conditions, and asked the candidate countries to align with the EU acquis. The criteria underlined that the EU's absorption capacity is an important factor in setting the timing of accession. Conclusions of the summit included as such:

The European Council today agreed that the associated countries in Central and Eastern Europe that so desire shall become members of the European Union. Accession will take place as soon as an associated country is able to assume the obligations of membership by satisfying the economic and political conditions required. 
Membership requires that the candidate country has achieved stability of institutions guaranteeing democracy, the rule of law, human rights, and respect for and protection of minorities, the existence of a functioning of a market economy as well as the capacity to cope with competitive pressure and market forces within the Union. Membership presupposes the candidate's ability to take on the obligations of membership including adherence to the aims of political, economic and monetary union.

The Union's capacity to absorb new members while maintaining the momentum of European integration is also an important consideration in the general interest of both the Union and the candidate countries.

The European Council will continue to follow closely progress in each associated country towards fulfilling the conditions of accession to the Union and draw the appropriate conclusions. ${ }^{30}$ (p.13)

The Copenhagen meeting in June 1993 became a milestone in the pre-accession strategy of the EU towards the CEE countries. Like the Birkelbach report, the Copenhagen conditionality rules considered democratic regime as a prerequisite for the membership. Yet, the latter have gone further with the inclusion of human and minority rights. In this regard, the EU's democratic conditionality set by the Copenhagen meeting did have broader dimensions. In other words, the Union pursued a more rigorous application of the conditionality for the CEE countries vis-à-vis the Southern enlargement (Pridham 2000: 293, Pridham 2005: 35-51, Vachudova 2005: 110-2, Grabbe 2006: 4344). Therefore, the CEE states were faced with a more rigorous conditionality to join the European Union.

In applying a stricter form of democratic conditionality, the EU used several mechanisms during the CEE enlargement. Many of those mechanisms were novel as compared to the Southern enlargement. For example, the EU closely monitored the level of progress taken by the candidate countries in numerous issue areas: fundamental rights

\footnotetext{
30 "Conclusions of the Presidency", European Council in Copenhagen, 21-22 June 1993 (The full-text is available at the European Council website: http://europa.eu/european-council/index_en.htm)
} 
and freedoms, stability of democratic institutions, rule of law, judiciary, human and minority rights, corruption, effective administration, civil society, and the civil-military relations. Overall, the Union required the candidate countries to align with liberal democratic institutions and norms in the EU member states. For this purpose, the EU asked the candidate countries to align their legislation in line with the EU acquis, and demanded effective implementation. Beginning with the fall of 1998, the European Commission prepared annual progress reports for each candidate country. The reports assessed to what extent the candidate countries fulfilled the Copenhagen conditionality, and aligned with the thirty-five chapters of the EU acquis ${ }^{31}$. Although harmonization of laws for the EU acquis continued during the accession negotiations, the EU put the political criteria of Copenhagen conditionality as a prerequisite to launch the accession negotiations. In other words, a candidate country, which fails to meet the political criteria, could not move to the negotiations phase. Such a pre-accession strategy provided the EU with unprecedented power to shape democratization in the candidate countries. ${ }^{32}$

The Slovakia case is a seminal example to which the EU applied the democratic conditionality seriously in the pre-accession strategy. In the December 1997 Luxembourg European Council meeting, the EU excluded Slovakia from the countries, which were scheduled to start accession negotiations in March 1998. The Union concluded that the

\footnotetext{
${ }^{31}$ The website of the European Commission provides information about the EU acquis chapters. http://ec.europa.eu/enlargement/enlargement_process/accession_process/how_does_a country_join_the eu Inegotiations_croatia_turkey/index_en.htm\#4

${ }^{32}$ The EU's efforts to check democratic credentials and human rights record in the candidate countries were not all easy. In contrast to the economic criteria, measuring the political criteria posed an important challenge. As Grabbe 2006 and Ziolanka 2001 point out, the monitoring process involved a certain amount of subjective evaluation, and it sometimes entailed inconsistency and the lack of precision. Nevertheless, the EU demanded higher standards of democracy and human rights from the CEE countries as compared to the Southern enlargement countries.
} 
Meciar government (1994-98) failed to fulfill the Copenhagen political criteria (Grabbes and Hughes 1998: 44). At the same meeting, the EU excluded Turkey from the accession negotiation process on the basis of political and economic reasons. ${ }^{33}$ Moreover, the EU paid close attention to human rights issues in the CEE countries, and it included human and minority rights as part of the Copenhagen conditionality.

To reiterate, the EU applied a more comprehensive and tighter conditionality, including the political one, towards the CEE countries as compared to the Southern enlargement countries. The political conditionality involved areas beyond formal democracy, and it demanded higher standards of democracy (Kubicek 2003a: 21, Pridham 2005: 42; 2006: 380). The annual progress reports noted developments in the candidate countries in regard to freedom of the press, social pluralism, effective administration, corruption, protection of minorities, civil society and political parties. ${ }^{34}$ Overall, the CEE accession countries were expected to realize substantial progress in these areas before joining the EU while fulfilling the political criteria was a prerequisite to begin the accession negotiations.

What caused the application of a tighter conditionality in the Eastern enlargement? In this regard, two major reasons are notable for many scholars: (1) the CEE states, due to their communist legacies, did have substantial deficiencies regarding market economy and state structures, and (2) the EU acquis in the 1990s was far more expanded and complicated vis-à-vis the one in the 1970s \& 1980s. The acquis had

33 "Conclusions of the Presidency", European Council in Luxembourg, 12-13 December 1997 (The full-text is available at the EC website: http://europa.eu/european-council/index_en.htm) ${ }^{34}$ The annual progress reports are available at the website of European Commission:
http://ec.europa.eu/enlargement/press_corner/key-documents/index archive en.htm 
extended to common currency and economic policies, immigration, border control and foreign policy (Grabbe and Highes 1998: 1, 59-63, Vachudova 2005: 111, Dinan 2005: 15, Pridham 2005: 42, Grabbe 2006: 33-35). As a result, the CEE countries, which started with comparatively lower levels of EU acquis capacity, had to meet the expanded EU acquis tasks. Therefore, they were faced with tougher conditionality rules.

Moreover, the European Union was particularly cautious about the potential impact of the CEE enlargement on the EU's absorption capacity. As mentioned earlier, the 1993 Copenhagen criteria included the absorption capacity as a part of the conditionality rules. The extent of the CEE enlargement (ten countries) made the EU member states more cautious; and it influenced to a great extent the drive for tougher conditions. ${ }^{35}$ In the aftermath of the CEE enlargement in 2004 and $2007^{36}$, the next wave of EU candidate countries (Turkey, Croatia, and the Western Balkan countries) have faced an increasing amount of references to the 'absorption capacity'. In addition, the EU required Croatia and Serbia cooperating with the International Criminal Court for the former Yugoslavia (ICTY). For Turkey, the Cyprus conflict has become a key dynamic in shaping the pace of the accession negotiations. ${ }^{37}$ As a result, the EU develops tougher conditions for the current and potential candidate countries as compared to the CEE and the Southern enlargement countries.

\footnotetext{
35 Another important feature of the CEE enlargement is that the European Commission played a more important role in the accession process while the European Parliament was the key EC institution during the Southern enlargement (Pridham 2005: 42, Grabbe 2006: 26).

${ }^{36}$ Bulgaria and Romania joined the Union in 2007 while all other CEE countries acceded in 2004.

${ }^{37}$ In December 2006, the EU put hold on the eight of thirty-five acquis chapters because Turkey has not yet opened its ports and airports to trade from Cyprus.
} 


\section{Conclusion}

The international dynamics of democratization have attracted a growing attention after the outbreak of the third wave of democratic transitions in the mid-1970s. With the end of the Cold War and the increasing pace of globalization, the international dynamics have frequently been part of the scholarly inquiry about democratic transitions and consolidations. However, the growing attention to the international factor met a serious challenge in the literature: a high degree of causal complexity. As discussed earlier, the presence of various international actors and processes along with multiple dimensions of the democratization phenomenon make it difficult to identify the relative salience of international dynamics vis-à-vis domestic factors. In this regard, two major research tasks could be helpful: (1) the analysis of domestic-international linkages, and (2) the exercise of further comparative studies across countries, regions, and over time. Then, the literature on democratization will have a better assessment of the international dynamics of democratization.

The literature on European integration has underlined the unique democratizing power of the European Union over candidate countries. In this chapter, the EU's democratizing potential has been analyzed in the context of the Southern and the CEE enlargements. As suggested earlier, the EU did have a wide range of resources (institutional and non-institutional) to shape the democratization processes of the candidate countries. One also should note that the EU's democratizing impact was most visible in the process of democratic consolidation, not in the democratic transition. The EU did have the democratic conditionality for both the Southern and CEE accession cases. The Union had a considerable leverage for democracy promotion but this leverage 
was limited when the domestic political context in the candidate country was unfavorable. The EU's democratic conditionality rules evolved over time. Particularly important is that for various reasons discussed earlier, the Central and Eastern European states faced tougher conditions as compared to the Southern enlargement cases.

Nonetheless, the CEE countries achieved fulfillment of the conditions, and joined the European Union in 2004 and 2007.

This chapter has assessed first the increasing attention to international dynamics of democratization in recent years. Then, it has examined the EU's policy of democracy promotion, particularly in the context of democratic conditionality rule. In doing so, the chapter has also discussed major similarities and differences between the Southern and CEE enlargements. Now, the dissertation turns to the case study chapters where the EU's democratizing impact is assessed in democratic consolidation processes of Spain, Poland, and Turkey. 


\section{CHAPTER III}

\section{EUROPEAN INTEGRATION AND DEMOCRATIC CONSOLIDATION: THE CASE OF POST-FRANCO SPAIN}

European integration was one of the key dynamics of political transformation in the post-Franco Spain. The transformation went through two distinct phases: democratic transition and democratic consolidation. One of the most fascinating cases of the third wave of democratization in the late twentieth century, Spain's transition from authoritarianism to democracy occurred in a favorable international context while domestic factors were primarily responsible during the transition. The changing balance of political forces in the late Franco period made the democratic transition more likely after Franco's death. Having kept the trauma of the Civil War (1936-39) in mind, the Spanish political elite played a decisive role for the transition. The European Community (EC) and European political parties encouraged pro-democracy actors, and supported the transition; yet, their democratizing role remained secondary vis-à-vis the internal dynamics of the transition.

Only about one and a half years after the death of Franco, the Spanish people voted in a democratic election for the first time in forty-one years. Holding the elections did not result in consolidation of the young democracy. From 1977 to 1985, the reborn democracy faced six coup plots organised by hardliner officers. The decentralization of the Spanish state and the Basque separatism also put serious hurdles against the consolidation. King Juan Carlos's strong commitment to the democratic regime, tested in the 23 February 1981 coup attempt, was critical in the consolidation process. In addition to other domestic factors, Spain's accession process into the European Community made 
a significant contribution to the consolidation of democracy. Particularly notable, the critical linkage between European integration and democratic consolidation existed in the consciousness of key Spanish elite, including King Juan Carlos and Prime Minister Felipe Gonzalez (1982-1996). In the post-Franco period, European integration became an intrinsic part of the democratization process when it received overwhelming support from the King, the political parties, the business, the labor, and the Spanish people.

Anchored by the democratic conditionality, the prospect and actual EC membership set a highly favorable ground for the consolidation of Spanish democracy. The EC institutions, the EC member states, and European political parties contributed to democratization before and during the democratic transition: yet, the democratizing impact of European integration reached at an unprecedented level during the actual EC accession process (1977-1986). The EC's political conditionality required upholding the democratic regime. That was necessary not only to conduct the accession negotiations but also to maintain membership status after the accession. Nonetheless, as demonstrated in the February 1981 coup, the EC did not have a leverage to prevent democratic breakdown. In addition, the EC's democratizing impact was effective only after the Spanish public and elites provided a strong support for the membership.

This chapter will examine the degree to which Spain's democratic consolidation benefited from the European Community accession process (1977-1986). To do so, first it will briefly discuss some central aspects of Spain's democratic transition (1975-1978). Then, the chapter will assess the extent to which European integration contributed to the consolidation of Spanish democracy vis-à-vis other dynamics of the consolidation. 


\section{The Spanish Transition to Democracy: A Nuanced and Eclectic Approach}

In order to understand democratic consolidation, one needs to start with an analysis of the democratic transition. As a seminal case of the third wave of democratization, the Spanish transition has been examined extensively in several studies. ${ }^{38}$ In what follows, major dynamics of the transition from the Francoist political order to a democratic regime is discussed, along with Europe's democratizing effects received by Spain before and during the transition period.

In contrast to structural and cultural theories of democratization, dominant in the 1950s and 1960s, the elite centered approaches became highly influential in explaining the third wave democratization cases in the 1970s and 1980s. Thus, Spain's transition to democracy after the death of Franco attracted the attention of the elite oriented "transitology" scholars. ${ }^{39}$ Although "pacts" among the key political/military elites were not taken as a necessary condition for successful democratic transition, these studies focused on bargaining and negotiations between the authoritarian regime incumbents and the democratic opposition. According to the elite oriented scholarship, the Spanish transition was a highly successful case due to the critical roles played by key Spanish elites, including King Juan Carlos, the reformist Prime Minister Adolfo Suarez, the Socialist leader Felipe Gonzalez, and the Communist Party chief Santiago Carrillo. Even though compromises and moderation among the key leaders substantially shaped the Spanish transition, one cannot understate the significant role of the changing balance of

\footnotetext{
${ }^{38}$ For example; Carr and Fusi 1981, Marawall 1982, Graham 1984, Abel and Torrents 1984, Lancaster and Prevost 1985, Share 1986, Clark and Haltzel 1987, Gunther 1993, Maxwell and Spiegel 1994, Arango 1995, Linz and Stepan 1996: 87-115, Palomares 2004: 116-187, Tusell 2007: 270-328

${ }^{39}$ Leading study in this genre is the four-volume long “Transitions from Authoritarian Rule" (O’Donnell and Schmitter, Eds, 1986). Higley and Gunther (Eds, 1992) is another major work among these studies.
} 
political forces at the time of Franco's death. Critical elite choices were not the result of preferences of a few people; rather, they were largely conditioned by structural changes in the late Franco period. In addition, one should acknowledge the conciliatory role of the tragedy of the Spanish Civil War for the post-Franco period of moderation at the elite and public level. Structural factors were favorable for the democratic transition, and they largely influenced elite behavior. Yet, the transition process was not easy at all. Hardliners among the military officers, violent-extremist on the right and on the left, and the ETA terrorists raised serious obstacles against peaceful democratic change. Henceforth, the Spanish success story should not be taken for granted. The transition process can only be thoroughly understood by applying an eclectic and nuanced approach that respects both elite behavior and the structural factors in a larger historical context.

Comparing the early Franco period with the late Franco era in regard to societal foundations of the political regime, helps to understand that Spain's democratic transition occurred under favorable structural conditions. As a winning side of the Civil War, the Franco regime was based on the army, the church, the fascist party Falange, the monarchists, and the business. The republicans, including the Socialists and the Communists, were the domestic and exiled opposition to the regime. The Francoist rule controlled labor through corporatist structure in the first two decades. At that time, the Spanish economy was largely autarkic. The regime was isolated from the regional and international community until the 1953 agreements with the United States and the Vatican. Having benefited from the Cold War international context, the Franco regime overcame international isolation through the 1953 agreements, which enhanced its 
durability (Payne 1967, Arango 1995, Powell 2007: 228 ; 2009: 40-46, Tusell 2007: 108114).

From a long-term structural perspective, the roots of the Spanish transition to democracy were in many ways based on the socio-economic changes of the 1960s. Following the 1959 stabilization program, the Spanish economy experienced an unprecedented level of economic growth in the next decade. Having recorded the second best rate of economic growth among the OECD countries (about 7\% annually), GNP per capita increased from $\$ 300$ in 1960 to $\$ 3260$ ten years later. The country attracted millions of tourists from European countries, while two millions Spaniards migrated to these countries. The European Community rejected Spain's application for associate membership (1962) due to the authoritarian nature of the Franco regime: yet, the expanding socio-economic relations between Spain and the European countries resulted in liberalization of the Spanish economy and society. In addition, urbanization and secularization were other key changes in the 1960s (Marawall 1973, Gunther et al 1986, Powell 2006).

A significant development in this period of unprecedented socio-economic modernization was the revival of the labor movement. The Spanish workers undertook numerous strikes from the mid-1960s to the mid-1970s. While about 1.5 million hours were lost through strikes in 1966, that number increased to about 4.5 million in $1969,8.7$ million in 1970. Although the Franco regime responded to the labor strikes with a high level of repression, the workers intensified their resistance in the last years of the regime (Marawall 1979: 33-43, Carr and Fusi 1981). Nonetheless, the workers' opposition to the regime never amounted to a level that could cause collapse of the Franco rule. Their 
mobilization continued in the first years of the transition period (1976-77), yet the labor accepted the terms of compromise between the ruling right and the leftist opposition. As a result, workers' militant mobilization substantially declined in the years following the June 1977 elections and the September 1977 Moncloa Pact (Marawall 1982, Ben-Ami 1984, Fred-Lopez 1990).

Shifts in the positions of the business and the church were also critical components of the structural changes in the late Franco period. The Franco regime did not lose their support in an abrupt manner, and the business and the church stood in favor of a gradual democratic transition at the time of Franco's death. For the business, the Spanish economy was intrinsically in need of European markets and investments. As the rejection of the 1962 application demonstrated, Spain's membership in the EC was only possible in the aftermath of the democratic transition. Consequently, the transition received support from the Spanish business (Preston 1976: xv, Gunther et al 1986). Two important developments in the 1960s caused the church's favorable position to the democratic transition. First, the Second Vatican Council (1962-65) resulted in the rise of ideas supporting social justice and human rights, and this ideational change influenced the church in Spain. Second, secularization of the Spanish people and radicalization of the Spanish workers in this decade made the church more sensitive to developing close relations with the Spanish society. As a result, many church members supported the workers' opposition against the Franco regime. Particularly notable, the Church issued a communiqué in 1971, which not only asked a pardon for its role in the Civil War but also advocated severing all relations with the Franco regime (Cooper 1976: 73, Brassloff 
1998: 45, Tusell 2007). Therefore, the last years of the authoritarian regime witnessed a confrontation between the regime and the Catholic Church.

As will be revealed in more detail later, a few political leaders played a critical role in the smooth and peaceful democratic transition. However, elite behavior can only be understood in the context of the structural changes discussed above. The Spanish economic miracle, increasing radicalization of the workers, the business' drive for further Europeanization of the economy, and the pro-democratic evolution of the Catholic church in the late Franco period were essential components of the Spanish transition to democracy. Therefore, only an eclectic and nuanced approach, which takes into consideration both the long-term structural factors and the short-term key elite choices, can offer a thorough analysis of the democratic transition.

At the time of Franco's death in November 1975, favorable conditions existed in Spain to overcome a four-decade long authoritarian regime but the changing balance of social forces supporting democracy in the late Franco era did not guarantee a peaceful and swift transition. First of all, Francisco Franco quietly died in his bed. The opposition, be the workers, the liberal wing of the Church, the Socialists, the Communists or the Basque separatists, was not able to topple his rule. The reformist section of the Franco regime be liberal groups such as the Tacito or the Spanish business, waited the death of Franco before taking action in favor of democratic change. Second, there was no consensus between the regime moderates and the opposition about the pace of transition. While the former preferred a gradual transition to a democratic monarchy within the Francoist institutional framework (reform), the opposition asked for a complete break (ruptura) with the previous regime. The army was certainly against a ruptura mode of the 
democratic transition while the church and the business supported only a gradual transition (Garcia 1976: 44-7, Maura 1976: 47). King Juan Carlos was also a key supporter of the reformist mode of change. Table 3.1 reveals positions of key actors at the individual, domestic and international levels, by the end of Franco's rule.

\section{Table 3.1: Key Actors in the Spanish Transition}

\begin{tabular}{|c|c|c|}
\hline & $\begin{array}{c}\text { Support for } \\
\text { Authoritarian status quo }\end{array}$ & \begin{tabular}{lr}
\multicolumn{3}{c}{ Support for } \\
\multicolumn{3}{c}{ Democratic Transition } \\
\\
Reform & Ruptura \\
Monarchy & Republic
\end{tabular} \\
\hline Individual & $\begin{array}{r}\text { Franco; died in Nov } 1975 \\
\text { Carrero Blanco; hardliner PM, } \\
\text { assassinated in December } 1973 \\
\text { Arias Navarro; Franco loyalist PM } \\
1973-76 \\
\text { F. Santiago; hardliner general, } \\
\text { deputy PM, 1975-76 }\end{array}$ & $\begin{array}{r}\text { The King Juan Carlos; succeeded Franco } \\
\text { Adolfo Suarez; reformist PM 1976-1981 } \\
\text { Fernandez Miranda; president of the } \\
\text { Parliament (1976-77) } \\
\text { G. Mellado; reformist Chief of Staff and the } \\
\text { Minister of Defense (1976-81) } \\
\text { Cardinal Tarancon, the head of Catholic } \\
\text { Church, 1971-83 } \\
\text { F. Gonzalez, PSOE } \\
\text { S. Carillo, PCE }\end{array}$ \\
\hline Domestic & $\begin{array}{r}\text { Hardliner Military Officers } \\
\text { Falange } \\
\text { Extreme Right }\end{array}$ & $\begin{array}{l}\text { Church } \\
\text { Business } \\
\text { Regime Moderates }\end{array}$ \\
\hline International $^{40}$ & & \\
\hline
\end{tabular}

\footnotetext{
${ }^{40}$ The United States was cautious at the time of Franco's death; concerned primarily with its strategic interests (preservation of the military agreement in particular). The Franco loyalist PM Arias received more support than the reformist PM Suarez during the transition. In addition, the legalization of the Communist Party, a key step in the transition, was not much desired by the U.S. In regard to the 23 February 1981 coup attempt, the Secretary of State Alexander Haig said that it was Spain's "internal affair" (Maxwell 1991: 7, Tusell 2007: 315, Cercas 2011: 62, and the author's interview with Charles Powell).
} 
In the context of structural changes in the late-Franco period, Spain's transition to democracy was not unexpected after the dictator's death but the pace and mode of transition was marked by uncertainty. King Juan Carlos, succeeding Franco as head of state, expressed his vision of a democratic and European Spain in his coronation speech. The monarch's vision was in parallel with the majority of Spanish people. Yet, the military -one of the key pillars of the Franco regime- was certainly against a ruptura mode of transition. The ruptura mode was a choice of the regime's opposition, the Socialists and the Communists. An influential group of hardliner officers, as will be seen in several coup attempts in the following years, worked for continuity of the authoritarian regime. For the conservative majority in the army, the King, chosen by Franco as the next head of State, was the key figure for the direction of post-Franco Spain. Finding himself among these different positions, Juan Carlos had to deal with a very delicate process of political change. His preference to work with Arias Navarro, the prime minister when Franco died, reflects his caution. Arias Navarro, who had a deep loyalty to Franco, failed to realize the political reforms necessary for the democratic transition. While his failure satisfied the conservative forces ("bunker") of the Francoist structure, it disappointed the democratic opposition. Arias's stubborn posture also threatened the legitimacy of Juan Carlos for the opposition and a large segment of the Spanish people. Then, the King dismissed him and appointed Adolfo Suarez as the new prime minister in July 1976 (Coverdale 1979: 143-4, Marawall 1982: 150, Powell 1996: 93).

Having worked in the Arias's cabinet as Secretary of National Movimiento (a key Francoist institution), Suarez's appointment initially disappointed the democratic opposition. With considerable political skill and the King's support, Suarez undertook the 
political reforms necessary for the democratic transition in less than a year. His

leadership skill was most visible in maintaining a delicate balance in his relations with the opposition and the military (Lancaster and Prewst 1985: 101).

Suarez's success to move the democratic opposition accept a compromise on the model of democratic transition was certainly related to the fact that the Spanish military was clearly against the ruptura mode. Let alone the mode, an influential number of senior military officials stood against the reform mode. General F. Santiago y Diaz resigned from his post of deputy PM in September 1976 with a protest to the Law of Political Reform. The Law terminated the Francoist Cortes in order to establish a democratically elected parliament. Later, General Santiago involved in the September 1977 coup plot, known as the Jativa conspiracy. Furthermore, Admiral Pita de Veiga, the Navy Minister in the Suarez Cabinet, resigned following the legalization of the Communist Party in April 1977. Then, the democratic opposition came into the reform compromise not solely because of Suarez's leadership skill. The military, particularly the prospect of a reactionary coup, enhanced Suarez's bargaining power vis-à-vis the opposition.

Strong support for the democratic transition by the Spanish people, as demonstrated in the December 1976 referendum for the Law of Political Reform (94\% yes, $2.6 \%$ no, with $78 \%$ turnout), was a key element in Suarez's success. As suggested earlier, the changing balance of social forces in favor of democratic change in the late Franco period certainly made the transition more likely, despite the fact the Spanish military, particularly the hardliners, raised serious hurdles in the transition process. Neither violence by the extreme right and the extreme left nor the Basque separatists were able to halt the process (Story 1977: 485, Preston 1979, Powell 1996: 159). 
Following the enactment of a new electoral law in March, and the legalization of the trade unions and the Communist Party in April, the reformist Suarez government set the first democratic elections after forty-one years for June 15, 1977. With a 79\% voter turnout, the Spanish people preferred the center-right (Suarez's UCD, 34\%) and the center-left (the Socialist PSOE, 29\%) parties, while the neo-Francoist AP (\%8) and the Communist PCE (\%9) largely failed in the founding elections.

The June 15, 1977 elections signified a critical point in which Spain's democratic transition took a major step. Following O'Donnell and Schmitter's definition of democratic transition, "the installation of some form of democracy", one can argue that the Spanish transition was complete with the free-fair-competitive elections of June $15{ }^{41}$ The reborn Spanish democracy still lacked a democratic constitution protecting citizen's basic rights and liberties until the enactment of December 1978 constitution. For this reason, it is possible to extend the end of the transition era up to that time. ${ }^{42}$

Domestic factors were primarily responsible for the evolution of Spain's democratic transition. Influenced and constrained by structural changes of the late Franco period, a few representatives of the Spanish elite played critical roles. The King's firm commitment to democracy was most visible in his strong support of Suarez's reformist stand. In addition, Juan Carlos, who was the successor to Franco and the commander in chief, was the key person to deal with the army's resistance to the transition. The reformist General and the deputy PM Gutierrez Mellado also played important roles in

\footnotetext{
${ }^{41}$ O'Donnell and Schmitter 1986, Tentative Conclusions about Uncertain Democracies, p. 6

${ }^{42}$ In regard to the timing of Spanish transition, there are two major views in the literature. While some scholars take the period of 1975-78, from the death of Franco to the referendum of 1978 constitution, as the period of transition (Share and Mainwaring 1984, Huntington 1991), others extend it until PSOE's victory in the October 1982 elections (Diaz-Ambrona 1984, Preston 1986, Clark and Heltzel 1987, Story and Pollack 1991, Tusell 2007, Serra 2010).
} 
depoliticizing the army. Adolfo Suarez succeeded to bring the democratic opposition into the terms of reform mode of transition. In the process of passing the Law of Political Reform, the Cortes President F. Miranda was very helpful in convincing the incumbent Cortes members. On the opposition side, Felipe Gonzalez and Santiago Carrillo, the leaders of the Socialist and the Communist parties, forcefully demanded democratic transition but they were prudent enough not to antagonize the military. The memory of the Civil War was an important driving force behind their cautious behavior. ${ }^{43}$ Finally, Cardinal Tarancon, the head of the Spanish Catholic Church, raised his voice in support of the democratic transition.

In contrast to the 1930s in which the Spanish democracy failed, the international context of the 1970s was in many ways favorable for the democratic transition. While the 1953 agreements with the United States and the Vatican contributed to the durability of the Franco regime, the easing tension of the Cold War made the United States, at most, neutral for the transition at the time of Franco's death. Following ideational changes at the Second Vatican Council, the Vatican was mostly supportive of democratic change. Particularly important, Spain's European neighborhood contributed significantly before and during the transition process. The rapid economic development and modernization of the 1960s were to a large extent related to the country's increasing relations with Europe. Socioeconomic relations with European countries indirectly contributed to the structural changes which made the democratic transition more likely after Franco. Moreover, the European Community's rejection of Spain's 1962 application for associate membership, not only helped the de-legitimization of the Franco regime, but also increased the

${ }^{43}$ Interview with Charles Powell in Madrid on June 29.2009. For the list of interviewees and their positions; see Appendix 1. 
symbolic value of EC membership for the Spanish people, the democratic opposition, and the reformist section of the Franco establishment. In addition, European political parties and political party internationals (the Socialist International i.e.) provided organizational, financial and moral support to the Spanish opposition. ${ }^{44}$ Yet, the democratizing effects from Europe in the late Franco period were not enough to end the authoritarian regime. The Spanish transition set into motion only after the death of Franco.

\section{The Consolidation Process and the Democratic Impact of European Integration}

Spain's transition to democracy following the death of Franco was swift. The Francoist political establishment collapsed, and the democratic institutional order set up in one and a half years. The June 1977 elections and the December 1978 constitutional referendum were the landmark events for the completion of the democratic transition; however, the reborn democracy in Spain was nascent and fragile in late 1978. Coup plots by hardliners among the military, violence from the extreme right and left, ETA terrorism, and process of decentralization posed substantial challenges. The February 1981 coup attempt showed again that the Spanish democracy had yet to be consolidated. It was only around the mid-1980s that post-Franco Spain achieved democratic consolidation. In this process, European integration played a crucial role in addition to some domestic developments. In particular, the parallel and interdependent nature of the two processes-European integration and democratic consolidation- enhanced success.

${ }^{44}$ Interview with Jose Manuel Fernandez, 7.9.2009 
The EC as well as various European political parties and interest groups/NGOs, helped the Spanish democracy in several areas.

In what follows, the democratizing impact of European integration will be discussed on the basis of the middle ground definition of democratic consolidation. As discussed earlier broadly (Chapter 1: 15-18), this dissertation has a four-part definition of the consolidation.

1. Free, fair, competitive elections with universal suffrage; no politically significant group should be excluded from the electoral competition.

2. The protection of fundamental rights and liberties including human and minority rights

3. Higher prospects of regime survival. Consolidated democracies have civilian control of military; coups and/or severe coup plots make a democracy unconsolidated (Schedler 1998: 103-5, Huntington 1991: 231-53). In consolidated democracies, the military do not intervene in politics; they neither have tutelary powers nor reserved domains (Valenzuela 1992: 62-6, Aguero 1995: 16-7, Mainwaring et al 2000: 2-4).

4. Public legitimacy and elite consensus for the democratic regime. Democracy is the most preferable type of political regime for the majority of people; no politically significant group or political party works for an alternative political regime or seeks for secession (Linz and Stepan 1996: 5-7, 16-37, Higley and Gunther 1992: 3-7, Gunther et al 1995: 5-10). Anti-system parties and separatist groups with a strong public support make a democracy unconsolidated.

The following section will examine the degree to which particular dimensions of Spain's democratic consolidation benefited from the integration process vis-à-vis domestic factors. After assessing particular contributions to different aspects of the consolidation, an overall analysis will be made. 


\section{Free, fair, competitive elections with universal suffrage; no politically significant group should be excluded from electoral competition.}

The first two components of democratic consolidation are also preconditions for a democratic transition to be completed. In the Spanish case, the transition process involved the period from the death of Franco in November 1975 to the approval of democratic constitution in December 1978. Following the referendum of the Law for Political Reform in December 1976, Spaniards participated in the June 1977 parliamentary elections, and then they overwhelmingly supported the constitution ( $88 \%$ yes, $8 \%$ no with $67 \%$ turnout) in December 1978 . The elections were free and fair; no politically significant group was excluded from the electoral competition. Although the legalization of the Communist Party (PCE) created an anxiety within the army, Suarez managed to include the PCE in the elections and in the constitution-making process.

Although domestic circumstances played a primary role in the transition process, the European Community and European political parties closely observed the process, and provided their support in favor of a swift democratic change. The European Community made Spain's membership conditional upon progress in the democratic transition. As the Spanish people and political elites strongly desired European integration for their country, the EC's democratic conditionality generated an effective incentive for further democratization.

In the pre-transition period, the Socialists and the Communists were active supporters of democratic Spain's integration to the European Community. They followed a similar position after the death of Franco. The cause of Europeanization/Europeanism found support beyond the Spanish left. In parallel with an overwhelming majority of 
Spanish people, liberals/reformists in the Francoist establishment opted for European integration in the transition period. As a result, the Arias and Suarez governments, representing the Spanish right, supported the EC membership goal. All major economic interest groups including the business, labor unions and farmers, were also in favor of EC membership. Finally, the cause of European integration found support from the Catalans and the Basque people. Although different political, economic and regional groups had varying conceptions of Europe/EC, all were united for European integration. Only the extreme-right and the extreme-left forces, marginal in numbers, were against EC membership (Tsoukalis 1981:123, Holmes 1983: 178, Arango 1995:253-4, AlvarezMiranda 1996:206-14, McLennan 2000:154-59). Overwhelming support for European integration across different parties and regions made the EC accession a positive factor for the acceleration of transition reforms including the enactment of the first democratic elections.

In the transition period, the EC institutions and European political parties contributed to the conduct of free, fair, and competitive elections. For example, the European Parliament provided an enthusiastic support for the legalization of Communist Party in April 1977 through a resolution (Powell 2009: 48-51). The parliament also sent informal observers for the June 1977 elections, and accepted the elections as free and democratic. However, the European institutions including the parliament did not have any major role in the supervision of the 1977 and the subsequent elections. ${ }^{45}$ Moreover, the Spanish political parties, both the left and the right, received significant sources of support (financial, logistic, organizational, expertise, moral i.e.) from

\footnotetext{
${ }^{45}$ Online communication with Professor Charles Powell, who is the director of Fundacion Transicion Espanola (October 16, 2011). The author made an interview with him in Madrid on June 29, 2009.
} 
European political parties and political party internationals. Particularly notable, the Socialist International (SI) and the German SPD played significant roles in the formation of PSOE as a powerful opposition party in the 1977 elections. Faced with a competition between two wings of the Socialist Party, the SI and the SPD supported the reformist wing (led by Felipe Gonzalez) in the party's congress in December 1976 (Anaya 2002: $178-9){ }^{46}$

European integration received a high level of support from Spaniards and the Spanish elite in the post-Franco period. The author's interviews with current and former members of parliament, academicians, and people from political parties, the bureaucracy, and think tank organizations in Madrid in June and July 2009 confirmed this cross-party consensus on the European cause. ${ }^{47}$ The EC established a clear link between the formation of a democratic regime and the Spanish bid for EC membership. Spain applied for full membership a few weeks after the June 1977 elections. The democratizing effects came mainly from the EC institutions and European political parties.

Furthermore, the Council of Europe (CE) too was helpful during the Spanish transition. The Council closely observed the transition process. For example, the Council's Parliamentary Assembly adapted a text (September 1976), which linked Spain's C.E. membership to progress in the transition reforms. The text asked for the legalization of trade unions and political parties, and demanded a general amnesty (Pereira/ENA Paper). In addition, the Council did have a close dialog with the democratic opposition. Like the European Community, the Council of Europe demonstrated its anxiety to the stubborn Arias government, and supported the reformist Suarez

\footnotetext{
${ }^{47}$ The interviewees in Spain are listed in Appendix 2.
} 
government. For the June 1977 elections, the Council sent informal observers and endorsed the outcome. ${ }^{48}$

Spain applied for the EC membership six weeks after the June 1977 elections. For the first component of democratic consolidation-free, fair, and competitive elections-, the EC's democratic conditionality played an anchor role in the process of democratic consolidation. The Spanish political parties continued to have close links with the European parties and the party internationals in the years of EC accession process. These links were helpful for reinforcement of democratic norms in the new-born Spanish democracy.

\section{Protection of fundamental rights and liberties, including human and minority rights.}

The Law for Political Reform (December 1976) and the Moncloa Pact (October 1977) brought changes in the area of political rights and the penal code. Yet, Spain's nascent democracy did not have any basic document limiting the state and protecting the individual until the 1978 Constitution (Bonime-Blanc 1987: 13-4). With the democratic constitution, the Spanish democracy acquired the major legal basis for the protection of citizen rights and liberties. ${ }^{49}$

The first part of the constitution (articles 10 through 55) documents basic rights and freedoms. It gives leverage to the Universal Declaration of Human Rights and other

\footnotetext{
${ }^{48}$ Online communication with Charles Powell

${ }^{49}$ The Spanish Constitution is available at: http://www.legislationline.org/download/action/download/id/2325/file/Spain_Const_1978_eng.pdf
} 
international treaties in the area of human rights. ${ }^{50}$ The constitution has several liberal features such as the abolition of the death penalty (except in war time) and the right of conscientious objection (articles 15 and 30). In addition, it allows individuals to appeal to the Constitutional Court for protection of basic rights and liberties (article 53).

With the enactment of the 1978 Constitution, the Spanish democracy took a decisive step in the area of fundamental rights and freedoms. In only three years after the death of Franco, Spain moved from 5 (partly free) to 2 (free) on the Freedom House's political rights and civil liberties scale. The following table gives Spain's standing in the Freedom House's scale for the years of 1975-1986.

Table 3.2: Political Rights (PR) and Civil Liberties (CL) Scale in Spain (1975-1986)

\begin{tabular}{|r|r|r|r|r|r|r|r|r|r|r|r|}
\hline 1975 & 1976 & 1977 & 1978 & 1979 & 1980 & 1981 & 1982 & 1983 & 1984 & 1985 & 1986 \\
\hline 5 & 4 & 2.5 & 2 & 2 & 2.5 & 1.5 & 1.5 & 1.5 & 1.5 & 1.5 & 1.5 \\
\hline
\end{tabular}

Note: Average of the PR and CL scores (1 to 7; 1 most free, 7 least free)

Source: The Freedom House

With regard to the second component of democratic consolidation (the protection of basic rights and freedoms), post-Franco Spain benefited from European actors and dynamics. First of all, the European Community membership symbolized democracy and

\footnotetext{
${ }^{50}$ Spain signed the European Convention for the Protection of Human Rights and Fundamental Freedoms (ECHR) on June 30, 1981 (Ozcer 2006: 132). The Spanish desire to sign the convention existed well before this date. As a condition to join the Council of Europe, representatives of the Spanish political parties in the Parliament, signed a declaration in respect of CE ideals including human rights, rule of law and fundamental freedoms on October 8, 1977. Then, Spain joined the Council of Europe on November 24, 1977 (Pereira/ENA Paper).
} 
human rights for the Spanish people and political elite. ${ }^{51}$ The EC's democratic conditionality was a key part of this symbolism. The European Council of Ministers' Copenhagen Declaration in April 1978 stated that "respect for and maintenance of representative democracy and human rights in each member state are essential elements of the membership of the European Community". In addition, the Council of Europe asked for compliance with CE ideals including human rights, rule of law, and fundamental freedoms to be able to join the Council. In preparation of the 1978 constitution, the Spanish political elite largely emulated the European constitutional systems which are based on recognition of fundamental freedoms and human rights. In particular, the German constitution did have a considerable level of influence over the Spanish elite (Echavarria 2000: 119-21). ${ }^{52}$ In this process, European political parties were also helpful for their Spanish counterparts while the constitution-making process was primarily driven by consensus and compromises among the Spanish political leaders. ${ }^{53}$ At the time of Spain's application for the EC membership, the Community neither put the new democratic constitution as a requirement for launching the accession negotiations nor did it involve in the constitution-making process. After about a year long screening process, the European Commission reached a favorable opinion on the Spanish application in November 1978. It concluded that Spain had satisfied the political conditionality by "restoring a pluralist democracy, providing guarantees for individual

\footnotetext{
${ }^{51}$ Interview with Enrique Curiel, 6.12.2009.

${ }^{52}$ Online communication and interview with Knut Roder, who is a professor of political science in St Louis University, Madrid Campus on May 27, 2008 and June 15, 2009 respectively.

${ }^{53}$ Before the constitutional referendum, the Spanish Parliament ratified the constitution with an overwhelming majority on October 31, 1978 (Votes: 325 yes, 6 no, 14 abstentions). The referendum was held on December 6 . Results: $88 \%$ yes, $8 \%$ no with $67 \%$ turnout.
} 
liberties, and the emergence of new constitution". ${ }^{54}$ Then, the European Community opened accession negotiations with Spain in February 1979. Therefore, Spain had the second component of democratic consolidation in place largely before the EC accession negotiations were set in motion. Yet, the EC's democratic conditionality anchored the protection of fundamental rights and freedoms as it did for the maintenance of free, fair, and competitive elections.

\section{High prospects of regime survival and civilian control of the military}

A major challenge against the transition and consolidation processes in postFranco Spain came from the military. From 1814 to 1936, the country witnessed fiftyfour attempts (twelve of them successful) by the military officers to overthrow the existing government (Graham 1984: 190). With such a history one would expect that a significant part of Spain's democratization after Franco was to keep the army in the barracks. From September 1977 to June 1985, the Spanish political scene witnessed six coup plots. In the most critical one, the reborn Spanish democracy faced a serious risk of breakdown on February 23, 1981 (referred to as the 23F in Spain). The King's strong commitment to the democratic regime and the unanimous democratic reaction by the Spanish political parties and people not only led to the failure of the coup but also accelerated the consolidation process of Spanish democracy. In this realm, comprehensive military reforms made by the first PSOE government (1982-86) paved the way for democratic control of armed forces to the extent that consolidated democracies can have.

\footnotetext{
${ }^{54}$ The European Commission, "Opinion on Spain's Application for Membership ", Bulletin of the European Communities, Supplement 9/78, pages 9-10
} 
In the third component of democratic consolidation, domestic forces played a primary role but direct and indirect effects of the EC integration process were also helpful. The King's role in the $23 \mathrm{~F}$ along with his critical role in reforming the military was decisive. The Spanish political elite and people were all united against the reactionary coup. Long years of isolation and authoritarian rule and massive socioeconomic changes taking place in the late 1950s, made a democratic and European Spain a unanimous goal for the overwhelming majority of the Spanish people. In the context of such important domestic dynamics, the EC's democratic conditionality posed an extra incentive to reinforce the democratic regime. For this reason, one should not be surprised by the link, which the key Spanish elite, including the King and Prime Minister Felipe Gonzalez, established between the processes of European integration and democratic consolidation (Tavias 1984: 163, Lieberman 1985: 43, Share 1989: 50-51, Huntington 1991: 191-3). Despite such a reinforcing impact, the 23F demonstrated that the EC did not have any power to prevent a severe risk of democratic breakdown.

In the following section I discuss major issues and developments dealing with the third component of democratic consolidation in the post-Franco Spain. The discussion will end with an assessment of the extent to which European integration was helpful for Spanish democracy.

The Spanish military consisted of three major groups by the time of Franco's death: (1) the military hardliners (2) the conservatives (3) the liberals/reformists. The conservatives, open to gradual change even if grudgingly, constituted the majority. The military hardliners, although fewer in numbers, were powerful enough to attempt six 
coups between 1977 and 1985. The reformists remained a minority and most of them were expelled from the military (Medhurst 1978: 50-56, Lopez 1998: 49, Serra 2010: 93).

The military (particularly hardliner generals) was a key challenge in both the transition and consolidation processes. As a reaction to the legalization of the trade unions and the Communist Party, two senior generals resigned from their ministerial posts. ${ }^{55}$ One of them, General Santiago, played an active role in the Jativa conspiracy in September 1977. The conspiracy involved a letter to the King to reverse the transition process and establish a government of national salvation (Payne 1985: 96, Preston 1986: 129, McLauren 2008: 205). One year later, and a few weeks before the constitutional referendum, the military hardliners came up with a more serious coup plot to be launched on November 17, 1978. The plot (Operation Galaxia) aimed at halting the transition process by seizure of the Suarez government while the King was visiting Latin America. ${ }^{56}$ About one year later, the October 21, 1979 coup plot erupted a few days before the referendums on the Basque and Catalan autonomy (Preston 2004: 424, 438).

The legalization of the Communist Party, the increasing acts of violence by the ETA, and the decentralization process (the December 1978 constitutional and the October 1979 autonomy referendums, all milestone events) made the military hardliners even more anxious, and paved the way for further coup plots. In addition, in many instances, the hardliners showed disrespect for the King and the pro-democratic/reformist Gutierrez

\footnotetext{
${ }^{55}$ General Fernando de Santiago y Diaz who was the Vice Prime Minister responsible for the defense under the first Suarez government resigned in September 1976 when Suarez decided to legalize trade unions as a part of the Law of Political Reform. The Navy Minister Admiral Pita de Veiga resigned following the legalization of the Communist Party in April 1977.

${ }^{56}$ One of the plotters of the Operation Galaxia, Colonel Antonio Tejero was sentenced for seven months because of his involvement in the November 1978 coup plot. A few years later, Tejero took over the Spanish Parliament on February 23, 1981.
} 
Mellado, who served as the Chief of General Staff and the Minister of Defense from 1976 to 1981 (Vilanova 1983: 157-8, Preston 1986: 147).

In these critical years of political transformation, General Mellado made two decisive contributions to Spanish democracy. First, he endeavored to keep the military out of politics in order to prevent the peril of military intervention. Second, he played an active role in several reforms dealing with the army's depoliticization, modernization and professionalization (Graham 1984: 1, Clark and Heltzel 1987: 87). The Law of Political Reform (1976) and the 1978 Constitution eliminated several senior officers from high administrative and advisory posts in the civilian bureaucracy. The Royal Decree of early 1977 forbade the participation of military officers in political parties and trade unions. In the same year, three separate military ministers were fused into a single ministry, and the ministry of defense was created. In December 1978, a new police law ruled out the jurisdiction of military tribunals outside the armed forces. Moreover, Mellado replaced several hardliner officers with loyal ones (Payne 1986: 183, Preston 1990: 192, Serra 2010: 103-128). All these legislative and staff changes helped to curb the military's involvement in the civilian sphere.

With regard to the civilian control of the military during Spain's transition and consolidation, King Juan Carlos's role cannot be understated. The King, the legitimate successor to Franco, stood firm for the cause of democracy. Navigating between Franco's military and democratic aspirations of the Spanish society, he achieved to keep the newborn democracy on the right path. ${ }^{57}$ The King's backward legitimacy (chosen by Franco as the next head of state) provided him a high level of leverage over the military.

\footnotetext{
${ }^{57}$ Interview with Enrique Curiel.
} 
In his speeches addressing the military, he emphasized national unity, military discipline, and superiority of the Parliament. The King also attempted to assuage the military's sensibilities regarding the transition process and the ETA terrorism. (Powell 1996: 13956, Preston 2004: 377) Moreover, he supported the pro-democratic Mellado in his efforts to depoliticize and professionalize the army. In parallel with Mellado's staff replacements, Juan Carlos gradually removed hardliner generals from the military. ${ }^{58}$ For instance, he replaced senior generals at the Joint Chiefs of Staff (JUJEM) in January 1982. His contributions to the democratic civilian-military relations continued with his support for the far-reaching military reforms under the PSOE rule (Serra 2010: 157).

The February 23, 1981 coup attempt became a phenomenal event in the postFranco era of Spanish democratization. In Madrid, Colonel Antonio Tejero took over the Spanish parliament with about two hundred military officers at around 6.30pm. (Citation) While Tejero stormed the parliament, hardliner general Milans del Bosch ordered tanks into the streets and decreed a state of emergency in Valencia. The coup failed when Juan Carlos stood firm behind the democratic regime. In a few hours after Tejero's attack on the parliament, the King contacted with major generals in different regions, and asked their support for the democratic order. The generals' loyalty to the King led them not to have a position in favor of the coup attempt. ${ }^{59}$ Juan Carlos also created a new civilian cabinet while the Parliament was under attack. ${ }^{60}$ All these efforts demonstrated the King's commitment to democracy.

\footnotetext{
${ }^{58}$ Interview with Jose M. Fernandez.

${ }^{59}$ Interview with Ignocio Molina and J.M. Fernandez.

${ }^{60}$ Interview with C. Powell.
} 


\section{$\underline{\text { A Conceptual Discussion on the Civil-Military Relations in Spain }}$}

Narcis Serra, who served as a defense minister (1982-1991) in the critical period of consolidation process, proposes a three dimensional theory of democratic military reform and applies it to the transition and consolidation processes in his new book. The dimensions include: (i) conflict level axis-the degree to which civilians and military have conflict with each other, (ii) control of the military axis- ranging from full military control of politics to full civilian control of the military, and (iii) professionalism axisthe army as an institution or an occupation. Then, he argues that consolidated democracies are distinct by (i) low levels of conflict between civilians and the military, (ii) full civilian control of military, and (iii) high degree of professionalism (2010: 61-5).

According to him, one of the key distinctions between the transition and consolidation processes in the area of civilian military relations is that the military frequently intervenes in politics in the transition while the elected government creates and controls military and defense policies in the consolidation (Serra 2010: 77). This conceptualization goes in parallel with Felipe Aguero's definition of civilian supremacy: "the ability of a civilian, democratically elected government to conduct general policy without interference from the military, to define the goals and general organization of national defense, to formulate defense policy, and to monitor the implementation of military policy" (Aguero 1995: 19).

Serra and Aguero's works could be very helpful to assess when the Spanish democracy consolidated in the area of the civilian control of military. Serra's ministerial position (Defense) in this period gives an important leverage to his conceptual analysis. He argued that "the civil powers did not control the armed forces in any real sense until 
the mid-1980s" (Serra 2010: 141). Then, he examines the military reforms made through the UCD and PSOE governments from 1976 to the late 1980s. Noting that the post-1986 reforms mostly dealt with the army's professionalization and NATO membership, Serra underlines the significance of pre-1986 reforms for the consolidation process. Without denying military reforms, which were undertook by Mellado and the UCD governments (1977-1982), he further reiterates the importance of the single power majority PSOE government (1982-86) for the increasing pace of reforms (Serra 2010: 148-152, 171).

The far-reaching reforms of the 1982-1986 period made significant contributions to the consolidation of Spanish democracy. In January 1984, the new defense law (LODNOM 84) assigned to the civilian authorities (prime minister and minister of defense) a leadership role in the making of defense and military policies. The new law has also made the Joint Chiefs of Staff and the National Defense Commission only an advisory body for the prime minister and the minister of defense. A few months later, the PSOE government initiated a massive program of military modernization (META). The modernization program planned to reduce the size of the army, to make it more professional, and to transform the promotion system from seniority to meritocracy. Furthermore, reforms in the military justice system in 1985 and 1986 resulted in the strict limitation of military jurisdiction to technical and professional matters. Of particular importance is that political crimes by the military and the crimes of rebellion were assigned for processing to the civilian courts (Share 1986b: 186-94, Serra 2010: 156-72). All these reforms increased the power of civilian authorities vis-à-vis the military, and contributed to the democratic control of armed forces. Reflecting the increasing level of civilian supremacy in this period, the PSOE government dismissed top level military 
officers from their posts when they made public statements about political issues. Political statements by the military were so rare and nearly disappeared after 1987 (Serra 2010: 196-7).

With regard to the third component of democratic consolidation -high prospects of regime survival/the civilian control of military- we can say that Spanish democracy was consolidated around the mid-1980s. Although a number of scholars pointed to the failed 23F or the October 1982 elections as the moments of consolidation, the October 1982 and June 1985 coup plots were evidence of the need for further progress. The military reforms under PSOE rule paved the way for the full civilian control of the armed forces around the mid-1980s.

For this dimension of consolidation, European integration involved some contributions; however, Spain's domestic dynamics were of primary importance. The King's democratic credentials, demonstrated in the $23 \mathrm{~F}$ and in his support to the military reforms, along with the civilian unity against a reactionary coup were significant elements. In addition, the strong PSOE government, which received $47 \%$ of votes in the October 1982 elections, was determined to realize the military reforms without antagonizing the Spanish military.

The European Community made an immediate response to the $23 \mathrm{~F}$ in favor of the democratic regime. After the coup attempt, the vice-president of the EC Commission made a statement that non non-democratic country could join the EC. The Commission also reiterated the need to speed up the accession negotiations by underlining the EU's responsibility for the maintenance of Spain's democracy. Moreover, the European Parliament adopted a resolution that condemned the coup plot, and congratulated the 
King and Spanish people in favor of democracy (Pridham 1991b: 235, MacLennan 2000: 167). Therefore, the EC's condemnation of the coup and endorsement of the King for his firm standing against the plotters enhanced the legitimacy of democratic regime in the country. Moreover, the 23F also generated different reactions in France and Germany. While France used it later to slow down the accession process, Germany considered the coup as major evidence requiring the acceleration of the accession process. ${ }^{61}$ In the aftermath of the $23 \mathrm{~F}$, the Spanish government speeded up its drive for the EC and the NATO membership for the sake of the consolidation of democracy (MacLennan 2000: 167).

The 23F demonstrated that the European Community did not have any power to prevent the peril of military intervention. The EC's democratic conditionality at that time lacked any specific rules regarding the civil-military relations. The EU set specific conditions regarding the civilian control of the military for the CEE enlargement countries and Turkey but not developed such conditions for the Southern enlargement countries. As a result, the EC accession process did not have any direct link with the military reforms made by the UCD and PSOE governments.

Spain's entry to NATO (May 1982) provided several contributions to the civilian control of the military. Civilian bureaucracy and military officers received training about civilian control at NATO headquarters in Belgium (Bruneau 2000: 11). Juan Carlos favored the NATO membership by expecting that it would not only help Spain's bid for the EC membership but also shift the army's focus from domestic politics to external

\footnotetext{
${ }^{61}$ Online communication with Charles Powell on October 16, 2011. The author made face-to-face interview with Professor Powell in Madrid on June 29, 2009.
} 
security issues (Preston 2004: 443). During the author's field study in Spain, several interviewees confirmed that the NATO membership helped moving away the military's focus from domestic politics to security affairs. ${ }^{62}$ Moreover, technical modernization of the Spanish army in the aftermath of the NATO accession facilitated the PSOE government's drive for military reforms favoring the civilian control of the military (Banon-Martinez 1991: 246-48, Serra 2010: 139). Despite these contributions, NATO's democratic effects were limited to a certain extent. For the Spanish Socialists and Communists, NATO was not affiliated with democracy due to Franco's military ties with the US. ${ }^{63}$ For the Spanish right, accession to NATO was mostly considered as a strategic issue, and the link between NATO membership and depoliticization of the military remained in the shadow of security considerations. ${ }^{64}$ As the former minister of defense Narcis Serra stated that Spain's NATO membership would have been compatible even if "the Spanish transition had headed towards a semi-democracy" (Serra 2010: 139).

\section{Legitimacy, anti-system parties, stateness}

The last component of democratic consolidation relates to the degree to which democracy as a political regime receives support from people and major groups within

\footnotetext{
${ }^{62}$ Interviews with J. M. Fernandez, A. Gutierrez, and E. Curiel.

${ }^{63}$ Before the 1982 elections, PSOE took a clear position against Spain's membership in NATO (1981). During the Socialist rule (1982-86), Prime Minister Felipe Gonzalez made a u-turn in PSOE's position, and campaigned for a Yes vote in the 1986 referendum for NATO membership. An important dynamic behind PSOE's policy shift was Gonzalez's pragmatical concern about the link between the EC and NATO membership. He considered that Spain's withdrawal from NATO could have negative repercussions on her bid for the EC membership (Arango 1995: 288-91, Marks 1997: 43-75). In the referendum (March 12, 1986), 53 percent of Spanish voters supported maintenance of the NATO membership while the 40 percent voted No for the question that "Do you think it advisable for Spain to remain in the Atlantic Alliance under the terms set down by the government?".

${ }^{64}$ Interview with C. Powell
} 
society. In consolidated democracies, people prefer democracy as the best type of regime. In addition, no politically significant political party/group works for an alternative political regime or seeks for secession. In this dimension of consolidation, the Spanish democracy did have a high level of progress in just a few years after the death of Franco; nevertheless, the Basque question continued to pose a serious challenge until the mid1980s.

The transition from the centralized authoritarian political regime to the decentralized parliamentary monarchy was swift. The consensus and compromises between the Spanish right and left found an overwhelming support from the Spanish people as demonstrated in the June 1977 founding elections and in the December 1978 constitutional referendum. The Spanish political parties and people also revealed their democratic credentials in the aftermath of the February 1981 coup attempt. Peaceful alternation of political power in the October 1982 elections for the first time in the postFranco period, was another key moment. Therefore, Spain's domestic dynamics did have a primary role in the fourth component of democratic consolidation. The cause of European integration and the EC accession process also played important symbolic and practical roles. Spain's bid for the EC membership received strong support from the Spanish people, political parties, the King, and the business. The membership symbolized democratic, modern and European Spain as a clear distinction from the authoritarian and isolated Francoist Spain. In addition, the prospective and actual EC membership enhanced the legitimacy of post-Franco Spain in the eyes of the Basque and Catalan nationalists. 
The following section will examine the major issues and dynamics in the realm of the fourth component of democratic consolidation. Then, it will assess the role of European integration.

\section{Public Legitimacy}

Although many studies have underlined the key role of elites in the Spanish transition, mass behavior should not be understated. Spaniards provided an overwhelming support to their democratic system in every key moment: the December 1976 Law for Political Reform referendum, the June 1977 elections, the 1978 constitutional referendum, the March 1979 elections, the failed coup of 23F, and the October 1982 elections. The elections and referendums recorded high levels of turnout, except large abstention rates in the Basque region for the constitutional referendum. The table 3.3 provides turnout rates in the referendums and elections from 1976 to 1986.

Table 3.3: Turnout Rates in Spanish Referendums and Elections (1976-1986)

\begin{tabular}{|l|l|}
\hline Referendums \& Elections & Turnout \\
\hline $\begin{array}{l}\text { Referendum for the Law of Political Reform } \\
\text { (December 1976) }\end{array}$ & $78 \%$ (\% 94 support) \\
\hline The June 1977 Parliamentary Elections & $79 \%$ \\
\hline The Constitutional Referendum (December 1978) & $\begin{array}{l}67 \% \text { (\% 88 yes, \% 8 no); } \\
\text { the Basque turnout 46\% }\end{array}$ \\
\hline The March 1979 Elections & $68 \%$ \\
\hline The October 1982 Elections & $80 \%$ \\
\hline The October 1986 Elections & $70 \%$ \\
\hline
\end{tabular}

Source: The website of the Spanish Ministry of Interior (http://www.infoelectoral.mir.es/min/)

In regard to mass attitudes toward democracy, democratic system has enjoyed high levels of legitimacy since the early-1980s. In several survey studies, Spaniards were 
asked whether democracy is the best political system for their country and whether an authoritarian regime, under some circumstances, is preferable to a democratic regime (Montero 1993: 146, Linz et al 1995: 97, Morlino and Montero 1995: 236). The surveys confirmed that an overwhelming majority of people preferred democracy over any other political regime. Moreover, seventy-six percent of the Spanish people viewed the democratic transition as a source of pride (only nine percent did not) according to a survey made in 1985 (Linz et al 1995: 96). Table 3.4 reports some of these results.

Table 3.4: The Legitimacy of Democracy in Spain, 1980-1990 (in percentage)

\begin{tabular}{|l|l|l|l|l|l|l|l|}
\hline Survey Questions & $\mathbf{1 9 8 0}$ & $\mathbf{1 9 8 4}$ & $\mathbf{1 9 8 5}$ & $\mathbf{1 9 8 7}$ & $\mathbf{1 9 8 8}$ & $\mathbf{1 9 8 9}$ & $\mathbf{1 9 9 0}$ \\
\hline $\begin{array}{l}\text { Democracy is preferable to any other } \\
\text { form of government }\end{array}$ & $49 \%$ & $69 \%$ & $70 \%$ & $71 \%$ & $72 \%$ & $68 \%$ & $90 \%$ \\
\hline $\begin{array}{l}\text { Under some circumstances, an } \\
\text { authoritarian regime, a dictatorship, } \\
\text { is preferable to a democratic system }\end{array}$ & $10 \%$ & $11 \%$ & $10 \%$ & $12 \%$ & $10 \%$ & $10 \%$ & $7 \%$ \\
\hline $\begin{array}{l}\text { For people, like me, one regime is } \\
\text { the same as another }\end{array}$ & $8 \%$ & $11 \%$ & $9 \%$ & $11 \%$ & $10 \%$ & $10 \%$ & $8 \%$ \\
\hline Don't Know, No Answer & $33 \%$ & $9 \%$ & $11 \%$ & $6 \%$ & $8 \%$ & $12 \%$ & $5 \%$ \\
\hline
\end{tabular}

Source: CIS Survey, Madrid; cited in Montero 1993: 146

The process of European integration contributed to the legitimacy of the democratic regime in several ways. First, the European Community as a club of wealthy and democratic countries has received high levels of support from Spaniards. Particularly important, European integration was directly linked to modernization and economic development. All interviewees whom the author contacted in Madrid in summer 2009, without any exception, noted this link. Second, the prospective and actual EC 
membership increased the legitimacy of Western style democracy, and served to delegitimize alternatives to democracy (Day et al 2000: 24) ${ }^{65}$. Overall, the Europeanization and democratization processes converged to a large extent during the post-Franco era. European integration reinforced the legitimacy of the re-born democracy for the Spanish people.

\section{Elite Consensus and Anti-System Parties}

While mass attitudes were largely helpful for the consolidation of Spanish democracy, developments at the elite level were also quite favorable. In particular, the acceptance of the monarchy and the reformist mode of transition by the Socialist (PSOE) and Communist (PCE) parties not only resulted in a fast-track transition process but also made a substantial contribution to the consolidation of democracy. The extreme-right and the extreme-left forces made efforts to halt the transition process through the use of violence but they failed to attract a considerable mass support. The centrist/moderate character of the Spanish electorate, demonstrated in the 1977 and 1979 elections, also influenced to a great extent changes within the PSOE and PCE in favor of conciliatory policies.

The Socialists and the Communists, the losing sides in the Civil War, were clandestine forces during the Franco era. By the time of Franco's death, they demanded a radical break from the past (ruptura), and stood against the monarchy. Yet, once Suarez steered the fast-track transition process with the help of Juan Carlos's firm support, the leftists opted for the gradual change and recognized the monarchy. The Communists

${ }^{65}$ J.C.Pereira, "From democratic transition to Spain's accession to the European Communities (19751985)", European Navigator (ENA) Paper. Available online at: http://www.ena.lu/democratic_transition_spain_accession_european_communities-2-38132 
acknowledged the monarchy a few days after the PCE's legalization in April 1977; the PSOE did the same following the 1978 constitutional referendum. (Powell 1996: 125) In addition, both parties gave their support to Suarez's austerity program outlined in the Moncloa Pact (September 1977).

The Spanish left realized moderation in party ideology in the mid-to-late 1970s. The PCE broke up the Soviet connections, and followed "Eurocommunist" line (Bell 1983: 63-77). From 1976 to 1979, the PSOE undertook a significant transformation. The social democratic wing in the party, led by Felipe Gonzalez, pushed the PSOE towards the center. For Gonzalez, PSOE's moderation was necessary for the party to be able to run government in the critical period of political transformation. Otherwise, the Spanish political scene could have experienced a collapse of the democratic transition due to an intervention by the military. ${ }^{66}$ For the Socialists, the PSOE's right-wing drift was necessary to strengthen Spain's fragile democracy and to make it consolidated. ${ }^{67}$ The party made democratic consolidation, economic modernization, European integration and decentralization the priorities of its rule (1982-96). Although it undertook fundamental reforms in the area of civilian control of military, the PSOE leadership was very careful not to antagonize the army. As many observers of Spanish politics have agreed, the PSOE made substantial contribution to the consolidation of democracy with its prudent but

\footnotetext{
${ }^{66}$ A top adviser to Felipe Gonzalez stated in 1986: "The PSOE has governed for almost four years with coherence and prudence, always preferring to be accused of excessive moderation rather than risking mistakes. Thanks to this, social tension that might favor a coup does not exist" (Share 1989: 142).

${ }^{67}$ In an interview, made in January 1982, Javier Solana (PSOE Executive Committee member) stated: "Democracy and its consolidation come first, before our political programmes. These might take twenty or thirty years to put into practice. Why this order of priorities? Because the Spanish right has shown that it can live very well under both authoritarian and democratic regimes while the left can only survive within a democratic framework. We have a lot of pain suffering, and many years behind bars, to prove that" (Share 1985: 92).
} 
reformist policies (Nash 1983: 29-62, Gunther 1986: 10-25, Payne 1986: 185-95, Share 1989: 35-95, Tusell 2007: 321-49).

With regard to the consolidation of democracy, the Popular Alliance's (AP) role should also be noted. The Party's leader, Manuel Fraga, served several years as Minister of Tourism (1962-69) during the Franco rule. Later, he became vice prime minister and minister of interior in Arias Navarro's government. Although he was one the reformist members of the Francoist elite, Fraga followed a more nationalist and conservative line compared to Suarez/the UCD. Nevertheless, his conservatism did not amount to opposing the transition in general. He took part in the constitution-making process, and he participated in the marches of democracy after the failed 23F coup (Young 1983: 142-3, Bonime-Blanc 1987: 35-46, Morlino 1995: 364). After the dissolution of UCD (1979-82), Fraga moved to the center and attempted to gain support from the UCD voters in the October 1982 elections. In both the 1982 and 1986 elections, Fraga's party gained 26 percent falling short of the PSOE. Later on, the party was re-organized under the name Partido Popular and became a center-right party in Spanish politics. Therefore, the transformation of the Alliance Popular from a neo-Francoist party into a pro-democratic center-right party also made an important contribution to the consolidation.

The Spanish left and right received various types of support from European political parties during the consolidation process. While the Socialist International and the German SPD provided organizational, financial, and moral support to the PSOE, the Eurocommunist Italian Communist Party had close relations with the PCE. European conservative parties and the Christian Democratic International established links with the UCD and AP. These relations reinforced democratic commitments of the Spanish 
political parties. Moreover, the cause of European integration and the EC accession also had democratizing effects on the part of Spanish parties. Having symbolized higher standards of democracy and human rights, accession to the EC found a cross party consensus in post-Franco Spain. For the left, European integration was intrinsically related to democratic consolidation (Tovias 1995: 103, Mujal-Leon 1986: 211). In addition, the Spanish left considered the integration as a key dynamic to accelerate eradication of the Francoist legacy. For instance, two members of the Spanish left, whom the author interviewed in Madrid, confirmed that European integration accelerated overcoming the Francoist legacy. ${ }^{68}$ For the right, economic modernization was a key component of EC membership. On the whole, European political party linkages and the EC accession process helped to reinforce the legitimacy of democracy among the Spanish political parties.

\section{Stateness}

Spain's consolidation process has benefited from the democratic orientation of the Spanish people, the pro-democratic evolution of the Francoist elite (the UCD and AP) and the legalization of PCE in return for accepting the monarchy. The transformation of PSOE and its conciliatory but reformist character under the leadership of Felipe Gonzalez was also a great asset. Yet, Spain's nascent democracy had to deal with a serious challenge: decentralization in general, and the Basque problem in particular. On the one hand, the question posed an additional burden for Spain's democratization since a democratic regime in multi-national states requires inclusive policies satisfying different

\footnotetext{
${ }^{68}$ Interviews with E.Curiel and J.M.Fernandez.
} 
ethnic groups (Linz and Stepan 1996: 33-7). On the other hand, the military hardliners did have more justification for the coup plots when a key pillar of the Francoist order (strict centralism) was facing collapse. Moreover, the escalation of ETA terrorism against the security forces (military and police) and the civilians beginning in 1977, posed a severe threat for both the transition and the consolidation processes (Chislett 1975-78, McClellan 1978: 48-58, Carr and Fusi 1981, Share 1989: 51). ${ }^{69}$

During the Second Republic (1931-36), the Basque and Catalan regions earned the status of autonomy. After the Civil War, the Franco regime abolished this status and responded to the autonomy demands with repression. On the one side, the repression enabled international recognition of the Basque problem. On the other side, it contributed to the emergence of radical nationalist forces including the ETA. Beginning in the late 1960s, the ETA executed several incidents of violence including the assassination of Prime Minister Carrero Blanco in December 1973. In the transition process, ETA's fundamental goal was to halt the transition by launching a mass rebellion following a military coup. It planned to provocate the army through escalation of violence. In contrast, the Basque Nationalist Party (PNV), an important force in the Basque nationalism was open to the idea of decentralization within the democratic framework. The PNV's position, as a moderate Christian democratic party, was distinct to a great extent from the secular-revolutionary ETA (Gunther 1986: 38-40, Ozcer 2006: 30-128, Lecours 2007: 62-97).

\footnotetext{
${ }^{69}$ From 1976 to 1986 , more than six hundred people became victims of terrorism in Spain, and the ETA was responsible for about $75 \%$ of these casualties. Particularly notable, the ETA targeted the police and the military; $90 \%$ of the killings by security forces (more than three hundred people) were made by the ETA (El Pais, May 4, 1986 cited in Aguero 1995: 143). In 1979 and 1980, the ETA killed nine generals (Vilanova 1983: 162).
} 
The Basque Nationalist Party took part in the constitution making process. It demonstrated the PNV's willingness to find a solution to the Basque problem within the democratic system (Bonime-Blanc 1987: 88-9). But, the PNV did not find the degree of self-government in the 1978 constitution sufficient; hence, it called for abstention in the referendum. The other two Basque nationalist parties, Herri Batasuna (HB) and Euskadiko Ezkerra (EE), supported the "no" vote. Consequently, a wide majority of the Basque people abstained (55\%); support for the constitution in the Basque provinces was lower (ranging from $63 \%$ to $71 \%$ ) than the national average (88\%). The large abstentions in the Basque region posed a serious problem of legitimacy for the Spanish democracy. The approval of the Basque statute of autonomy (90\% support, $60 \%$ turnout) in the October 1979 referendum helped to resolve the legitimacy question to a considerable extent. Both the PNV and the EE supported the statute while the HB (the closest party to ETA within the region's nationalist parties) preferred abstention (Lecours 2007: 89-96). One year later, the first elections were held for the Basque government. The HB, an antisystem party for many observers of Spanish politics ${ }^{70}$, received between 14 and 18 percent of the vote in the four Basque elections from 1980 to 1990, while the PNV remained the leading party. The following table provides the results of these elections.

\footnotetext{
${ }^{70}$ For example; Morlino 1995b: 344
} 
Table 3.5: Basque election results, 1980 to 1990

\begin{tabular}{|l|l|l|l|l|}
\hline Parties & $\mathbf{1 9 8 0}$ & $\mathbf{1 9 8 4}$ & $\mathbf{1 9 8 6}$ & $\mathbf{1 9 9 0}$ \\
\hline PNV & $38 \%(25)$ & $42 \%(32)$ & $23.7 \%(17)$ & $28.4 \%(22)$ \\
\hline PSE-PSOE & $14 \%(9)$ & $23 \%(19)$ & $22 \%(19)$ & $19.9 \%(16)$ \\
\hline HB/EH/BAT & $16.5 \%(11)$ & $14.6 \%(11)$ & $17.4 \%(13)$ & $18.3 \%(13)$ \\
\hline EE & $9.8 \%(6)$ & $7.9 \%(6)$ & $10.8 \%(9)$ & $7.7 \%(6)$ \\
\hline PCE/IU & $4 \%(1)$ & $1.4 \%(0)$ & $0.5 \%(0)$ & $1.4 \%(0)$ \\
\hline AP/PP & $4.8 \%(2)$ & $9.3 \%(7)$ & $4.8 \%(2)$ & $8.2 \%(6)$ \\
\hline UCD/CDS & $8.5 \%(6)$ & - & $3.5 \%(2)$ & $0.6 \%(0)$ \\
\hline EA & - & - & $15.8 \%(13)$ & $11.3 \%(9)$ \\
\hline Others & $4 \%(0)$ & $1.5 \%(0)$ & $1.1 \%(0)$ & $3.7 \%(3)$ \\
\hline
\end{tabular}

Note: Entries are \% of votes, \# of seats in parentheses.

Source: Lecours 2007: 96

As suggested earlier, the ETA aimed at halting the transition process and establishing an independent Basque state. For this purpose, it escalated the acts of violence beginning in 1977 , and primarily targeted the military officers and the police forces. Nonetheless, the ETA terrorism fell short of posing a substantial legitimacy problem for Spanish democracy when the formula of autonomous community worked well in the Basque region. The ETA and its political supporters (the HB i.e.) remained mostly on the margins of Basque politics. In this regard, two key developments in the 1980s were quite notable. First, following the 1984 Basque elections, the PNV formed a coalition government with the PSOE. The PSOE-PNV cooperation contributed to the isolation of ETA from the Basque political scene. In addition, assurances in the coalition agreement enhanced PNV's loyalty to Spain's democratic regime (Gunther 1992: 41-2, Ozcer 2006: 228-9). Second, the 1988 Pact of Ajuria-Enea, signed by all political parties except the Herri Batasuna, was a landmark development to strengthen the system of autonomous community and to deal with the ETA problem by democratic means. The 
pact involved a condemnation of political violence and an appeal to ETA to give up the armed struggle. The overwhelming support for the Pact from all political parties in the region (except the HB) helped to build an unanimous consensus against violence (Ozcer 2006: 249-61, Lecours 2007: 96, Guittet 2008: 267-75). The consensus enhanced the legitimacy of the 1978 autonomous communities formula, and contributed to the consolidation of Spanish democracy in the Basque region.

In contrast to the Basque region, the Catalans never posed a threat for Spain's democratic transition and consolidation processes. They took part in the 1978 constitution making process, and approved the Catalan Statute of Autonomous Community in the 1979 referendum (Bonime-Blanc 1987: 35-46, Guibernau 2004: 70-84). The system of autonomous community worked well in the region, and the Catalans became enthusiastic supporters of European integration. Particularly notable, the Catalans were highly proud of their multiple identities (Catalan, Spanish, and European), according to surveys made in the late 1980s (Linz and Stepan 1996: 102).

With regard to the last component of democratic consolidation (legitimacy, antisystem parties, stateness), one can conclude that the Spanish democracy became consolidated by the mid-to-late 1980s. The Spanish people provided an overwhelming support to the transition from the Francoist regime to the democratic one. The marches for democracy by millions of Spaniards after the failed 23F coup attempt were a clear demonstration for this support. Survey studies made in the 1980 s also confirmed the existence of a strong legitimacy for the democratic regime. At the national level, the reborn democracy did not face an anti-system party. The reformist but prudent orientation of the Socialist and the Communist Parties, along with the pro-democratic evolution of 
the right-wing Alliance Popular, facilitated the democratic transition and contributed to its consolidation. The Basque question posed a serious challenge. It had the capacity to reverse the transition process if the Spanish political elite, did not succeed keeping the army in the barracks. The Basque problem also complicated the process of democratic consolidation. However, the early creation of a system of autonomous communities and its successful implementation resulted in the political isolation of ETA in the mid-to-late 1980s. The PSOE's cooperation with the PNV and the building of a political consensus against terrorism strengthened the level of legitimacy for the democratic regime in the Basque region.

In the fourth component of democratic consolidation, Spain's domestic dynamics did have a primary role. Yet, the prospective and actual EC membership also made significant contributions. The high degree of public support for the democratic regime along with democratic commitments of the Spanish left and right resulted in the fast track transition process, and they substantially accelerated the consolidation. The particular nature of Spain's political history (the Civil War trauma and the longevity of Francoist regime, i.e.) was to a great extent responsible for the high level elite consensus on the democratic character of post-Franco Spain. ${ }^{71}$ As a result, domestic dynamics were of central importance but one cannot understate the significant role of European integration for reinforcement of the legitimacy of democratic regime. An overwhelming majority of the Spanish people and elite considered European integration as an essential part of the democratization process. Symbolically, the post-Franco process of political transformation could not be complete without accession to the European Community.

\footnotetext{
${ }^{71}$ Interview with C. Powell.
} 
Europeanization and democratization converged to a large extent, and they reinforced each other.

European integration also made an important contribution to Spain's regional question. Certainly, domestic dynamics were most decisive in the process of transition from the centralized state structure to the decentralized one. The system of autonomous communities, which was launched in the 1978 constitution and the subsequent process of emerging consensus against violence were the key developments. Spain's decentralization process was not set by the $\mathrm{EC}$ as a condition for the Community membership. Nonetheless, European integration played indirect and facilitating roles in this area. The Basque and Catalan people, who were strongly in favor of the integration felt more comfortable with overlapping identities; the Basque/Catalan, Spanish, and European. Moreover, European level relations decreased demands for independence on the part of regional nationalists (Llamazares and Marks 2006: 256-8). On the whole, Spain's decentralization process and European integration went hand in hand, and it was very helpful for the consolidation of Spanish democracy. ${ }^{72}$ Furthermore, the Spanish military, which was obsessed with the unitary state structure, noticed that special treatment of regions in EC member states does not pose a threat for territorial integrity of the state. European integration assuaged to an important extent the anxiety of the army about decentralization in the post-Franco Spanish state (Garcia 1995: 129-39).

\footnotetext{
72 The Basque and Catalan political elite have been very proud of being part of the system of European regions. For example, Jordi Pujol who was the president of the Catalan autonomous community (19802003) served as a president of the Assembly of European regions between 1992 and 1996 (Genieys 1998: 180).
} 
Table 3.6 reveals the domestic and European dynamics of democratic consolidation in Spain by different components of the consolidation. In what follows, an overall analysis of the democratizing impact of European integration will take place.

Table 3.6: European versus Domestic Dynamics of the Consolidation

\begin{tabular}{|c|c|c|c|}
\hline $\begin{array}{l}\text { Components } \\
\text { of Democratic } \\
\text { Consolidation }\end{array}$ & $\begin{array}{l}\text { Major Events- } \\
\text { Key Developments }\end{array}$ & Domestic Dynamics & European Dynamics \\
\hline $\begin{array}{r}\text { 1.Free, fair, } \\
\text { and } \\
\text { competitive } \\
\text { elections }\end{array}$ & $\begin{array}{r}\text {-The Law of Political } \\
\text { Reform (12/'76) } \\
\text {-PCE Legalization (4/'77) } \\
\text {-First Elections (6/'77) }\end{array}$ & $\begin{array}{r}\text {-King's support for the swift } \\
\text { transition } \\
\text {-Suarez's leadership skills } \\
\text {-Suarez and PSOE-PCE } \\
\text { cooperation }\end{array}$ & $\begin{array}{r}\text {-EC's signal for } \\
\text { democratic } \\
\text { conditionality (DC) } \\
\text {-European Parliament's } \\
\text { resolutions for the } \\
\text { transition reforms } \\
\text {-European political } \\
\text { parties links } \\
\text {-EC's DC: anchor role }\end{array}$ \\
\hline $\begin{array}{r}2 . \text { The } \\
\text { protection of } \\
\text { basic rights } \\
\text { and liberties }\end{array}$ & $\begin{array}{r}\text {-Amnesty (8/’77) } \\
\text {-Moncloa Pact (9/’77) } \\
\text {-'78 Constitution (Dec) }\end{array}$ & $\begin{array}{r}\text {-Elite consensus- } \\
\text { compromises (influenced by } \\
\text { the memory of the Civil War } \\
\text { and the longevity of the } \\
\text { Franco Era) }\end{array}$ & $\begin{array}{r}\text {-E. Council Copenhagen } \\
\text { Declaration / April } 78 \\
\text {-Council of Europe } \\
\text { conditionality } \\
\text {-Europe as a model for } \\
\text { the new constitution } \\
\text {-EC's DC: anchor role }\end{array}$ \\
\hline $\begin{array}{r}\text { 3.High } \\
\text { prospects of } \\
\text { regime } \\
\text { survival and } \\
\text { the civilian } \\
\text { control of } \\
\text { army }\end{array}$ & $\begin{array}{r}\text { - } 6 \text { Coup Plots ('77-'85) } \\
\text { - February 23, } 1981 \text { coup } \\
\text { (23F) } \\
\text { - Military Reforms }\end{array}$ & $\begin{array}{r}\text {-King's commitment to the } \\
\text { democracy } \\
\text {-The civilian unity against } \\
\text { coups } \\
\text {-Public support for } \\
\text { democracy \& 23F marches } \\
\text {-UCD-Mellado reforms }\end{array}$ & $\begin{array}{r}\text {-EC; no power to prevent } \\
\text { the breakdown of } \\
\text { democracy }(23 \mathrm{~F}, \text { i.e. }) \\
\text {-EC's immediate } \\
\text { response in favor of } \\
\text { democracy after the } 23 \mathrm{~F}\end{array}$ \\
\hline
\end{tabular}




\begin{tabular}{|c|c|c|c|}
\hline & & $\begin{array}{c}\text {-PSOE reforms } \\
-23 \mathrm{~F} \text { Trials }\end{array}$ & $\begin{array}{r}\text {-EC's DC; not have any } \\
\text { specific rules for the } \\
\text { civilian-military } \\
\text { relations } \\
\text {-European integration; } \\
\text { reinforcing role } \\
\text {-NATO membership; } \\
\text { help for focus change in } \\
\text { the military }\end{array}$ \\
\hline $\begin{array}{r}4.1 \\
\text { Legitimacy }\end{array}$ & $\begin{array}{r}\text {-Elections ('77, '79, '82) } \\
\text {-Referendums ('76, '78) } \\
-23 \mathrm{~F}\end{array}$ & $\begin{array}{l}\text {-Public opinion surveys show } \\
\text { strong support for democracy }\end{array}$ & $\begin{array}{r}\text {-European integration; } \\
\text { reinforcing and symbolic } \\
\text { role for the re-born } \\
\text { democracy } \\
\text {-High mass and elite } \\
\text { support for the } \\
\text { integration }\end{array}$ \\
\hline $\begin{array}{l}\text { 4.2 Anti- } \\
\text { System } \\
\text { Parties }\end{array}$ & $\begin{array}{r}\text { - PSOE-PCE acceptance } \\
\text { of the monarchy } \\
\text {-HB in the Basque Region }\end{array}$ & $\begin{array}{r}\text {-AP, pro-democratic } \\
\text { evolution } \\
\text {-PSOE ideological } \\
\text { moderation }\end{array}$ & $\begin{array}{r}\text {-SPD-SI's strong support } \\
\text { for the PSOE } \\
\text {-PCE and AP had links } \\
\text { with European political } \\
\text { parties } \\
\text {-European integration } \\
\text { had cross party } \\
\text { consensus }\end{array}$ \\
\hline 4.3 Stateness & $\begin{array}{r}\text {-Referendum for '78 } \\
\text { Constitution } \\
\\
\text {-'78-'83 Autonomy } \\
\text { Statuses (17 regions) } \\
\text {-'84 PSOE-PNV } \\
\text { Coalition } \\
\text {-'88 AE Pact }\end{array}$ & $\begin{array}{r}\text {-PNV dominance in the } \\
\text { Basque politics } \\
\text {-PSOE-PNV cooperation } \\
\text {-Consensus for condemnation } \\
\text { of violence (AE Pact) }\end{array}$ & $\begin{array}{r}\text {-Basque/Catalans had a } \\
\text { high support for EC } \\
\text { accession } \\
\text {-European integration } \\
\text { went hand in hand with } \\
\text { regionalism } \\
\text {-European level relations } \\
\text { lessened demands for } \\
\text { independence } \\
\text {-Overlapping identities; } \\
\text { regional, Spanish, } \\
\text { European }\end{array}$ \\
\hline
\end{tabular}


Spain's domestic dynamics played a central role in both the transition and the consolidation processes. Yet, one also should acknowledge that the post-Franco political transformation was significantly affected by European factors, such as the European Community institutions, the EC accession process, and European political parties. The prospective and actual EC membership has anchored the Spanish democracy through the EC's democratic conditionality. European integration was an intrinsic part of the postFranco transformation in three realms: democratization, modernization/economic development, and foreign policy change. The integration not only reinforced the legitimacy of democracy but also facilitated the decentralization process, launched through the formula of autonomous communities in the 1978 constitution. In sum, European dynamics played contributing, facilitating, and accelerating roles in the process of democratic consolidation. Without such a favorable European context, the Spanish democracy might have been consolidated in a longer period. Having acknowledged the significance of EC's democratizing role, the Spanish political elite including Juan Carlos and Felipe Gonzalez clearly linked European integration with democratic consolidation (Tavias 1984: 163, Lieberman 1985: 43, Share 1989: 50-51, Huntington 1996: 191-3).

The EC accession process and other European dynamics helped the consolidation process of Spanish democracy, but one should also identify the limits of the European contribution. First of all, unless the Spanish masses and elites (political and business) had fully supported the cause of European integration, European actors could not have much democratizing impact in the post-Franco Spain. Neither the EC institutions nor European political parties did have any enforcing power over the Spanish state and political parties. Therefore, Europe's democratizing help was highly contingent upon the pro-European 
Spanish scene. Second, as demonstrated in the case of the February 1981 coup, the European Community did not have any leverage to prevent a severe risk of democratic breakdown. After the event, the EC responded immediately in favor of the democratic regime; yet, the domestic dynamics, including the King's firm commitment to democracy and the civilian unity against the coup, were more decisive. Third, the EC's democratic conditionality in the cases of Southern Enlargement including Spain was not very rigorous. ${ }^{73}$ As a result, the EC accession process did not have any direct role in the key military reforms handled under the UCD and PSOE governments in Spain.

The author's interviews in Spain largely supported the view that European integration made significant contributions to the Spanish democracy. ${ }^{74}$ Except a current member of the Parliament from the center-right Partido Popular ${ }^{75}$, all interviewees confirmed that the EC accession process helped the Spanish democracy in several areas: the civilian control of military, political stability, and the removal of Francoist legacy. In addition, many of them underlined the importance of support given by European political parties to their counterparts in Spain. ${ }^{76}$ Some interviewees noted the significant role of European integration for the shaping of Spanish identity at the international level. ${ }^{77}$ Moreover, without exception, all agreed on the crucial role of European integration for

\footnotetext{
${ }^{73}$ While the European Union developed more specific democratic conditionality rules in the area of human rights and the civilian-military relations for the Central and Eastern European candidates, the democratic conditionality for the Southern European countries lacked such a specifity.

${ }^{74}$ See Appendix 2 for the list of interviewees in Spain. For the interview questions, see Appendix 1. In addition to the field study of June-July 2009 in Madrid, a few numbers of Spanish academicians have been contacted, mostly through electronic mail, before and after the field research.

${ }^{75}$ Interview with Antonio Gutierrez.

${ }^{76}$ Interviews with Antonio Gutierrez and Jose Manuel Fernandez.

${ }^{77}$ Interviews with Ignocio Molina, Enrique Curiel, and Antonio G. Terol.
} 
the modernization of Spanish economy. When they were asked for the major problems of Spanish democracy during the EC accession process, many politicians and scholars indicated the military, the Franco legacy, the Basque problem and terrorism. ${ }^{78}$ For the timing of democratic consolidation, the mid-1980s received the broadest support. ${ }^{79}$

Distinct from the Greek and Portuguese cases, cross party consensus on European integration was confirmed by all interview participants. Affiliating with either the right or left of the political spectrum, the interviewees noted that all Spanish political parties except the extreme right and left supported the EC membership. Some participants suggested that the Spanish political parties did have some differences in the assessment of European integration (values, priorities i.e.) yet all desired for the EC membership. ${ }^{80}$ When they were asked for their personal opinion about Spain's accession to the EC, all interviewees expressed pro-EC views. Many participants suggested that European integration symbolized democracy, modernization, political stability, and economic development. ${ }^{81}$ Some participants, who are affiliated with the Spanish right emphasized more the economic benefits than the democratizing impact of EC accession. ${ }^{82}$ In addition, some interviewees suggested that Spain's NATO membership contributed more than the

\footnotetext{
${ }^{78}$ Interviews with Jose Manuel Fernandez, Jorge Verstrynge, William Chislett, Charles Powell, and an anonymous official from the Partido Popular.

${ }^{79}$ For instance; Enrique Curiel, Antonio Gutierrez, Charles Powell, and Ignocio Molina. J. M. Fernandez pointed to the 1996 elections as a point of consolidation by following Huntington's two turnover test for the consolidation.

${ }^{80}$ For instance; Antonio Gonzalez and Jose Manuel Fernandez.

${ }^{81}$ For example; Jorge Verstrynge, Enrique Curiel and Jose M. Fernandez.

${ }^{82}$ For instance; Antonio G. Terol and Antonio Gutierrez.
} 
EC membership to the civilian control of the military ${ }^{83}$ Moreover, many participants underlined the significant role of the EC accession to overcome the isolationist foreign policy orientation of the Franco period and to endorse the European identity of Spaniards. ${ }^{84}$

Overall, the two-month field study in Madrid has been very helpful to gather observations from Spanish politicians and scholars. In general, the interviews have widely supported the idea that European integration made significant contributions to the Spanish democracy.

\section{Conclusion}

After the end of four decade long authoritarian era, the post-Franco Spain experienced a non-revolutionary but a speedy transition to democracy. The international context was certainly favorable while domestic factors were of primary importance in the course of such a swift democratic transition. Conditioned by structural changes in the late Franco period, consensus and compromises between the reformist right and the conciliatory left substantially shaped the transition. Spain's domestic dynamics continued to be the key factor, while European integration as an interdependent and parallel process became an intrinsic part of the Spanish consolidation. Symbolically, the post-Franco political transformation could not be complete without accession into the $\mathrm{EC}$ for the majority of Spanish masses and elites. In practice, the EC accession process and

\footnotetext{
${ }^{83}$ Ignocio Molina held this view. J M. Fernandez and Josefina Cuesta also noted the positive role of NATO membership for the civil-military relations. Charles Powell suggested that NATO membership was helpful for the military reforms made during PSOE rule but the reforms would have been done anyway even if Spain had not joined NATO.

${ }^{84}$ Interviews with Enrique Curiel, Ignocio Molina, and Antonio-Carlos Pereira.
} 
European political parties enhanced different components of the consolidation. The Spanish people and political parties were overwhelmingly pro-European as they considered EC membership as essential for the democratization and the economic modernization of the country. In addition, European integration was deemed, particularly by the left, a key process to eradicate the legacy of the Franco period.

Europeanization and democratization went hand in hand, and they reinforced each other to a great extent. The convergence of two processes was certainly very helpful for the fledgling Spanish democracy. Faced with serious threats including coup plots, political violence, and Basque separatism, the reborn democracy benefited from the EC accession process and the help coming from European political parties. The EC's democratic conditionality anchored the Spanish democracy. European integration reinforced the legitimacy of democracy, and facilitated the decentralization process. Nonetheless, neither the EC's democratic conditionality nor European political parties had any leverage to prevent a serious risk of democratic breakdown as seen in the February 1981 coup attempt. Besides, the EC's democratic conditionality at that time lacked a significant level of rigor in the realm of human rights and civilian-military relations. Despite these limitations, one can conclude that European integration accelerated to a great extent the consolidation of Spanish democracy. 


\section{CHAPTER IV}

\section{EUROPEAN INTEGRATION AND DEMOCRATIC CONSOLIDATION: THE CASE OF POST-COMMUNIST POLAND}

One and a half decade after the collapse of the Communist regime, Poland joined the European Union (EU) on May 1, 2004. In an important way, the EU accession confirmed that Poland's political and economic transformation towards liberal democracy and a market economy was a success story. With the cause of European integration finding an overwhelming support from both the political elite and the people, the EU membership process developed into a highly favorable external force behind the political and economic reform process of post-Communist Poland. In the wake of the Polish transition to democracy following the 1989 Round Table talks, the EU followed a very cautious line about remarkable developments in the country. Only after a few years later when the Central and Eastern European (CEE) countries forcefully demanded full membership, did the EU launch the accession process at the historic Copenhagen meeting in June 1993. While the EU's impact over Poland's democratic transition (1989-1991) was not significant; the post-Copenhagen period of accession process involved the EU's increasing leverage over the domestic political changes in the country.

With carrying out the first fully competitive parliamentary elections in October 1991, Poland's democratic transition was complete to a great extent. Yet, major challenges remained to overcome: the lack of a democratic constitution, frequent government changes, fragmented party politics, institutional uncertainties over the legislative-executive relations, particularly the presidential powers, occasional political crises in the realm of civilian control of the army, and public disenchantment over the 
post-1989 changes owing to a painful market reform process. The April 1997

constitution, a positive impact of the NATO accession process over the civilian control of the army, and a broad consensus among the elites on major political, economic, and foreign policy goals facilitated the consolidation of Polish democracy. Furthermore, the EU's political conditionality and demands concerning the alignment of Poland's legal, administrative and judicial structures with the EU acquis generated a significant incentive for the acceleration of the consolidation process. In general, the convergent and parallel tracks of Europeanization and democratization became major assets for the postCommunist Polish democracy. Nevertheless, the EU's democratizing impact also involved important limitations as will be discussed later in this chapter.

The chapter will examine the democratizing effects of the European integration process for the consolidation of Poland's democracy. The integration process will be referred to as the period from the 1993 Copenhagen meeting until Poland's accession to the EU in 2004. Before moving to the consolidation period, the chapter will briefly discuss key features of Poland's transition to democracy ensuing the 1989 Round Table Agreements. Then, the dissertation's four-part definition of democratic consolidation will be utilized to assess how much the integration process was helpful for democratic consolidation. Finally, the concluding section will analyze the limits of the EU's democratizing power in the case of post-Communist Poland. 


\section{The Polish Transition to Democracy: A Peaceful but Revolutionary Regime}

\section{Change}

Poland's transition from a Soviet dominated communist political regime to a Western oriented democracy and market economy was an event with both domestic and international consequences. The rise of the Solidarity trade union, the failure of martial law, and the Round Table negotiations were key moments in the Polish political scene during the 1980s. The end of Soviet interventionism over the communist satellite countries in Central and Eastern Europe not only determined the pace and mode of the Polish transition but also paved the way for the end of the Cold War.

To a great extent, three major dynamics were responsible for the peaceful end of the communist regime in Poland: worsening economic conditions, the emergence and rise of the Solidarity movement, and non-interventionist policy of the Soviet Union.

Following the declaration of martial law in December 1981, Western governments and organizations, particularly the United States, applied economic sanctions to the Polish communist regime. One could argue that although these pressures were not decisive as much as the three dynamics above, they had some accelerating effects on deterioration of the economic situation. On the other hand, the European Community did not have any considerable role in the collapse of the communist regime. The EC's democratizing impact became visible in the early 1990s; however, it amounted to a significant level only after Poland's accession process to the EU was set in motion following the 1993 Copenhagen European Council meeting.

The peaceful end of the Polish communist regime in 1989 was revolutionary and unexpected. However, the origins of change dated back to the Solidarity led 1980-81 
crisis. The labor strikes and subsequent Gdansk Agreement in August 1980 were a turning point. For the first time, the workers had the right to strike and to form a trade union independent from the Communist Party, which was considered a vanguard of workers in the socialist system. In addition, the Polish party state conceded to the expansion of basic rights and the relaxation of censorship (Pravda 1982: 167, Rachwald 1990: 19, Goldman 1997: 219-22, Davies 2001: 15, Kemp-Welch 2008: 245-53, Paczowski et al 2009: 70-80). Major labor strikes before the summer of 1980 were not able to generate such concessions, although they resulted in important changes. The June 1956 and December 1970 strikes led to the change of leadership in the Communist partythe Polish United Workers Party-PZPR- following a serious repression on the labor. Worsening economic conditions (food shortages, lower salaries, i.e.) were the key reasons behind the labor unrest. The 1956 strikes resulted in the end of 'Polish Stalinism' (1948-56), and paved the way for the period of 'national communism' under the Gomulka rule (1956-70). The 1970 strikes resulted in leadership change too: Edward Gierek replaced Wladyslaw Gomulka as first secretary of the Communist party (Bernhard 1993: 152-60, Biskupski 2000: 124-46, Kemp-Welch 2008: 180-206). Particularly important, the Polish economy under the Gierek rule (1970-80) became highly dependent on Western credits. ${ }^{85}$

In contrast to the previous 1956 and 1970 strikes, the June 1976 strikes did not result in leadership change. However, the strikes and the subsequent repression generated a significant dynamic in the country: the emergence of a broad based opposition

\footnotetext{
${ }^{85}$ As a result of massive Western money borrowing under the Gierek rule, Poland became one of the most indebted countries of the Central and Eastern Europe by 1980 with an amount of $\$ 23$ billion (Gowan 1990: 64, Rachwald 1990: 47, Roszkowski and Kaufman 2006: 375-78).
} 
movement against the communist regime. In this regard, the establishment of the Workers' Defence Committee (KOR) in September 1976 was a key development.

Dissident intellectuals, formerly orthodox Marxists, became a key ally of the workers. In addition, the Catholic Church, if not explicitly, supported this alliance. The emerging opposition posed a serious threat to the legitimacy of the communist rule. The significance of such development became most visible in the outbreak of 1980-81 crisis. In the aftermath of the mid-August strikes and the Gdansk concessions, Polish politics witnessed the foundation of Solidarity and a change of Communist party leadership in September 1980. Stanislaw Kania replaced Gierek as Secretary General of the PZPR. However, Kania's term ended short due to a deepening economic crisis an growing legitimacy problem of the Communist rule. General Wojciech Jaruzelski replaced Kania in October 1981, outlawed Solidarity, and declared martial law on December 13, 1981.

The 1980-81 crisis was definitely a watershed event for the fate of Polish communism. On the one hand, the Solidarity labor movement with about ten million membership base emerged as a powerful force against the communist party state. Although the martial law policy (December 1981- July 1983) outlawed Solidarity, the movement survived underground. On the other hand, the 1980-81 crisis substantially demoralized and paralyzed the Communist party (Kemp-Welch 2008: 281, Rothschild and Wingfield 2008: 160). However, the Soviet Union under the leadership of Leonid Brezhnev was keen on not to allow a fissure in the Soviet dominated Eastern European countries. As many observers of Polish politics agreed, the imminent threat of Soviet intervention played a central role in Jaruzelski's decision to impose the martial law 
(Rachwald 1990: 21, Wiatr 1991: 13, Colomer 2000: 92, Paczkowski et al 2009: 139). As a result, Poles had to wait a few more years to witness the transition to democracy. The Solidarity led opposition, which was composed of different ideological orientations including social democrats, liberals, and Catholic nationalists, posed a serious challenge against the Communist party in the aftermath of 1980-81 crisis. Increasing economic problems and the Party's failure to address them as well as a growing legitimacy question led the country to a severe stalemate. In this context, foreign policy change in Mikhail Gorbachev's Soviet Union did have a decisive role for the shape of Poland's future. On the one hand, the end of the interventionist Brezhnev Doctrine strengthened the reformist wing of the Polish Communist Party vis-à-vis the conservatives/hardliners (Colomer 2000: 92). On the other hand, the end of the Soviet veto approach made possible and substantially influenced the pace and mode of the Polish transition to democracy, which was set in motion at the Round Table Negotiations of February-April 1989 (Bernhard 1990: 130 and 322, Kaldor 1990: 27, Hyde-Price 1996: 191, Goldman 1997: 228, Michnik 1998: 132).

The Polish transition has been identified as a 'self-limiting revolution', 'evolutionary revolution', or 'the Spanish way of transition' (Staniszkis 1984: 17, Ash 1984: 276, Michnick 1998: 124). These identifications underline two central features of the Polish path to democracy: (i) revolutionary but peaceful and gradual, and (ii) transition by agreement on the basis of mutual concessions. The Round Table talks, held between Solidarity and the Communist Party in the spring of 1989, ended with the following terms of concessions: (i) the legalization of trade unions including Solidarity (ii) holding semi-competitive elections for the Sejm (the lower house of the Polish 
Parliament) - $35 \%$ of seats were opened for full competition while $65 \%$ were reserved for the Communist Party- (iii) holding fully competitive elections for the Senate, and (iv) making the presidency a strong executive institution with an informal agreement for General Jaruzelski's election to the post (Barany and Vinton 1990: 192, Goldman 1997: 224, Friszke 2009: 132).

The Sejm and Senate elections in June 1989 resulted in a clear victory for the Solidarity led opposition while the Communist Party, which had had a monopoly of power in the past four decades, suffered a humiliating defeat. The Solidarity Civic Committee candidates won all the Sejm seats (161 out of 161), which were open for competition (35\%). In the fully competitive Senate elections, the Civic Committee succeeded in winning 99 seats out of 100 . The unexpected results certainly accelerated the pace of Polish transition to democracy. Following the elections, Jaruzelski was named president by the Sejm on July 19 in line with the Round Table concessions, while on August 24, Solidarity leader Tadeusz Mazowiecki became the first non-communist prime minister in Central and Eastern Europe after World War II (Barany and Vinton 1990: 192-200, Friszke 2009: 144-78). In December 1989, the Sejm changed the name of the state ("Third Polish Republic" instead of "People's Republic of Poland") through a constitutional amendment. The amendment also eliminated the references to Poland being a socialist state. In the next month, the Communist Party (PZPR) dissolved itself. Solidarity leader Lech Walesa was elected as the first non-communist president of the country in November 1990. In the aftermath of these key steps in the transition to democracy, post-communist Poland held the first fully competitive parliamentary elections in October 1991. Following O'Donnell and Schmitter definition of democratic 
transition, one could argue that the Polish transition was complete by the 1991 elections.

As a result, the years 1989-1991, from the Round Table talks to the first fully competitive elections, can be identified as the period of democratic transition.

For the democratic transition, two dynamics played the most decisive role: the emergence and rise of the Solidarity led opposition movement and the end of Soviet military intervention in the Central and Eastern European countries. The Round Table negotiations generated mutual concessions between Solidarity and the Communist Party which resulted in a gradual transition. Although one can note the significant role of elite level cooperation between the moderate wing of Solidarity leaders and the reformist section of the Communist Party, the labor centered opposition movement at the mass level made this cooperation possible. This is also confirmed by a key Solidarity figure Jan Kuron (1990: 74, Ekiert and Kubic 1999: 46) ${ }^{86}$ For the emergence of Solidarity, the Communist Party's failure in the economic realm was certainly important; however, the regime's monopoly of power (political, economic, and social) and the violations of human rights (repression in the 1970 and 1976 labor strikes, i.e.) had also significant impact on the rise of the opposition. Therefore, the authority crisis of the Polish Communist Party involved both economic and political dimensions (Wiatr 1991: 19, Rothschild and Wingfield 2008: 160-84).

The domestic origins of the Polish transition were centered upon the labor movement. However, one cannot understate the level of support the workers received through training, organizational and moral support from dissident intellectuals and the

\footnotetext{
${ }^{86}$ Jan Kuron, a key Solidarity figure, argued as follows: “...the roundtable talks marked a certain stage in the continuing struggle of the Polish people for democracy. But it became possible to reach this stage only after the enormous social activity in the legal days of Solidarity and the widespread clandestine resistance during the years of martial law" (Kuron 1990: 74).
} 
Catholic Church. Symbolically, the emergence of a powerful labor movement independent from the communist rule signified a key turning point, which was set through the 1980-81 crisis. In addition, the imminent threat of Soviet interventionism during the crisis certainly retarded the timing of democratic transition. With the critical shift in Soviet foreign policy under Gorbachev, the Solidarity led opposition and the Communist party were able to set the terms of the democratic transition through the Round Table talks.

At the international level, the Helsinki process of the Conference on Security and Cooperation in Europe (CSCE, 1973-75) enhanced Polish opposition in arguing against human rights violations of the communist regime, which was in fact a signatory of the Helsinki Final Act. On the other hand, the Western governments, particularly, the United States, applied economic sanctions following the imposition of martial law in December 1981, and these sanctions hampered to some extent the regime's ability to handle the worsening economic situation in the country. Furthermore, Pope John Paul's visits to Poland $(1979,1983,1987)$ provided important moral support for the Solidarity movement. Although these international factors played some roles in helping the opposition against the Communist Party, they were not consequential as much as the shift in the USSR's foreign policy.

The following table illustrates the key actors of the Polish transition at the individual, domestic, and international levels. 
Table 4.1: Key Actors in the Polish Transition

\begin{tabular}{|c|c|c|}
\hline & Authoritarian Status Quo & Support for the Transition \\
\hline Individual & Jaruzelski, during the $1980-81$ crisis & $\begin{array}{r}\text { Jaruzelski, during the } \begin{array}{r}1988-89 \\
\text { events }\end{array} \\
\text { Lech Walesa }\end{array}$ \\
\hline Domestic & $\begin{array}{r}\text { The Communist party (PZPR) during the } \\
1980-81 \text { crisis } \\
\text { Hardliners in the PZPR during the } 88-89 \\
\text { events }\end{array}$ & $\begin{array}{r}\text { Solidarity/Workers } \\
\text { Dissident Intellectuals } \\
\text { The Catholic Church } \\
\text { Moderates in the PZPR during the } \\
\text { 88-89 events }\end{array}$ \\
\hline International & $\begin{array}{r}\text { The Soviets in the } 1980-81 \text { crisis } \\
\text { (interventionist policy) }\end{array}$ & $\begin{array}{r}\text { The Soviets in the } 1988-89 \text { events } \\
\text { (indirectly, with non- } \\
\text { interventionist policy) } \\
\text { The United States }\end{array}$ \\
\hline
\end{tabular}

The European Community did not have any considerable role in the collapse of the communist regime in Poland. In June 1988, the Community established diplomatic relations with the COMECON countries including Poland. The overall response of the EC towards the 1989 events was slow. The Union was reluctant to give any prospect for EC membership, which was enthusiastically desired by the post-communist regimes to realize the strategic goal of "Return to Europe". In the years 1989, 1990, and 1991, the EC focused more on economic transition of these countries and played a coordinating role in the aid efforts of Western governments and international organizations. In this 
regard, one should note that the Western actors including the EC made economic aid to the post-communist countries conditional upon progress in economic reforms and the transition to a market economy (Ners 1993: 78-9, Smith 2001: 32-36). The democratic transition remained to a great extent in the shadow of the economic transition in the early 1990s.

Although limited, the emerging Polish democracy benefited from its European neighborhood in three important ways during the transition period. First, the EU-Poland associate agreement ("Europe Agreement") was set conditional upon five elements: the rule of law, human rights, multi-party system, free and fair elections, and market economy. ${ }^{87}$ Second, the EC's aid programme (PHARE- initially for Poland and Hungary, later extended to other CEE countries) included some funds for the promotion of democracy. Third, the Council of Europe membership (November 1991) and the ratification of European Convention on Human Rights (January 1993) set a favorable external ground to improve human rights standards in the country. The Council membership was only possible after fulfillment of the first fully competitive parliamentary elections in October 1991. The EU's democratizing role would become more visible in the aftermath of the June 1993 Copenhagen European Council meeting, as the latter launched the accession process for candidate countries that meet certain conditions, including political criteria.

\footnotetext{
${ }^{87}$ The associate agreement was signed on December 16, 1991; it came into force on February 1, 1994.
} 


\section{The Consolidation Process and the Democratic Impact of European Integration}

The completion of the democratic transition in a few years after the Round Table negotiations was an important step; however, the Polish democracy needed further progress in various realms in order to be consolidated. In the consolidation process, the European Union played accelerating, anchoring, and reinforcing roles through the policy

of democratic conditionality. The EU explicitly set fulfilling the Copenhagen political criteria as a requirement to launch the accession negotiations. With the help of the Copenhagen conditionality, monitoring, and accession funds, the EU did have a substantial leverage over key economic and political reforms in Poland during the period of negotiations (1998-2002).

In assessing the democratic impact of the European Union for post-communist Poland, a few important remarks should be made. First, the EU's influence was not uniform across three periods: 1989-1992, 1993-1997 (pre-negotiations), and 1998-2004 (negotiations and ratifying the Accession Treaty). While the EU-Poland relations lacked the prospect for full membership in the early 1990s, the relations experienced a significant transformation in the pre-negotiation years (1993-1997), and particularly in the years of accession negotiations (1998-2002). Therefore, the EU's democratizing impact evolved over the 1990s in parallel with the changing intensity of EU-Poland relations. Second, the EU's democratizing impact was possible only when Poles and the Polish political parties provided an overwhelming support for the cause of EU membership. Third, the EU's impact was not always positive. As the author's interviews 
with Polish political and intellectual elites confirm, the European integration process also generated some negative effects for the Polish democracy.

In the following section, the democratic impact of European integration will be examined in line with the four-part definition of democratic consolidation in the dissertation: (i) free, fair, competitive elections with universal suffrage, (ii) protection of fundamental rights and liberties including human and minority rights, (iii) high prospects of regime survival and civilian control of the military, and (iv) legitimacy, anti-system parties, stateness. After the examination of the EU's impact on each of four components, the chapter will conclude with a discussion on the limits of the EU's democratizing leverage.

\section{Free, fair, competitive elections with universal suffrage; no politically significant group should be excluded from electoral competition.}

Except for the semi-competitive founding elections of June 1989, post-communist Poland fulfills the first component of democratic consolidation. ${ }^{88}$ The 1991, 1993, 1997, and 2001 parliamentary elections along with the 1990, 1995 and 2000 presidential elections were all free, fair and competitive. Particularly notable, incumbent political parties never won in parliamentary elections between 1991 and 2001, while Polish elections always witnessed peaceful transfer of power between the Solidarity/postSolidarity and the post-Communist political parties (Millard 1999: 77).

\footnotetext{
${ }^{88}$ One also should note that the 1990 presidential elections, the first direct presidential elections in the history of Poland, resulted in the presidency of Solidarity leader Lech Walesa replacing the former communist, General Wojciech Jaruzelski. Therefore, the 1990 presidential elections should be considered as a turning point in the Polish transition.
} 
For the period of 1993-2004, the European Union accession process, particularly the Copenhagen political criteria played an anchor role for upholding free, fair, and competitive elections. Unlike the period of 1989-1992, the EU provided a clear prospect for membership to Poland after the June 1993 Copenhagen European Council meeting, and this prospect generated a powerful incentive for democratization. The European Commission's Opinion on Poland's Application for Membership (1997) confirmed that Poland met the Copenhagen political criteria ${ }^{89}$, which had been set as an explicit condition for the accession negotiations to be launched. Later, the Commission's annual progress reports from 1998 to 2003 monitored the Polish democracy, and were satisfied with Poland's record in the area of the political criteria. ${ }^{90}$ As confirmed by the EU's progress reports, Poland successfully upheld democratic elections. Neither the Polish democracy had any considerable problem nor did the EU exercise any specific, direct impact in this area, different from an anchor role in the accession process. The 2001, 2002, and 2003 progress reports did have a brief evaluation on the amendment to the Act on Political Parties (adopted in April 2001). The amendment made state funding as the major component of the incomes of political parties (Szczerbiak 2007: 315-6). The EU expected positive consequences of the amendment for transparent working of the political system. Although the major drive behind the amendment was curbing corruption, it also helped equalizing parties' access to the electoral process. As a result, the amended law also contributed to competitiveness of the democratic elections.

\footnotetext{
${ }^{89}$ The political criteria: "membership requires that the candidate country has achieved stability of institutions guaranteeing democracy, the rule of law, human rights, and respect for and protecting of minorities" (The 1993 Copenhagen European Council).

${ }^{90}$ Full text of the annual progress reports are available in the website of the EU: http://ec.europa.eu/enlargement/archives/enlargement_process/past_enlargements/eu10/poland_en.htm
} 
Among the interviewees whom the author talked to in Poland in September and October 2009, none of them discussed problems in the execution of democratic elections. ${ }^{91}$ A group of academicians from the Warsaw School of Economics expressed opinions that the EU monitoring on party financing was helpful.

\section{The protection of fundamental rights and liberties}

The Solidarity-led Polish transition was about not only having political competition through democratic elections, but also eliminating the violation of basic rights and freedoms experienced during the 1981-83 martial law period. The Round Table agreements and the 1989-1990 amendments to the 1952 constitution provided guarantees for judicial independence, and made the constitution closer to a liberal democratic entity (Howard and Brzezinski 1998: 134). In 1991, Poland adopted the European Convention on Human Rights and Fundamental Freedoms (ECHR), which was required by the Council of Europe for membership. ${ }^{92}$ At this time, Poland also accepted the legal powers of the European Court of Human Rights. As a reflection of progress in the realm of human rights, the OSCE opened the Office of Democratic Institutions and Human Rights in Warsaw in 1992. With the clear prospect for EU membership, provided in June 1993 if Poland achieved "stability of institutions guaranteeing democracy, the rule of law, human rights, and respect for and protecting of minorities", the second component of democratic consolidation found a more fertile ground.

\footnotetext{
${ }^{91}$ For the list of interviewees, their affiliations, and the dates of interviews, see Appendix 3. In his field study in Poland, the author used same set of interview questions as those in Spain (Appendix 1).

${ }^{92}$ The ECHR entered into force in Poland in 1993.
} 
A significant missing element in this realm until October 1997 was the lack of a post-Communist democratic constitution providing guarantees for the protection of human and minority rights. Although the rulings of Polish Constitutional Tribunal, the ECHR, and the Office of Civil Rights Ombudsman had helped somewhat, the 1997 constitution marked a fundamental step by providing such explicit guarantees (ZirkSadowski 1998: 1999-200). The second chapter in the constitution (articles 30 through 86) contains arrangements protecting personal freedoms and rights, political freedoms and rights as well as economic, social and cultural freedoms and rights. ${ }^{93}$ Articles 79 and 80 give citizens the right to apply to the Commissioner for Citizens' Rights and to the Constitutional Tribunal for assistance in protection of his/her freedoms and rights. Article 35 secures the right of minorities to maintain their languages and cultures, and Article 85 allows for conscientious objection. Finally, Article 91 guarantees the binding authority of international agreements in the Polish legal system. As a result, international human and minority agreements that Poland ratifies acquired constitutional protection. With all these features, the 1997 constitution marks a significant development for the second component of democratic consolidation.

Poland's integration with European institutions in the post-Communist period set a favorable international environment for the protection of basic rights and freedoms, as well as for establishing better human and minority rights standards. As mentioned earlier, Poland adopted the European Convention on Human Rights to join the Council of Europe in November 1991, and ratified it in January 1993 (Danchin 2002: 172). In May 1993,

\footnotetext{
${ }^{93}$ Full-text of the constitution is available at the website of the Polish Parliament (Sejm): http://www.sejm.gov.pl/prawo/konst/angielski/kon1.htm
} 
Poland recognized the right of its citizens to apply individually to the European Court of Human Rights (Zirk-Sadowski 1997: 118). The Europe Agreement (signed in December 1991), which established an associate relationship between Poland and the European Community, did have an explicit conditionality regarding respect for human rights (Smith 2001: 38, Pinder 1997: 114). ${ }^{94}$ The Helsinki Foundation for Human Rights, an European NGO based in Warsaw, helped Poland in its process of constitution-making. ${ }^{95}$ For instance, the Helsinki Foundation prepared Lech Walesa's draft bill of basic rights for the constitution. In addition, the Council of Europe's legal experts made a detailed review of all areas of Polish legislation to ensure congruence with the European Convention of Human Rights (Halmai 1995: 154-5, Kurczewski 1995: 133, Cwiek-Karpowicz and Kaczynski 2006: 37-39).

In sum, during 1993-2004, the European Union provided an increasing amount of assistance to the post-Communist Polish democracy as regards to the second component of democratic consolidation. In several ways, the EU contributed to the promotion of standards of human and minority rights.

First, the Copenhagen political criteria along with the clear prospect for full membership made human and minority rights an essential part of Poland's preparations to join the EU. The European Union asked Poland to ratify the Council of Europe's European Convention for the Prevention of Torture, European Framework Convention for the Protection of National Minorities, and the European Charter for Regional or

\footnotetext{
${ }^{94}$ The agreement set five conditions for Poland: the rule of law, human rights, multi-party system, free and fair elections, and market economy.

${ }^{95}$ The website of the Helsinki Foundation: http://www.hfhrpol.waw.pl/en
} 
Minority Languages. In addition, the EU required ratification of the ECHR and its additional protocols as a part of the EU acquis (article F.2 of the Maastricht Treaty). ${ }^{96}$ Although the issue of death penalty was highly controversial among the Polish people and political parties, the ECHR's Protocol 6 -abolition of death penalty in peacetimewas ratified on April 14, 2000 to align with the EU acquis (Vermeersch 2009: 174-7, Zirk-Sadowski 1997: 118, Fierro 2003: 140).

Second, the EU's monitoring of democracy and human rights through the annual progress reports generated an important dynamic to move Poland closer to European standards of human and minority rights. Each progress report evaluated the degree to which Poland met the Copenhagen conditionality rules including the political criteria. In the section on the political criteria, the reports reviewed important developments in the past year in two areas: (i) democracy and the rule of law, and (ii) human rights and the protection of minorities. While the first area was composed of four sections (the parliament, the executive, the judicial system, and anti-corruption measures), the second area included three parts: (i) civil and political rights (ii) economic, social and cultural rights, and (iii) minority rights and the protection of minorities. ${ }^{97}$ In preparing the progress reports, the European Commission consulted not only with the EU institutions

\footnotetext{
${ }^{96}$ Article F.2 in the Treaty of Maastricht: "The Union shall respect fundamental rights, as guaranteed by the European Convention for the Protection of Human Rights and Fundamental Freedoms signed in Rome on 4 November 1950 and as they result from the constitutional traditions common to the Member States, as general principles of Community law". Full-text of the treaty is available at: http://www.eurotreaties.com/maastrichteu.pdf. The EU's annual progress reports (1998-2003) included an annex table to show whether the CEE candidate countries including Poland ratified the ECHR and its main protocols. For example, see p.155 in the 2002 report, which is available at: http://ec.europa.eu/enlargement/archives/pdf/key_documents/2002/pl_en.pdf

${ }^{97}$ For example, see pages 8-13 in the 1998 Report, "Regular Report from the Commission on Poland's Progress Towards Accession". It is available at: http://ec.europa.eu/enlargement/archives/pdf/key_documents/1998/poland_en.pdf
} 
including the Council and the Parliament but also with the Council of Europe, the OSCE, and the Polish government. In addition, the reports benefited from the views of international and Polish NGOs.

All annual progress reports from 1998 to 2003 along with the 1997 Commission Opinion on Poland's Application for Membership of the European Union ${ }^{98}$ found that Poland met the political criteria, which was the requirement for the accession negotiations to be launched. In spite of the overall tone of satisfaction, the reports also brought several criticisms and set several tasks to be handled in regard to basic rights and freedoms, human rights and minority rights. As discussed earlier, ratification of the ECHR and its main protocols was set as a prerequisite for EU membership. In addition, the reports monitored whether Poland ratified the following international conventions: European Convention for the Prevention of Torture, International Covenant on Civil and Political Rights (ICCPR), Convention against Torture (CAT), Convention on the Elimination of All Forms of Racial Discrimination (CERD), Convention on the Elimination of All Forms of Discrimination against Women (CEDAW), and Convention on the Rights of the Child (CRC). Moreover, the reports pointed to several problems in order for Poland to improve its record before the accession. These problems included freedom of press, prison conditions, death penalty, detention period, custody conditions, discrimination against Roma people, fight against corruption, and the efficiency of judiciary. Although Poland's efforts to deal with these problems did have domestic

\footnotetext{
${ }^{98}$ Brussels, 7.15.1997. The Commission Opinion is available at: http://ec.europa.eu/enlargement/archives/pdf/dwn/opinions/poland/po-op_en.pdf
} 
origins, the EU accession process, particularly the Copenhagen conditionality, provided a significant incentive for further improvement. ${ }^{99}$

Third, the EU accession process, particularly the Copenhagen conditionality enhanced the hand of Polish civil society in favor of human and minority groups (Vermeersch 2009: 177). As the former Prime Minister Josef Oleksy stated in his response to the author's interview questions, the accession process empowered the society vis-à-vis the state, and it made the state more responsive to citizens' rights. ${ }^{100}$ Many other interviewees whom the author contacted in Poland in September and October 2009 discussed the ways in which the EU accession process contributed to Polish democracy in regard to the second component of democratic consolidation. ${ }^{101}$ For the basic rights and freedoms, many interviewees from Polish universities, the bureaucracy, and think tanks, confirmed that the EU accession process was very helpful. ${ }^{102}$ The Warsaw University professor Cezary Zoledowski argued that the EU accession process helped the institutionalization of minority rights. In addition, he stated that the death penalty was prohibited under direct pressures from the EU while the majority of Polish society was in favor of death penalty. Pawel Poncyljusz (Member of Parliament from the

\footnotetext{
${ }^{99}$ The EU also set the pre-accession financil assistance (PHARE, ISPA, and SAPARD funds) to the CEE candidate countries including Poland conditional upon satisfying the Copenhagen criteria. For example, see Accession Partnership 1999: Poland. (It is available at:

http://ec.europa.eu/enlargement/archives/pdf/dwn/ap 02 00/ap pl 99 en.pdf) In regard to the EU's human rights conditionality for the candidate countries, see Fierro 2003: 135-55.

${ }^{100}$ The author's interview with J. Oleksy in Warsaw on October 24, 2009. Oleksy served as Prime Minister from 1995 to 1996.

${ }^{101}$ For the list of interviewees, see Appendix 3.

${ }^{102}$ For example, interviews with Mieczyslaw Szostak (Warsaw School of Economics), Ageta Dziewlska (University of Warsaw), Leszek Jesien (Polish Institute of International Affairs), an anonymous official from the Polish Information and Foreign Investment, Franciszek Golembski (University of Warsaw), and Rafael Dymek (Schuman Foundation).
} 
right wing Law and Justice Party-PiS) agreed that the EU accession process enhanced the voices of minorities in the country. Maciej Duszczyk, Warsaw University professor and member of the Polish team for the EU accession negotiations, underlined the EU's positive role for the rights of sexual minorities (gays, lesbians i.e) and women. Malgorzata Mizerska, professor of international relations at the Warsaw University, agreed with Duszczyk, and added the rights of handicapped people to the EU's positive effects. Klaus Bachmann from the Warsaw based Stefan Batory Foundation argued that the EU accession process improved minority and consumer rights.

Several interviewees noted that the Council of Europe's European Court of Human Rights played more important role than the EU accession process in regard to human rights. M.Mizerska, K.Bachmann and Marek Ostrowski (foreign affairs editor of the weekly Polityka Magazine) expressed this view. L. Jesien, F. Golembski, and K. Bobinski (the Unia \& Polska Foundation) argued that the issue of minority rights was not a problem area during the EU accession. According to an anonymous official from the Office of the Committee for European Integration (UKIE), basic rights and freedoms in Poland were already present before the beginning of the accession process.

\section{High prospects of regime survival \& civilian control of the military}

In contrast to the democratic transitions in Latin America and Southern Europe, the civilian control of the military never posed a serious threat for the consolidation of Polish democracy due to distinctive nature of the post-Communist transitions. ${ }^{103}$ Although the civilian control of the army was not a fundamental challenge for

\footnotetext{
${ }^{103}$ For a theoretical and conceptual discussion on the civil-military relations in the post-Communist countries, see Barany 1993: 425-41, Cottey et al 2002: 1-17, Edmunds et al 2003: 1-22, Yaniszewski 2004: 19-38.
} 
consolidation, post-Communist Poland had to handle several problems in this realm during and after the transition period (1989-1991). Particularly notable, the country faced two important crises in this area in 1992 and 1994. The enactment of the Ministry of Defense Act, and Aleksander Kwasniewski's election to the Presidency (both in December 1995), the 1997 constitution, and the NATO accession process (1994-99) represented milestone developments for Poland's alignment with European standards for democratic control of the armed forces. By the time of the EU-Poland accession negotiations (1998-2002), the Polish democracy met the third component of democratic consolidation to a great extent. As a result, civilian control of the army never became a problem during the period of accession negotiations. Yet, the EU's democratic conditionality, which requires the civilian control of the military for both the EU candidate and the member states, played an anchor role.

This part of the chapter will first examine the civil-military relations before and during the period of Poland's democratic transition. Then, it will discuss key military reforms undertaken in the first two years of the transition (1989-90). Next, the 1992 and 1994 crises of civil-military relations will be analyzed in the context of further reform efforts in this area. After that, the section will evaluate the relative significance of Poland's bid for NATO membership for the civilian control of the army vis-à-vis the role of the EU accession process. In assessing the comparative salience of the NATO and EU accession processes, the section will also benefit from the author's field study in Poland.

During the Soviet dominated communist Poland (1945-1989), two major dynamics shaped the civil-military relations. First, the Warsaw Pact under the leadership of the Soviet Union limited to great extent the autonomy of the Polish military. As 
demonstrated in General Jaruzelski's decisions to declare martial law in 1981 and to launch the Round Table agreements in 1989, the Soviet Union played a central role in Polish politics. Hence, the civil-military relations in this period could only be analyzed in the context of the Communist alliance system.

Second, the Communist regime required total subordination of the military to the Communist Party (Gogolewska 1996: 62, Oliveira 1998: 17, Michta 2002: 168). ${ }^{104}$ The Party exercised its control over the military through several ways: (i) the head of the Party was also commander in chief (ii) the Party directly controlled the Main Political Administration in the army (iii) Communist Party membership was set for military officers as a prerequisite for professional development; hence, eighty percent of professional cadres were member of the Communist Party (iv) Marxist-Leninist indoctrination in all levels of the military education system, and (v) a Communist youth organization in the military (Johnson et al 1980: 40-44, Barany 1993: 426-30). The subordination of the military to the civilians during the communist period set a favorable context for Poland's democratic transition and consolidation processes.

After acknowledging the two major dynamics of civil-military relations during the communist era, one can expect no fundamental threat from the military when the transition to democracy was set in motion. The gradual character of the Polish transition, as shaped by the Round Table agreements, shaped the military's response to the postCommunist period. The agreements postponed major decisions in relation to the civilmilitary relations and national security strategy, except the following concessions by the

\footnotetext{
${ }^{104}$ General Jaruzelski's declaration of martial law in December 1981 was not against the Communist regime; rather, it was done to save the Communist rule in the country. Therefore, the martial law imposition was not a coup d'etat in the sense that it happens in authoritarian regimes (Michta 1990: 15-16, Kaminski 1993: 79, Davies 2001: 317).
} 
Solidarity: the presidency and four key ministries including the defense and the interior remained in communist hands while the presidency did get the central role in regard to military and foreign affairs (Asmus and Szayna 1991: 2). Moreover, General's Jaruzelski's election to the post of the presidency, and his close cooperation with the Solidarity Prime Minister Mazowiecki, made the military's support to the democratic transition much easier. As a result, the military did not pose a serious challenge against the transition process, and it remained under civilian control (Oliveira 1998: 25-28, Gogolewska 1996: 67).

In 1990, significant changes happened in the area of civil-military relations. In January, all Communist party cells were abolished in the military. In the spring, two Solidarity figures were appointed as civilian deputy defense ministers while the commander of the Polish General Staff Academy invited Solidarity intellectuals for a debate about military and security issues. From July to November, massive replacements of military personnel occurred after retirement of many older generals. ${ }^{105}$ The Main Political Administration was transformed from a Communist ideological unit to educational and psychological counseling body. The Ministry of Defense accepted the legislation prohibiting all political activities in the military. In addition, increasing numbers of civilians began to occupy positions in the military and the defense ministry. Moreover, the establishment of the Parliamentary (Sejm) and Senate Commissions of National Defense helped to generate an open debate about the military's budget. Finally, the military's name became the Polish army like in the interwar years, instead of the Polish People's Army (Szayna 1991: 16-36, Kurylowicz 1993: 82-4, Oliveira 1998: 31,

\footnotetext{
${ }^{105}$ More than 22,000 military officers including 57 generals and 1,300 colonels left the army between 1989 and 1994 (Gazeta Wyborcza April 21, 1994 cited in Michta 1997: 85).
} 
Latawski 2002: 21-3). In spite of all these important changes, the Ministry of Defense remained under the leadership of a military general until Lech Walesa appointed the first civilian minister of defense after the October 1991 elections. ${ }^{106}$

For establishing civilian control of the Polish military, the period of 1989-1992 was critical not only for deindoctrination of the Communist ideology and depoliticization of the military, but also for fundamental shifts in Poland's security doctrine and foreign policy. In Defense Doctrine of the Republic of Poland (dated July 21, 1990), Poland's national security was still linked with the Warsaw Pact although the Polish military officials were eager for the withdrawal of Soviet troops from the country. The Polish government announced in January 1991 that Poland would withdraw from the Warsaw Pact by July 1991. The dissolution of the Warsaw Pact in July 1991 and the withdrawal of Soviet troops from Poland by the end of 1992 facilitated the move of Poland's security and foreign policy in an Euro-Atlantic direction. As a result, memberships in the NATO and EU were set as "Poland's strategic goal" in Principles of Poland's Security Policy and Defence Strategy (dated November 2, 1992). ${ }^{107}$ Particularly notable, the emerging consensus on pro-Western foreign and security policy orientation among Solidarity, the former Communists, and the military in this period made the civilian control much easier.

The communist legacy of the civilian control of the military, the gradual character of the democratic transition, and the emerging consensus on a pro-Western foreign and security orientation played major roles for the fact that the Polish military did not pose a

\footnotetext{
${ }^{106}$ The Communist control of four key ministries including the defense and the interior ended after the October 1991 elections.

${ }^{107}$ Appendix section in Kuzniar 2001 provides key official documents concerning Poland's security and foreign policy in the 1990s (pp.539-590).
} 
considerable challenge to the post-Communist Polish democracy. The country never experienced a risk of a military coup in the critical period of early 1990s. Nonetheless, there were some occasional problems in the area of the civil-military relations until the enactment of the Ministry of Defense Act by then the newly elected president Aleksander Kwasniewski in December 1995. Particularly notable, the country witnessed two major crises concerning the civilian control of the military in 1992 and 1994.

In the so-called Parys affair, the conflict between President Walesa and Jan Parys (Poland's first civilian defense minister) for control over the army resulted in parliamentary inquiry that finally led to Parys's resignation from his post in May 1992. In response to the minister's "decommunizing" efforts in the military (through dismissal of senior officers), Walesa sided with the General Staff. The Walesa-Parys conflict was also related to the fight between Walesa and the Olszewski government in regard to defense ministry and the armed forces. Uncertainty in the legislative-executive relations, stemming from the lack of clear constitutional rules, played a major role in the outbreak of this crisis. Although the constitutional amendment in October 1992 ("the Little Constitution") clarified some ambiguities in the legislative-executive relations, Poland continued to have some troubles in the area of civilian control of the military for a few more years (Vinton 1995: 44-55, Gogolewska 1996: 68, Michta 1997: 81-85, 2002: 170).

In the September 1994 Drawsko crisis, the Chief of Staff Tadeusz Wilecki (appointed by Walesa after Parys's resignation) and a number of generals declared a vote of no confidence in the defense minister Piotr Kolodziejczyk when they were at a dinner with President Walesa and the defense minister at the army's Drawsko ground in Warsaw. Later, the parliamentary inquiry found the military generals responsible, and 
asked the president to reprimand them. However, Walesa dismissed the defense minister, and avoided taking any disciplinary action against the Drawsko generals; hence, the president worked against the parliament's recommendation for affirming the civilian control of the military. According to former deputy defense minister (1990-93) and current President Bronislaw Komorowski, the Drawsko affair not "assumed the nature of a military coup, but this does not mean its seriousness should be underestimated"' (Simon 2004: 38). Later, Walesa asserted in the parliament in January 1995 that he would support any legislative effort to enhance the authority of Chief of Staff vis-à-vis the defense minister. In June 1995, Walesa vetoed the Ministry of Defense draft law, which required a complete subordination of the Chief of Staff to the civilian defense minister (Oliveira 1998: 33, Michta 1997: 91-3, 2002: 170, Latawski 2002: 28-30, Dutkiewicz 2004: 84-5).

The Parys and Drawsko affairs did not pose a threat to Poland's democracy to the extent of a military coup; however, they demonstrated the need for reform in the realm of democratic pattern of civil-military relations. President Walesa's taking side with the military against the government and the parliament was definitely related to the existing legislative gap in relation to the civilian control of the military. Walesa's personal ambitions for power played an important role in the outbreak of these crises. The ratification of the Ministry of Defense (MoD) Act in December 1995 by President Aleksander Kwasniewski represented a milestone development for the increasing civilian control over the military. The MoD Act defined twenty-three prerogatives of the defense minister, and made the Chief of Staff directly responsible to the minister. As a result, the Act eliminated any possibility that the president may claim a special prerogative over the senior military (Michta 2002: 170-71, Dutkiewicz 2004: 87-9). Furthermore, the 
constitution of Poland (adopted in October 1997) explicitly states that the defense minister does have a right of command over the military in times of peace (article 134). As a result, the 1995 MoD Law and the 1997 constitution clarified the previous legal ambiguities in the area of civil-military relations, and enhanced the civilian control of the military. Poland's increasing contacts with NATO since 1994, and the subsequent accession process accelerated the country's alignment with the Western norms of civilmilitary relations. The following section examines NATO's contribution, and then assesses the EU's role in this area.

Poland's NATO and EU Accession Processes and the Civilian Control of the Military

Although the first non-Communist government aimed at shifting the country's external direction towards Euro-Atlantic structures, Poland's foreign and security policy remained to a great extent highly sensitive to changes in the Soviet Union in the period of democratic transition (1989-91). Only after the collapse of the Warsaw Pact in 1991 and the withdrawal of Soviet military troops by the end of 1992, post-communist Poland began to follow an independent course in its foreign and security policy. As a reflection of this change, NATO and EU memberships were set as Poland's strategic goals for the first time in November 1992. ${ }^{108}$ By the autumn of 1993, the country's political and military elite reached an overwhelming consensus on Poland's integration to NATO and EU (Vinton 1995: 23-24, Balcerowicz 2001: 448, Zawistowska 2001: 554, Kuzniar 2009: 9).

${ }^{108}$ Principles of Poland's Security Policy and Defence Strategy (November 2, 1992). 
Poland's participation in NATO's Partnership for Peace (PfP) program in 1994 was a turning point for the bilateral relations. On the one hand, the PfP program was highly effective to prepare the Polish army for NATO membership in several areas, such as command and control defense planning, standardization, infrastructure, and training. The military officers including senior generals did have ever-increasing contacts with their counterparts in NATO states (Balcerowicz 2001: 451, Cwiek-Karpowicz et al 2006: 45). On the other hand, Poland's increasing contacts with NATO through the PfP and the subsequent accession process required Poland's alignment with NATO's conditionality regarding democratic control of the military. In this regard, NATO set four explicit conditions for membership: (1) a clear division of authority between the president and government (prime minister and defense/interior minister), (2) parliamentary oversight of the military through control of the defense budget, (3) peacetime government oversight of general staffs and commanders through civilian defense ministries, and (4) restoration of military prestige, trustworthiness, accountability, and operational effectiveness (Simon 2000: 39-40). When Lech Walesa vetoed the MoD draft law, which required the subordination of the general staff to the civilian defense minister, in June 1995, NATO sent a strong message that Walesa's approach to the civil-military relations weakened Poland's prospect for membership (Michta 2002: 170-72). In spite of NATO's push, the ratification of the MoD Law was possible only after Walesa lost against Kwasniewski in the November 1995 presidential elections. The NATO accession process (1994-99), particularly the accession talks (September to November 1997) not only moved the Polish 
military towards NATO standards of operations and training but also resulted in Poland's further alignment with the democratic control of the armed forces. ${ }^{109}$

Although post-Communist Poland experienced some problems in the area of civilmilitary relations until the end of 1995, the enactment of the MoD Law by then the newly elected president Kwasniewski in December 1995 and the 1997 constitution reduced the previous uncertainties in relation to the civilian authority over the military. Poland's bid for NATO membership, which received an overwhelming support from all major political forces including the military, became an integral part of the reform efforts regarding civilian control (Michta 2002: 175-6). As a result, the NATO accession process accelerated the reform effort. Later, Poland's NATO membership (since March 1999) played a reinforcing role in maintaining the democratic control of the armed forces. At the time when the EU-Poland accession negotiations were launched (March 1998), Poland did not have any considerable problem regarding the civil-military relations. As confirmed by the Commission Opinion on Poland's Application in July 1997, Poland met the Copenhagen political criteria, which also required the civilian control of the army. In the annual progress reports (1998-2003), the Commission continued to hold this assessment, and it did not have any discussion on the area of civilmilitary relations; rather, the reports only covered issues concerning Poland's participation in the EU's Common Foreign and Security Policy (chapter 27 of the EU acquis). ${ }^{110}$ Therefore, the EU accession process did not have any direct impact on the

\footnotetext{
${ }^{109}$ For the NATO accession process, see NATO Handbook, "Chapter 3: The Opening Up of the Alliance: The Process of NATO Enlargement".

(It is available online at: http://www.nato.int/docu/handbook/2001/hb030102.htm)

${ }^{110}$ For example, see the 2001 report, pages $96-98$ (The report is available online at: http://ec.europa.eu/enlargement/archives/pdf/key_documents/2001/pl_en.pdf)
} 
Polish civil-military relations. Yet, the EU's democratic conditionality, which was required for both the candidate and the member states, played a favorable anchor role for the effective implementation of the civilian control before and after membership.

The author's field study in Poland generated three major conclusions for the third component of democratic consolidation: (i) the civil-military relations did not pose a considerable challenge against the post-communist Polish democracy, (ii) the NATO accession process made more direct contributions than the EU accession process to solidifying civilian control of the Polish military, and (ii) the Polish democracy has not experienced any risk of democratic breakdown or authoritarian retreat initiated by the military. The first view was expressed by several people including Professor Golembski (Warsaw University), R. Dymek (the Schuman Foundation), Professor Malgorzata Mizerska (Warsaw University), Professor K. Bachmann (the Stefan Batory Foundation), a group of academicians from the Warsaw School of Economics, and an anonymous official from the European Integration Committee (UKIE). The second conclusion was conveyed in the interviews with L. Jesien (Polish Institute of International Affairs), Professor M. Szostak (Warsaw School of Economics), Pawel Poncyljusz (the Member of Parliament), Marek Ostrowski (foreign affairs editor of the Polityka Magazine), Professor Duszczyk (Warsaw University), and K. Bobinski (Unia and Polska Foundation). The third conclusion was confirmed by many interviewees including the former Prime Minister Josef Oleksy, Professor Bachmann, Professor Golembski, M. Ostrowski, P. Poncyljusz, Professor M. Szostak, Professor Mizerska, R. Dymek, Professor Duszczyk, Professor E. Lyskowska (Warsaw School of Economist), Professor C. Zoledowski 
(Warsaw University), the anonymous official from the UKIE, and a group of academicians from the Warsaw School of Economics.

\section{Legitimacy, anti-system parties, stateness}

The fourth component of democratic consolidation in this dissertation is related to the degree to which democratic regime receives support from people and the political elite. In consolidated democracies, democracy is considered as the most preferable type of political regime by the majority of people. In addition, no politically significant group or political party works for an alternative regime or seeks secession. Therefore, antisystem parties or separatist groups which draw a strong public support pose a severe challenge against the consolidation.

In this area of democratic consolidation, the Polish democracy did not suffer serious challenges in the period after the transition. The initial massive socio-economic costs of the shock therapy driven market reforms resulted in disappointments among people. This paved the way for some ambiguity about satisfaction with the development of democracy until the mid-1990s. Low trust in political institutions and low turnout rates in the elections also questioned the level of support that the post-Communist democracy received from the Polish people. Nevertheless, the majority of Polish people opted for multi-party democracy, and never looked for an alternative political regime. On the elite level, a wide consensus between the Solidarity and the post-Communist elites on democratization, market reforms, and pro-Western foreign policy orientation played an important role for the democratic consolidation. Finally, ethnic separatism was never a problem for the Polish democracy. 
European integration, which received an overwhelming support from the Polish people and political elite, made several contributions as regards the fourth component of the consolidation. First of all, the cause of European integration became a key part of the consensus among the Polish political elite. Second, the EU's push for administrative reforms in the pre-accession period enhanced the quality of Polish democracy in many areas, and it indirectly resulted in higher public support for the democratic regime. Finally, the EU's demands regarding human rights and de-centralization created more favorable environment for ethnic minorities in the country.

In this section of the chapter, the democratizing impact of European integration will be assessed in regard to the fourth component of democratic consolidation. In doing so, the section will also examine the degree to which the Polish democracy had problems regarding public legitimacy, elite consensus, anti-system parties, and stateness in the period of pre-accession (1993-2004). Overall, the attitudinal and behavioral support basis of the post-Communist Polish democracy will be examined in line with the EU accession process. In this regard, the section will also benefit from the author's field study in Poland.

\section{Public Legitimacy}

In the aftermath of the collapse of the communist regime, the Polish people provided a high level of commitment to democracy as a political regime. According to the New Democracies Barometer (1991-98), neither monarchy nor military rule as an alternative to democracy attracted any considerable support from Poles. ${ }^{111}$ For the years

\footnotetext{
${ }^{111}$ The New Democracies Barometer (NDB) was conducted by Christian W. Haerpfer in the twelve postcommunist countries. The NDB's longitudinal large scale and cross-national survey included 62,000 face to
} 
1994, 1996, and 1998, the military regime option found 11, 4, and 6 percent support among the people while support for the monarchy was at the level of 6 and 4 percent for 1994 and 1998 respectively. With regard to the question of approval for suspension of parliament and abolishment of parties, the polls showed about 70 percent disapproval rate. ${ }^{112}$ Responding to the question of whether restoring the former communist regime would be better, only 18,8 , and 14 percent provided support for the communist restoration in the years 1994, 1996, and 1998 respectively (Haerpfer 2002: 18-38). To complement the NDB poll results, the Warsaw-based CBOS poll showed approvingopposing democracy rates in the abstract of $61-17$ in $1995,71-12$ in 1996 , and $67-12$ in 1997 (Sanford 2002: 64).

Although there was no search for non-democratic regime by the majority, the Polish people rated quite favorably the performance of the former communist regime until the mid-1990s. ${ }^{113}$ In parallel with considerable level of nostalgia for the communist past, more than half of Poles were dissatisfied with the functioning of post-Communist Polish democracy between 1991 and $1994 .{ }^{114}$ In these years, there was also a

face interviews; 10,000 interviews per year in 1991, 1992, 1994, 1996, and 1998. (Haerpfer 2002: viii-x, 15)

${ }^{112}$ For the years 1991, 1992, 1994, 1996, and 1998, disapproving the suspension was at 67, 57, 71, 68, and 81 percent respectively. (Haerpfer 2002: 30)

${ }^{113}$ For the NDB poll question, "Here is a scale for ranking how the government works. The top, +100 , is the best; at the bottom, -100 , is the worst. Where on this scale would you put the former communist regime", the Polish people rated as follow: 34\%(1991), 42\% (1992), 38\%(1994), 25\%(1996), 30\% (1998) (Haerpfer 2002: 12).

${ }^{114}$ According to the Central and Eastern European Barometer (CEEB), the level of satisfaction with the development or the functioning of democracy for the years from 1990 to 1997 is as follow: very satisfied/fairly satisfied versus not very satisfied/not at al satisfied: 38-37 (1990), 27-50 (1991), 32-65 (1992), 35-49 (1993), 23-63 (1994), 50-38 (1995), 43-45 (1996), 57-33 (1997). The poll question: "On the whole, are you satisfied, fairly satisfied, not very satisfied or not at all satisfied with the way democracy is developing in your country?" (Plasser et al 1998: 87). 
considerable negative public perception about respect for human rights in the country. ${ }^{115}$ Nevertheless, more than sixty-percent of Poles provided their support (in 1994) for the systemic changes after $1989 .{ }^{116}$ As many observers of Polish politics suggested, a combination of a democratic transition and painful market reforms contributed to high levels of nostalgia for the communist past and also to wide dissatisfaction with the functioning of the post-communist democracy in the first half of the 1990s (Taras 1995: 194, Plasser et al 1998: 96, 117, Rose et al 1998: 115-9, Sanford 2002: 66-7). In addition, the Polish political parties and institutions acquired a very low level of public trust. Yet, the majority of Polish people opted for multi-party democracy, and maintained a high level of commitment to democracy as a political regime.

How did European integration have an impact on public legitimacy of the Polish democracy? First of all, one should note that Poles did have higher levels of trust in the EU institutions and democracy than in the Polish democracy and its institutions during the EU accession process. According to the 2003 CBOS poll, the Polish people perceived the EU institutions as more efficient, more honest, less corrupt and serving much better to public interests than the Polish institutions. ${ }^{117}$ In addition, the Polish people were more

\footnotetext{
${ }^{115}$ The difference between respect and non-respect answers in the polls for 1991, 1992, 1993, and 1994: -4, $-17,-19$, and -30 . The CEEB poll question: "How much respect is there for individual human rights nowadays in your country? Do you feel there is a lot of respect for individual human rights, some respect, not much respect, or no respect at all?"

${ }^{116}$ According to the Warsaw based CBOS poll: "In hindsight, was it worth changing the system in Poland X years ago?": percentages of yes for the years 1994, 1995, 1997, 1999, and 2001 was 62, 75, 70, 63, and 56 percent respectively (Gorniak et al 2004: 158). The October 1994 poll of Business Central Europe also showed a similar result: 69 percent approved the democratic regime while 38 percent approved the former communist regime (Taras 1995: 212).

${ }^{117}$ Public attitudes about Polish and EU institutions (CBOS 2003): "they are efficient" (7 versus 50 percent), "they are generally honest" ( 8 vs 51 ), "they are mostly corrupt" (78 versus 18 ), "they above all look after the interests of common people" (4 versus 39) (Gorniak et al 2004: 161).
} 
satisfied with the functioning of the EU democracy than their own. ${ }^{118}$ As a result, there was an overwhelmingly positive image of European integration among Poles in regard to democracy. Second, the European integration process indirectly affected Poles' attitudes towards democracy in their country. The EU's insistence on fighting corruption, and judiciary and public administration reforms during the accession negotiations pushed the Polish government to take faster action in these areas. For example, the Polish government launched an "anti-corruption' strategy in 2002, and these efforts were closely monitored through the EU progress reports. ${ }^{119}$ Moreover, modernizing aspect of the EU accession process set an important opportunity to enhance the economic performance of the country. On the one hand, the EU provided plenty of funds for modernization of infrastructure, development of the poorer regions, and civil society. On the other hand, Poland as a candidate country for EU membership was able to attract more foreign direct investment and to develop favorable environment for better economic performance. As a result, the prospective EU membership indirectly contributed to public perceptions of democracy, and made an authoritarian retreat a far more distant possibility.

The indirect contributions of the EU accession process in regard to public legitimacy were also observed in the author's field study in Poland. Several interviewees underscored the EU's help for transparency in public administration and fighting

\footnotetext{
${ }^{118}$ In Eurobarometer survey (February 2004) in Poland, satisfaction with Polish democracy was at 16 percent while EU democracy satisfied 45 percent of the respondents.

119 The European Union considered fighting against corruption as a part of the EU acquis in the realm of justice and home affairs. The EU's annual progress reports examined corruption under the acquis chapter of justice and home affairs (Chapter 24). For example, see the 2003 Report, pages 52-55. It is available online at: http://ec.europa.eu/enlargement/archives/pdf/key_documents/2003/cmr_pl_final_en.pdf
} 
corruption. ${ }^{120}$ The majority of interviewees noted that the EU made substantial assistance for the modernization of Polish infrastructure in particular, and for economic development in general. ${ }^{121}$ Some people argued that the EU accession process set limits for populist politicians as the process required extensive political and economic reforms to meet with the EU's membership conditionality. Then, the process helped political stability in the country. ${ }^{122}$ In addition, NGOs-civil society development and political participation were considered by some interviewees as important positive effects of the EU accession process. ${ }^{123}$

\section{Elite Consensus and Anti-System Parties}

Extreme fragmentation of party politics and institutional uncertainties over the legislative-executive relations posed important challenges for political stability in the first years of post-Communist Polish democracy. After the October 1991 elections, twentynine parties acquired seats in the parliament while each of the first two parties obtained only twelve percent of votes. After changes in the electoral law, such an extreme political fragmentation ceased to exist in the 1993, 1997, and 2001 elections. However, high elite turnover and coalition governments remained key features of Polish politics from 1989 to

\footnotetext{
${ }^{120}$ Interviews with M. Szostak, K. Starzyk, and A.Dziewlska

${ }^{121}$ Interviews with J.Oleksy, P.Poncyljusz, M. Ostrowski, M.Duszczyk, C.Zoledowski, F. Golembski, R.Dymek, M.Mizerska, D.Karwoth, E.Lyskowska, L. Jesien, two anonymous officials from the Office of the Committee for European Integration and the Polish Information and Foreign Investment Agency

${ }^{122}$ Interviews with C.Zoledowski, J. Oleksy, M.Szostak, and an anonymous official from the Polish Information and Foreign Investment Agency

${ }^{123}$ Interviews with K.Starzyk, K.Zakrzewska, J.Wiatrowska, and an anonymous official from the Polish Information and Foreign Investment Agency
} 
2004. In this period, incumbent political parties never achieved to maintain their power at the next elections, while coalition governments set the political scene. The communist successor parties won in the 1993 parliamentary elections; Lech Walesa lost the 1995 presidential elections to a former communist, Alexander Kwasniewski. In the 1997 and 2001 parliamentary elections, the Polish political scene again witnessed shifts in power between the right and the left. The electoral performance of political parties can be seen in Table 4.2. A list of Polish governments from 1991 to 2004 is provided in Table 4.3.

Table 4.2: Polish Parliamentary Elections (1991, 1993, 1997, 2001): Percentages of votes and number of seats in the Sejm.

\begin{tabular}{|l|l|l|l|l|}
\hline PARTIES & $\mathbf{1 9 9 1}$ & $\mathbf{1 9 9 3}$ & $\mathbf{1 9 9 7}$ & $\mathbf{2 0 0 1}$ \\
\hline Democratic Union-UD & $12.3 \%(62)$ & $10.6 \%(74)$ & - & - \\
\hline Democratic Left/SLD & $12 \%(60)$ & $20.4 \%(171)$ & $27.1 \%(164)$ & - \\
\hline $\begin{array}{l}\text { Democratic Left Alliance: SLD + } \\
\text { UP }\end{array}$ & - & - & - & $\begin{array}{l}41 \%(216) \\
(\mathrm{i})\end{array}$ \\
\hline Union of Labor-UP & $2.1 \%(4)$ & $7.3 \%(41)$ & $4.7 \%(0)$ & - \\
\hline Freedom Union- (UW) & - & - & $13.4 \%(60)$ & $3.1 \%(0)$ \\
\hline Solidarity & $5.1 \%(27)$ & $4.9 \%(0)$ & $-(\mathrm{ii})$ & - \\
\hline Solidarity Electoral Action-AWS & - & - & $\begin{array}{l}33.8 \% \\
(201)(\mathrm{ii})\end{array}$ & $5.6 \%(0)$ \\
\hline Christian National Union-ZChN & $8.7 \%(49)$ & $6.4 \%(0)$ & $-(\mathrm{ii})$ & - \\
\hline Centre Alliance-PC & $8.7 \%(44)$ & $4.4 \%(0)$ & $-(\mathrm{ii})$ & - \\
\hline Christian Democracy-ChDSP & $2.4 \%(5)$ & - & $-(\mathrm{ii})$ & - \\
\hline Non-Party Reform Bloc-BBWR & - & $5.4 \%(16)$ & $-(\mathrm{ii})$ & - \\
\hline Movement for the Republic-RdR & - & $2.7 \%(0)$ & $-(\mathrm{ii})$ & - \\
\hline Polish Peasant Party-PSL & $8.7 \%(48)$ & $15.4 \%(132)$ & $7.3 \%(27)$ & $9 \%(42)$ \\
\hline $\begin{array}{l}\text { Confederation Independent } \\
\text { Poland-KPN }\end{array}$ & $7.5 \%(46)$ & $5.8 \%(22)$ & - & - \\
\hline $\begin{array}{l}\text { Liberal-Democratic Congress- } \\
\text { KLD }\end{array}$ & $7.5 \%(37)$ & $4 \%(0)$ & - & - \\
\hline Peasant Alliance-PL & $5.5 \%(28)$ & $2.4 \%(0)$ & - & - \\
\hline Polish Beer-Lovers' Party-PPPP & $3.3 \%(16)$ & $0.1 \%(0)$ & - & - \\
\hline German Minority- MNSO & $1.2 \%(7)$ & $0.4 \%(4)$ & $0.4 \%(2)$ & $0.4 \%(2)$ \\
\hline $\begin{array}{l}\text { Movement for Autonomy of } \\
\text { Silesia }\end{array}$ & $0.4 \%(2)$ & $0.2 \%(0)$ & - & - \\
\hline Christian Democratic Party-PChD & $1.1 \%(4)$ & - & - & - \\
\hline $\begin{array}{l}\text { Movement Reconstruction of } \\
\text { Poland-ROP }\end{array}$ & - & - & $5.6 \%(6)$ & - \\
\hline
\end{tabular}




\begin{tabular}{|l|l|l|l|l|}
\hline Samoobrona: Self-Defence & - & $2.8 \%(0)$ & $0.1 \%(0)$ & $10.2 \%(53)$ \\
\hline Citizens' Platform-PO & - & - & - & $12.7 \%(65)$ \\
\hline Law and Justice (PiS) & - & - & - & $9.5 \%(44)$ \\
\hline League of Polish Families-LPR & - & - & - & $7.9 \%(38)$ \\
\hline Party X & $0.5 \%(3)$ & $2.7(0)$ & - & - \\
\hline Realpolitik Union-UPR & $2.3 \%(3)$ & $3.2 \%(0)$ & $2 \%(0)$ & - \\
\hline Others & $(15)$ & $(0)$ & $(0)$ & $(0)$ \\
\hline Total & 460 & 460 & 460 & 460 \\
\hline Turnout & $41 \%$ & $51 \%$ & $48 \%$ & $46 \%$ \\
\hline
\end{tabular}

Notes: i: Includes SLD (200) and UP (16) seats; ii: Member of the Solidarity Electoral Action (AWS); iii. Electoral threshold was five percent for parties (except minority parties), and eight percent for coalitions in the 1993, 1997, and 2001 elections.

Source: Rose and Munro 2009: 191-209, Castle and Taras 2002: 98-103

Table 4.3: Governments in Poland (1991-2004)

\begin{tabular}{|l|l|l|l|l|}
\hline Prime Minister & $\begin{array}{l}\text { Period } \\
\text { Served }\end{array}$ & $\begin{array}{l}\text { Nature of } \\
\text { Government }\end{array}$ & $\begin{array}{l}\text { Leaning of } \\
\text { Government }\end{array}$ & Reason for Change \\
\hline Jan Olszewski & $1991-92$ & Minority coalition & Right & No confidence \\
\hline Hanna Suchocka & $1992-93$ & Minority coalition & Centre-right & No confidence \\
\hline $\begin{array}{l}\text { Waldemar } \\
\text { Pawlak }\end{array}$ & $1993-95$ & Minority coalition & Centre-right & Resignation of PM \\
\hline Josef Oleksy & $1995-96$ & Minority coalition & Centre-left & Resignation of PM \\
\hline $\begin{array}{l}\text { Włodzimierz } \\
\text { Cimoszewicz }\end{array}$ & $1996-97$ & Minority coalition & Centre-left & Election \\
\hline Jerzy Buzek & $1997-00$ & Majority coalition & Centre-right & $\begin{array}{l}\text { Break-up of } \\
\text { coalition }\end{array}$ \\
\hline Jerzy Buzek & $2000-01$ & Minority coalition & Right & Election \\
\hline Leszek Miller & $2001-03$ & Majority coalition & Centre-left & $\begin{array}{l}\text { Break-up of } \\
\text { coalition }\end{array}$ \\
\hline Leszek Miller & $2003-04$ & Minority coalition & Centre-left & Resignation of PM \\
\hline
\end{tabular}

Source: Millard 2007: 41

In spite of fragmented party politics, frequent government changes, short-run coalition governments (especially until 1997), and the delay in the making of the first post-Communist constitution (April 1997), broad elite consensus between Solidarity and the communist successor parties on political and economic reforms made a significant 
contribution to the consolidation of Polish democracy. The political elite on the right and left spectrum of Polish politics also shared an overarching agreement on pro-Western foreign policy orientation in which the EU and the NATO memberships were set as bipartisan strategic goals. According to a 1996 study, which was based on interviews with 286 politicians including 215 parliamentary deputies from four major parties, both Solidarity and the communist successor parties considered democratic and market reforms as a necessity. Besides, they were quite similar in regard to conceptions of politics and attributions of democracy (Mark and Wesolowski 2000: 88-96). Although there were differences about the limits of presidential powers, the extent of welfare rights, and state-church relations, consensus on major goals created a highly favorable domestic dynamic for the consolidation of Polish democracy (Wasilewski 1998: 172, Higley and Lengyel 2000: 14). Particularly notable, the rapid transformation of the old communist elite was a great asset for a faster process of democratic consolidation in the country.

Only four years after the collapse of communist regime following the Round Table talks, the communist successor parties came into power in the fall of 1993. Although there were some concerns about their performance in power, the Pawlak (199395), Oleksy (1995-96), and Cimoszewicz (1996-97) governments did not deviate from the path of political and economic reforms launched in the previous Solidarity governments. In addition, they continued to work for joining the EU and the NATO. Walesa's loss against the former communist, A. Kwasniewski in the 1995 presidential elections, Kwasniewski's re-election in 2000, and the 2001 parliamentary elections reinforced the position of the post-Communist left in the country. In addition, Poland's 
first post-communist constitution was enacted when the former communists dominated both the legislative and executive offices. Nevertheless, the return of former communist elite did not hinder the democratic consolidation; rather, it facilitated it to a great extent as they followed a moderate and pragmatic path. The SLD/ SdRP, the major communist successor party, rapidly adapted itself to the European-style social democratic parties (Lewis and Millard 2001: 186-7, Castle and Taras 2002: 118-29, Curry 2003: 20, Vachudova 2008: 868).

From the left to the right, the Polish political scene includes the communist successor (SLD, UP), the centrist, liberal-democratic (UD, UW, PO), the postSolidarity/centre-right (Solidarity, BBWR, PC, ChDSP, AWS), and the Catholic nationalist (ZcHN, ROP, LPR, PiS) parties. In addition, populist (Samoobrana) and minority/regional (German Minority and Movement for Autonomy of Silesia) parties succeeded in retaining seats in the parliament. Two major cleavages shaped party politics: (i) state interventionist/welfare state versus liberal economic policies, and (ii) the secular versus Catholic social divide (Wesolowski 1996: 244, Lewis and Millard 2001: 186-90, Szczerbiak 2006: 100-4) ${ }^{124}$. Reflecting high level of public commitment to democratic regime and wide elite consensus on major political, economic, and foreign policy issues, the post-Communist Polish democracy has never involved an anti-system party. No doubt, the rapid evolution of communist successor parties in line with social democratic parties in Europe played an important role for the lack of anti-system parties in the country.

\footnotetext{
${ }^{124}$ Interview with Maciej Duszczyk
} 
The cause of European integration and the EU accession process found strong support among the Polish political parties. Membership to the EU was an important element of the cross-party consensus in the aftermath of the 1989 changes. Both the 1993-97/2001-04 left and the 1997-2001 right governments took clear positions in favor of EU membership. On the eve of the 2001 elections, four major parties in parliament (AWS, UW, SLD, and PO), either governing or the opposition, signed a pact in favor European integration on August 22 (Yearbook of Polish European Studies 2001: 205-6). Before the EU referendum of June 7-8, 2003 (77.5 percent of Poles voted for YES ${ }^{125}$ ), the SLD, UP and PO vigorously pursued pro-EU campaigns while the PSL and PiS also followed a pro-EU position. Among Poland's weak Euro-skeptic parties, only the LPR pursued a NO campaign (Szczerbiak 2004: 265-6). ${ }^{126}$ Furthermore, the EU accession process, particularly the 1993 Copenhagen political and economic criteria, played reinforcing and accelerating roles for the post-1989 reforms in the country. ${ }^{127}$ Finally, the accession process helped the transformation of the communist successor parties in line

125 "Poles says big Yes to EU”, BBC News, June 9, 2003 (http://news.bbc.co.uk/2/hi/europe/2973738.stm)

${ }^{126}$ An overwhelming majority of interviewees in the author's field study confirmed the cross-party consensus on the EU membership and the weakness of Euro-skeptical parties. When asked for comparing the Buzek (AWS, 1997-2000, 2000-01) and the Miller (SLD, 2001-2003, 2003-4) coalition governments in regard to the EU accession process, some interviewees noted that the Catholic-nationalist members of the Buzek governments posed a challenge but they were not able to change the pro-EU position of the governments (Interviews with M. Ostrowski, F. Golembski, K. Bobinski, and L. Jesien).

${ }^{127}$ Poland's National Strategy for Integration (1997) was a key step to prepare the country for the accession negotiations. The document underlined that the cause of European integration was a strategic objective for all Polish governments since 1989 as it was aspired by the majority of Polish society. In addition, it stated that post-1989 Polish governments and Poles considered the integration critically important for the stability of democracy and modernization of the economy and the legal system. Hence, the EU membership was deemed as an integral part of the political and economic transformation of the post-Communist Poland. "National Strategy for Integration: The Committee for European Integration" in Yearbook of Polish European Studies, Volume 1, 1997, pages: 180-233. When the accession negotiations were launched on March 31, 1998, the Polish government stated as follow: “...the EU membership of our country, in combination with membership in NATO, will be conducive to the consolidation of the democratic order and security in this part of the continent". "Statement on Opening of Poland's Negotiation on Membership in the EU" in Yearbook of Polish European Studies, Volume 2, 1998, pages: 295-304. 
with European social democratic parties. Their technocratic expertise gave them an important advantage over the post-Solidarity parties to handle the accession related reforms (Vachudova 2008: 868-9).

\section{Stateness}

As one of the most ethnically homogeneous country in the world, Poland has been free from any problem concerning stateness. Therefore, it has never posed a challenge for the consolidation of post-Communist Polish democracy. According to the 2002 nationwide census, there are nine national (Germans, Ukrainians, Belorussians, Lithuanians, Slovaks, Russians, Jews, Armenians and Checks) and four ethnic (Roms, Tartars, Lemkos, and Karaites) minorities in the country. The most populous minorities are Germans (0.40\%), Belorussians (0.12\%), Ukrainians (0.07\%), and Roma people $(0.03 \%)^{128}$

Although the ethnic composition of the population makes any claim for ethnic separatism unlikely, domestic and European dynamics also have helped Poland remain aloof from the stateness problem.

First of all, Poland's tiny size of minorities is not concentrated across the country except Opole region's German minorities, which are also strongly integrated with Poles. In Opole region, the German minorities make fifty percent of the population in thirty-four communes and eight towns. The relatively easy access for ethnic and national minorities to local governments also facilitates their successful integration to the Polish society

\footnotetext{
128 The Polish Ministry of Interior and Administrator, "Characteristics of ethnic and national minorities in Poland"- http://www2.mswia.gov.pl/portal.php?serwis=en\&dzial=10\&id=56
} 
(Okraszewska and Kwiatkowski 2002: 192, Zaucha 1999: 69-70, Vermeersch 2009: 177).

Second, the lack of constitutional guarantees for the protection of minority rights until 1997 was compensated to some extent through the rulings of the Constitutional Court and Poland's commitment to the European Court of Human Rights in line with her membership in the Council of Europe. Later, the April 1997 constitution has provided constitutional guarantees for national or ethnic minorities to maintain and develop their own language, customs, traditions, culture as well as to establish educational and cultural institutions (Article 35). In addition, the constitution's inclusion of rules on local selfgovernment (Chapter 7) has made the enjoyment of rights of the ethnic and national minorities easier (Kerlin 2005: 3-21).

Moreover, Poland's electoral system facilitated representation of minority/regional parties in the parliament. While the 1993 electoral law put electoral threshold for individual parties (5\%) and electoral coalition (8\%), minority/regional parties have been exempted from any electoral threshold. For example, the German minority party succeeded to have seats in the parliament in all parliamentary elections from 1991 to 2001 (7 seats in 1991, 4 seats in 1993, 2 seats in 1997, and 2 seats in 2001). Finally, Poland's first and second round of local government reforms (in early and late 1990s) worked favorably for the country's ethnic and national minorities, particularly for the Opole region's German minorities (Kerlin 2005: 3-21, Ferry 2003: 1104). An important dynamic behind the local government reforms was that Solidarity governments worked more vigorously than the former communists (Kowalczyk 2000: 222, Ferry 2003: 1107). 
The EU accession process reinforced and expanded the rights and opportunities for Poland's tiny ethnic minorities in three major ways: (i) monitoring on minority rights through the annual progress reports, (ii) requiring the ratification of European conventions on minority rights as a part of the EU acquis, and (iii) asking Poland's alignment with the EU's regional policy, particularly by allocating funds for local governments (Kirchner 1999: 209-10, Zaucha 1999: 76-78, Swianiewicz and Herbst 2002: 231). Particularly notable, Poland's second round of local government reforms (1998) converged with the EU accession process. The EU's requirement for Poland's alignment with EU's regional classifications (NUTS) accelerated the drive for decentralization in the country. The EU all annual progress reports (1998 to 2003) noted that Poland fulfilled the Copenhagen political criteria, which also involves the protection of minorities. In addition, the 1998 report suggested that Poland's local government reform (1998) will enhance the representativeness of Opole region's German minorities.

Overall, post-communist Polish democracy did not involve any problem concerning stateness. Poland's favorable domestic dynamics were most helpful for the country's tiny size of ethnic and national minorities. The EU accession process helped the protection of minority rights, and accelerated Poland's second round of decentralization reforms.

Table 4.4 summarizes the domestic and European dynamics of democratic consolidation by each of the four components. 
Table 4.4: European versus Domestic Dynamics of the Consolidation

\begin{tabular}{|c|c|c|c|}
\hline $\begin{array}{l}\text { Components } \\
\text { of Democratic } \\
\text { Consolidation }\end{array}$ & $\begin{array}{l}\text { Major Events- } \\
\text { Key Developments }\end{array}$ & Domestic Dynamics & European Dynamics \\
\hline $\begin{array}{l}\text { 1. Free, fair, } \\
\text { and } \\
\text { competitive } \\
\text { elections }\end{array}$ & $\begin{array}{l}\text {-The Round Table Talks } \\
\text { (Feb-April 1989) } \\
\text {-Semi-competitive } \\
\text { parliamentary elections } \\
\text { (June 1989) } \\
\text {-First fully competitive } \\
\text { parliamentary elections } \\
\text { (October 1991) }\end{array}$ & $\begin{array}{l}\text {-Peaceful transfer of power } \\
\text { between the Solidarity and the } \\
\text { communist successor parties } \\
\text {-Holding parliamentary, } \\
\text { presidential, and local } \\
\text { elections without any } \\
\text { considerable problem }\end{array}$ & $\begin{array}{l}\text {-Poland-EU } \\
\text { Association } \\
\text { Agreement (1991) set } \\
\text { holding democratic } \\
\text { elections as a } \\
\text { condition } \\
\text {-The EU's democratic } \\
\text { conditionality (the } \\
\text { Copenhagen political } \\
\text { criteria) anchored the } \\
\text { maintenance of } \\
\text { democratic elections }\end{array}$ \\
\hline $\begin{array}{l}\text { 2. The } \\
\text { protection of } \\
\text { basic rights } \\
\text { and liberties, } \\
\text { human and } \\
\text { minority } \\
\text { rights }\end{array}$ & $\begin{array}{l}\text {-1989-90 constitutional } \\
\text { amendments } \\
\text {-April } 1997 \text { constitution }\end{array}$ & $\begin{array}{l}\text { - The rulings of Polish } \\
\text { Constitutional Tribunal in } \\
\text { favor of European human } \\
\text { rights conventions } \\
\text { The Office of Civil Rights } \\
\text { Ombudsman }\end{array}$ & $\begin{array}{l}\text {-The Council of } \\
\text { Europe membership } \\
\text { and adoption of the } \\
\text { ECHR (1991) } \\
\text {-The EU set the } \\
\text { ratification of } \\
\text { international } \\
\text { covenants on human } \\
\text { and minority rights as } \\
\text { a part of the EU acquis } \\
\text { - Death penalty } \\
\text { abolished (April 2000) } \\
\text { to align with the EU } \\
\text { acquis } \\
\text { - The Commission } \\
\text { reports (1998-2003) } \\
\text { monitored } \\
\text { developments in this } \\
\text { area. } \\
\text { - EU's help to human } \\
\text { rights NGOs and } \\
\text { minorities }\end{array}$ \\
\hline
\end{tabular}




\begin{tabular}{|c|c|c|c|}
\hline $\begin{array}{l}\text { 3. High } \\
\text { prospects of } \\
\text { regime } \\
\text { survival and } \\
\text { civilian } \\
\text { control of the } \\
\text { military }\end{array}$ & $\begin{array}{l}\text { - 1989-90 military reforms } \\
\text { - First civilian defense } \\
\text { minister appointed } \\
\text { (December 1991) } \\
\text { - Poland's withdrawal from } \\
\text { the Warsaw Pact (July } \\
\text { 1991) } \\
\text {-The withdrawal of Soviet } \\
\text { military troops (1991-93) } \\
\text { - The Parys affair (Spring } \\
\text { 1992) } \\
\text { The Drowsko affair (Fall } \\
\text { 1994) }\end{array}$ & $\begin{array}{l}\text { - The legislative-executive } \\
\text { clash over control of the } \\
\text { military (1992-1995) } \\
\text { - Memberships in the NATO } \\
\text { and the EU were officially set } \\
\text { as 'strategic goals' (November } \\
\text { 1992) } \\
\text { - Ratification of the Ministry } \\
\text { of Defense Act by A. } \\
\text { Kwasniewski (December } \\
\text { 1995) } \\
\text { - April 1997 constitution } \\
\text { confirms the subordination of } \\
\text { the General Staff to the } \\
\text { civilian defense minister. }\end{array}$ & $\begin{array}{l}\text {-Poland's participation } \\
\text { in NATO's PfP since } \\
1994 \text { helped military } \\
\text { reforms } \\
\text {-NATO set the civilian } \\
\text { control of the army as } \\
\text { a condition for the } \\
\text { membership; NATO } \\
\text { accession process } \\
\text { (1994-99) accelerated } \\
\text { efforts for the civilian } \\
\text { control } \\
\text {-NATO membership } \\
\text { (1999) anchored } \\
\text { maintenance of the } \\
\text { civilian control } \\
\text {-EU accession process } \\
\text { did not have any direct } \\
\text { impact but it } \\
\text { safeguarded the } \\
\text { civilian control of the } \\
\text { army }\end{array}$ \\
\hline $\begin{array}{l}4.1 \\
\text { Legitimacy }\end{array}$ & $\begin{array}{l}\text {-Parliamentary (1991,'93, } \\
\text { '97, 2001) and Presidential } \\
(1995,2000) \text { Elections } \\
\text {-Constitutional } \\
\text { Referendum (May 1997) }\end{array}$ & $\begin{array}{l}\text {-Polls showed that Poles had a } \\
\text { high level of commitment to } \\
\text { democratic regime although } \\
\text { there was unease about the } \\
\text { performance of post- } \\
\text { Communist governments, } \\
\text { particularly until the mid- } \\
\text { 1990s. }\end{array}$ & $\begin{array}{l}\text {-European integration; } \\
\text { reinforcing and } \\
\text { symbolic role for the } \\
\text { post-Communist } \\
\text { democracy } \\
\text { - The EU accession } \\
\text { process made indirect } \\
\text { contributions through } \\
\text { modernizing } \\
\text { infrastructure/public } \\
\text { administration and } \\
\text { requiring fight against } \\
\text { corruption } \\
\text {-High mass and elite } \\
\text { support for the EU } \\
\text { membership }\end{array}$ \\
\hline
\end{tabular}




\begin{tabular}{|c|c|c|c|}
\hline $\begin{array}{l}4.2 \text { Anti- } \\
\text { System } \\
\text { Parties }\end{array}$ & - No anti-system party & $\begin{array}{l}\text {-High level of elite consensus } \\
\text { on democratic reforms, } \\
\text { market transition, and Western } \\
\text { foreign policy orientation } \\
\text {-The SLD/SdRP; the major } \\
\text { communist successor parties } \\
\text { followed pragmatic and } \\
\text { moderate line; they rapidly } \\
\text { adapted into European social } \\
\text { democracy }\end{array}$ & $\begin{array}{l}\text {-The cause of } \\
\text { European integration } \\
\text { was a key part of the } \\
\text { elite consensus } \\
\text {-The SLD and the UP } \\
\text { became members of } \\
\text { the Socialist } \\
\text { International (1996) } \\
\text {-The UW joined the } \\
\text { Christian Democratic } \\
\text { International (1996) }\end{array}$ \\
\hline 4.3 Stateness & $\begin{array}{l}\text {-Poland is one of the most } \\
\text { ethnically homogenous } \\
\text { country in the world } \\
\text {-The lack of any separatist } \\
\text { group or party. } \\
\text {-The lack of Soviet } \\
\text { dominance was critical for } \\
\text { sovereignty of the post- } \\
\text { Communist Polish } \\
\text { democracy }\end{array}$ & $\begin{array}{l}\text {-Local government reforms in } \\
\text { the early 1990s. } \\
\text {-1997 constitution provides } \\
\text { guarantees for minority rights }\end{array}$ & $\begin{array}{l}\text {-The Council of } \\
\text { Europe/ECHR help in } \\
\text { regard to minority } \\
\text { rights } \\
\text {-The EU's } \\
\text { conditionality required } \\
\text { adoption of } \\
\text { international } \\
\text { conventions on } \\
\text { minority rights as a } \\
\text { part of the acquis. }\end{array}$ \\
\hline
\end{tabular}

\section{Conclusion}

The European integration process and the EU's democratic conditionality contributed to democratic consolidation of post-Communist Poland in several ways. In this chapter, the EU's democratizing effects have been examined in line with the fourpart definition of consolidation. Since the fully competitive parliamentary elections in October 1991, the Polish democracy has successfully maintained the first component of the consolidation. Neither a risk of democratic breakdown and/or authoritarian retreat nor ethnic separatism has posed a challenge for the consolidation process. Particularly 
important, broad consensus between Solidarity and the post-Communist elite on the political and economic reforms facilitated the course of democratic consolidation.

Although European actors did not play a decisive role for the democratic transition as compared to the non-interventionist policy of the Soviet Union, they were quite helpful during the consolidation period. The Council of Europe membership and the adoption of the European Convention of Human Rights helped to improve human rights standards in the country. The NATO membership process (1994-99), particularly NATO's conditionality for the democratic control of the armed forces, accelerated the reforms concerning the civil-military relations. Later, Poland's accession to NATO provided a significant anchor role to uphold democratic control. Finally, the European integration process generated most comprehensive democratizing effects for the consolidation of Polish democracy. The integration process set a favorable international context for the acceleration of post-1989 political and economic reforms. As discussed above, the EU accession process through the democratic conditionality clause made various contributions to the four components of the consolidation. To a great extent, Europeanization and democratization turned out to be convergent and parallel processes for post-Communist Poland. In an important symbolic way, Poland's accession to the EU in May 2004 confirmed that the consolidation process reached an unprecedented level of progress. Nevertheless, the European integration process and the EU's democratic conditionality also involved several limitations.

First of all, the EU did not develop a clear conception of democratic consolidation for the CEE candidate countries including Poland. The Copenhagen political criteria required 'stability of institutions guaranteeing democracy, the rule of law, human rights, 
and respect for protecting of minorities'; however, the EU lacked clear definitions for democracy and democratic consolidation. This ambiguity posed an important limitation for the EU's impact on democratic consolidation (Andrezejewicz 2004: 289, Pridham 2006: 381, Grabbe 2007: 117). Second, the period of accession negotiations (1998-2002) was driven by the EU's focus on harmonization of the Polish legislation with the EU acquis. Although the legislative alignment and the acquis related reforms (public administration, judiciary, and fighting against corruption i.e.) were indirectly related to consolidation, the technical nature of the accession negotiations also limited the EU's leverage for the democratic consolidation. Third, the top-down, elite-centered nature of the accession negotiations paved the way for excessive bureaucratization. Besides, Europeanization or EUization of the Polish legislation during the accession negotiations enhanced the political power of the executive vis-à-vis parliament and local governments (Pridham 2002: 955). As a result, the accession process also involved some negative effects for participatory democracy. Several interviewees in the author's field study shared their concerns in line with these negative aspects of the EU accession process. ${ }^{129}$

What factors were conditioned the EU's democratizing impact in Poland's accession process? In this regard, two dynamics played the most important roles: (i) the EU's credible commitment to the prospect of Poland's membership if the Copenhagen conditions were fulfilled, and (2) cross-party consensus and high level of public support for accession to the EU. In other words, the EU's contributions to various aspects of the democratic consolidation occurred when these two elements were present (Pridham 2002: 963, Grabbe 2007: 120-1).

${ }^{129}$ Interviews with F. Golembski, K. Bachmann, D.Karwoth, and P.Poncyljusz. 
Moreover, the EU's help to post-Communist Polish democracy involved two notable variations. First, the EU's democratizing impact was at low profile before the June 1993 Copenhagen European Council meeting in which the CEE countries including Poland were provided a clear prospect of full-membership. Thereafter, the EU did have an increasing level of leverage on domestic political changes in relation to democratic consolidation. Particularly, the period of accession negotiations (1998-2002) involved the highest level of EU monitoring and harmonization of the Polish legislation. Second, the EU's democratizing effects were more successful at the level of institutional/legislative changes vis-a-vis societal changes and the implementation of those legislative changes (Pridham 2006: 395-8).

Keeping all these limitations and variations in mind, the European integration process was a significant international dynamic for the consolidation of Polish democracy. This process accelerated the country's systemic transformation after 1989 towards an European style liberal democracy and a market economy. In addition, it helped overcome the authoritarian legacy of the Communist era. The EU accession in May 2004 was to a great extent a confirmation of the Polish success story. Moreover, the EU's democratic conditionality anchored the Polish democracy in regard to human and minority rights as well as the civilian control of the armed forces. Although the Council of Europe and NATO also played important roles in these areas, the EU's anchor role for the candidate and the member countries should not be overlooked. Finally, the EU acquis related reforms in the areas of public administration, the judiciary, and the fight against corruption enhanced the quality of Polish democracy, and made indirect contributions to the consolidation process. 


\section{CHAPTER V}

\section{EUROPEAN INTEGRATION AND DEMOCRATIC CONSOLIDATION: THE CASE OF TURKEY}

Having a secular state (since 1923), multi-party democracy (since 1950) and a predominantly Muslim population, Turkey is a unique example in world politics. The ongoing accession negotiations with the European Union are a culmination of the country's two century long process of Westernization. Nevertheless, Turkey has not yet consolidated democracy, as defined by the four components in this dissertation. As seen through the $1960,1971,1980$, and 1997 interventions, the military has frequently taken part in politics, and maintained extensive prerogatives in the constitutional system. The 1982 constitution (adopted after the 1980 military coup) has put extensive restrictions on fundamental rights and liberties while prioritizing order, security, and the state over liberties, society and individual. Moreover, the 1984-1999 armed conflict with the separatist Kurdish organization (PKK) in particular and the Kurdish question in general are other major challenges for the consolidation of democracy in the country. The strict secularist and nationalist policies followed since the foundation of the Republic have failed to overcome the Islamist and Kurdish opposition. Ideational transformation of the political Islamists in the aftermath of the 1997 military intervention has made significant contribution to the democratic consolidation, while the Kurdish question still remains a major challenge. Furthermore, the accession process with the European Union (1999-

present) has generated an unprecedented level of political reforms, which are central for making progress on various dimensions of democratic consolidation. 
The EU accession related political reforms were most decisive in the period of 2001-2004 when Turkey realized impressive legislative and constitutional changes to fulfill the prerequisite of launching accession negotiations-, the Copenhagen political criteria. The most notable reforms in this period were mainly related to the second and third component of democratic consolidation: protection of fundamental rights and liberties including human and minority rights, and democratic control of the armed forces. The 2001-04 period involved a 'silent revolution' in the country's history, according to both domestic and international observers of Turkish politics. Later, the momentum for reforms noticeably faded with the declining prospect of EU membership. The partial suspension of the accession negotiations and the deadlock in the Turkey-EU relations lessened the EU's leverage over democratization and human rights reforms in the country.

This chapter will first briefly examine the key dynamics behind Turkey's transition to a multi-party democracy (1946-1950) in the context of the late Ottoman and the early Republican periods. Then, it will assess the consolidation process of Turkish democracy in line with the four components. In doing so, this section will also analyze the extent to which the EU accession process has contributed to realizing progress on each component.

\section{Earlier is Not Always Better: Turkey's Transition to Democracy (1946-50)}

Compared to the democratic transitions in Spain (1975-77) and Poland (1989-91), Turkey's transition to democracy occurred earlier with the holding of free, fair and competitive elections first time in May 1950. The establishment of the Democratic Party 
(Demokrat Parti, DP) and its participation in the July 1946 elections could be set as the beginning of the transition process. ${ }^{130}$ In the historic 1950 elections, the DP ended the Republican People's Party's (Cumhuriyet Halk Partisi, CHP) twenty-seven year long one-party rule, and the country experienced transition to a multi-party democracy ${ }^{131} \mathrm{~A}$ brief historical background of the late Ottoman and the early Republican periods could be essential to understand the timing and dynamics of Turkey's democratic transition.

In response to numerous signs of decline, the Ottoman rulers launched modernization reforms first in the military realm beginning in the late $18^{\text {th }}$ century. In the early to mid-1850s, the reform efforts expanded into the legal and administrative spheres. The 1839 Tanzimat ('Reorganization') and the 1856 Islahat ('Reform') Edicts enhanced the state's commitment to the rule of law, paved the way for a new (more secular) penal code, and expanded the rights of non-Muslim people. The Tanzimat Period (1839-76) also witnessed the establishment of secular educational institutions and the creation of efficient centralized bureaucracy (Findley 1980: 112-50, Ahmad 1993: 15-30, Kia 2008: 115-36). As a result of these changes, the old religious class of scholars ('Ulema') began to lose their leverage while a new class of political and cultural elite gained more influence in the late $19^{\text {th }}$ century. The new elite ('the Young Ottomans'), who were well familiar with secular and Western political ideas, demanded curbing the authority of the

\footnotetext{
${ }^{130}$ The 1946 elections did not meet the fairness criteria of the democratic elections as they were held under the supervision of the governing Republican People's Party (CHP) instead of a partial electoral authority. Open voting and secret counting in the elections were also other major deficiencies in regard to the fairness. The CHP did have 85 percent of the votes (395 MPs) while the Democratic Party (DP) acquired the 13 percent (66 MPs).

${ }^{131}$ In the 1950 elections, the DP succeeded to beat the CHP with 53\% of the votes (408 MPs) while the CHP was able to have only 69 seats in the parliament with 40 percent of the votes. (Sayari and Esmer 2002: 189-90).
} 
Ottoman Sultan in order to establish a regime of constitutional monarchy (Shaw and Shaw 1977: 18-33). In 1876, the Sultan Abdulhamit II declared the constitution ('Kanun-i Esasi') and accepted the creation of a parliament.

The First Constitutional era was short-lived as the Sultan dissolved the parliament one year later, justifying his decision with the outbreak of a war with Russia (1877-78). The restoration of the Constitutional Monarchy became possible only about thirty-years later (1908) as a result of a coup ran by the Committee of Union and Progress (Ittihat ve Terakki, CUP). The CUP, which was composed of military and civilian members (including the founder of the Turkish Republic, Mustafa Kemal Ataturk) encompassed diverse groups (Ottomanists, Turkish nationalists, Westernists, Islamists i.e.) with an overarching goal of restoring the Constitutional Monarchy. The Second Constitutional Monarchy era (1908-18) under the CUP rule witnessed multi-party elections (1908 and 1912) even though they were held with widespread fraud and no female suffrage (Kayali 1995: 273-82). The CUP criticized Sultan Abdulhamit II for his autocratic rule; ironically, the CUP followed a highly authoritarian and (Turkish) nationalist pattern of politics under its rule (Karpat 1959: 3-31, Dodd 1965: 3-19, Ahmad 1993: 31-51). Nevertheless, the 1908-18 period is an important era to understand the extent to which the foundation of the Republic (1923) represented change and continuity in the country's political history.

Following the dissolution of the Ottoman Empire after the First World War, the War of Independence paved the way for the foundation of the Turkish Republic under the leadership of a charismatic leader, Mustafa Kemal Ataturk. He ruled the country until his death in 1938. The Ataturk era witnessed radical changes in the political and cultural 
landscape: abolition of the Ottoman dynasty (1922) and the Caliphate (1924), the proclamation of the Republic (1923), enactment of a new constitution (1924), introduction of new penal (Italian) and civil (Swiss) codes (1926), adoption of the Latin alphabet (1928), the introduction of full political rights to women (1934), and inclusion of the principle of secularism in the constitution (1937) (Dodd 1969: 20-51, Karpat 1959: 32-76). To some extent, Ataturk's reforms were culmination, with acceleration, of the late Ottoman period of changes in favor of secularization, Europeanization/Westernization, and Turkish nationalism. However, these reforms did not generate a multi-party democracy in the country. Following two failed attempts to allow the operation of opposition parties in 1924 and 1930, 'state-dominant monoparty authoritarianism' survived until the May 1950 elections (Sunar and Sayari 1986: 168, Ahmad 2008: 17-19). Despite undertaking radical changes, the Republican period was remarkably similar to the late Ottoman era: state-led, top-down process of modernization under authoritarian rule in which the urban, bureaucratic 'center' dominated over the 'periphery' of rural people and local notables (Mardin 1973: 181-84, Sunar and Sayari 1986: 169-71). In other words, both the late Ottoman and the early Republican periods of state-led modernization occurred without generating major progress in the realm of democratization (Keyman and Onis 2007: 12-15).

A combination of several domestic and external dynamics was responsible for the transition to a multi-party democracy (1946-50). First of all, the death of charismatic founder Kemal Ataturk (1938) made easier the rise of political opposition against the CHP's one-party rule. Moreover, the party's statist economic policies and the practices of strict secularism created a backlash among the liberal economic groups and the 
conservative countryside. In addition, the Capital Levy (1942) and the Land Reform Bill (1945) resulted in discontent among the landowners. As a result, the CHP's social basis (the bureaucracy, the landlords, and the private sector) began to lose its coherence in the early-to-mid 1940s (Karpat 1959: 137-45, Dodd 1965: 23-4, Ahmad 1993: 102-3). Furthermore, the victory of Western powers in the Second World War and Turkey's security orientation in favor of the West/the United States against the Soviet Union played an important role in three areas: (i) divisions in the ruling CHP (the reformists versus the hardliners), (ii) President Ismet Inenu's (former CHP leader) decision to move to a multi-party democracy, and (iii) the Democrat Party's employment of liberal ideas in favor of multi-party democracy. To a great extent, the international context after the War and Turkey's preference to join the US-led Western world shaped the timing of Turkey's transition to democracy (Karpat 1959: 141-43, Shaw and Shaw 1977: 400-404, Huntington 1991: 40, Ahmad 2008: 127-130). Finally, the Westernizing thrust of Ataturk's reforms/the Kemalist ideology required the transition eventually, and this facilitated Inenu's decision for the transition (Sunar and Sayari 1986: 172, Ozbudun 2000: 16-24, Karpat 1959: 138). The transition process did not involve any radical break; rather, it occurred in a reform mode of democratic transition. Instead of pressures from societal groups or classes, the transition to democracy was mostly an outcome of Inenu's decision and the cooperation between the CHP's reformist wing and the moderate DP, which was founded by former CHP members.

The overall nature of the transition as 'democratization from above' later will set the fragility of Turkish democracy as seen in the 1960, 1971, and 1980 military coup d'etats (Sunar and Sayari 1986: 172-74) Although the Turkish military restored 
democracy within a few years after each intervention, the bureaucratic-military center remained dominant vis-à-vis the political parties and the civil society from the inception of the transition to the late 1980 s. ${ }^{132}$ As will be detailed later in this chapter, the coup d'etats gradually enhanced the military tutelage in the political landscape. As a result, the Turkish politics experienced a cyclical pattern alternating between military regimes and populist democratic governments in the period of 1960-1980 (Huntington 1991: 41). In addition to the military's guardianship, the low degree of cooperation among political party leaders and the high level of political violence played crucial roles in the outbreak of the 1980 coup. Nevertheless, the increasing levels of urbanization and political participation in the three decades after the transition (1950-80) paved the way for the rise of civil society and the proliferation of non-state political actors in the post-1980 period (Sunar and Sayari 1986: 174-82, Birtek 1994: 226-7).

The September 12, 1980 military coup and the enactment of the military-led 1982 constitution severely restricted the scope of political life: the military gained further prerogatives in the constitutional system, political parties were dissolved and their leaders were banned from politics until 1987, only three new parties were allowed to take part in the 1983 parliamentary elections, a $10 \%$ national threshold was set for the elections, and the exercise of fundamental rights and liberties faced serious restrictions in the new constitution (Ozbudun 2000: 57-60, Kalaycioglu 2005: 125, Ahmad 2008: 185-89). In addition, General Kenan Evren, who headed the coup, served as the President until

\footnotetext{
${ }^{132}$ Two major reasons can be noted for the fact that the military restored democracy quickly: (i) the Westernizing drive of the Kemalist ideology could not allow long periods of military rule, and (ii) the military's commitment to pro-Western foreign and security policy (NATO membership since 1952 i.e.) made it more responsive to Western criticisms of regime problems (Karaosmanoglu 1994: 126, Ozbudun 2000: 22).
} 
November 1989. Moreover, the coup resulted in worsening of Turkey's relations with the European Community: the EC suspended the relations after the intervention, and rejected Turkey's application for full-membership (1987) in December 1989 on the basis of economic and political concerns (Karaosmanoglu 1994: 129). ${ }^{133}$

In spite of all these negative consequences of the coup, Turkish politics also witnessed some positive developments in the 1980s and 1990s. The highly statist/nationalist Kemalist ideology experienced transformation towards a more liberal interpretation, which made possible the expansion of the civilian-political sphere. The first civilian president since the foundation of the Republic got elected (Turgut Ozal, 1989-1993). The statist economic policies were replaced by market friendly policies. In addition, Turkey's political landscape witnessed the increasing influence of civil society, public opinion and media (Ahmad 1993: 213-17, Heper 1994a: 20; 1994b: 233, Caha 2005: 20-26). As the 1997 military intervention demonstrated, the five-decade old Turkish democracy was still far away from consolidation on the eve of the December 1999 Helsinki European Council meeting, which launched the Turkey-EU accession process.

\section{The Consolidation of Turkish democracy and the EU Accession Process}

The following section will assess the democratizing impact of EU accession process on the consolidation of Turkish democracy in line with the four-part definition of consolidation in this dissertation: (i) free, fair, and competitive elections with universal suffrage, (ii) protection of fundamental rights and liberties as well as human and minority

\footnotetext{
${ }^{133}$ Turkey applied first for the EC membership in July 1959, and the EC responded to the application with the establishment of the Associate Agreement on September 12, 1963.
} 
rights, (iii) high prospects of regime survival and civilian control of the military, and (iv) legitimacy, anti-system parties, and stateness.

\section{Free, fair, competitive elections with universal suffrage; no politically significant group should be excluded from electoral competition.}

Since the transition to multi-party democracy in 1950 , sixteen parliamentary elections have been held up to present time ${ }^{134}$. With the exception of three military interregnums (1960-61, 1971-73, 1980-83), the country has been ruled by democratically elected governments. The first elections following the 1960, 1971, and 1983 military interventions were not fully competitive as the military regimes either banned major political parties or prevented them from participating in the elections. The 1957 elections involved serious problems of vote counting (Sayari 2002b: 179-84, Kalaycioglu 2002: 55-71). In the rest of the elections (12), the free and fair components of democratic elections were fulfilled without any considerable problem. However, the frequent cases of party closures have posed a major challenge for the execution of fully competitive electoral process while the communist, Kurdish and Islamist political parties have been frequently closed in the country. ${ }^{135}$ The Political Parties Law (1983) prohibits the use of 'Communist' for a title of a political party. In 1993, the Constitutional Court closed the Socialist Party of Turkey (STP) on the basis of a ruling that the party demanded establishing a federal state structure in the country (Ozbudun 2002: 20-22). In addition, several Islamist parties were dissolved due to their alleged 'anti-secular activities',

\footnotetext{
${ }^{134}$ For the list of the elections, see Table 5.1

${ }^{135}$ Since the establishment of the Turkish Republic, fifty-seven political parties were closed; 19 in 1924-80, 17 in 1981, and 21 in 1983-2009 (Coskun 2008: 147-48, Kaptikacti et al 2008: 36-39).
} 
despite the fact that their activities were free from violence (core criteria of the Council of Europe's Venice Commission in regard to party closures).

The bans on political parties and their presidents by the September 1980-83 military regime were eliminated with the 1987 constitutional referendum. Later, the 1995 constitutional amendment removed serious restrictions concerning the organization of political parties; the opening of youth and woman branches was allowed in addition to the legalization of links with labor unions and associations. In the past decade, the 2001 constitutional amendment and two EU harmonization law packages (2002-2003) made it difficult to dissolve political parties. This was done in three major ways: (i) by asking far high level substantive evidence to initiate the closure investigation, (ii) by bringing in alternative penalties (depriving of state funding i.e,) in addition to closure, and (iii) by requiring a $3 / 5$ majority instead of a simple majority for a closure decision by the Constitutional Court ${ }^{136}$ (Ozbudun and Genckaya 2009: 58, The EU Harmonization Law Packages 2007: 6-13).

Despite these positive changes, further reforms in this realm are necessary as suggested by the European Union and the Venice Commission. The recent cases of party closure including the governing JDP (2008, not closed) and the Kurdish DTP (2009, closed) have shown that these practices diverge from the European standards. The latter allow rare cases of party closure in line with the wide range of freedoms of expression and association. ${ }^{137}$ Several rulings by the European Court of Human Rights concerning

\footnotetext{
${ }^{136}$ A practical consequence of this change was visible in the closure case of the governing JDP. Six judges in the 11-member Constitutional Court voted for dissolving the party, falling only one vote short of the necessary majority of 7 . As a result, the $3 / 5$ majority rule saved the governing party from the closure.

${ }^{137}$ An opinion by the Council of Europe's Venice Commission ('European Commission for Democracy through Law') found three major differences between Turkey and 'the common European practice' as
} 
the closure of political parties concluded that Turkey violated the $10^{\text {th }}$ (freedom of expression) and $11^{\text {th }}$ (freedom of association) articles of the ECHR (Yazici 2009: 19-59). The ECtHR rulings also show that fully competitive elections could only be possible if they are supported by the second component of consolidation: the protection of fundamental rights and liberties.

Another major issue for Turkish democracy related to competitive elections is that the 10 percent national threshold (since 1983) in the elections is too high and this works against the representation of major political groups in the parliament. Particularly notable, the pro-Kurdish political party failed to take in the parliament in the 1995, 1999, and 2002 elections while they received 4, 4.75, and 6 percent of the votes respectively. In this regard, the EU progress reports have pointed out that the $10 \%$ threshold limits representativeness in parliament but did not consider its correction as a requirement for fulfillment of the Copenhagen political criteria. ${ }^{138}$ An ECtHR ruling on this issue (2007) concluded that the 10 percent threshold does not violate the ECHR as it is up to the countries to decide on the level of the threshold (Yazici 2009: 69).

In regard to the fulfillment of the free, fair, and competitive elections criterion, the European integration process (1999-present) has been most helpful for introducing the 2001-2003 legal changes which made the prohibition of political parties more difficult.

regards the prohibition of political parties. In Turkey, (i) there is a long list of substantive criteria for political parties to conform with the constitution, (ii) to initiate closing political parties is more arbitrary and less subject to democratic control (Chief Public Prosecutor initiates the process), and (iii) dissolving political parties occurs frequently as it is not regarded as 'an extraordinary measure, but as a structural and operative part of the constitution'. Opinion on the Constitutional and Legal Provisions Relevant to the Prohibition of Political Parties in Turkey. Adopted by the Venice Commission at its $78^{\text {th }}$ Plenary Session, Venice, 13-14 March 2009, 24 pages (It is available online at: http://www.venice.coe.int/docs/2009/CDL$\underline{\mathrm{AD}(2009) 006-\text {-e.pdf)}}$.

${ }^{138}$ For example, see the 1999 and 2006 EU Regular Reports on Turkey. 
The EU's regular reports on Turkey have not recorded any considerable problem concerning the 1999, 2002, and 2007 parliamentary elections. ${ }^{139}$ The 2009 and $2010 \mathrm{EU}$ reports asked Turkey to align further its legislation on the closure of political parties with the Venice Commission standards. The governing JDP attempted to make dissolving political parties more difficult through a constitutional amendment. However, the proposed article did not receive enough support in the parliament, and did not take place in the 2010 constitutional referendum. The article intended to make initiating a closure case subject to parliamentary control, in line with the recommendation of the Venice Commission. Currently, the Chief Public Prosecutor does have the sole authority to initiate the closure process.

During the author's field study in Turkey, none of the interviewees found any considerable problem as regards the free and fair character of the democratic elections. ${ }^{140}$ Yet, the competitiveness aspect of the elections received a few numbers of criticisms. Mustafa Kaya, who is a party official from the Felicity Party (pro-Islamic/conservative), suggested that the closure of political parties is one of the major problems of Turkish democracy. Professor Senem Aydin from Bilgi University considered the 10\% electoral threshold an important democracy problem. Moreover, several interviewees contended

\footnotetext{
${ }^{139}$ The OSCE's Office for Democratic Institutions and Human Rights (ODIHR) too confirmed that Turkey's parliamentary elections in 2002 and 2007 were free and fair. OSCE/ODIHR's Election Assessment Mission Reports. The reports are available online at: http://www.osce.org/odihr/elections/turkey/16346 (2002), and http://www.osce.org/odihr/elections/turkey/29181 (2007). The reports found that the elections were satisfactory in term of the free and fairness criteria but also identified three problems concerning the competitiveness quality of the elections: (i) the $10 \%$ electoral threshold is very high, (ii) the Political Parties Law has certain restrictions in regard to the prohibition and organization of political parties, and (iii) the use of Kurdish language in the election campaigns faces severe restrictions.

${ }^{140}$ For the list of interviewees, their affiliations, and the dates of interviews, see Appendix 4. The author used same set of interview questions as those in Spain and Poland (Appendix 1).
} 
that Turkey's Political Parties Law involves a wide range of restrictions, and needs a major democratic overhaul. ${ }^{141}$

\section{Protection of fundamental rights and liberties including human and minority rights}

In contrast to the first component of democratic consolidation, Turkish democracy has experienced severe challenges in this realm despite the fact the transition from oneparty rule to multi-party democratic system took place in 1950. Except the three periods of military rule (1960-61, 1971-73, and 1980-83), Turkey has maintained free, fair, and competitive elections. However, neither fundamental rights and liberties nor human and minority rights reached the levels that consolidated democracies uphold. ${ }^{142}$ In the recent past, the 1980-83 military regime created a constitutional order that put extensive restrictions over fundamental rights and freedoms. The state-centric and nationalist nature of the 1982 constitution has also hindered the provision of necessary protections for human and minority rights. Moreover, the armed conflict with the Kurdish separatist PKK (1984-99), which caused the death of more than thirty-thousand people in the South-East Turkey, resulted in serious violations of human rights.

Despite the gloomy picture of the 1980s and 1990s, Turkish democracy has achieved unprecedented level of progress in the past decade in the realm of the second component of democratic consolidation. In doing so, the EU accession process, particularly the EU's democratic conditionality principle has played a significant role.

\footnotetext{
${ }^{141}$ Interviews with Ziya Muezzinoglu, Yilmaz Ensaroglu, Senem Aydin, Seyfi Tashan, Huseyin Pazarci, Ali Resul Usul, and anonymous law professor from Yeditepe University.

${ }^{142}$ Turkish democracy has never been identified as "Free" in the Freedom House's Civil Liberties and Political Rights Index, which has been maintained since 1973.
} 
The EU's democratizing impact was most visible for the period of 2001-2004 when Turkey vigorously worked for fulfilling the Copenhagen political criteria, required for launching the accession negotiations. In the following period (2005-present), the declining prospect of Turkey's EU membership limited the EU's democratizing impact to a great extent.

The following section will examine the role of the EU accession process for the second component of democratic consolidation. In this regard, the EU's contribution will be assessed for the periods before and after the Helsinki European Council meeting (December 1999), in which the European Union set Turkey as a candidate country for the EU membership.

In the pre-1999 period, the EU did have a very limited impact on Turkey in regard to democracy and human rights. In 1989, the EU rejected Turkey's application for fullmembership (1987) by citing both economic and political reasons. In the early-to-mid 1990s, the EU, especially the European Parliament, frequently criticized Turkey for the increasing amount of human rights violations in the country. The armed conflict with the PKK played a major role in this regard. However, the EU's criticisms did not help much improving Turkey's human rights practices as any prospect of EU membership was lacking. In the pre-Helsinki period, the most notable democratizing impact occurred on the eve of signing the Customs Union agreement with the EU (entered into force in January 1996). At that time, Turkey made some changes in the Anti-Terror Law, the Code on Criminal Law, and the Association Law to expand the freedom of expression. These changes were to a great extent response to the EU's criticisms, as confirmed by then Turkish Prime Minister (Usul 2011: 96). 
One of the most important European contributions to human rights in Turkey in the pre-1999 period was made through the European Convention of Human Rights (ECHR). Turkey ratified the ECHR in 1954 as a member of the Council of Europe (1949); however, it accepted the jurisdiction of the European Court of Human Rights (ECtHR) only in 1990. In addition, Turkey allowed its citizens to make individual application to the ECtHR in 1987 (Turkmen 2007: 254-7, Smith 2007: 262-3). Turkey's acceptance of the ECtHR rulings helped to a great extent for increasing the salience of human rights issues in the country. Yet, the Court's convictions of Turkey's human rights violations were far from making substantial changes in the country's human rights performance.

The Helsinki European Council of December 1999 set a major turning point in the history of Turkey-EU relations. As stated in the conclusion of the Council meeting, Turkey became a "candidate State destined to join the Union on the basis of the same criteria as applied to the other candidate States". ${ }^{143}$ Like other candidate countries, Turkey's membership was set conditional upon compliance with the Copenhagen criteria. ${ }^{144}$ Particularly, the Council set fulfillment of the political criteria as a prerequisite for the opening of accession negotiations. Thereafter, the EU built a preaccession strategy for Turkey on the basis of three major components: (i) the Accession

\footnotetext{
${ }^{143}$ The Helsinki European Council, 10-11 December 1999, Presidency Conclusions, paragraph 12. (It is available online at: http://www.europarl.europa.eu/summits/hel1_en.htm)

144،"Membership requires that a candidate country achieve stability of institutions guaranteeing democracy, the rule of law, human rights, respect for and protection of minorities, the existence of a functioning market economy as well as the capacity to cope with competitive pressure and market forces within the Union. Membership presupposes the candidate's ability to take on the obligations of membership including adherence to the aims of political, economic and monetary union." The Copenhagen European Council, 2122 June 1993, Presidency Conclusions, paragraph 7. It is available online at: http://www.europarl.europa.eu/summits/copenhagen/co_en.pdf
} 
Partnership that set short and medium-term reforms to prepare Turkey fulfilling the Copenhagen criteria, (ii) monitoring Turkey's progress in meeting the criteria through annual progress reports, and (iii) the provision of financial assistance to handle the preaccession tasks that require satisfying the political criteria and aligning Turkey's legislation with the EU acquis.

Turkey has responded to the EU's pre-accession strategy through the National Programmes for the Adoption of the Acquis (NPAA; 2001, 2003, and 2008), the EU Harmonization Law Packages (or the EU reform packages), and the constitutional amendments. The eight EU reform packages from 2002 to 2004 involved a total of 490 laws, which were adopted or amended by the Turkish Parliament in order to fulfill the Copenhagen political criteria, and then to launch the accession talks. As a result, Turkey realized an unprecedented level of political reforms in the years of 2001-04. For many domestic and international observers of Turkish politics, the pace of reforms in these years represented a "silent revolution" in the country. ${ }^{145}$ In contrast to the pre-1999 period, the European Union executed a great leverage on Turkey's domestic politics in the aftermath of the historic Helsinki decision, which provided a credible prospect for EU membership. Through the pre-accession strategy, the EU played a significant role in the making of extraordinary legal and constitutional reforms that also involved changes concerning the protection of fundamental rights and liberties, human rights, and minority rights.

\footnotetext{
${ }^{145}$ For example, "Turkey's 'silent revolution' paves way for accession talks”, Martti Ahtisaari, European Voice, September 2 2004. Available online at: http://www.europeanvoice.com/article/imported/turkey-ssilent-revolution-paves-way-for-accession-talks/50538.aspx
} 
As stated earlier, the 1982 constitution and its statist/nationalist character put serious restrictions on fundamental rights and liberties. Article 13 in the constitution gave priority to the state over the individual, and set a wide restrictive clause against the full enjoyment of fundamental rights. As a result, the 1982 constitutional order left a very limited scope for fundamental rights, including the freedoms of thought, expression, association, assembly, demonstration, and the press. The scope of freedoms was further restricted in the South-East provinces, which remained under state of emergency from 1987 to 2002 due to the armed conflict with the PKK.

Through eight EU reform packages (2002-2004), two constitutional amendments (2001, 2004), and the adoption of new Civil and Penal Codes (2001, 2004), the protection of fundamental rights and liberties has become increasingly aligned with the EU norms and practices. The EU reform packages involved changes in major laws (the Penal Code, the Civil Code, the Anti-Terror Law, the Associations Law, the Press Law, the Political Parties Law, the Code on Criminal Procedure, and the Code on Civil Procedure etc.), and expanded the scope of fundamental rights and liberties. The 2001 Constitutional Amendment, which involved changes in more than one fifth of the 1982 constitution, transformed Article 13 from an excessively restrictive clause to a protective one for the protection of fundamental rights and liberties. The 2004 Constitutional Amendment included a change to Article 90 which states that international agreements shall take precedence in a case of a conflict between domestic laws and the international agreements concerning fundamental rights and liberties. The fifth and seventh EU reform 
packages (January and June 2003) provided re-trial rights for the civil, criminal, and administrative law cases in line with the ECHR rulings. ${ }^{146}$

In contrast to the discouraging previous $(1998,1999$, and 2000) reports, the European Commission acknowledged Turkey's reforms in the area of fundamental rights in 2001, 2002, and 2003. Nevertheless, the Commission did not find Turkey fulfilling the political criteria until the October 2004 report. In particular, the 2002 and 2003 reports underlined that Turkey's legal reforms in this area need further improvements along with the effective implementation. Thereafter, the Turkish government paid more attention to implementation, and established a Reform Monitoring Group in October 2003. ${ }^{147}$ The Copenhagen European Council of December 2004 decided in favor of beginning accession negotiations on the basis of an assessment that Turkey fulfilled the political criteria. The Commission's judgment confirmed that Turkey had realized substantial progress concerning the protection of fundamental rights and liberties. In parallel with the Commission's view, the Freedom House upgraded Turkey's civil liberties scale to 3 in 2005 while it was 5 for the years of 1995-2002, and 4 for 2003-2004 ( 1 to 7 scale; 1 most free, 7 least free).

The EU's pre-accession strategy following the Helsinki candidacy decision also resulted in important progress in the realm of human rights. The EU's monitoring on Turkey's human rights performance pushed Turkey to realize substantial reforms. The Commission's annual progress reports (1998-2003) listed numerous human rights

\footnotetext{
${ }^{146}$ The European Union set compliance with the ECHR rulings as a material condition for the EU membership.

${ }^{147}$ The Reform Monitoring Group (RMG) is composed of key ministers including the justice, interior, foreign, and the EU affairs.
} 
problems in Turkey: pervasive cases of torture, prison conditions, persistent human rights violations, extra-judicial executions, the State Security Courts (SSCs), the death penalty, ill-treatment in custody, detention procedures, and non-compliance with the ECtHR rulings. Following the announcement of the NPAA (National Programme for the Adoption of the Acquis) in March 2001, Turkey undertook several important reforms in the period of 2001-2004 to meet the EU's conditionality: the state security courts and the death penalty were abolished, a "zero-tolerance policy" against torture was launched, the security officers received extensive human rights training, pre-trial custody conditions were improved, the security officers were removed from local human rights councils, new institutions were established at the legislative and executive level to strengthen investigation of human rights violations, re-trial rights were provided for the cases where the ECtHR convicts Turkey, and legislative/constitutional changes were made in favor of gender equality. ${ }^{148}$ In addition, Turkey ratified the International Covenant on Civil and Political Rights-ICCPR (2004), the Convention on the Elimination of Discrimination against Women-CEDAW (2003), and the ECHR's Protocols 6 and 13 (on death penalty; 2003-04). Turkey's progress in the realm of human rights through these changes played an important role for EU reaching a decision to launch accession talks.

The post-Helsinki period of accelerated political reforms also had positive repercussions in the realm of minority rights. The reforms in the realm of fundamental rights and human rights were beneficial for Turkey's ethnic and religious minorities. In

\footnotetext{
148 The EU's annual progress reports from 1998 to 2003 noted several deficiencies in the realm of women's rights in Turkey: domestic violence in family, honor killings, legal discriminations between men and women, low percentage of women labor force (around 25\%), and low ratio of women MPs in the Turkish Parliament. The 2003 and 2004 regular reports confirmed Turkey's achievement in undertaking several reforms in this area, particularly with the 2001 constitutional amendment, the renewed Civil Code (2002), and changes in the Penal Code.
} 
this regard, the expanded scope of fundamental rights and liberties, the elimination of State Security Courts, re-trial rights in line with the ECtHR rulings, and zero-tolerance policy against torture were important changes for Turkey's Kurdish and non-Muslim minorities. In addition, the EU reform packages and the constitutional elements (200104) involved significant reforms specific to minority rights. Particularly notable, broadcasting in non-Turkish languages, including Kurdish (a taboo item, especially for the Turkish military), was legalized to fulfill the Copenhagen political criteria. For most domestic and international observers of the Turkish politics, the Kurdish broadcasting could have been hardly possible without the clear EU conditionality set through the Accession Partnership documents $(2001,2003)$. In combination with the reforms concerning the expansion of freedoms of thought, expression, assembly, and demonstration, the right to broadcast in non-Turkish languages has been an important step for the official recognition of Kurdish identity in the country. Despite these improvements, Turkey has not yet ratified the Council of Europe's Framework Convention for the Protection of National Minorities (FCPNM), as insisted by the EU (since 2002).

Moreover, the EU related political reforms have extended the property rights of non-Muslim community foundations to a great extent. In addition, the reforms made the establishment of worship places in private buildings possible for the non-Muslim minorities. Apart from these limited changes, the EU accession process linked by the Copenhagen political criteria has created a favorable milieu for better protection of the rights of ethnic and religious minorities in the country. 
The 1999-2004 and the 2005-present periods involve a major variation in terms of the EU's contribution in the realm of fundamental rights and liberties. In the first period, the EU made a substantial impact on Turkey's political reforms, which were mainly undertaken to meet the Copenhagen political criteria. Particularly, the 2001-2004 years witnessed an exceptional momentum of reforms in the history of Turkish democracy. Some domestic observers of Turkish politics have found these reforms as important as the Europeanization reforms of the early Republican period. The 1999-2004 period involved a critical shift in the Turkey-EU relations: the EU's credible commitment to Turkey's membership generated major legislative and constitutional reforms. These moved Turkish democracy closer to the European standards of fundamental rights and liberties as well as of human and minority rights. Since Turkey was required to fulfill the Copenhagen political criteria in order to launch the accession talks (precise conditionality supplemented with the EU's credible commitment), the EU's leverage on Turkey's democratization reforms was most visible in this period.

The subsequent period of accession negotiations (2005-present), in contrast, witnessed a declining prospect for EU membership and a slowdown of the political reforms. Therefore, the 1999-2004 and the 2005-present periods show a remarkable variation in the impact of EU on Turkey's democratization reforms. After the Copenhagen decision of launching accession talks, the European Union continued to monitor Turkish democracy in line with the political criteria; but the EU's requests for deeper legislative reforms and better implementation failed to generate the previous level of impact. 
As outlined in the Turkey-EU Negotiation Framework document (October 2005), the EU put extra conditions for Turkey as compared to the previous CEE candidates. The document explicitly stated that the accession talks with Turkey will be open-ended. In addition, it made possible the permanent derogations on free movement of Turkish people and on European assistance to Turkey from the EU's regional funds. These extra conditions blurred Turkey's prospect of the EU membership. In December 2006, the European Union partially suspended the accession talks (put hold on eight chapters) with a reason that Turkey had not yet implemented the Ankara Protocol (signed in June 2005), for opening of its ports and airports to trade from Cyprus. ${ }^{149}$ In addition, France and Cyprus put hold on the negotiation of additional eleven chapters.

As a result, the Turkey-EU accession negotiations experienced a serious deadlock, with nineteen chapters blocked from opening for negotiatiations. The declining prospect for membership considerably limited the EU's democratizing leverage in the 2005present period. Several fundamental crises in Turkey's domestic politics in 2007 and 2008 also led to the slowdown of democratization reforms. The presidential election crisis (2007), which involved the military's intervention in the election process through an online memorandum, and the closure case of the governing Justice and Development Party (2008) retarded the EU promoted political reforms.

Despite the slowed down pace of political reforms after 2005, the post-Helsinki period of democratization has not experienced a reversal. In this period, Turkey has made some improvements in regard to the protection of fundamental rights and liberties along

\footnotetext{
${ }^{149}$ The suspended eight chapters include Free Movement of Goods, Right of Establishment and Freedom to Provide Services, Financial Services, Agriculture and Rural Development, Fisheries, Transport Policy, Customs Union and External Relations.
} 
with establishing better standards of human and minority rights. Although the accession talks with the EU experienced a partial suspension, the EU's pre-accession mechanisms still pushed for reforms. The European Union continued to monitor democracy and human rights in Turkey in line with the political criteria, and asked for further changes as outlined in the revised Accession Partnership (AP) documents and the annual progress reports (2005-2011). ${ }^{150}$ The 2006 and 2008 AP documents set out several reforms to be undertaken. ${ }^{151}$ The regular reports in this period maintained a view that Turkey had fulfilled the Copenhagen political criteria but also provided major criticisms in the following areas: freedom of expression, ethnic and religious minority rights, and compliance with the ECHR and the ECtHR case law. In the years after 2005, Turkey undertook some reforms but at a slower pace as compared to 2001-2004. ${ }^{152}$

The author's field study in Turkey (November 2009 through January 2010) generated several helpful observations. In regard to the impact of the EU accession process for Turkish democracy, some interviewees discussed the EU's 'catalyst',

\footnotetext{
${ }^{150}$ The Accession Partnership documents and the Regular Reports are available online at: http://ec.europa.eu/enlargement/candidate-countries/turkey/key-documents/index_en.htm

${ }^{151}$ These reforms included as follow: training of judges and prosecutors in line with the ECHR and the ECtHR case law, human rights training of law enforcement officials, better observance of international human rights law through the ratification of ICCPR and the ECHR additional protocols, establishment of an independent human rights institution to monitor human rights cases, effective implementation of zerotolerance policy against torture, adoption of legal changes addressing non-Muslim religious minorities, and guaranteeing the right to broadcast in non-Turkish languages.

${ }^{152}$ Major reforms that Turkey realized in this period included the amendment to the penal code (article 301) in favor of a broader scope of freedom of expression, the human rights training of law enforcement officials, the training of prosecutors and judges for the ECHR and the ECtHR case law, growing public attention to women's rights, positive discrimination measures for women (the 2010 constitutional amendment), and the constitutional right to apply to the Turkish Constitutional Court concerning fundamental rights and liberties. In addition, the Reform Monitoring Group of the Turkish government has continued to work to maintain the effective implementation of the democratization and human rights reforms.
} 
'accelerating', and 'transforming' role for the 1999-2004 reforms. ${ }^{153}$ An anonymous diplomat from the Ministry of Foreign Affairs stated that the EU accession process is extraordinarily helpful for Turkey's democratization reforms. Professor Cengiz Aktar from Bahcesehir University argued that the Helsinki candidacy decision resulted in the acceleration of Turkey's transformation, and that the post-2001 reforms are important as much as the early Republican reforms of the Ataturk era (1923-38). Professor Aktar contended that Turkey could not have realized these reforms without the EU drive. Professor Atilla Eralp from the Middle East Technical University also agreed with this view. In a similar vein, Professor Ziya Onis from Koc University argued that undertaking these reforms could have taken a far longer time without a push from the EU.

Professor Ali Carkoglu from Sabanci University considered the EU accession process as the most important project for Turkey as the EU has a system transforming power. Murat Mercan (Member of Parliament from the Justice and Development PartyJDP) and Ersin Kalaycioglu (Professor of Political Science at Sabanci University) argued for the complementary and parallel nature of the two processes: European integration and democratization. Ufuk Uras, a social democratic member of the parliament, contended that the EU accession process has been helping Turkey to move from the military tutelage of the September 12 (1982) regime. Professor Ziya Onis and Lutfi Elvan (Member of Parliament from the JDP) noted the critical importance of the EU's drive for the reforms as regards the contention between the reformist and the status quo sections of the political landscape. Ege Erkocak from the Secretariat General for EU affairs, Professor Ziya Onis, and Professor Atilla Eralp argued that the EU accession process has expanded the scope

${ }^{153}$ The interviews with Ege Erkocak, Seyfi Tashan, Cengiz Aktar, Ziya Onis, Murat Mercan, and Muhittin Ataman 
of public debate on the formerly taboo issues such as the Kurdish question and the political behavior of the Turkish military.

Moreover, many interviewees underlined the significant role of EU reform packages and the constitutional amendments (2001-04), and they noted the following areas as key EU contributions: protection of fundamental rights and liberties (particularly the freedoms of thought, expression, and assembly), fight against the use of torture, the rule of law, the superiority of international agreements over domestic law, the human rights training of security officials, the ECtHR training of prosecutors, re-trial rights, pretrial detention conditions, human rights, the rights of ethnic and religious minorities, tolerance to ethnic, cultural, and religious differences, and the elimination of discriminations among citizens. ${ }^{154}$ In addition, several interviewees argued that Turkey's involvement in the structure of the European Court of Human Rights has been very helpful for the protection of fundamental rights, liberties, and human rights. ${ }^{155}$

Although the interviewees agreed that the EU's impact has been significant, they also shared concerns about its limitations. The anonymous diplomat, Professors Carkoglu and Aydin suggested that Turkey's domestic dynamics of democratization have also been important despite the fact that they agreed on the EU's positive contributions. Seyfi Tashan from the Ankara based Foreign Policy Institute, Professor Onis, Professor Ali Karaosmanoglu from Bilkent University, Professor Ali Resul Usul from Bahcesehir University, Ufuk Uras, Ahmet Kenan Tanrikulu (Member of Parliament from the

\footnotetext{
${ }^{154}$ The interviews with Ege Erkocak, Seyfi Tashan, Ali Carkoglu, Senem Aydin, Ali Resul Usul, Saban Disli, Ufuk Uras, Lutfi Elvan, Burhan Kuzu, Huseyin Pazarci, Akin Ozcer, Berdal Aral, Muhittin Ataman, and an anonymous diplomat from the Turkish Ministry of Foreign Affairs.

${ }^{155}$ The interviews with Yilmaz Ensaroglu, Seyfi Tashan, Burhan Kuzu, and Huseyin Pazarci.
} 
Nationalist Action Party), Ziya Muezzinoglu (a former Minister of Finance), and

Professor Hakan Yilmaz from Bogazici University suggested that the EU's democratizing impact has currently been very limited as compared to the 1999-2004 period. In this regard, Turkey's declining prospect for membership and the EU's unfair policies towards Turkey were raised as the major reasons behind the weakening of EU's democratizing leverage in the post-2005 period. ${ }^{156}$

Several interviewees raised criticisms in regard to the top-down nature of the EU driven reforms in particular and the EU's democratic conditionality in general. ${ }^{157}$ Yilmaz Ensaroglu from the Ankara based think tank SETAV argued that the EU reforms packages involved serious deficiencies, as some legislative changes were not substantial. He provided an example that the High Criminal Courts replaced the State Security Courts due to EU pressure but the new Courts continued to work with the same staff and function. Professor Hakan Yilmaz contended that the EU excessively relegated democracy into formality as it has failed to generate consistent and comprehensive criteria in assessing democracy and human rights in the candidate countries. For example, the EU regular reports have covered problems of some minority groups in Turkey while leaving out others in an inconsistent manner. In addition, Professor Yilmaz raised that the excessive reliance on the EU accession process for democratization reforms is highly risky, as failure in the accession process may also impede democratization to a great extent.

\footnotetext{
${ }^{156}$ Professor Ridvan Karluk from Anadolu University, who is an expert on the Turkey-EU relations and a pro-EU person, argued that the EU's unfair and discriminatory policies towards Turkey have made even 2023 as an unrealistic date for Turkey's EU membership. Mustafa Kaya from the Saadet Party too criticized the EU for her unfair policies towards Turkey.

${ }^{157}$ For example; Mustafa Kaya, Ziya Onis, and Hakan Yilmaz.
} 


\section{High prospects of regime survival and civilian control of the military}

Although Turkey experienced several democratic elections and maintained a parliamentary democratic system for most of the past six decades, both domestic and international observers of Turkish politics agree that the country has not consolidated democracy yet. A major problem in this regard has been the lack of civilian control of the military in line with democratic standards. The 1960, 1971, and 1980 direct military interventions, the 1997 and 2007 indirect interventions, and other forms of military involvement in politics made Turkish democracy highly vulnerable in terms of the third component of democratic consolidation. In the past decade, Turkey has achieved several legislative and constitutional reforms to realize democratic civil-military relations. These reforms have been possible to an important extent because of Turkey's efforts to fulfill the EU's Copenhagen political criteria. Despite these reforms, Turkish democracy still needs to take further steps to realize the civilian control of the military as suggested by the EU's annual progress report (November 2010) ${ }^{158}$. The ongoing Ergenekon investigation on several coup plots prepared in the years 2002-2004 demonstrates that the survival of Turkey's democratic regime was at serious risk even when the country was undertaking wide-ranging democratic reforms for the opening of accession negotiations with the EU.

The politicization of the Turkish military is not a recent phenomenon as it has long historical antecedents. In this regard, one has to examine the political role of the military during the late Ottoman and the early Republican periods. In the $18^{\text {th }}$ and $19^{\text {th }}$ centuries, military modernization constituted the initial components of the state-centered

${ }^{158}$ The European Commission, Turkey 2010 Progress Report, p.10-12. It is available online at: http://ec.europa.eu/enlargement/pdf/key_documents/2010/package/tr_rapport 2010_en.pdf) 
Europeanization/Westernization efforts. In the late $19^{\text {th }}$ and early $20^{\text {th }}$ centuries, the military officers who got their education in the newly designed military academies, took an active part in politics. In the declaration of the first constitution (1876) and its reactivation in 1908, an influential cadre of military officers played a decisive role (Hale 1994: 161, Biltekin 2007: 83-91). The politicization of the military was most visible in the 1908 military revolt against Sultan Abdulhamit II, which paved the way for the Second Constitutional Monarchy and the Committee of Union and Progress (CUP) rule (1908-18). In the last decade of the Ottoman State, three military generals in the CUP (Enver, Talat, and Cemal Pashas) became the most influential political figures in domestic politics and foreign policy. As a result, the late Ottoman period was an era of high level of politicization of the military.

The War of Independence following the collapse of the Ottoman State provided a large amount of respect to the military among both secular and conservative sections of Turkish society (Biltekin 2007: 91). The military remained in firm civilian control during the Ataturk period (1923-38). Deriving lessons from the late Ottoman years in which military's involvement in politics resulted in failures in the Balkan Wars and the First World War, Ataturk was convinced that the military had to be kept apart from politics. In addition, many scholars argue that Ataturk's insistence on civilian control during his term also had important pragmatic concerns. Ataturk prevented his rival military generals (Kazim Karabekir, Ali Fuat Cebesoy, Rauf Orbay, Refet Bele, i.e.) to challenge his leadership through two basic means: (i) the military officers were not allowed to engage in politics, and (ii) even if the military officers got involved in politics after relinquishing their army posts, the one party rule would not allow the survival of oppositional parties 
(Rustow 1959: 547-9, Ahmad 1993: 56-64; 2008:105-7, Hale 1994: 75-6). ${ }^{159}$ These two strategies, along with Ataturk's charismatic leadership, made the military a central actor for the protection of the Ataturkist/Kemalist principles- republicanism, progressiveness, populism, secularism, nationalism, and statism. In the aftermath of Ataturk's death, the army's 'guardianship mission' set the stage for a military's frequent involvement in politics in the future (Guney and Karatekelioglu 2005: 441-43, Narli 2005: 230-32).

While this brief historical overview provides some clues about the origins of the politicization of the Turkish military, an analysis of the legal prerogatives gained through the 1960,1971 , and 1980 military interventions are also essential to understand why civilian control of the military was a missing component of Turkish democracy in 19602000. This analysis will also be helpful to see the significance of recent civil-military relations reforms, which were made to fulfill the Copenhagen political criteria.

While the 1960 and 1980 military interventions resulted in the making of new constitutions, the 1971 intervention paved the way for a major constitutional amendment. In the 1961 constitution, the National Security Council (NSC) was established to 'communicate the requisite fundamental recommendations to the Council of Ministers with the purpose of assisting in the making of decisions related to national security and coordination' (Article 111). The NSC was arranged to meet monthly. Particularly important, the NSC provided constitutional justification for the military's involvement in domestic political matters through a broad conception of 'national security' (de Castro 2010: 49). The 1961 Internal Service Law of the Turkish Armed Forces (TAF) set the duty of the TAF as 'to protect and preserve the Turkish homeland and the Turkish

\footnotetext{
159 Terakkiperver Cumhuriyet Firkasi (the Progressive Republican Party) was established by these prominent generals in November 1924; however, it was closed down in June 1925.
} 
republic as defined in the constitution' (Article 35). According to the Internal Service Regulations of the TAF (Article 85/1), the military 'shall defend the country against the internal and external threats, if necessary by force' (Heper and Guney 2000: 637). ${ }^{160}$ The 1961 constitution also made the Chief of General Staff directly responsible to the prime minister instead of to the minister of defense (Article 110). The currently active arrangement has enhanced the political autonomy of the TAF, and made the civilian control more difficult (Bayramoglu 2009: 82-87, Yazici 2009: 83-4). Moreover, the 1960 military intervention resulted in the establishment of the Armed Forces Pension Fund (OYAK) to improve the economic and social status of the military officers. ${ }^{161}$ The Fund has later become a key instrument of the military's extensive involvement in the economic realm as a reflection of its political autonomy (Cizre 2002: 175 cited in Akca 2009: 263).

The 1971 intervention, which ousted the government through a memorandum, enhanced further the institutional and political autonomy of the TAF. Amendment to the NSC law provided the Council more important role in the shaping of security policies. The amendment also made the Land, Air, and Naval Commanders the NSC members (de Castro 2010: 10-14, 49, Bayramoglu 2009: 80). Two legal changes in this period made the Chief of General Staff more autonomous entity from the ministry of defense. The

\footnotetext{
${ }^{160}$ The full-texts (in Turkish) of the Internal Service Law and the Internal Service Regulations of the TAF are available online at the websites of the Justice Ministry and the Office of Prime Minister: http://www.mevzuat.adalet.gov.tr/html/1044.html and http://mevzuat.basbakanlik.gov.tr/Metin.Aspx?MevzuatKod=7.5.5905\&MevzuatIliski=0\&sourceXmlSearc $\mathrm{h}=\mathrm{T} \% \mathrm{C} 3 \% 9 \mathrm{CRK} \% 20 \mathrm{~S} \% \mathrm{C} 4 \% \mathrm{~B} 0$ LAHLI $\% 20$ KUVVETLER $\% \mathrm{C} 4 \% \mathrm{~B} 0 \% 20 \% \mathrm{C} 4 \% \mathrm{~B} 0 \% \mathrm{C} 3 \% 87 \% 20 \mathrm{H} \% \mathrm{C} 4$ \%B0ZMET\%20Y\%C3\%96NETMEL $\% \mathrm{C} 4 \% \mathrm{~B} 0 \% \mathrm{C} 4 \% 9 \mathrm{E} \% \mathrm{C} 4 \% \mathrm{~B} 0$.

${ }^{161}$ Through extensive tax privileges and other exclusive rights, the economic volume of the Fund has expanded to an extent that it has become one of the top economic entities in the Turkish economy.The OYAK involves multiple enterprises including supermarkets, real estate, shares, insurance, and automotive industry. Taha Parla considers the OYAK enterprise as a case for 'mercantalist militarism' (Parla 2009: 201-24, Akca 2009: 225-69, Ahmad 2008: 152-3, de Castro 2010: 7).
} 
Chief of Staff was set as the major holder of determining defense policy, military budget, intelligence gathering, internal security, procurement of arms, and military appointments (Cizre 1999: 72-3, 1997: 159). Moreover, the 1971 intervention resulted in the creation of the High Military Administrative Court (AYIM), which replaced the Council of State to prosecute civilians who offend military personnel. The military courts gained legal authority to try civilians for non-military crimes. As a result, the TAF did have further privileges in the judicial system at the expense of the civilian courts. In addition, the 1971 intervention resulted in the creation of the State Security Courts, which included both the civilian and military judges/prosecutors to deal with crimes against state security. Finally, an amendment to the constitution exempted the TAF from the supervision of the Court of Audits (Yazici 2009: 88-92, Bayramoglu 2009: 79-82).

The September 12, 1980 military coup even further expanded the political autonomy of the Turkish military, and made it a central actor in the Turkish politics. The 1982 constitution made during the 1980-83 military rule substantially limited the scope of fundamental rights and liberties as compared to the 1961 constitution (Cizre 1997: 156, Narli 2005: 239, Bayramoglu 2009: 82-4). ${ }^{162}$ The constitution increased prerogatives of the National Security Council. ${ }^{163}$ Later, the Council took decisions in a broad range of

\footnotetext{
${ }^{162}$ The Chief of General Staff Kenan Evren, who headed the coup in cooperation with the four service commanders, later became the president for seven years (1982-89). As a reflection of the army's central role in the history of Turkish politics, the country witnessed the first civilian president (Turgut Ozal, 198993) only sixty-six years after the foundation of the Republic. All the former seven presidents including the founder Kemal Ataturk were military generals.

${ }^{163}$ The Council of Ministers was required to 'give priority consideration to the decisions of National Security Council' (Article 118). The revised NSC law defined national security in broad terms, and authorized the NSC to monitor and evaluate a wide spectrum of policies. In addition, the revised law changed the civilian-military ratio (4 to 5) of NSC members in favor of the military side. The NSC Secretary has been appointed only from the military officers until 2004 while the Secretariat has been predominantly composed of the military personnel. The NSC Secretariat has acquired a unique leverage to
} 
military issues including school curriculum/education, tv broadcasting rights, bureaucratic appointments in the state ministries, political party alignments before the elections, foreign trade, development of energy sector, economic plans, and agricultural development projects (Cizre 1997: 157-8, Biltekin 2007: 64). ${ }^{164}$ Furthermore, the military has continued to remain outside of the supervision of the Court of Audits. The constitution exempted the Supreme Military Council (YAS) decisions from the judicial review (Yazici 2009: 94-8). As a result of all these changes, the Turkish military has found a more favorable constitutional basis not only to maintain its institutional and political autonomy but also to interfere in politics. In the February 28 (1997) process, the Turkish military ousted the Welfare-True Path coalition government without making a coup; rather, it used constitutional institution of the National Security Council for this purpose. ${ }^{165}$

The area of civil-military relations posed a major challenge for Turkey's bid for EU membership in the post-Helsinki period. The EU's Copenhagen political criteria required that Turkey should align its civil-military relations with the practices in the EU member states. To fulfill the political criteria, Turkey undertook several reforms in this area since 2001. Although these reforms have not yet paved the way for civilian control of the magnitude in consolidated democracies, the EU's push resulted in significant

gather intelligence and information from the civilian state institutions (Heper and Guney 2000: 637, de Castro 2010: 49, Bayramoglu 2009: 84-97).

164 The 1982 constitution also authorized the Chief of Staff to appoint a member for the newly established Higher Education Council, which is responsible for the supervision of universities in the country.

${ }^{165}$ In the February 28, 1997 NSC meeting, the military generals including the Chief of Staff and the four service commanders forced the civilian government to implement eighteen decrees to protect the secular character of the regime. In addition, the military headed a political campaign in cooperation with the press, business, and civil society. The head of the government, pro-Islamic Necmettin Erbakan, resigned on June 18, 1997. On the February 28 process, see Cizre and Cinar 2003, Bayramoglu 2009: 97-105, Taspinar 2004, Heper and Guney 2000, Dagi 2001, and Insel 2003. 
improvements. The EU's impact was most visible in 2001-04, while the subsequent period of slowdown in the Turkey-EU relations has limited the EU's leverage.

Nevertheless, the ongoing Turkey-EU accession negotiations have been helpful to some extent for the civilian government's reform efforts in most recent years.

In line with the EU's conditionality, Turkey undertook several important civilmilitary relations reforms in the 2001-04 period. The October 2001 constitutional amendment increased the civilian members of the NSC; then, the numbers of civilian members exceeded the military ones. The sixth EU harmonization law package (July 2003) removed the military member of the High Audio-Visual Board (RTUK), which monitors tv and radio broadcasts in the country. The seventh EU reform package (August 2003) included substantial changes concerning the duties and functioning of the National Security Council: the NSC discretion on which languages to be taught in schools eliminated, the frequency of NSC meetings reduced from monthly to bi-monthly intervals, the prerogative of the Chief of Staff to convene a NSC meeting removed, appointment of a civilian NSC Secretary made possible, and the right of the NSC to have an access to information from all public and private legal persons abrogated. All these changes have helped the transformation of the NSC from playing a dual executive role to an advisory body as required by the EU.

The seventh reform package included two other important changes in the realm of civil-military relations: the Court of Audits, on behalf of the parliament, got the authority to oversight the military expenditures, and the civilian courts instead of the military courts acquired the right to try civilian persons concerning offenses against soldiers or the military. The eighth EU harmonization law package (July 2004) involved a change in the 
higher education law that removed the right of the General Staff to appoint a member for the Higher Education Council (YOK). ${ }^{166}$ Moreover, the May 2004 constitutional amendment abrogated the State Security Courts (SSCs), which included the military judges and prosecutors until 1999. The SSCs had been severely criticized by the EU as they had several trials in conflict with the ECHR and the ECtHR rulings. In addition, the 2004 constitutional amendment strengthened the earlier changes concerning the removal of a military member in the YOK, and the supervision of the military expenses through the Court of Audits.

The 2001-2004 civil-military relations reforms, made to a great extent to satisfy the Copenhagen political criteria, represent a turning moment for the consolidation of Turkish democracy. Undertaking such unprecedented changes was certainly not easy. According to the diaries of the former Navy commander, the hardliner service commanders (the Air, Navy and Gendarmerie) organized several coup plots to overthrow the Justice and Development Party (JDP) government, which came into power after the November 2002 elections. ${ }^{167}$ The diaries show that the JDP's pro-Islamic/conservative identity, the groundbreaking approach to the Cyprus conflict, and the civil-military relations reforms created a backlash among the hardliner officers who have ultranationalist and anti-EU profiles. Nevertheless, as the diaries confirm, the Chief of Staff

\footnotetext{
${ }^{166}$ For the adoption date and the content of the EU Harmonization Law packages, see Political Reforms in Turkey, Ministry of Foreign Affairs, Republic of Turkey (Ankara, 2007), and 'Appendix 2: Laws Adopted by the EU Harmonization Packages' in Ozbudun and Genckaya 2009: 128-134.

${ }^{167}$ The diaries were first published in the Nokta Magazine on March 29, 2007. After the publication, the Nokta Magazine was closed down immediately with pressures from the military as noted by a report on the press freedom prepared by the Parliamentary Assembly of the Council of Europe, 'The Protection of Journalists' Sources', December 1, 2010

(http://assembly.coe.int/main.asp?Link=/documents/workingdocs/doc10/edoc12443.htm)
} 
(Hilmi Ozkok, 2002-06) stood against the coup attempts. For many observers of Turkish politics, Ozkok's pro-EU, democratic, and gradualist profile considerably facilitated undertaking these civil-military relations reforms. ${ }^{168}$

Although the 2001-04 civil military relations reforms were comprehensive, they have not been sufficient to prevent the military's intervention in politics. In the following years, the Turkish General Staff continued to make political statements concerning issues such as secularism, education, the Kurdish question, political elections, and foreign policy. Particularly notable, the General Staff issued an electronic memorandum on the eve of presidential elections in April 27, 2007. Expressing concerns with the JDP's decision to nominate then-Foreign Minister Abdullah Gul, whose wife wears a headscarf, the e-memo hinted that the military could intervene the electoral process as 'a legal duty of the Turkish Armed Forces' (referring to the TAF Internal Service Law, article 35) to protect the secular character of the regime. After the statement, the JDP government stood against the military, withdrew Gul's nomination, and called for early parliamentary elections to be held on July 22. Favored by a strong public reaction to the e-memo, the JDP increased its votes from 34 percent (in 2002) to the historic 47 percent, and the JDP's nominee (Abdullah Gul) was elected by the parliament as the new president on August 28, 2007. As a result, the military failed in its attempt to intervene the presidential elections while the April 27 e-memo became a turning point in the realm of civil-military relations. For the first time, the civilian government was able to stand against the military

\footnotetext{
${ }^{168}$ The former Prime Minister Mesut Yilmaz, who came into power after the military ousted the Erbakan government through the February 28 process, argued that the JDP could not have handled the civil-military relations reforms if Hilmi Ozkok was not serving as the Chief of Staff in this period. The interview with Mesut Yilmaz on HaberTurk TV, 'Refah-Yol Hukumeti Dik Durabilseydi...', January 27, 2011 (http://www.haberturk.com/gundem/haber/595697-refah-yol-hukumeti-dik-durabilseydi).
} 
with the help of a large section of the Turkish people and elite, including secular intellectuals. $^{169}$

Like the failed April 27 e-memo, the opening of Ergenekon investigation has been one of the key developments concerning the civilianization of Turkish politics in the recent years. ${ }^{170}$ The investigation started in June 2007 with the findings of 27 hand grenades stored in a house in Istanbul that linked to the bombings of Cumhuriyet newspaper in May 2006. Later, an army major, retired and active-duty military officers (including the former Gendarmerie commander and the NSC secretary), police officers, mafia leaders, journalists, academicians, businessmen, and ultra-nationalist political figures were arrested. The first indictment of Ergenekon, which was prepared by the Istanbul Prosecutor's Office (July 2008) charged 86 suspects with several allegations: membership in an armed terrorist organization, attempting to overthrow the civilian government by use of violence and coercion, inciting rebellion among people against the government, inciting disobedience in the military, acquiring illegally top secret official documents, and stocking/using explosive materials to commit crimes (Aydinli 2011: 22739, Unver 2009: 10). ${ }^{171}$ Although the Ergenekon trial process has been frequently

\footnotetext{
${ }^{169}$ A group of five hundred (mostly secular) intellectuals (academicians, journalists, lawyers, artists etc.) issued a statement against the e-memo. The statement suggested that the TAF's intervention through the ememo is a legal crime, and that it is a clear threat against Turkish democracy. The statement also called for the enactment of a new constitution as the 1980 coup product of the 1982 constitution was considered as a major reason for the military's frequent involvement in the political sphere. '500 aydından Genelkurmay muhtırasına karşı bildiri' ('500 intellectuals issued a counter statement to the General Staff's memortandum'), Radikal, May 14, 2007 (http://www.radikal.com.tr/haber.php?haberno=221188)

${ }^{170}$ Ergenekon is the name of an alleged clandestine, ultra-nationalist terrorist network.

${ }^{171}$ The Istanbul Prosecutor's Office opened the second and third indictments of the Ergenekon investigation in March and July 2009. The second indictment targets 56 suspects while the third one is concerned with 52 suspects. 'Ergenekon'da 2. İddianame açıklandı', Hurriyet, March 26, 2009 (http://www.hurriyet.com.tr/gundem/11286391.asp), 'Ergenekon'da 3. Iddianeme', July 21, 2009 (http://www.haberturk.com/gundem/haber/160029-ergenekonda-3-iddianame). Several major crimes in the
} 
criticized in regard to long detention periods and other trial procedures, a majority of the Turkish people agree that the Ergenekon is a terrorist organization (68 to 32 percent). ${ }^{172}$ Also, the event offered a great opportunity to eliminate Turkey's 'deep state', which poses a serious threat against the consolidation of Turkish democracy.

The EU's 2009 regular report on Turkey considered the Ergenekon trial as a 'first case to probe into a coup attempt and the most extensive investigation on an alleged criminal network aiming at destabilizing the democratic institutions', and as 'an opportunity for Turkey to strengthen confidence in the proper functioning of its democratic institutions and the rule of law' (p.6-7).

In July 2010, the Istanbul Prosecutor's Office accepted an indictment in regard to the Balyoz (Sledgehammer) coup plot, which was allegedly prepared in 2003 in the First Army (Istanbul). The Balyoz indictment charges 196 suspects including 19 retired and 28 active-duty generals for attempting to overthrow the government and the constitutional order. Among the suspects, the former air force and navy commanders along with the commander of the First Army also take place while 162 of 196 suspects have been arrested. ${ }^{173}$ The Balyoz coup plot includes actions such as the bombing of two major

country's recent past were attributed to the Ergenekon terror network: the assasinations of the Turkish Armenian journalist Hrant Dink, the Italian Bishop Santoro, and the armed assault on the Council of State (a senior judge was killed). 'Will Turkey Benefit from Ergenekon', Le Monde Diplomatique, November 2009 (http://mondediplo.com/blogs/will-turkey-benefit-from-ergenekon).

${ }^{172}$ GENAR Poll, November 2008. When asked about the nature of the Ergenekon trial, the respondents' views were as follow: The Ergenekon trial is "essentially political case" ( $65 \%$ no, $35 \%$ yes); the Ergenekon network 'protects the regime' ( $75 \%$ no, $25 \%$ yes); the Ergenekon is an 'interest oriented criminal group' ( $61 \%$ yes, $39 \%$ no); it aims at initiating a military coup ( $58 \%$ yes, $42 \%$ no). GENAR poll, July 2008 (Unver 2009: 21).

${ }^{173}$ On May 30 2011, the Commander of the Military Academies (General Bilgin Balanli) was arrested in connection with the Balyoz coup plot. General Balanli has been expected to be promoted to the Commander of Air Force in August 2011. For the first time in the country, an active-duty full general was arrested with an allegation of coup plotter. 
historical mosques in Istanbul, the toppling of a Turkish jet over Aegean to provoke a war with Greece, the realization of events to declare a martial law, and the formation of a military-directed cabinet of ministers (the names listed). ${ }^{174}$ In addition to the 2003 Balyoz coup plot, another one (Kafes-Cage, dated March 2009) was seized by the Ergenekon trial investigators in November 2009. The Navy based Kafes coup plot is alleged to overthrow the government through destabilizing actions including the assassination of prominent non-Muslim citizens in the country. ${ }^{175}$

The 2001-04 civil-military relations reforms, initiated to fulfill the Copenhagen political criteria, represented a significant change in the Turkish politics in favor of a civilian control of the military. Moving the NSC from dual executive institution to an advisory body, opening the process of parliamentary oversight over the military expenditures, and limiting the sphere of military courts in favor of the civilian courts were unprecedented changes. Particularly notable, the investigation of the alleged coup plots by the civilian courts- first time in the country-, was possible to a large extent because of the 2001-04 reforms. The EU accession process played a decisive role in undertaking these reforms.

Later, the slowdown in the Turkey-EU relations due to the partial suspension of the accession negotiations limited the EU's leverage in the realization of further progress in this area. Although annual reports by the European Commission (2005-10) and the European Parliament (2006-11) closely monitored Turkey, and demanded further reforms

\footnotetext{
${ }^{174}$ The allegations in the Balyoz indictment are based on 5000-page documents, which were published in the liberal daily Taraf on January 20, 2010. 'Darbenin adi Balyoz-The Name of Coup: Sledgehammer' (http://www.taraf.com.tr/haber/darbenin-adi-balyoz.htm). See also, 'The Turkish Army: Coups Away', The Economist, February 11, 2010 (http://www.economist.com/node/15505946? story id=15505946)

175 'Kod adi Kafes- The Code Name: Kafes', Taraf, November 19, 2009 (http://www.taraf.com.tr/haber/kod-adi-kafes.htm)
} 
in the realm of the civil-military relations, the EU's impact remained very limited as compared to the 2001-2004 period. As included in the 2006 and 2008 revised Accession Partnership documents, the EU had four major requests from Turkey in this area: (i) further alignment of the civilian control of the army in line with the practices in the EU member states (ensure that the military does not interfere in political affairs), (ii) increasing transparency and accountability in the conduct of security affairs, (iii) establishment of full parliamentary oversight of military and defense policies, and (iv) abolishing any remaining competence of military courts to try civilians. ${ }^{176}$ In the EU's progress reports, several criticisms have been directed: the unchanged article (35) of the TAF's Internal Service Law, which provides a legal justification for the army's interference in political affairs (2005-10 reports), the army's large influence in the political sphere (2005-09 reports), the broad definition of national security in the NSC law (2005-07 reports), the lack of progress in parliamentary oversight over military expenditures (2006-10 reports), and the existence of the 1997 EMASYA covert security protoco ${ }^{177}$, which enables the army to exercise military operations without the consent of civilian authorities (2007-09 reports). In contrast to the 2005-2008 reports, the 2009 and 2010 reports noted some positive developments: the ongoing process of the Ergenekon trial, the June 2009 legal change that allows civilian courts to try military officers

\footnotetext{
${ }^{176}$ The 2006 and 2008 Turkey-EU Accession Partnership documents are avilable online in the website of the EU: http://ec.europa.eu/enlargement/candidate-countries/turkey/key-documents/index en.htm

${ }^{177}$ The EMASYA protocol was signed in the aftermath of the 28 February 1997 military intervention between the Turkish General Staff and the Interior Ministry . The protocol has been criticized particularly because of its potential to provide a legal framework for a future coup. The EMASYA protocol was annulled on February 4, 2010. "The Turkish Army: Coups away", The Economist, February 11, 2010. (http://www.economist.com/node/15505946).
} 
concerning coup plots ${ }^{178}$, the removal of the EMASYA protocol, and the September 2010 constitutional amendment, which restricted the jurisdiction of military courts and enabled civilian courts to try military officers as regards coup attempts. ${ }^{179}$

During the author's field study, the interviewees expressed their views concerning the recent civil-military relations reforms, the EU's contributions in this area, possibility of a military coup in the country, and the need for further progress to maintain the democratic control of the armed forces. First of all, several interviewees noted that the realm of civil-military relations is one of the most deficient areas in terms of the consolidation of Turkish democracy. ${ }^{180}$ Many interviewees argued that the risk of democratic breakdown through a military coup still exists despite the fact that several civil-military relations reforms were made in the recent years. ${ }^{181}$ Seyfi Tashan underlined the significance of strong civilian leadership and civilian expertise in security affairs to uphold the civilian control of the military. Former diplomat Akin Ozcer argued that the lack of strong anti-coup public movements makes the military intervention more likely in the country. Ali Karaosmanoglu, Yilmaz Ensaroglu, and Berdal Aral noted that the military is not solely responsible for the interventions; rather, the pro-intervention civilians also have important role here. Hakan Yilmaz argued that the lack of trust and

\footnotetext{
${ }^{178}$ That arrangement was later annuled by the Turkish Constitutional Court following the application by the main opposition party (the Republican People's Party, CHP). However, the September 2010 constitutional amendment, which came into force after the referendum (September 12, 2010) limited the jurisdiction of military courts, and enabled civilian courts to try military officers in regard to coup attempts.

${ }^{179}$ The EU's regular reports on Turkey are available online in the website of the EU's Delegation to Turkey: http://www.avrupa.info.tr/AB ve Turkiye/Muzakereler,Regular Reports.html (1998-2010) ${ }^{180}$ Interviews with Lutfi Elvan, Ufuk Uras, Akin Ozcer, Ziya Onis, Ali Resul Usul, Yilmaz Ensaroglu, Berdal Aral, and Muhittin Ataman.

181 Interviews with Hakan Yilmaz, Yilmaz Ensaroglu, and Seyfi Tashan. Professors Ersin Kalaycioglu and Ali Carkoglu agreed for the existing risk of a further military coup but with a minimal possibility. An anonymous diplomat argued that Turkey's democracy no longer involves any risk of military coup.
} 
consensus among the major domestic groups (the military, nationalists, Kurds, and conservatives) enhances the risk of a military coup although the international context is currently unfavorable for a coup (neither the US nor the EU supports a military coup in the country).

In regard to the post-2001 civil-military relations reforms, several interviewees underscored the important role played by the EU accession process. ${ }^{182}$ Ufuk Uras contended that the EU accession process is critically important to relinquish the military guardianship of the post-September 12 (1982) political regime. Murat Mercan, Ziya Onis, and Ali Resul Usul argued that the 2001-04 civil relations reforms, which were made to fulfill the Copenhagen political criteria, have made possible the Ergenekon investigation of coup plots by the civilian courts. ${ }^{183}$ Ali Karaosmanoglu made a distinction between the 2001-04 and the 2005-present periods in terms of the EU's contributions to the civilmilitary relations reforms. Karaosmanoglu argued that the EU's leverage has remained very limited in the latter period due to the deadlock in the accession negotiations. Moreover, many interviewees argued that Turkish democracy has not yet fulfilled the third component of the consolidation, and that further progress is necessary in this area. $^{184}$

\footnotetext{
${ }^{182}$ Interviews with Saban Disli, Burhan Kuzu, Murat Mercan, Ali Karaosmanoglu, Ege Erkocar, Cengiz Aktar, Ziya Onis, Ali Carkoglu, Ali Resul Usul, Berdal Aral and Muhittin Ataman.

${ }^{183}$ Ersin Kalaycioglu, an anonymous law professor, and Senem Aydin criticized the Ergenekon investigation in respect to fair trial and detention procedures.

${ }^{184}$ Interviews with Lutfi Elvan, Ufuk Uras, Burhan Kuzu, Cengiz Aktar, Akin Ozcer, Ziya Onis, Ali Resul Usul, Senem Aydin, Yilmaz Ensaroglu, Berdal Aral, and Muhittin Ataman.
} 


\section{Legitimacy, anti-system parties, stateness}

The fourth component of democratic consolidation is composed of three parts: (i) democracy is considered as the best type of political regime by the majority of people, (ii) no politically significant group or political party works for an alternative political regime, and (iii) secession is not a serious matter in a multi-ethnic democracy. In consolidated democracies, the majority of people consider democracy as the best type of political regime; anti-system political parties or separatist groups either are absent or they fail to draw strong public support. Overall, the fourth component of the consolidation involves both attitudinal and behavioral dimensions.

In assessing Turkish democracy in the context of European integration (1999 to present), one can note that democracy in the country has enjoyed high public legitimacy, and that no anti-system political party exists but the Kurdish question has continued to pose a major challenge for the fourth component of consolidation. The following section will examine the major issues concerning public legitimacy, anti-system political parties, and stateness. In doing so, it will also assess the democratizing impact of European Union accession process.

\section{Public Legitimacy}

In the post-1950 period of multi-party democracy, the Turkish people have taken an active part in the democratic elections as seen in the high levels of turnout rates. The following table shows the participation rates from 1950 to 2011. 
Table 5.1: Participation in Parliamentary Elections, 1950-2011

\begin{tabular}{|l|l|l|l|l|l|l|l|}
\hline Year & $\begin{array}{l}\text { Participation } \\
\text { Rate (\%) }\end{array}$ & Year & $\begin{array}{l}\text { Participation } \\
\text { Rate (\%) }\end{array}$ & Year & $\begin{array}{l}\text { Participation } \\
\text { Rate (\%) }\end{array}$ & Year & $\begin{array}{l}\text { Participatio } \\
\text { n Rate (\%) }\end{array}$ \\
\hline 1950 & 90.4 & 1965 & 71.3 & 1983 & 92.3 & 1999 & 87.1 \\
\hline 1954 & 88.6 & 1969 & 64.3 & 1987 & 93.3 & 2002 & 79.1 \\
\hline 1957 & 76.6 & 1973 & 66.8 & 1991 & 83.9 & 2007 & 84.2 \\
\hline 1961 & 81.4 & 1977 & 72.4 & 1995 & 82.3 & 2011 & 87.4 \\
\hline
\end{tabular}

Source: Sayari and Esmer 2002: 189, and the website of Turkey's High Election Board (YSK) (http://www.ysk.gov.tr)

According to a major survey study, conducted with 1492 voting age individuals across the country through face-to-face interviews in May-June 2006, 76.9 percent of Turkish people believe that democracy is the best type of political regime ("Democracy may involve problems, but it is still much better than any other regime") (Carkoglu and Toprak 2007: 55). In the same study, the respondents provided high levels of support for the protection of basic rights and freedoms. ${ }^{185}$ Moreover, the 2006 survey showed a remarkable decline in the level of support for a Shari'ah (Islamic law) based political regime among the Turkish people as compared to the mid-to-late 1990s when the country witnessed the rise of political Islam. While surveys made in 1995, 1996, 1998, 1999, and 2002 involved $19.9 \%, 26.7 \%, 19.8 \%, 21 \%$, and $16.4 \%$ (respectively) support levels for

\footnotetext{
${ }^{185}$ In what follows, the responses to some survey questions concerning basic rights and freedoms take place: "Radical or marginal ideological groups should be allowed to demonstrate as long as they do not mar law and order" (57.1\% agree, 19.8\% disagree), "People should never be tortured during interrogations by police officers regardless of their criminal offence" (73.2\% agree, $14.6 \%$ disagree), "The freedom of people to use mother tongues, which they have learned from their parents, should not be constricted by any means" (76.1\% agree, 9.4\% disagree), "The freedom of people to practice any religion or lifestyle should not be limited by any means" (78.6\% agree, $8.2 \%$ disagree), "The freedom of people to express themselves freely should not be limited by any means" (79.9\% agree, 7.3\% disagree). Ali Carkoglu and Binnaz Toprak 2007, Religion, Society, and Politics in a Changing Turkey, a joint project by Friedrich Ebert Stiftung (FES) and Turkish Economic and Social Studies Foundation (TESEV). The survey study is available online at the website of TESEV: http://www.tesev.org.tr/UD_OBJS/PDF/DEMP/RSP\%20-\%20Turkey.pdf (114 pages).
} 
such a regime, in 2006 only 8.9 percent of the respondents answered affirmatively the question “would you want a Shari'ah-based religious regime to be established in Turkey”(Carkoglu and Toprak 2007: 81).

Particularly notable, the support for an Islamic political regime in a predominantly Muslim society declined when the conservative Justice and Development Party was in power as a single-power majority government after November 2002. In addition to the 2006 survey, many other studies reveal that the Turkish society has moved to a more religiously conservative line but this has not corresponded to an increasing yearn for an Islamic political regime or any disenchantment from the secular democratic regime. The people overwhelmingly support the secular regime but they also demand for a better protection of religious freedoms (Zurcher et al 2004: 58, Kalaycioglu 2010: 166-7, Carkoglu and Toprak 2007: 13-15, Ozbudun 2009: 36-39).

Although the 2006 survey demonstrated a high level of public commitment to secular democracy, it also showed that the majority of the Turkish people agree with the military's criticism of the civilian government ("it is natural for the military to occasionally voice their opinion against an elected government"; 58.6\% agree, $18.4 \%$ disagree) while about a quarter of the people only prefer a military regime over the democratically elected government (“Turkey’s problems can be solved not by elected governments but by a military regime"; $26.8 \%$ agree, $54.7 \%$ disagree). In addition, a quarter of the Turkish people disagrees with the statement that "Turkish people can safeguard secularism without the support of the military" (53.7\% agree, $24.8 \%$ disagree) (Carkoglu and Toprak 2007: 83). Having considered the civilian control of the army as one of the central issues for the consolidation of Turkish democracy, such levels of public 
support for a military's engagement in politics could complicate the process of democratic consolidation. $^{186}$

The Turkish people perceive the European Union as symbolizing modernization, democracy, respect for human rights, and peace. ${ }^{187}$ Although Turkish people considered the country's EU membership less 'as a good thing' in $2010(42 \%)$ than in $2004(71 \%)$, which reflects the stalemate in the Turkey-EU accession negotiations, a recent poll (May 2011 ) shows that a majority (69\% support, $26 \%$ oppose) desire accession for Turkey to the EU. ${ }^{188}$ There has been no obvious impact of the EU accession process on the degree to which the democratic regime receives public legitimacy, yet the wide convergence of Europeanization and democratization processes has generated indirect effects.

Particularly notable, the European integration process has helped moderation of the political Islamist constituents of the governing Justice and Development Party, which has shown a strong commitment to EU membership. Overall, the people's positive assessment of the EU in regard to democracy and human rights has made the accession process indirectly supportive of the legitimacy of Turkish democracy.

\footnotetext{
${ }^{186}$ A discourse analysis study on the four major political groups (Kemalist, Nationalist, Liberal Left, and Islamist) in the country has argued that the liberal left and the Islamist discourses widely reject the notion that "the army is the guarantor of democracy and secularism", and that the Kemalist discourse remained neutral while the nationalist discourse involved a high level of support for the army's guardianship role (Kanra 2009: 113-30). On the other hand, the 2006 survey showed that people with Kurdish origin take a more oppositional stance against a military regime $(71 \%$; 18 percent higher than the country average (53.7\%) (Carkoglu and Toprak 2007: 84-5).

${ }^{187}$ Standard Eurobarometer 74, November 2010; Turkey Report. It is available online at the website of the EU: http://ec.europa.eu/public_opinion/archives/eb/eb74/eb74_en.htm

${ }^{188}$ Akgun, Mensur et al 2011, Turkiye'de Dis Politika Algisi (Foreign Policy Perceptions in Turkey), TESEV-Open Society Foundation., p.14 (It is available online at: http://www.tesev.org.tr/UD_OBJS/PDF/DPT/OD/11256DisPolitikaAlgiWEB01 06 11.pdf. The poll has also revealed that the majority of people do not expect Turkey's accession in the short-to-middle run period. ('prospective date of Turkey's accession?': in 5 years (16\%), in 5-10 years (20\%), in 11-20 years $(8 \%)$, after 20 years $(5 \%)$, never $(30 \%)$, rejected/do not know $(21 \%)$.
} 
During the author's field study, the interviewees discussed several issues in regard to public legitimacy of democracy in Turkey. Professor Cengiz Aktar from Bahcesehir University noted that societal and intellectual support for the JDP government against the military's interference in the presidential elections (the April 27, 2007 e-memorandum) was a key dynamic behind the government's clear standing against the intervention. The July 22, 2007 parliamentary elections results, which involved a substantial increase in the JDP's votes (47\%) seems to confirm Aktar's observation. Several interviewees criticized the Turkish people for not having a strong position against the military interventions. As discussed earlier, former diplomat Akin Ozcer argued that the absence of strong anticoup social movements is one of the major problems Turkish democracy. In a similar line, Professor Berdal Aral from Fatih University considered that a considerable size of nationalist-secular-urban masses in the country is supportive of the military interventions. For Aral, this support poses a serious challenge for democratic consolidation. Moreover, Professor Hakan Yilmaz from Bogazici University contended that there is a public consensus on the democratic regime in the country but the protection of basic rights and freedoms faces serious difficulties due to widespread intolerance in all sections of society (the right, the left, the military, and the religious communities, i.e.). Senem Aydin and Muhittin Ataman too cited the low level of tolerance as an important democracy problem. ${ }^{189}$ Furthermore, many interviewees criticized the European Union for the declining levels of public support for EU membership in the recent years. ${ }^{190}$

\footnotetext{
${ }^{189}$ In the 2006 survey study, Carkoglu and Toprak found that 57.1 percent of the respondents agreed with the statement that "As a society, we should not be obliged to put up with views that are totally against the views of the majority" (19.8\% disagree) (p.55).

${ }^{190}$ For example, interviews with Burhan Kuzu, Ahmet Kenan Tanrikulu, and Ziya Muezzinoglu.
} 


\section{Elite Consensus and Anti-System Parties}

In the post-1999 period of EU accession process, Turkey has not faced any politically significant group or political party working for a non-democratic political regime. In a reflection of high level of public legitimacy of the democratic regime, the political landscape has been free from extremist parties. Particularly important, the ideational transformation of political Islamists following the 1997 military intervention has contributed to the democratic consolidation. Despite the lack of anti-system parties, a few significant problems still need to be resolved in regard to elite consensus on the democratic regime. The European integration process has played an important role in strengthening both secularism and democracy in the country.

In contrast to the high level of ideological polarization and political violence of the 1970s, which led to a military coup in 1980, Turkish politics was quite peaceful in the 1990s but the political landscape witnessed the rise of political Islam and Kurdish nationalism (Ozbudun 2000: 74, Sayari 2002: 12-14, Kalaycioglu 2010: 174). Both of them posed serious challenges for the secular and nationalist foundations of Ataturk's Republic. The Islamist challenge targeted the state-centered, strict interpretation of secularism that provided little room for a full enjoyment of religious rights and freedoms, particularly in the public space. The Kurdish nationalists had demands ranging from the recognition of Kurdish identity to the creation of an independent Kurdish state in the South-East (Keyman and Onis 2007: 178).

The 1995 parliamentary elections resulted in the establishment of Welfare Party-

True Path Party (Refahyol) coalition government. The political Islamist Welfare Party (WP) under the leadership of Necmettin Erbakan followed an ambivalent position 
towards the secular regime. In a survey conducted in 1995, 61 percent of the Welfare Party supporters favored an Islamic political order (Ozbudun 2000: 87-93). The European Court of Human Rights upheld the WP's closure (1998) by the Turkish Constitutional Court for violating the principle of secularism in the constitution, although the Court's decision was based on statements made by party officials instead of a party programme (Zurcher et al 2004: 59-60). The WP never called for the foundation of an Islamic state and followed a very pragmatic line while in power, but much of the WP's appeal was based on religious grounds. Whether the WP could be considered an anti-system party is an open question. What is certain is that its appeal to religious grounds and the challenge to 'assertive secularism' of the Turkish state made its closure by the constitutional court easier (due to a low threshold for banning political parties) (Ozbudun 2000: 89-90, Zurcher et al 2004: 55, Kuru 2006: 136-42).

The February 28, 1997 military intervention, which resulted in the end of the WP led coalition government (June 18) and the closure of the party (January 1998) has been consequential for the transformation of political Islam towards a stance for pro-EU, conservative democratic party politics. The intervention and the closure of the WP accelerated divisions among the political Islamists. While the traditionalists continued to follow Erbakan's 'National View' with the foundation of the Felicity Party (Saadet Partisi, founded in July 2001), the R.Tayyip Erdogan-Abdullah Gul led younger generation of reformists established the Justice and Development Party (AK Parti/AKP) in August 2001. ${ }^{191}$ In contrast to the 'National View', which involved ambiguous

\footnotetext{
${ }^{191}$ From the closure of the Welfare Party in January 1998 to the foundation of the FP and the JDP, the political Islamists took place in the Virtue Party (Fazilet Partisi), which was closed down by the Turkish
} 
positions concerning secular democracy, free market economy, and Western foreign policy orientation, the Erdogan-Gul led JDP has explicitly denied that it is a party of Islamists or Muslim democrats; rather, the JDP has claimed for being a 'conservative democratic party' that attributes a major importance to pluralist democracy, human rights, civil society, fundamental rights and freedoms, family, and traditional values (Akdogan 2006: 53-65, Cinar 2006: 473-4, Tezcur 2005: 17, Yavuz 2006: 1-4). ${ }^{192}$

The Justice and Development Party has realized an outstanding electoral performance in the Turkish politics by winning three consecutive elections $(2002,2007$, 2011) that paved the way for single-power majority governments (see Table 5.2). ${ }^{193}$ The JDP governments have achieved better economic performance as compared to the previous era of coalition governments (1991-2002), succeeded to launch the accession negotiations with the European Union (2005), and undertaken democratization and human rights reforms in line with the EU's democratic conditionality. According to a survey taken in May 2006, the majority of the Turkish people considered the JDP government as successful in various areas including the economy $(67 \%)$, relations with

Constitutional Court in June 2001. The VP period witnessed the rise of divisions between the traditionalists and the reformists.

192 'Bize Islamci parti demeyin-Do not call us Islamist Party', Radikal, September 5, 2002. On the National View Movement, see Metiner 2004 and Dagi 2001. The JDP's party programme ('Democracy and Development') is available online at the website of the party: http://eng.akparti.org.tr/english/partyprogramme.html. Yalcin Akdogan, who is the senior advisor to the party chief R.T.Erdogan and the ideologue of the party's political ideology ('conservative democracy') has argued that the JDP is different from the former National View Movement based Islamist parties in terms of organization, political identity, style, and campaign politics. Akdogan has also argued that the JDP's electoral success should not be considered as a success of political Islam although the JDP leadership includes 'ex-Islamists' (Akdogan 2006: 53).

${ }^{193}$ In the first decade of Turkey's multi-party democracy, the Democrat Party (DP) too won three consecutive elections $(1950,1954,1957)$; however, the DP lost its percentage of votes in the 1957 elections while the JDP achieved to increase its votes in each consecutive elections by having $34.3 \%, 46.5 \%, 49.9 \%$ in the 2002, 2007, 2011 elections respectively. 
the EU (66\%), Turkish politics (62\%), and the treatment of religious and secular people in public offices and society ( $60 \%$ and $55 \%$, respectively). The same survey found that people were most satisfied with the JDP's performance concerning the EU membership, improvement of the economy, fight against corruption, solving healthcare issues, and the expansion of religious freedoms.

According to a recent survey (June 2011), the Turkish people have been quite satisfied with the JDP's performance in power since November 2002; while only 4 percent of these surveyed were satisfied with the direction the country was following in 2002 , the level of satisfaction increased to 40 percent in 2006 , and to 48 percent in 2011. ${ }^{194}$ Particularly notable, the 2006 survey provided important evidence for the different levels of perceptions among the Turkish people in regard to the JDP's commitment to democracy ( $53.7 \%$ yes, $25.9 \%$ no) vis-à-vis the Welfare Party's ( $28.6 \%$ yes, $42.4 \%$ no). In addition, 50.8 percent of the respondents agreed with the statement that 'among the existing parties, the JDP is the one that supports fundamental rights and liberties the most' (30.7\% disagree, 15.4 undecided) (Carkoglu and Toprak 2007: 92-94). In contrast to the ideology-based WP, which acquired support mostly from Islamists/religious voters, the JDP has become a catch all party (46.5\% in $2007,49.9 \%$ in 2011) by receiving support not only from religious Turks but also from pro-EU liberal democrats and the Kurdish people (Kalaycioglu 2010: 174, Kardas 2008: 180, Onis 2004: 13-17). Overall, the JDP has followed a different pattern of political identity and

\footnotetext{
194 'On Eve of Elections, a More Upbeat Mood in Turkey', the Pew Research Center (Washington D.C.), June 7, 2011 (http://pewglobal.org/2011/06/07/on-eve-of-elections-a-more-upbeat-mood-in-turkey/). The survey also found that religious people are more satisfied with the country's direction under the JDP vis-àvis the secular part of the Turkish society.
} 
governmental performance vis-à-vis the Islamist Welfare Party, and it does not have any feature of an anti-system party. Therefore, the transformation of political Islam following the February 1997 military intervention has made an important contribution to the consolidation of democracy in Turkey.

Table 5.2: Turkish Parliamentary Election Results (1995-2011): Percentages of votes and number of seats in the Parliament (TBMM)

\begin{tabular}{|l|l|l|l|l|l|}
\hline PARTIES* & $\mathbf{1 9 9 5}$ & $\mathbf{1 9 9 9}$ & $\mathbf{2 0 0 2}$ & $\mathbf{2 0 0 7}$ & $\mathbf{2 0 1 1}$ \\
\hline $\begin{array}{l}\text { Republican People's Party } \\
\text { (CHP) }\end{array}$ & $\begin{array}{l}10.7 \% \\
(49)\end{array}$ & $\begin{array}{l}8.7 \% \\
(0)\end{array}$ & $\begin{array}{l}19.4 \% \\
(177)\end{array}$ & $\begin{array}{l}20.9 \% \\
(112)\end{array}$ & $\begin{array}{l}26 \% \\
(135)\end{array}$ \\
\hline Democratic Left Party (DSP) & $\begin{array}{l}14.6 \% \\
(76)\end{array}$ & $\begin{array}{l}\mathbf{2 2 . 2 \%} \\
\mathbf{( 1 3 6 )}\end{array}$ & $\begin{array}{l}1.2 \% \\
(0)\end{array}$ & - & $\begin{array}{l}0.25 \% \\
(0)\end{array}$ \\
\hline Motherland Party (ANAP) & $\begin{array}{l}19.6 \% \\
(132)\end{array}$ & $\begin{array}{l}13.2 \% \\
(86)\end{array}$ & $\begin{array}{l}5.1 \% \\
(0)\end{array}$ & - & - \\
\hline $\begin{array}{l}\text { True Path Party/Democrat Party } \\
\text { (DYP-DP) }\end{array}$ & $\begin{array}{l}19.2 \% \\
(135)\end{array}$ & $\begin{array}{l}12 \% \\
(85)\end{array}$ & $\begin{array}{l}9.5 \% \\
(0)\end{array}$ & $\begin{array}{l}5.4 \% \\
(0)\end{array}$ & $\begin{array}{l}0.15 \% \\
(0)\end{array}$ \\
\hline Nationalist Action Party (MHP) & $\begin{array}{l}8.1 \% \\
(0)\end{array}$ & $\begin{array}{l}18 \% \\
(129)\end{array}$ & $\begin{array}{l}8.3 \% \\
(0)\end{array}$ & $\begin{array}{l}14.2 \% \\
(71)\end{array}$ & $\begin{array}{l}13 \% \\
(53)\end{array}$ \\
\hline $\begin{array}{l}\text { Justice and Development Party } \\
\text { (AKP) }\end{array}$ & - & - & $\begin{array}{l}\mathbf{3 4 . 3 \%} \\
\mathbf{( 3 6 5 )}\end{array}$ & $\begin{array}{l}\mathbf{4 6 . 5 \%} \\
\mathbf{( 3 4 1 )}\end{array}$ & $\begin{array}{l}\mathbf{4 9 . 8 \%} \\
\mathbf{( 3 2 7})\end{array}$ \\
\hline Virtue Party (FP) & - & $\begin{array}{l}15.4 \% \\
(111)\end{array}$ & - & - & - \\
\hline Felicity Party (SP) & - & - & $2.5 \%(0)$ & $\begin{array}{l}2.3 \% \\
(0)\end{array}$ & $\begin{array}{l}1.2 \% \\
(0)\end{array}$ \\
\hline Welfare Party (RP) & $\mathbf{2 1 . 4 \%}$ & - & - & - & - \\
\hline $\begin{array}{l}\text { HADEP/DEHAP/DTP/BDP** } \\
\text { (Kurdish Nationalist Party) }\end{array}$ & $\begin{array}{l}\mathbf{( 1 5 8 )} \\
(0)\end{array}$ & $\begin{array}{l}4.7 \% \\
(0)\end{array}$ & $\begin{array}{l}6.1 \% \\
(0)\end{array}$ & - & - \\
\hline Others & $1 \%(0)$ & $3 \%(0)$ & $12 \%(0)$ & $5 \%(0)$ & $\begin{array}{l}4.5 \% \\
(0)\end{array}$ \\
\hline Independents & $0.5 \%(0)$ & $0.9 \%(3)$ & $1 \%(8)$ & $\begin{array}{l}5.3 \% \\
(26)^{* *}\end{array}$ & $\begin{array}{l}6.6 \% \\
(35) * *\end{array}$ \\
\hline Total Seats & 550 & 550 & 550 & 550 & 550 \\
\hline Turnout & $82.3 \%$ & $87.1 \%$ & $79.1 \%$ & $84.2 \%$ & $87.4 \%$ \\
\hline
\end{tabular}




\section{Notes:}

* The nationwide electoral threshold for political parties is 10 percent. The centre-left parties: CHP and DSP; the center-right parties: AKP, ANAP, DYP; the political Islamist parties: RP, SP, FP; the Turkish nationalist party: MHP; the Kurdish nationalist parties: HADEP/DEHAPDTP/BDP.

** Members of the Kurdish nationalist party took part in the 2007 and 2011 elections as independent candidates not to be failed by the 10 percent threshold.

Source: Kalaycioglu 2010: 158, the website of Turkey's High Election Board (YSK) (http://www.ysk.gov.tr), and http://www.secimsitesi.com/GenelSecimSonuclari.asp?SY=2007

The lack of an anti-system party in the country should be seen an asset for democratic consolidation, yet two related important issues have continued to pose challenges to elite consensus on the democratic regime. ${ }^{195}$ The first issue is the lack of consensus on how secularism is defined by the key political actors including the political parties, the military, and the judiciary. The question has major repercussions on the functioning of democracy in the country as demonstrated by the military's intervention (the April 27 e-memo) in the last presidential election (2007) and the attempt to close the JDP by the chief public prosecutor in $2008 .{ }^{196}$ Both the military and the judicial attempts against the JDP showed that the party's understanding of secularism was in conflict to a large extent with the one identified by the secular establishment (the military, and upper

\footnotetext{
${ }^{195}$ The EU's annual progress reports on Turkey have never considered the Justice and Development Party as an anti-system party. In addition, the progress reports have confirmed that the party has had a firm commitment to the EU accession process. For example, the 2004 report noted as follow: 'The three-party coalition government which had ruled Turkey since 1999 was, following the early elections in November 2002 , replaced by a one-party government. In the last two years, Turkey has enjoyed greater stability, overcoming the consequences of the two serious financial crises of 2000 and 2001. Political and economic reforms received new impetus because of the determination of the (JDP) government to meet the Copenhagen criteria' (p.20).

${ }^{196}$ Turkey's Constitutional Court decided not to close the JDP but imposed financial penalties in July 2008. In the eleven-member Court, six judges made decision in favor of the closure while five judges rejected the charges. Only one vote saved the JDP as seven votes were enough to ban the party.
} 
echelons of the bureaucracy and the judiciary) and the main opposition party (the Republican People's Party, CHP). For Ergun Ozbudun, a prominent constitutional law professor and an expert on democratic consolidation, a reasonable consensus on the definition of secularism is necessary for the consolidation of Turkish democracy (Ozbudun 2009: 155-166). Although the country has been free from a 'secularistIslamist' divide at the public level, as confirmed by the 2006 survey study ${ }^{197}$, the right and the left sides of the political landscape have not yet reached a reasonable consensus. The second major issue concerning elite consensus is that the military's interference in politics and the coup plots have not yet faced a solid civilian reaction. In this regard, the Republican People's Party's (RPP) conventional alliance with the military for the sake of protecting the secular regime has made it difficult to realize a democratic pattern of civilmilitary relations in the country. The RPP's underestimation of the threat posed by the recent coup plots (the Ergenekon and the Balyoz trials) is a seminal example in this regard. $^{198}$

The European integration process has helped the achievement of elite consensus in several ways. First of all, the transformation of political Islam in the country started

\footnotetext{
197 The May 2006 survey study showed that the majority of the Turkish people has been quite tolerant to both religious and secular lifestyles, and that there is not a divison between the so-called 'secularists' and the 'Islamists'. As suggested earlier, the survey also provided an important evidence for the declining levels of public support for an Islamic political regime (21\% in 1999, 9\% in 2006). The survey asked whether 'secularism is under threat in Turkey'; $72.6 \%$ said no while $22.6 \%$ said yes. In addition, the majority of the respondents considered that female civil servants $(68 \%)$ and university students $(76 \%)$ should be allowed to cover if they wish (Carkoglu and Toprak 2007: 32-33, 76).

${ }^{198}$ The former CHP chief Deniz Baykal made a statement that he could be a lawyer for the Ergenekon defendants. Suheyl Batum, who is currently a vice president of the CHP, stated that 'the whole military is destroyed; we supposed it as the military but it was just a paper tiger' in reference to the Ergenekon trial on the coup allegations. In the June 2011 parliamentary elections, several MP candidates, who have been in jail due to the alleged involvement in the coup plots, get elected in the CHP's list.

'Ergenekon Avukati', Milliyet, July 6, 2008 (http://www.milliyet.com.tr/Default.aspx?aType=YazarDetay\&ArticleID=890324\&AuthorID=68), 'Batum: Asker meger kagittan kaplanmis', February 6, 2011 (http://www.ntvmsnbc.com/id/25179379/)
} 
earlier than the Helsinki decision of Turkey's EU candidacy (1999); however, the EU accession process substantially facilitated the moderation process of the political Islamists that culminated in the emergence of pro-EU/conservative democratic political party (Tezcur 2005: 17, Onis 2004: 14-17, Tepe 2008: 208). In contrast to cultural essentialism and anti-EU positions of the Welfare Party, the JDP realized comprehensive political and economic reforms to fulfill the Copenhagen criteria, succeeded in launching accession negotiations with the EU. To an important extent, the JDP's political mission to transform the Kemalist paradigm in favor of a more liberal pattern of state-society relations, basic rights and freedoms, and the practice of secularism has converged with the Copenhagen criteria driven democratization and human rights reforms (Cinar 2006: 480-82, Dagi 2006: 102). In doing so, the JDP has also been transformed into a more moderate political party integrating further with the secular democratic regime. In addition, the EU's requirement for the civilian control of the military has generated an important incentive for the JDP's commitment to the EU accession process (Jenkins 2006: 186).

Second, the European integration process safeguarded secularism in the country even though the EU has not offered a concrete model concerning the domestic controversies on the practice of secularism (the headscarf issue, i.e.) (Onis 2004: 17; 2009: 12). Moreover, the expansion of fundamental freedoms, including the freedom of religion, during the EU accession process has helped moving the Turkish secularism into a more liberal pattern. ${ }^{199}$

\footnotetext{
${ }^{199}$ In the aftermath of the EU conditionality driven political reforms, public reactions to strict secularist policies have declined to a great extent. According to the May 2006 survey, the percentage of respondents
} 
Finally, the European integration process has provided a favorable environment for the increasing civilian consensus on the democratic control of the armed forces. The EU's conditionality in the realm of the civil-military relations and its explicit support for the trials on the coup allegations strengthened the civilians against the military's interference in politics. In addition, the Socialist members of the European Parliament have often criticized the Republic People's Party in favor of the democratic civil-military relations. For example, the RPP's position in the 2007 e-memorandum and its underestimation of the coup allegations were condemned by the European Socialists. ${ }^{200}$ When the author asked about the major problems of Turkish democracy in his field work, none of the interviewees referred to the existence of an anti-system party in the country. Hakan Yilmaz and Ersin Kalaycioglu, Bogazici and Sabanci University political scientists, argued that democracy as a political regime has an overwhelming public support; however, polarization and the lack of trust among political parties and major groups pose serious problems. Professors Kalaycioglu and Ziya Onis noted that secularism is still an area of considerable tension in the country. Muhittin Ataman criticized the state control over religion while Ali Resul Usul considered that the consolidation of Turkish democracy requires overcoming authoritarian understandings and practices of secularism. Former diplomat Akin Ozcer and social democratic MP Ufuk

who indicate that religious people are subject to state repression declined from $43 \%$ in 1999 to $17 \%$ in 2006 (Carkoglu and Toprak 2007: 13).

\footnotetext{
${ }^{200}$ The RPP's inclusion of the Ergenekon defendants as MP candidates in the 2011 elections was criticized by the Vice-President of the Socialist Group in the European Parliament. Swoboda: 'CHP, sivil anayasaya destek vermeli', June 17, 2011 (http://www.euractiv.com.tr/ab-ve-turkiye/interview/swoboda-chp-sivilanayasaya-destek-vermeli-019084). On the Socialists'criticism of the RPP in regard to the 2007 presidential elections crisis/the April 27 e-memo, see: 'Avrupalı Sosyalistler'in CHP'ye tepkisi dinmiyor', Yeni Safak, May 4, 2007 (http://yenisafak.com.tr/Gundem/?t=04.05.2007\&i=43758)
} 
Uras criticised the RPP for underestimating the coup allegations/the Ergenekon trial. In addition, Professor Berdal Aral questioned the RPP's commitment to democracy due to the fact that an important part of the RPP-minded middle class is supportive of military coups. In contrast, several interviewees noted that the Ergenekon trial should be subject to criticisms as the trial process has many ambiguities, inconsistencies, and violations of fair trial. ${ }^{201}$ Finally, an overwhelming majority of the interviewees argued that the lack of intra-party democracy, the party leaders' dominance in shaping the MP lists, and the political parties law are serious democracy problems in the country. ${ }^{202}$

\section{Stateness}

Turkey's decades-long armed conflict with the Kurdish separatist organization (PKK, Partiya Karkeren Kurdistan-Kurdish Workers' Party) in particular, and the Kurdish question in general have posed a serious challenge for the consolidation of democracy in the country. In contrast to the 1984-1999 period in which 35-40 thousand people lost their life in the war between the PKK and the Turkish state, the amount of violence has declined significantly in the aftermath of the capture of the PKK leader Abdullah Ocalan in February 1999. In addition, the post-1999 period has witnessed the success of the Kurdish ethnic party in the municipal and parliamentary elections. ${ }^{203}$ The

\footnotetext{
${ }^{201}$ Interviews with Senem Aydin, Ersin Kalaycioglu, Huseyin Pazarci, and the anonymous law professor from Yeditepe University. The author did not ask the Ergenekon issue specifically; rather, these interviewees discussed it while they were responding to the twelve questions in the interview document (Appendix 1).

202 Interviews with Ziya Muezzinoglu, Senem Aydin, Yilmaz Ensaroglu, Huseyin Pazarci, Seyfi Tashan, Ali Resul Usul, and anonymous law professor from Yeditepe University.

${ }^{203}$ See Table 5.2 for the performance of the Kurdish ethnic parties in the 1999, 2002, 2007, and 2011 parliamentary elections. In the 2009 local elections, the Kurdish ethnic party (DTP) won the governance of ninety-six municipalities along with the metropolitan city of Diyarbakir. In the 2004 municipal elections,
} 
Copenhagen political criteria-related democratization and human rights reforms in the past decade have involved several improvements concerning the cultural and language rights of the Kurdish people. Although these reforms have been very helpful, the consolidation of democracy in Turkey requires taking further steps in order to handle the Kurdish question.

The genesis of the Kurdish question goes back to the late Ottoman and the early Republican periods. During the one-party rule (1923-50), the Turkish state forcefully repressed the Kurdish rebellions, and did not recognise the Kurdish identity. The nationalist ideology of the Republican regime envisioned an organic and homogenous society by providing no room for the expression of non-Turkish ethnic identities (Keyman and Onis 2007: 294, Karakas 2009: 49-53). The decades-long question experienced an important transformation with the establishment of the Marxist-Leninist Kurdish separatist PKK in the early 1970s. The PKK's attempt to form an independent Kurdish state paved the way for a violent armed conflict with the Turkish state, particularly in the period of 1984-99. The conflict resulted in the death of about 25-40 thousand Kurdish guerillas, five thousand Turkish soldiers, and 5-10 thousand civilians (Eccarius-Kelly 2011: 46-48).

From 1923 until the late 1990s, the Kurdish problem in the country was taken predominantly as a security problem, and the military-driven state policies denied the Kurdish identity. For example, the use of Kurdish language was prohibited from 1983 to 1991, and the Kurdish population has only recently enjoyed cultural rights such as radio/TV broadcasting in their native languages. The internationalization of the Kurdish achieved to rule several municipalities including the major Southeastern city, Diyarbakir. 
issue after the Gulf War (1990-91), the mounting levels of PKK insurgency in the early 1990s, and the increasing U.S. and European criticisms of Turkey concerning violations of humans rights stemming from the armed conflict with the PKK made the Kurdish question a central problem for Turkey's democracy in the 1990s (Kalaycioglu 2010: 161, Turan 2007: 337-8, Ahmad 2008: 200-4).

The capture of PKK leader Abdullah Ocalan in February 1999, the Helsinki decision of Turkey's candidacy for EU membership in December 1999, the fast-tract democratization and human rights reforms to fulfill the Copenhagen political criteria (2001-2004), and the increasing power of the civilian authority vis-à-vis the military throughout the 2000s have made the resolution of the Kurdish question more likely in the past decade. In contrast to the security identification of the question in which the military played a central role in the previous two decades, the 2000s witnessed several positive developments in this area: (i) the declining level of violence between the PKK and the Turkish state following Ocalan's capture, (ii) the expansion of fundamental rights and liberties as well as cultural rights for the Kurdish population during the EU accession process, (iii) the Turkish government's initiative ('democratic opening', launched in fall 2009) to find a political solution to the Kurdish question ${ }^{204}$, (iv) the presence of a Kurdish ethnic party in the parliament following the 2007 and the 2011 elections, and (v) the

\footnotetext{
${ }^{204}$ On the 'democratic opening' see: Milli Birlik ve Kardeslik Projesi: Demokratik Acilim-The National Unity and Brotherhood Project: The Democratic Opening, Public Relations Office of the Justice and Development Party. (http://www.akparti.org.tr/media/halklailiskiler/M\%C4\%B0LL\%C4\%B0\%20B\%C4\%B0RL\%C4\%B0K\%2 0ve\%20KARDE $\%$ C5\%9EL\%C4\%B0Kyeni.pdf)
} 
ongoing negotiations between the PKK authorities (including the imprisoned Ocalan) and the Turkish state ${ }^{205}$.

While the recognition of Kurdish identity and the attempt to find a political solution were almost a taboo until the turn of the century, now both the people and the political elite, including the military, have become more willing to end the decades-long armed conflict through a political solution ${ }^{206}$. In addition, the PKK's focus has shifted from establishing a Kurdish state to the following targets: the constitutional recognition of Kurdish identity, the expansion of social, cultural, and political rights of the Kurdish people, and the formation of an autonomous Kurdish entity in the South-east ${ }^{207}$ (Karakas 2009: 17-50, Eccarius-Kelly 2011: 4-12).

The European integration process has helped Turkey to resolve the Kurdish question in several areas, but has not played a decisive role. It resulted in the expansion of fundamental rights and liberties, declining levels of torture and other human rights

${ }^{205}$ On the seven-part series of negotiations between the PKK and the Turkish state, see Candar 2011: 4056 .

${ }^{206}$ According to a poll taken by SETA-Pollmark in August 2009 (10,577 respondents in 601 urban and rural areas took part), the people considers the Kurdish question a political problem in contrast to the security oriented conceptions of the 1980s and 1990s. $71.1 \%$ respondents considered that 'the policies implemented in the last 25 years against terrorism' not successful, while only 20.8 percent found them successful ( $75 \%$ versus $14.8 \%$ for Kurds, $70.4 \%$ versus $21.9 \%$ for Turks). On the other hand, both the Turkish and Kurdish people regarded the parliament, the government, the president, and the political parties as the major actors to settle the Kurdish question. However, the Kurdish people did not consider the Turkish military a key actor in this process while the Turkish people allocated a major role to the military. For the question that "in your opinion, which of the below will be the most effective in the process of settlement of the Kurdish question", the top three actors for Turks are the military (43.8\%), the parliament (39.4\%), and the government (38.4\%) while Kurds considered the parliament (50.7\%), the government (45.4\%), and the presidency (28.3\%). Public Perception of the Kurdish Question in Turkey, p.7-8 (It is available online at: http://www.setadc.org/pdfs/Public_Perception_of the_Kurdish_Question_in_Turkey.pdf)

207 On the changing targets of the PKK, see the interview with Murat Karayilan (the acting commander): "Karayilan: PKK artik eski PKK degil", Milliyet, May 5, 2009. (http://siyaset.milliyet.com.tr/karayilan-pkk-artik-eski-pkk-degil/hasan-cemal/siyaset/siyasetyazardetay/06.05.2009/1091211/default.htm) 
violations, and the abolition of the death penalty (the imprisoned PKK leader was sentenced for). Particularly important, the explicit Copenhagen conditionality paved the way for increasing cultural rights for the Kurdish people. ${ }^{208}$ In addition, the EU accession process has played an important role in expanding the scope of public debate on formerly taboo issues including the Kurdish question. The two constitutional amendments and the eight EU harmonization law packages in the period of 2001-2004 were most consequential as these legislative changes were made to fulfill the Copenhagen criteria in order to start the EU accession negotiations.

The stalemate in the Turkey-EU relations (after 2005) has also weakened the leverage of the European integration process on Turkey's efforts to handle the Kurdish question. The JDP government's Kurdish initiative, launched in 2009, was primarily driven by domestic dynamics although the European Union encouraged the government for this effort. The EU called the Kurdish ethnic party (DTP/BDP) to distance itself from the PKK while recognizing the latter as a terrorist organization. ${ }^{209}$ In addition, the EU encouraged the Turkish government and political parties to reach a political solution for the Kurdish question. Furthermore, the EU, through the Commission's annual progress reports, has monitored Turkey's performance in the legislative changes and the level of implementation in regard to cultural rights of the people with Kurdish origin.

\footnotetext{
${ }^{208}$ In 1999, the State Security Courts opened an investigation for the former Minister of Foreign Affairs since he argued that the Kurdish broadcasting should be possible (Karakas 2009: 19). Later (in 2008), the Kurdish broadcasting in radios/TVs was legalised due to the EU conditionality to such extent that the Turkish state channel started to make 24 hours broadcasting in several non-Turkish languages including Kurdish. In addition, the Kurdish broadcasting was legalised in private channels.

${ }^{209}$ The European Parliament's annual reports on Turkey, 2007-2011. For example see the 2007 report, page 5. It is available online at: $\mathrm{http} / / \mathrm{www}$.europarl.europa.eu/sides/getDoc.do?pubRef=//EP//NONSGML+REPORT+A6-2008-0168+0+DOC+PDF+V0//EN
} 
In spite of these positive effects, the EU's leverage on Turkey to make further reforms concerning the Kurdish question remained very limited in the years after 2005 vis-à-vis the 2001-2004 period. For example, the EU has asked for the elimination of restrictions concerning Kurdish education and the use of Kurdish language in political life (2007 to 2011 regular reports) as well as the ratification of the Council of Europe's Framework Convention for the Protection of National minorities-FCPNM (2001 to 2011 regular reports). In spite of the EU's demands, Turkey has not yet made any progress in these areas. In the absence of a credible EU commitment to Turkey's prospect of membership, the EU has lacked the capacity to drive Turkey to follow a fast-track pattern of reforms in this area. Certainly, domestic political crises in the country in 2007 and 2008 along with the sporadic occurrence of PKK violence also complicated the resolution of the Kurdish question.

The interviews with Turkish politicians and academicians provided several insights as regards the impact of European integration process for the Kurdish question. Professor Ziya Onis suggested that Turkey could handle the question more easily if the Turkey-EU relations stay alive. He also argued that the deadlock in the Turkey-EU relations after 2005 has played an important role for the low level of success in the government's Kurdish initiative. In a similar line, Professor Ali Karaosmanoglu argued that the Kurdish initiative has been undertaken without any considerable impact from the EU. Ege Erkocak from the Secretariat of European Affairs confirmed the EU's positive role in the 2001-04 reforms. He also argued that the EU accession process has helped the expansion of public debate on the formerly taboo issues. Particularly interesting, he provided an anecdote that a bureaucratic commission, which he involved, spent about 
eight and a half hours to decide on the title of an EU directed law concerning the right of broadcasting in non-Turkish languages (in 2002). Keeping in mind that the use of the 'Kurdish question' has only recently been widely used in the country, Erkocak's anecdote suggests that the EU accession process has been entangled with very sensitive issues in the political landscape.

For Professor Cengiz Aktar, the European integration process has helped Turkey to reflect upon the strict nationalist policies pursued in the past century dating back to the 1908 CUP coup in the Ottoman period. Moreover, several interviewees discussed about the limits and negative effects of the EU accession process. The JDP Member of Parliament Murat Mercan suggested that a uniform model from the EU member states does not exist to guide Turkey's efforts to handle the Kurdish question as he noted the variance across the Spanish, Nordic and French models. Yilmaz Ensaroglu, who is a human rights expert in a think tank, pointed out the different conceptions of minorities between Turkey and the EU. Particularly interesting, he argued that Turkey's religious and ethnic minorities (the Alevi sect of Islam and the Kurds) have not been happy with the EU's treatment of themselves as minorities since they considered that treatment as inferiority. Professor Ali Resul Usul contended that the rise of ethnic issues in the EU accession process could generate both positive and negative consequences. Usul was concerned that the division of 'demos' with the EU directed ethnic debates could complicate the democratic consolidation. With an increasing negative note, Huseyin Pazarci (the Member of Parliament) and Seyfi Tashan (the president of a think tank) criticized the EU as they considered that the EU's involvement in the Kurdish question results in political instability in the country. 
Table 5.3 provides a summary of the domestic and European dynamics of

Turkey's democratic consolidation by component.

Table 5.3: European versus Domestic Dynamics of the Consolidation

\begin{tabular}{|c|c|c|c|}
\hline $\begin{array}{l}\text { Components } \\
\text { of Democratic } \\
\text { Consolidation }\end{array}$ & $\begin{array}{l}\text { Major Events- } \\
\text { Key Developments }\end{array}$ & Domestic Dynamics & European Dynamics \\
\hline $\begin{array}{l}\text { 1. Free, fair, } \\
\text { and } \\
\text { competitive } \\
\text { elections }\end{array}$ & $\begin{array}{l}\text {-Holding parliamentary, } \\
\text { presidential, and local } \\
\text { elections without any } \\
\text { considerable problem } \\
\text { since } 1950 \text { with the } \\
\text { exception of semi- } \\
\text { competitive } 1983 \\
\text { elections. }\end{array}$ & $\begin{array}{l}\text {-High level of public } \\
\text { and elite consensus } \\
\text { about the legitimacy of } \\
\text { the democratic } \\
\text { elections in the country. }\end{array}$ & $\begin{array}{l}\text {-The EU suggests that } \\
10 \% \text { electoral threshold } \\
\text { is too high while the } \\
\text { ECHR ruled (2007) that } \\
\text { it is up to the countries. } \\
\text {-The EU's democratic } \\
\text { conditionality (the } \\
\text { Copenhagen political } \\
\text { criteria) anchored the } \\
\text { maintenance of } \\
\text { democratic elections. }\end{array}$ \\
\hline $\begin{array}{l}\text { 2. Protection } \\
\text { of basic } \\
\text { rights and } \\
\text { liberties, } \\
\text { human and } \\
\text { minority } \\
\text { rights }\end{array}$ & $\begin{array}{l}\text {-The } 1982 \text { constitution } \\
\text { prioritized the state over } \\
\text { the full enjoyment of } \\
\text { fundamental rights and } \\
\text { liberties. } \\
\text {-The } 2001,2004 \text {, and } \\
2010 \text { constitutional } \\
\text { amendments expanded } \\
\text { the scope of } \\
\text { fundamental rights and } \\
\text { liberties. }\end{array}$ & $\begin{array}{l}\text { - The state of } \\
\text { emergency in the } \\
\text { South-east (1987-2002) } \\
\text { resulted in further } \\
\text { restrictions of already } \\
\text { limited scope of } \\
\text { fundamenral rights and } \\
\text { liberties. } \\
\text { - The JDP single-power } \\
\text { majority government } \\
\text { (2002-2007) enhanced } \\
\text { the momentum of EU } \\
\text { related reforms vis-à- } \\
\text { vis the 1999-2002 } \\
\text { coalition government. }\end{array}$ & $\begin{array}{l}\text { - The } 1999 \text { Helsinki } \\
\text { decision of Turkey's EU } \\
\text { candidacy and the } \\
\text { Copenhagen } \\
\text { conditionality rules } \\
\text { paved the way for the } \\
\text { unprecedented political } \\
\text { reforms in 2001-04. } \\
\text {-The EU set the } \\
\text { ratification of } \\
\text { international covenants } \\
\text { on human and minority } \\
\text { rights as a part of the EU } \\
\text { acquis. }\end{array}$ \\
\hline
\end{tabular}




\begin{tabular}{|c|c|c|c|}
\hline & $\begin{array}{l}\text {-The } 2004 \text { constitutional } \\
\text { amendment to Article } 90 \\
\text { made international } \\
\text { human rights agreements } \\
\text { Turkey ratified superior } \\
\text { to domestic laws. }\end{array}$ & & $\begin{array}{l}\text { - Death penalty } \\
\text { abolished (August 2002) } \\
\text { to align with the EU } \\
\text { acquis. } \\
\text { - The Commission } \\
\text { reports (1998-present) } \\
\text { monitor Turkey's } \\
\text { performance in this area. } \\
\text { - The stalemate in the } \\
\text { Turkey-EU relations } \\
\text { (2005 to present) has } \\
\text { lessened the EU's } \\
\text { leverage. } \\
\text {-The Council of Europe } \\
\text { membership and the } \\
\text { adoption of the ECHR } \\
\text { (1949, 1954). Since } \\
\text { 1987, the Turkish } \\
\text { citizens have been } \\
\text { allowed to apply to the } \\
\text { ECtHR. }\end{array}$ \\
\hline $\begin{array}{l}\text { 3.High } \\
\text { prospects of } \\
\text { regime } \\
\text { survival and } \\
\text { civilian } \\
\text { control of } \\
\text { the military }\end{array}$ & $\begin{array}{l}\text { - The military has long } \\
\text { served as a 'guardian'of } \\
\text { the Republic; the } 1960 \\
\text { and } 1980 \text { military coup } \\
\text { d'etats; the } 1997 \text { and } \\
2007 \text { military } \\
\text { memorandums. } \\
\text {-The currently } 1982 \\
\text { constitution extended } \\
\text { further the institutional } \\
\text { and political autonomy } \\
\text { of the military. } \\
\text { - The April } 2007 \text { e- } \\
\text { memorandum by the } \\
\text { General Staff in regard } \\
\text { to the presidential } \\
\text { elections }\end{array}$ & $\begin{array}{l}\text { - Public reaction to the } \\
\text { April } 2007 \text { e- } \\
\text { memorandum; the } \\
\text { governing JDP received } \\
\text { the historic } 47 \% \text { of the } \\
\text { votes in the July } 2007 \\
\text { elections. } \\
\text {-The } 2010 \\
\text { constitutional } \\
\text { amendment made } \\
\text { possible the trial of } \\
\text { coup plots by the } \\
\text { civilian courts. }\end{array}$ & $\begin{array}{l}\text { - The EU monitors } \\
\text { Turkey (1998-present) in } \\
\text { regard to the civil- } \\
\text { military relations. } \\
\text { - The National Security } \\
\text { Council reforms (2001- } \\
\text { 2004) undertaken to } \\
\text { fulfill the Copenhagen } \\
\text { political criteria. } \\
\text { - The stalemate in the } \\
\text { Turkey-EU relations } \\
\text { (2005 to present) has } \\
\text { lessened the EU's } \\
\text { leverage. } \\
\text {-The EU supports the } \\
\text { Ergenekon and Balyoz } \\
\text { trials of coups plots by } \\
\text { the civilian courts. }\end{array}$ \\
\hline
\end{tabular}




\begin{tabular}{|c|c|c|c|}
\hline & $\begin{array}{l}\text {-The } 2003-2004 \text { and } \\
2009 \text { coup plots are } \\
\text { currently under } \\
\text { investigation by the } \\
\text { civilian courts (the } \\
\text { Ergenekon and Balyoz } \\
\text { trials) }\end{array}$ & & $\begin{array}{l}\text {-Turkey's membership } \\
\text { in the NATO (1952); } \\
\text { ambiguous effects on the } \\
\text { civil-military relations. }\end{array}$ \\
\hline $\begin{array}{l}4.1 \\
\text { Legitimacy }\end{array}$ & $\begin{array}{l}\text {-High levels of turnout } \\
\text { in the parliamentary } \\
\text { elections (1950 to } \\
\text { present). }\end{array}$ & $\begin{array}{l}\text {-The level of public } \\
\text { support for an Islamic } \\
\text { political regime } \\
\text { declined from } 27 \% \text { in } \\
1996 \text { to } 9 \% \text { in } 2006 . \\
-77 \% \text { of the people } \\
\text { consider democracy the } \\
\text { best political regime } \\
\text { (the } 2006 \text { poll). } \\
\text {-A considerable part of } \\
\text { the people (27\%) } \\
\text { consider that a military } \\
\text { regime can be more } \\
\text { effective in solving the } \\
\text { country's problems } \\
\text { than elected } \\
\text { governments; the } \\
\text { majority of the people } \\
\text { also agree (56.8\% yes, } \\
18.4 \% \text { no) that the } \\
\text { military occasionally } \\
\text { can criticize the civilian } \\
\text { government (the } 2006 \\
\text { poll). }\end{array}$ & $\begin{array}{l}\text {-The people perceive the } \\
\text { EU symbolizing } \\
\text { modernization, } \\
\text { democracy, respect for } \\
\text { human rights and peace. } \\
\text {-The public considers } \\
\text { the EU membership less } \\
\text { 'as a good thing' in } 2010 \\
(42 \%) \text { than in } 2004 \\
(71 \%) \text {. } \\
\text {-The majority of the } \\
\text { people aspire the EU } \\
\text { membership ( } 69 \% \text { yes, } \\
26 \% \text { no in May } 2011 \\
\text { poll) }\end{array}$ \\
\hline $\begin{array}{l}\text { 4.2 Anti- } \\
\text { System } \\
\text { Parties/Elite } \\
\text { Consensus }\end{array}$ & & $\begin{array}{l}\text { - Ideational change in } \\
\text { Turkey's political } \\
\text { Islamists following the } \\
1997 \text { military } \\
\text { intervention; from an } \\
\text { ideological/religious } \\
\text { party towards a } \\
\text { conservative } \\
\text { democratic catch-all } \\
\text { party. }\end{array}$ & $\begin{array}{l}\text { - In contrast to the EU } \\
\text { skeptical Welfare Party, } \\
\text { the JDP has had a high } \\
\text { commitment to the EU } \\
\text { membership goal. }\end{array}$ \\
\hline
\end{tabular}




\begin{tabular}{|c|c|c|}
\hline & $\begin{array}{l}\text {-Lack of elite } \\
\text { consensus on the } \\
\text { practice of secularism; } \\
\text { secularism is still a } \\
\text { source of a major } \\
\text { political contention. } \\
\text {-Lack of a strong } \\
\text { civilian consensus } \\
\text { against the military } \\
\text { interventions; the main } \\
\text { opposition party (CHP) } \\
\text { follows an ambiguous } \\
\text { position towards the } \\
\text { military's } \\
\text { interventions/coup } \\
\text { plots. }\end{array}$ & $\begin{array}{l}\text { - The JDP's drive to } \\
\text { liberalize the Kemalist } \\
\text { political regime has } \\
\text { converged to a great } \\
\text { extent the EU accession } \\
\text { related political reforms. } \\
\text {-The European } \\
\text { integration process } \\
\text { anchors the secular } \\
\text { regime but also } \\
\text { transforms it by } \\
\text { enhancing the scope of } \\
\text { freedom of religion. }\end{array}$ \\
\hline 4.3.Stateness & $\begin{array}{l}\text {-In contrast to the } \\
\text { military-security driven } \\
\text { paradigm of the } 1980 \mathrm{~s} \\
\text { and the } 1990 \mathrm{~s}, \mathrm{a} \\
\text { political solution to the } \\
\text { Kurdish question has } \\
\text { been more likely in the } \\
\text { past decade. } \\
\text { - The capture of PKK's } \\
\text { leader (A.Ocalan) in } \\
\text { 1999 eased the PKK- } \\
\text { Turkey armed conflict, } \\
\text { and made the political } \\
\text { solution of the Kurdish } \\
\text { question more likely. } \\
\text {-The ongoing } \\
\text { negotiations between } \\
\text { the PKK and the } \\
\text { Turkish state. }\end{array}$ & $\begin{array}{l}\text { - The EU monitors } \\
\text { Turkey (1998-present) in } \\
\text { regard to minority rights. } \\
\text {-The Copenhagen } \\
\text { political criteria related } \\
\text { reforms (2002-04) have } \\
\text { enhanced cultural rights } \\
\text { of the Kurdish people } \\
\text { (tv/radio broadcasting, } \\
\text { i.e.) } \\
\text {-The EU accession } \\
\text { process has helped the } \\
\text { expansion of public } \\
\text { debate on sensitive } \\
\text { issues including the } \\
\text { Kurdish question. } \\
\text {-The EU's conditionality } \\
\text { requires the adoption of } \\
\text { international } \\
\text { conventions on minority } \\
\text { rights as a part of the } \\
\text { acquis. }\end{array}$ \\
\hline
\end{tabular}




\begin{tabular}{|l|l|l|}
\hline & $\begin{array}{l}\text {-The Kurdish ethnic } \\
\text { party (DTP/BDP) takes } \\
\text { part in the the } \\
\text { parliament since the } \\
\text { July 2007 elections; it } \\
\text { also governs several } \\
\text { municipalities } \\
\text { including the South- } \\
\text { Eastern metropolitian } \\
\text { city of Diyarbakir. }\end{array}$ & $\begin{array}{l}\text {-The Kurdish people and } \\
\text { the ethnic party provide } \\
\text { a high level of support } \\
\text { for the EU membership. } \\
\text { - The stalemate in the } \\
\text { Turkey-EU relations } \\
\text { (2005 to present) has } \\
\text { lessened the EU's } \\
\text { leverage. }\end{array}$ \\
& $\begin{array}{l}\text { Kas launched the } \\
\text { Kurdish initiative but it } \\
\text { has not realized any } \\
\text { considerable progress. }\end{array}$ & $\begin{array}{l}\text {-The Council of } \\
\text { Europe/ECtHR helps in } \\
\text { regard to minority rights. }\end{array}$ \\
\hline
\end{tabular}

\section{Conclusion}

The six-decade long but interrupted Turkish democracy has only recently found an opportunity to be consolidated. The current trial process on several military coup plots by the civilian courts, first time in history, represents a symbolic milestone in the changing nature of civil-military relations in the country. The Kurdish question as one of the central challenges for the consolidation has also been widely considered as a political problem recently in contrast to the earlier military-security paradigm that left little room for the recognition of Kurdish identity. Moreover, Turkey has achieved to make a major progress in regard to the protection of fundamental rights and liberties in the past decade. Nevertheless, Turkey has to take further steps to realize democratic consolidation as defined in this study. In this regard, two areas are of fundamental importance: the democratic control of the armed forces and the resolution of the Kurdish question. 
The European integration process, which was launched through the December 1999 Helsinki European Council decision of Turkey’s candidacy, has made several contributions to the consolidation of Turkish democracy. The EU's democratizing impact was most decisive in the period of 2001-2004, in which Turkey realized democratization and human rights reforms at an unprecedented scale in order to fulfill the Copenhagen political criteria and launch the accession negotiations. The two constitutional amendments and the eight EU harmonization law packages involved several changes concerning various components of the consolidation. The legal changes along with improvement in the level of implementation resulted in major progress, particularly on the second and third components: the protection of fundamental rights and liberties including human and minority rights, and the civilian control of the military.

The stalemate in the Turkey-EU relations, the partial suspension of the accession negotiations, and the declining prospect for EU membership have reduced the EU's democratizing leverage in the period 2005-present. Although the EU has continued to monitor Turkey concerning the Copenhagen political criteria, and urged for making further progress in the deficient areas through the annual progress reports, the EU has lost its leverage to great extent in this period. Unless the Turkey-EU relations got a new momentum through a credible prospect for membership, the EU is not expected to play a decisive role for the consolidation of Turkish democracy in the years to come. The course of democratic consolidation could take a longer time in the absence of a dynamic pattern of Turkey-EU relations. 


\section{CHAPTER VI}

\section{COMPARATIVE CONCLUSIONS}

The central research question in this dissertation is: when, under what conditions, and to what extent did European integration, particularly the European Union's requirement for democratic conditionality, contribute to democratic consolidation in Spain, Poland, and Turkey? On the basis of a four-part definition of democratic consolidation, the case study chapters analyzed the democratizing impact of European integration on each component. That impact was also examined in the context of domestic and non-EU international dynamics. While the chapters briefly discussed the period of democratic transition, the major focus was on the process of democratic consolidation by assessing the EU's democratizing effects in three specific time frames: 1977-1986 for Spain, 1994-2004 for Poland, and 1999-present for Turkey.

This chapter will first overview the three case studies and generate comparative observations. Then, it will revisit the two hypotheses, which were set at the beginning of the study. Next, domestic and non-EU international dynamics of democratic consolidation in the three countries will be evaluated vis-à-vis the EU's democratizing role. Finally, the chapter will end with a discussion on implications of the dissertation for future research.

\section{Summary of Findings and Cross-National Observations}

In the post-Franco period of political transformation, the European integration process was an integral part of the process of democratic consolidation in Spain. European political parties and transnational party networks provided organizational, 
material and moral support to both the Spanish left and the Spanish right. The Council of Europe set the holding of free, fair and competitive elections as a precondition for the membership. The European Community explicitly stated that 'respect for and maintenance of representative democracy and human rights' are essential elements of the EC membership (the Copenhagen Declaration, April 1978). Following the enactment of the 1978 constitution, the European Commission provided its favorable opinion for the beginning of accession negotiations as it considered that Spain fulfilled the political conditionality. King Juan Carlos and Prime Minister Felipe Gonzalez (1982-96) underlined many times the critical link between the processes of European integration and democratic consolidation. For the majority of the Spanish people, and particularly for the Spanish left, the EC membership symbolized the end of political isolation from European democracies, which was one of the key features of the Franco period (193975). The European integration process, which received an overwhelming support from the Spanish people and political elite, was very helpful for the acceleration of the consolidation process. Nevertheless, three major qualifications should be made in assessing the EC's democratizing role: (i) domestic dynamics of the consolidation were of primary importance, (ii) the EC did not yet have a rigid mechanism insisting on democratic conditionality ${ }^{210}$, and (iii) the February 23, 1981 coup attempt showed that the EC was not in a position to prevent a serious risk of breakdown of democracy.

While the European Community followed a cautious line in the wake of the postCommunist democratic transition (1989-91), the EC attained an increasing leverage on Poland's political and economic reforms in the aftermath of the June 1993 Copenhagen

${ }^{210}$ In contrast, the 1993 Copenhagen political criteria involved specific rules on human rights, minority rights, and civil-military relations. 
European Council summit. By linking Poland's prospect for membership to fulfillment of the Copenhagen criteria, the European integration process played accelerating and reinforcing roles in the process of democratic consolidation. However, the EU's democratizing role varied across different components of the consolidation. The EC's democratic conditionality anchored the maintenance of democratic elections, contributed to the protection of minority rights and the ratification of international human rights conventions, played a direct role in the abolition of death penalty, and indirectly contributed to public legitimacy of Poland's democracy. In addition, the European integration became an integral part in the broad consensus between Solidarity and the communist successor political parties concerning the major political and economic reforms. The EU's role on civil-military relations remained limited as compared to the one that NATO accession talks (September-November 1997) had for Poland's reforms in the army. As a result, civilian control of the army was not a problem area during the EU accession talks (1998-2002). Moreover, one should acknowledge that Poland's domestic dynamics (the enactment of 1997 constitution and the broad consensus between the right and the left, i.e.) played significant roles for the second and third component of consolidation.

From the 1963 Turkey-EU Associate Agreement to the 1999 Helsinki decision of Turkey's official candidacy for membership, the European Union did not make a considerable impact on Turkey's democracy for two major reasons: (i) the lack of credible prospect for EU membership, and (ii) political instability in Turkey's political landscape that involved the 1971, 1980, and 1997 military interventions. In contrast, the 1999-2004 period witnessed a substantial EU leverage on Turkey’s political reforms 
through the Copenhagen political criteria, set as a prerequisite to launch the accession negotiations. Two constitutional amendments and eight EU harmonization law packages adopted during this period resulted in significant progress in the democratic consolidation, particularly with regard to protection of fundamental rights and liberties, human rights, minority rights, and civilian control of the military. Later, partial suspension of the accession negotiations, which lessened Turkey's prospect for membership, weakened the EU's democratizing impact. As a result, the 1999-2004 period represented a particular era in about half a century of Turkey-EU relations in terms of the EU's leverage on the promotion of Turkey's democracy.

When studying the impact of the European integration process on democratic consolidation in the three countries, several comparative observations can be made. First of all, Spain and Poland shared three major similarities that have been largely absent in the Turkish case: (i) the existence of a credible prospect for membership throughout the EU accession process (Turkey did have that prospect only for the period of 1999-2004), (ii) the European integration process converged with the major era of political transformation (post-Franco and post-Communist periods of regime change), and (iii) the NATO accession process was more helpful than the EU accession process in regard to civilian control of the military. The first two similarities were favorable dynamics for the increasing leverage of the EU accession process in Spain and Poland while Turkey has lacked such advantages. In addition, NATO membership (since 1952) did not save Turkey from the frequent military interventions $(1960,1971,1980$, and 1997) while the 
EU's Copenhagen conditionality was a driving force behind significant reforms in the civil-military relations made in the years $2001-04 .^{211}$

The changing nature of EU's democratic conditionality over time was visible in the latter cases of Poland and Turkey while Spain did not face meticulous conditionality rules as set through the Copenhagen political criteria (1993). Although Spain's membership too was linked to the maintenance of democratic regime and respect for human rights (the 1978 Copenhagen Declaration), the EU's democratic conditionality did not involve specific rules concerning minority rights and civil-military relations at that time.

In Poland and Turkey, the EU developed a more rigorous form of democratic conditionality attached by the European Commission's annual progress reports. As a result, the two countries encountered specific EU requests concerning the ratification of international human rights conventions, respect for minority rights, and democratic control of the armed forces.

The democratic consolidation processes in Spain and Turkey share two major similarities. In both countries, the stateness question and civilian control of the army have been the central challenges to consolidation. The Basque separatism in Spain and the Kurdish separatism in Turkey also posed serious challenges. In addition, military’s involvement in politics and coup plots were among the major troubles for democratic consolidation in Spain and Turkey.

\footnotetext{
${ }^{211}$ One can argue that Turkey's NATO membership has generated some democratic effects such as the spread of democratic norms of civil-military relations among the military officers. For example, Professor Ali Karaosmanoglu contended that Turkey could have witnessed more coup d'états if the country has not been a NATO member (the author's interview in Ankara-December 18, 2009). Yet, these democratic effects remained very limited as demonstrated by the 1960, 1971, 1980, and 1997 military interventions.
} 


\section{Revisiting Hypotheses and the Research Question}

Hypothesis 1: The European integration process, particularly the EU'S

democratic conditionality, favors democratic consolidation in the candidate country but its magnitude is conditioned by domestic factors.

The first hypothesis has found a general support in the analysis of the three case studies. The European integration process, particularly the EU's democratic conditionality contributed to Spain and Poland's democratic consolidation as defined in this dissertation. Likewise, the ongoing process of Turkey's integration with the EU has generated democratizing effects for the four components of consolidation. Table 6.1

provides an overview of the democratizing impact of the European integration process on different components of democratic consolidation in Spain, Poland, and Turkey. 
Table 6.1: The European Integration Process and Four Components of Democratic Consolidation: Spain, Poland, and Turkey in a Comparative Perspective

\begin{tabular}{|c|c|c|c|c|}
\hline & $\begin{array}{l}\text { I. Free, fair } \\
\text { and competitive } \\
\text { elections }\end{array}$ & $\begin{array}{l}\text { II. Protection of } \\
\text { fundamental } \\
\text { rights, human, } \\
\text { and minority } \\
\text { rights }\end{array}$ & $\begin{array}{l}\text { III. Prospect of } \\
\text { regime survival } \\
\text { / civilian control } \\
\text { of the army }\end{array}$ & $\begin{array}{l}\text { IV. Public } \\
\text { legitimacy, elite } \\
\text { consensus, } \\
\text { stateness }\end{array}$ \\
\hline $\begin{array}{l}\text { Spain } \\
(1977-86)\end{array}$ & $\begin{array}{l}\text { anchoring, } \\
\text { reinforcing }\end{array}$ & $\begin{array}{l}\text { reinforcing, no } \\
\text { explicit } \\
\text { conditionality for } \\
\text { minority rights }\end{array}$ & $\begin{array}{l}\text { reinforcing, no } \\
\text { explicit } \\
\text { conditionality in } \\
\text { this area }\end{array}$ & $\begin{array}{l}\text { reinforcing, } \\
\text { strong public } \\
\text { and elite support } \\
\text { for } \\
\text { Europeanization }\end{array}$ \\
\hline $\begin{array}{l}\text { Poland } \\
(1994-2004)\end{array}$ & $\begin{array}{l}\text { anchoring, } \\
\text { reinforcing }\end{array}$ & $\begin{array}{l}\text { helpful, explicit } \\
\text { conditionality for } \\
\text { the ratification of } \\
\text { international } \\
\text { human rights } \\
\text { conventions and } \\
\text { for the promotion } \\
\text { of minority rights } \\
\text { (Roma people, } \\
\text { i.e.) }\end{array}$ & $\begin{array}{l}\text { no direct role as } \\
\text { the key civil- } \\
\text { military relations } \\
\text { reforms made } \\
\text { before the } \\
\text { beginning of } \\
\text { accession } \\
\text { negotiations }\end{array}$ & $\begin{array}{l}\text { indirect } \\
\text { contributions } \\
\text { reinforcing } \\
\text { strong public } \\
\text { and elite support } \\
\text { for 'Return to } \\
\text { Europe' }\end{array}$ \\
\hline $\begin{array}{l}\text { Turkey } \\
\text { (1999-present) }\end{array}$ & $\begin{array}{l}\text { anchoring, } \\
\text { reinforcing }\end{array}$ & $\begin{array}{l}\text { decisive for the } \\
2001-04 \text { reforms } \\
\text { as regards } \\
\text { fundamental } \\
\text { rights and } \\
\text { liberties, human } \\
\text { rights, ethnic and } \\
\text { religious } \\
\text { minority rights } \\
\text { limited } \\
\text { contributions in } \\
\text { the post-2005 } \\
\text { period }\end{array}$ & $\begin{array}{l}\text { decisive for the } \\
2001-04 \text { reforms } \\
\text { as regards civil- } \\
\text { military relations } \\
\text { limited } \\
\text { contributions in } \\
\text { the post-2005 } \\
\text { period }\end{array}$ & $\begin{array}{l}\text { indirect } \\
\text { contributions } \\
\text { converged with } \\
\text { ideational } \\
\text { transformation } \\
\text { of the political } \\
\text { Islamists (the } \\
\text { JDP rule, 2002- } \\
\text { present) }\end{array}$ \\
\hline
\end{tabular}


As discussed in the case study chapters, the EU's democratizing impact is not uniform across different components of the consolidation and over time. As a result, cross sectional and temporal variations arose during the EU accession process. In this regard, domestic factors in the EU candidate countries are notable as they shaped the EU's democratizing leverage. In all three countries, cross-party consensus and strong public support for EU membership enhanced the EU's democratizing leverage.

Change of government during the EU accession process did not result in any shift in the EU's democratizing impact in Spain and Poland. Both the UCD (1977-82) and PSOE (1982-86) governments in Spain were supportive of the accession. Similarly, both Solidarity (1997-2001) and post-Communist (1993-1997, 2001-2004) coalition governments worked for the cause of EU membership. In Spain, political instability and the rise of Basque violence in 1979, 1980, and early 1981 converged with the low profile of Spain-EU relations. As a result, it cannot be a coincidence that the February 23, 1981 coup attempt took place in this period.

In Turkey, change of government in November 2002, from the three-partycoalition government (included a nationalist-EU skeptic party) to the single-powermajority government, resulted in the acceleration of EU promoted political reforms; hence, the change of government extended the EU's democratizing leverage. ${ }^{212}$ The JDP's desire to liberalize strict nationalist and secularist grounds of the Kemalist

\footnotetext{
${ }^{212}$ From the 1999 Helsinki European Council decision of Turkey's official candidate status for EU membership to the fall 2001, the three-party coalition government was slow in responding to the EUTurkey Accession Partnership document, which set short-term and middle-run reforms to fulfill the Copenhagen political criteria. The Nationalist Action Party (MHP) and several Members of Parliament in the Democratic Left Party (DSP) provided a noticeable resistance to the EU's demands concerning the abolition of death penalty, cultural and broadcasting rights for the Kurdish people. For example, the MHP applied to the Constitutional Court for the annulment of several articles in the third EU harmonization law packages (adopted in August 2002) (Erdem 2007: 11-23).
} 
establishment largely converged with the EU promoted political reforms. Later, domestic political crises in the country (the presidential elections, the military's memorandum, and the closure case of the governing party- JDP) in the years 2007 and 2008 worsened the already stagnated relations with the EU since 2005. The governing party did not change, but leverage substantially declined in these years.

Hypothesis 2: The degree to which the candidate country has prospect for membership affects the democratizing leverage of the European Union.

In assessing the democratic effects of the EU accession process for democratic consolidation in the candidate country, a major dynamic is the EU's credible commitment. If the candidate country has a low prospect for membership, it is unlikely that the EU has a high level of democratizing leverage. The three case studies in this dissertation provided clear evidence for this hypothesis. In Spain, the February 23, 1981 coup attempt took place when the Spain-EU relations followed a low profile. ${ }^{213}$ In Poland, the 1993 June Copenhagen European Council meeting was a turning point in terms of the EU's democratizing leverage as the meeting paved the way for the beginning of Poland's accession process. With a clear prospect for membership, conditioned upon fulfilling the Copenhagen criteria, the EU accession process had pronounced democratizing effects with regard to the four components of consolidation (see Table 6.1). Unlike the previous period of 1989-1993, which lacked a clear prospect for

\footnotetext{
${ }^{213}$ In 1979 and 1980, Spain suffered from three major problems: the increasing levels of Basque violence, economic problems, and the governmental crisis, which resulted in the end of Suarez's power. Meanwhile, France was uneasy for Spain's accession to the EU, particularly with a concern that Spain's entry would harm French farmers. As a result, the EU-Spain relations followed a low profile in the wake of the February 23 coup attempt.
} 
membership, the EU executed a greater impact over political reforms in Poland during the accession process (1994-2004).

In Turkey, the 1999-2004 period represents an exceptional era of EU's democratizing leverage as compared to both the pre-1999 and the post-2005 period of Turkey-EU relations. When the December 1999 Helsinki European Council summit recognized Turkey as a candidate country, the EU accession process became a key dynamic behind Turkey's efforts to fulfill the Copenhagen political criteria in order to launch the accession negotiations. Eight EU harmonization law packages and two constitutional amendments adopted in this period resulted in major progress concerning consolidation, particularly in its second and third components (see Table 6.1). After 2005, the declining prospect for EU membership (accession negotiations were partially suspended) substantially lessened the EU's democratizing leverage. Although the EU has continued to monitor Turkey's democracy and made recommendations for further reforms, the post-2005 period shows that the EU has lost most of its democratizing leverage in the country. Unless Turkey has a clear prospect for membership (by setting an accession date, i.e.), it is unlikely that the EU will have a considerable impact on Turkey's democracy in the years to come.

\section{Domestic Dynamics of Democratic Consolidation}

An important part of the research inquiry in this study is the assessment of domestic and non-EU international dynamics of democratic consolidation vis-a-vis the EU's democratizing impact in the three countries. In Spain, two major domestic factors played a role. First, the earlier enactment of democratic constitution (1978) not only 
protected fundamental rights and liberties but also substantially helped the solution of the regional question through formation of autonomous communities. Second, there was broad consensus among the King, the post-Franco right and the socialist-communist left in favor of the democratic regime, which prevented it from several coup plots. Compared to the EU's democratizing role in the accession process, these domestic dynamics were of primary importance. The European integration process became an interdependent part of the post-Franco period of democratization when the Spanish people and political elite provided a wholehearted support for EU membership. The EU accession process played reinforcing and anchoring roles for the re-born Spanish democracy, and accelerated its course of consolidation.

Poland followed a very similar line with Spain: domestic dynamics of democratic consolidation were of primary importance while the EU accession process accelerated the consolidation. The 1997 constitution guaranteed the protection of fundamental rights and liberties including human and minority rights. In addition, the constitution strengthened the 1996 Ministry of Defense Act in particular and civilian control of the military in general. Moreover, Solidarity and the communist successor parties maintained a high consensus on the major political, economic, and foreign policy goals. As in Spain, the European integration process was of secondary importance as compared to domestic factors; however, it became an interdependent element of post-Communist transformation because of its high symbolic significance ('Return to Europe'). The EU accession process reinforced and accelerated the course of democratic consolidation.

In contrast to Spain and Poland, the EU accession process was a primary dynamic of democratic consolidation in Turkey for the years 1999-2004. This period witnessed an 
extraordinary pace of political reforms, which were made to fulfill the Copenhagen political criteria. Particularly notable, the EU's democratic conditionality favored proreform forces in the country against the status quo coalition (hardliner military officers, ultra-nationalists i.e.) who resisted reforms concerning civilian control of the military and expansion of rights for Kurdish and non-Muslim people. Without the EU accession process, including a credible prospect for membership, the civilian governments in this period could have not undertaken these reforms, central to making progress in the second and third component of democratic consolidation. For the years 2002-2004, which involved the highest pace of reforms, two domestic factors played important roles: (i) ideological moderation of political Islamists after the 1997 military intervention that culminated in the JDP rule (2002-present), and (ii) pro-democratic profile of the Chief of Staff prevented the coup plots and facilitated the making of civil-military relations reforms.

When the Turkey-EU relations went into a serious deadlock after 2005, the EU accession process ceased to be a driving force, and Turkey's domestic dynamics became more important in the course of democratic consolidation. In this period, strong public basis of the JDP government made it possible to stand against the April 27, 2007 ememorandum and other cases of resistance by hardliner generals. In the post-2005 period, the government's initiative for the Kurdish question, although remaining very limited, did happen without any considerable EU impact. In addition to the impasse in Turkey-EU relations, domestic political crises in the years 2006-2008 (the April 2007 e-memo and the closure case of the governing JDP i.e.) also negatively influenced undertaking further democratic reforms in the country. As a result, combination of unfavorable domestic and 
European milieu in these years left a little room for making progress in the course of democratic consolidation.

\section{Non-EU International Dynamics of Democratic Consolidation}

Non-EU international dynamics of democratic consolidation in the three countries performed varying levels of impact vis-à-vis the one played by the EU accession process. The NATO accession process (1994-97) clearly helped civil-military relations reforms in Poland. By the time of the EU accession negotiations (1998-2002), Poland had already fulfilled the Copenhagen political criteria, which also required civilian control of the army. In Spain, joining the NATO (1981) facilitated civilian control of the army, particularly by helping re-orientation of the military officers' attention from domestic politics to external security issues. At that time, the area of civil-military relations was not an explicit element of the EU's democratic conditionality. In contrast to Spain and Poland, the EU accession process was clearly more favorable than NATO membership concerning civil-military relations reforms in Turkey. To satisfy the Copenhagen political criteria, Turkey undertook significant reforms in this area in the years 2001-04.

The Council of Europe (CE) membership and the ratification of the European Convention of Human Rights (ECHR) promoted the protection of fundamental rights and liberties, including human and minority rights in three countries. In Spain, the CE conditioned the membership upon holding of democratic elections and respect for human rights policies. In Poland, the CE and the ECHR were helpful particularly in the first years after the democratic transitions while remaining secondary to the Copenhagen conditionality during the EU accession process (1994-2004). In Turkey, the CE 
membership and the ratification of ECHR failed to prevent serious violations of human rights in the 1990s while the EU's democratic conditionality paved the way for undertaking substantial reforms during the accession process, especially in the years 2001-04.

Table 6.2 summarizes the role of domestic and non-EU international dynamics of democratic consolidation in Spain, Poland, and Turkey. In addition, the table includes domestic factors that shaped the EU's democratizing effects (Hypothesis 1) along with the levels of prospect for EU membership (Hypothesis 2) in the three countries.

Table 6.2: Overview of domestic and non-EU international dynamics of democratic consolidation in Spain, Poland, and Turkey

\begin{tabular}{|c|c|c|c|c|}
\hline & $\begin{array}{l}\text { Prospect } \\
\text { for EU } \\
\text { Member } \\
\text { ship }\end{array}$ & $\begin{array}{l}\text { Domestic factors that } \\
\text { shaped the EU's } \\
\text { democratizing effects }\end{array}$ & $\begin{array}{l}\text { Domestic dynamics } \\
\text { of the consolidation }\end{array}$ & $\begin{array}{c}\text { Non-EU } \\
\text { international } \\
\text { dynamics of the } \\
\text { consolidation }\end{array}$ \\
\hline $\begin{array}{l}\text { Spain } \\
(1977-86)\end{array}$ & High & $\begin{array}{l}\text { High public and elite } \\
\text { support for European } \\
\text { integration } \\
\text { UCD }(1977-82) \text { and } \\
\text { PSOE (1982-86) } \\
\text { governments were pro-EU }\end{array}$ & $\begin{array}{l}\text { Earlier enactment of the } \\
\text { democratic constitution } \\
\text { (1978), which } \\
\text { guaranteed fundamental } \\
\text { rights and included the } \\
\text { autonomous } \\
\text { communities formula } \\
\text { The King, post-Franco } \\
\text { right and the socialist- } \\
\text { communist left allied } \\
\text { against the coup plots } \\
\text { High level of public and } \\
\text { elite support for } \\
\text { democratization }\end{array}$ & $\begin{array}{l}\text { The Council of Europe } \\
\text { membership was } \\
\text { conditioned upon } \\
\text { holding of the } \\
\text { democratic elections } \\
\text { and respect for human } \\
\text { rights } \\
\text { European political } \\
\text { parties and party } \\
\text { networks encouraged } \\
\text { and guided the } \\
\text { Spanish political } \\
\text { parties } \\
\text { NATO membership } \\
\text { more than EC } \\
\text { membership helped } \\
\text { civil-military relations } \\
\text { reforms }\end{array}$ \\
\hline
\end{tabular}




\begin{tabular}{|c|c|c|c|c|}
\hline $\begin{array}{l}\text { Poland } \\
\text { (1994- } \\
\text { 2004) }\end{array}$ & High & $\begin{array}{l}\text { High public and elite } \\
\text { support for European } \\
\text { integration } \\
\text { Solidarity (1997-2001) } \\
\text { and post-Communist } \\
\text { (1993-1997, 2001-2005) } \\
\text { governments were pro-EU }\end{array}$ & $\begin{array}{l}\text { The } 1997 \text { constitution } \\
\text { guaranteed fundamental } \\
\text { rights, human and } \\
\text { minority rights; } \\
\text { strengthened civilian } \\
\text { control of the army } \\
\text { Solidarity and post- } \\
\text { Communist parties had } \\
\text { broad consensus on the } \\
\text { major political and } \\
\text { economic reforms }\end{array}$ & $\begin{array}{l}\text { The Council of Europe } \\
\text { Membership and } \\
\text { ECHR were helpful } \\
\text { for the promotion of } \\
\text { fundamental rights, } \\
\text { human and minority } \\
\text { rights } \\
\text { NATO accession } \\
\text { process made direct } \\
\text { contributions to the } \\
\text { acceleration of civil- } \\
\text { military relations } \\
\text { reforms }\end{array}$ \\
\hline $\begin{array}{l}\text { Turkey } \\
\text { (1999- } \\
\text { present) }\end{array}$ & $\begin{array}{l}\text { High, } \\
1999- \\
2004\end{array}$ & $\begin{array}{l}\text { High public and elite } \\
\text { support for European } \\
\text { integration } \\
\text { Majority of people and } \\
\text { political elite in Turkey } \\
\text { still support the } \\
\text { integration but enthusiasm } \\
\text { and expectations } \\
\text { substantially declined } \\
\text { The JDP single power } \\
\text { majority government } \\
\text { accelerated the EU related } \\
\text { reforms (2002-2004) as } \\
\text { compared to the 1999- } \\
\text { 2002 coalition } \\
\text { government, which } \\
\text { included a Turkish } \\
\text { nationalist party. }\end{array}$ & $\begin{array}{l}\text { CGS Hilmi Ozkok } \\
\text { (2002-06) was a } \\
\text { favorable figure for the } \\
2002-04 \text { civil-military } \\
\text { relations reforms and } \\
\text { the failure of coup plots } \\
\text { Strong public basis of } \\
\text { the the JDP government } \\
\text { (2002-present) have } \\
\text { made easier civil- } \\
\text { military relations } \\
\text { reforms and civilian } \\
\text { trial of the coup plots. } \\
\text { Ideational change of the } \\
\text { political Islamists after } \\
\text { the } 1997 \text { military } \\
\text { intervention has been } \\
\text { very helpful. } \\
77 \% \text { of the people } \\
\text { views democracy the } \\
\text { best political regime. }\end{array}$ & $\begin{array}{l}\text { The ECHR have been } \\
\text { helpful for the } \\
\text { promotion of human } \\
\text { and minority rights but } \\
\text { not decisive as much } \\
\text { as the EU's } \\
\text { Copenhagen } \\
\text { conditionality } \\
\text { NATO membership } \\
\text { (since 1952) has failed } \\
\text { to prevent the frequent } \\
\text { military coups while } \\
\text { the military intervals } \\
\text { remained short with } \\
\text { considerations } \\
\text { concerning the US and } \\
\text { EU criticisms. }\end{array}$ \\
\hline
\end{tabular}

${ }^{214}$ According to a poll conducted in May 2011, 69 percent of the Turkish people support the EU membership while 26 percent oppose (Akgun et al 2011). Although the stalemate in Turkey-EU relations after 2005 did not result in a major decrease in public support, the people has considered Turkey's EU membership less as a good thing in 2011 as compared to 2004 (73\% in $2004,63 \%$ in $2005,54 \%$ in 2006 , $40 \%$ in $2007,42 \%$ in $2008,48 \%$ in $2009,38 \%$ in 2010 , and $48 \%$ in 2011). Source: "Transatlantic Trends: Key Findings 2011", The German Marshall Fund of the United States, p.37. Available online at: http://www.gmfus.org/publications_TT/TT2011_final_web.pdf 


\section{Implications for Future Research}

The dissertation attempted to develop a thorough understanding of the democratizing impact of European integration for democratic consolidation in Spain, Poland, and Turkey. In doing so, the study focused on the EU's democratic conditionality during the accession process, and dissected the phenomenon of consolidation into four components. By following a similar structure in each case study chapter, it identified the power and limits of EU's democratizing leverage. In the end, the dissertation found an overall support for the two hypotheses put forward in the beginning: the European integration process favors democratic consolidation but its magnitude is shaped by (i) prospect for EU membership, and (ii) domestic factors in the candidate country. When the EU provides a credible prospect for membership and works with favorable domestic dynamics in the candidate country, the European integration makes significant contributions to different components of democratic consolidation. Otherwise, the EU's democratizing effects remain very limited if the candidate country lacks a credible prospect for membership, and if there is an unfavorable domestic setting.

The study does not conclude that domestic dynamics of democratic consolidation are more or less important than international factors in general. Rather, one has to explore the relative significance of domestic and international dynamics across different components of the consolidation and over time. An important challenge here is the assessment of linkages between domestic and international dynamics of consolidation. For that reason, undertaking further comparative case studies could be very helpful to explore these linkages. 
The dissertation might also have theoretical repercussions for the rationalist and sociological/normative approaches in the existing literature on European integration. When examining public and elite support for the EU membership in the three countries, both approaches could be considered useful. Not only material incentives (EU funds and infrastructure development i.e.) but also symbolic and reputational factors ('Return to Europe' in Poland, overcoming the isolationist Franco legacy in Spain i.e.) played important roles for high levels of public and elite support for the European integration.

The thesis can be applied into the current and potential EU candidate countries to assess the democratizing impact of EU accession process. ${ }^{215}$ For example, one can expect a higher degree of EU's democracy promotion in the current candidate countries vis-à-vis the potential candidate countries as the former have a more credible prospect for EU membership. In addition, the EU is expected to execute more leverage in the countries that have favorable domestic setting for the EU promoted reforms. The way democratic consolidation is defined and dissected into four components could also be applied to analyses of these countries in order to see how the European integration process contributes/will contribute to different aspects of democratization.

Future studies may also focus on one component of democratic consolidation (protection of fundamental rights, including human and minority rights i.e.), and then analyze in detail how the EU accession process contributes to this area in the current and/or potential candidate countries. Moreover, the exploration of domestic factors in the EU candidate countries is another area for future studies. It is possible to examine a

\footnotetext{
${ }^{215}$ In addition to Turkey, Croatia, Iceland, the Former Yugoslav Republic of Macedonia, and Montenegro are the current candidate countries. The EU recognizes Albania, Bosnia and Herzegovina, Serbia, and Kosovo as the potential candidate countries (http://ec.europa.eu/enlargement/candidatecountries/index_en.htm).
} 
single domestic factor across current and/or potential candidate countries to see how that factor enhances or limits the EU's democratizing leverage. Such factors could include ideology of political parties, ethnic nationalism, public and elite support for EU membership.

Finally, the dissertation involves policy implications for the European Union. As the ongoing deadlock in the Turkey-EU relations demonstrates, the EU fails to generate considerable democratizing effects in candidate countries if it does not provide credible prospect for membership. Therefore, the EU should offer a clear green light for accession if it desires to promote democracy effectively in current and potential candidate countries. 


\section{BIBLIOGRAPHY}

Abel, Christopher and Nissa Torrents 1984, Spain: Conditional Democracy, New York: St. Martin's Press

Aguero, Felipe 1995, Soldiers, Civilians, and Democracy: Post-Franco Spain in Comparative Perspective, London: John Hopkins University Press

Ahmad, Feroz 1993, The Making of Modern Turkey, New York: Routledge

Ahmad, Feroz 2008, Bir Kimlik Pesinde Turkiye, Istanbul: Bilgi Universitesi Yayinlari

Akca, Ismet 2009, "Kolektif Bir Sermayedar Olarak Turk Silahli Kuvvetleri” in Bir Zumre, Bir parti: Turkiye'de Ordu, Edited by Ahmet Insel and Ali Bayramoglu, Istanbul: Birikim Yayincilik, pp. 225-270

Akdogan, Yalcin 2006, "The Meaning of Conservative Democratic Political Identity" in The Emergence of a New Turkey: Democracy and the AK Parti, Edited by M. Hakan Yavuz, Salt Lake City: The University of Utah Press, pp. 49-65

Akgun, Mensur et al 2011, Turkiye'de Dis Politika Algisi (Foreign Policy Perceptions in Turkey), TESEV-Open Society Foundation, Istanbul

Almond, G. and S. Verba 1963, The Civic Culture: Political Attitudes and Democracy in Five Nations, NJ: Princeton University Press

Alvarez-Miranda, Berta 1996, "On the Edge of the Community: Southern European Political Debates on Membership", South European Society and Politics, Vol 1., No. 2 (Autumn): 206-228

Anaya, Pilar O. 2002, European Socialists and Spain: The Transition to Democracy, 1959-77, New York: Palgrave

Andrezejewicz, Justyna 2004, "When EU Conditionality Towards the Candidates for Membership Most Effective?" in Strategy of Poland's Membership in the European Union, Edited by J.Kulakowski et al, Warsaw: The Office of the Committee for European Integration, pp: 283-301

Arango, E.Ramon 1995, Spain: Democracy Regained, Boulder: Westview Press

Aras, Bulent et al 2011, Public Perception of the Kurdish Question, Ankara, Turkey: SETA and Pollmark (Available online at: http://www.setadc.org/pdfs/Public_Perception_of_the_Kurdish_Question_in_Turkey.pdf) 
Ash, Timothy G. 1984, The Polish Revolution: Solidarity, New York: Scribner

Asmus, Ronald D. and Thomas S. Szayna 1991, Polish National Security Thinking in a Changing Europe: A Conference Report, California: RAND Publications

Atanasova, G. 2004, "Governance Through Conditionality", Presented at the APSA Annual Meeting, (September 2-5)

Aydinli, Ersel 2011, "Ergenekon, New Pacts, and the Decline of the Turkish "Inner State"”, Turkish Studies, Vol.12, No.2 (June): 227-239

Banon-Martinez, Rafael 1991, "Appendix B: Spanish Military Reform and Modernization" in K. Maxwell (ed.) Spanish Foreign and Defense Policy, Boulder: Westview Press, pp: 237-61

Barany, Zoltan and LouisaVinton 1990, "Breakthrough to Democracy: Elections in Poland and Hungary", Studies in Comparative Communism, Vol.23, No.2 (Summer): $191-212$

Barany, Zoltan D. 1993, "Civil-Military Relations in Comparative Perspective: EastCentral and Southeastern Europe", Political Studies, Vol.41, No.4 (December): 594610

Bayramoglu, Ali 2009, "Asker ve Siyaset” in Bir Zumre, Bir parti: Turkiye'de Ordu, Edited by Ahmet Insel and Ali Bayramoglu, Istanbul: Birikim Yayincilik, pp.59-118

Bell, David 1983, "The Spanish Communist Party in the Transition" in Democratic Politics in Spain: Spanish Politics after Franco, Edited by David S. Bell, London: F. Pinter, pp: 63-77

Ben-Ami, Shlomo 1984, "The Legacy of Francoism-General Perspectives" in Spain: Conditional Democracy, Edited by Christopher Abel and Nissa Torrents, New York: St. Martin's Press

Bernhard, Michael H. 1993, The Origins of Democratization in Poland: Workers, Intellectuals, and Oppositional Politics, 1976-1980, New York: Columbia University Press

Biltekin, Gonca 2007, "Non-Material Sources of Turkish Armed Forces' Political Power: A "Military in Society" Approach", Unpublished Masters' Thesis, Bilkent University, Ankara, Turkey

Birtek, Faruk 1994, "Prospects for a New Center or the Temporary Rise of the Peripheral Asabiyah?" in Politics in the Third Turkish Republic, Edited by M.Heper and A. Evin, Boulder: Westview Press, pp: 223-228 
Biskupski, M.B. 2000, The History of Poland, London: Greenwood Press

Bofoil, Francois 2009, Central and Eastern Europe: Europeanization and Social Change, New York: Palgrave Macmillan

Bonime-Blanc, Andrea 1987, Spain's Transition to Democracy: The Politics of Constitution-Making, London: Westview Press

Borzel, Tanja and Thomas Risse 2007, "Europeanization: The Domestic Impact of EU Politics" in K. Eric Jorgensen, Handbook of European Union Politics, London: Sage Publications, pp: 483-504

Brassloff, Audrey 1998, Religion and Politics in Spain: The Spanish Church in Transition, 1962-96, New York: MacMillan

Bruneau, Thomas C. 2000, Spanish Case Study, The Center for Civil-Military Relations Naval Postgraduate School, Monterey, California, pp: 1-12 (Available online at: http://www.ccmr.org/public/images/download/spanish case study.pdf

Caha, Omer 2005, "The Ideological Transformation of the Public Sphere: The Case of Turkey", Alternatives: Turkish Journal of International Relations, Vol. 4, No.1-2 (Spring and Summer): 1-30

Candar, Cengiz 2011, Dagdan Inis-PKK Nasil Silah Birakir?: Kurt Sorunu'nun Siddetten Arindirilmasi, Istanbul: TESEV (Available online at:

http://www.tesev.org.tr/UD_OBJS/PDF/DEMP/Dagdan\%20Inis-Son\%20Hali-web.pdf)

Caporaso, J. et al 2001, Transforming Europe: Europeanization and Domestic Change, Ithaca, NY: Cornell University Press

Carkoglu, Ali and Binnaz Toprak 2007, Religion, Society, and Politics in a Changing Turkey, Friedrich Ebert Stiftung (FES)-Turkish Economic and Social Studies Foundation (TESEV), Istanbul (Available online at: http://www.tesev.org.tr/UD_OBJS/PDF/DEMP/RSP\%20-\%20Turkey.pdf)

Carothers, T. 2002, “The End of the Transition Paradigm", Journal of Democracy, Vol 13., No. 1

Carr, Raymond and Juan P. Fusi 1981, Spain: Dictatorship to Democracy, London:

George Allen \& Unwin

Castle, Marjorie and Ray Taras 2002, Democracy in Poland, Cambridge, MA: Westview Press 
Cercas, Jaview 2011, The Anatomy of a Moment: Thirty-Five Minutes in History and Imagination, (translated from the Spanish by Anne McLean), New York: Bloomsbury

Checkel, J. 1999, "Norms, institutions, and national identity in contemporary Europe" International Studies Quarterly, 43, 83-114

Chislett, William 1975-78, La Transicion Espanola Vista Por The Times de Londres, The Spanish Transition Foundation, Madrid. Available online at:

http://www.transicion.org/41adocumental.php and

http://www.williamchislett.com/transition-archive/

Cinar, Menderes 2006, "Turkey's Transformation under the AKP Rule", The Muslim World, Vol. 96 (July): 469-486

Cizre, Umit 1997, “The Anatomy of the Turkish Military's Political Autonomy”,

Comparative Politics, Vol. 29, No.2 (January): 151-166

Cizre, Umit 1999, Muktedirlerin Siyaseti: Merkez Sag-Ordu-Islamcilik, Istanbul: Iletisim Yayinlari

Cizre, Umit 2002, 'Egemen Ideoloji ve Turk Silahli Kuvvetleri: Kavramsal ve Iliskisel Bir Analiz”, Modern Turkiye'de Siyasi Dusunce, Cilt: 2 Kemalizm, Iletisim Yayinlari, Istanbul.

Cizre, Umit and Menderes Cinar 2003, Turkey 2002: Kemalism, Islamism, and Politics in the Light of the February 28 Process, The South Atlantic Quarterly, Vol.102, No 2-3 (Spring-Summer): 309-332

Clark, Robert and Michael Haltzel (Eds) 1987, Spain in the 1980s: The Democratic Transition and a New International Role, Cambridge, Massachusetts: Ballinger Publishing Company

Collier, D. (ed) 1979, The New Authoritarianism in Latin America, New Jersey: Princeton University Press

Collier, R. 1999, Paths toward Democracy: The Working Class and Elites in Western Europe and South America, Cambdridge: Cambridge University Press

Colomer, Josep M. 2000, Strategic Transitions: Game Theory and Democratization, Baltimore: The Johns Hopkins University Press

Cooper, Norman 1975, Catholicism and the Franco Regime, Sage Research Papers in the Social Sciences: Volume 3, England 
Cooper, Norman 1976, "The Church: From Crusade to Christianity" in Spain in Crisis: The Evolution and Decline of the Franco Regime, Edited by: Paul Preston, Sussex, UK: The Harvester Press, pp: 48-81

Coskun, Birce A. 2008, “Turkiye'de Siyasi Parti Kapatma ve Avrupa Ornekleri: Parti Kapatmak Demokrasi Tehditi Mi?", Memleket, Vol.3, No.7: 138-152 (Available online at: http://www.siyasaliletisim.org/pdf/siyasipartikapatmak.pdf)

Cottey, Andrew et al 2002, "Introduction: The Challenge of Democratic Control of Armed Forces in Postcommunist Europe" in Democratic Control of the Military in Postcommunist Europe: Guarding the Guards, Edited by Andrew Cottey et al, New York: Palgrave Macmillan, pp: 1-17

Coverdale, John F. 1979, The Political Transformation of Spain After Franco, London: Praeger

Curry, Jane L. 2003, "Poland's Ex-Communists: From Pariahs to Establishement Players" in The Left Transformed in Post-Communist Societies: The Cases of EastCentral Europe, Russia, and Ukraine, Edited by J.L.Curry and J.B.Urban, New York: Rowman and Littlefield Publishers, pp: 19-60

Cwiek-Karpowicz, Jaroslaw and P.M. Kaczynski, Assisting Negotiated Transition to Democracy: Lessons from Poland 1980-1999, Institute of Public Affairs, Warsaw

Dagi, Ihsan 2001, "Islamic Political Identity in Turkey: Rethinking the West and Westernization" CPS Report, International Policy Fellowship Program

Dagi, Ihsan 2006, "The Justice and Development Party: Identity, Politics, and Human Rights Discourse in the Search for Security and Legitimacy" in The Emergence of a New Turkey: Democracy and the AK Parti, Edited by M. Hakan Yavuz, Salt Lake City: The University of Utah Press, pp. 88-106

Dahl, R. 1971 Polyarchy: Participation and Opposition, New York: Yale University Press

Danchin, Peter G. 2002, "External Monitoring and the International Protection of Freedom of Religion or Belief", in Protecting the Human Rights or Religious Minorities in Eastern Europe, Edited by Peter G. Danchin and Elizabeth A. Cole, New York: Columbia University Press, pp: 131-191

Davies, Norman 2001, Heart of Europe: The Past in Poland's Present, New York: Oxford University Press 
Day et al 2000, "International Influences on Democratic Consolidation: Remarks and Hypotheses" in Democratic Consolidation-The International Dimension: Hungary, Poland and Spain, Edited by Gerhard Mangott et al, Germany: Nomos, pp:15-52

De Castro, Ricardo B. 2010, "The European Union, Civil-Military Relations and Secularism in Turkey: An Assessment", Paper prepared for the ECPR Graduate Conference, August 30 (September, Dublin): 1-61

Di Palma, Giuseppe 1990, To Craft Democracies: An Essay on Democratic Transitions, Berkeley: University of California Press

Diamond L. et al (eds) 2005, Assessing the Quality of Democracy, Baltimore, MD: The Johns Hopkins University

Diaz-Ambrona, Juan A.O. 1984, "The Transition to Democracy in Spain" in Spain: Conditional Democracy, Edited by Christopher Abel and Nissa Torrents, New York: St. Martin's Press, pp: 21-39

Dimitrova, A.L. (ed) 2004, Driven to Change: The European Union's Enlargement Viewed from the East, Manchester: Manchester Univ. Press

Dinan, Desmond 2004, "The Road to Enlargement" in E.G. Cowles and D. Dinan (Ends) Developments in the European Union, New York: Palgrave, pp: 7-24

Dodd, C.H. 1965, Politics and Government in Turkey, Berkeley: University of California Press

Dutkiewicz, Piotr 2004, "Postcommunist Civil-Military Relations in Poland" in The Evolution of Civil-Military Relations in East-Central Europe and The Former Soviet Union, Edited by N.L.Mychajlyszyn and H. Riekhoff, Westport, CT: Praeger, pp: 83-102

Eccarius-Kelly, Vera 2011, The Militant Kurds: A Dual Strategy for Freedom, California: Praeger

Echavarria, Juan J.S. 2000, "The International Dimension of the Spanish Constitution" in Democratic Consolidation- The International Dimension: Hungary, Poland and Spain, Edited by Gerhard Mangott et al, Germany: Nomos, pp: 119-132

Edmunds, Timothy et al 2003, "Armed Forces and Society: A Framework for Analysis" in Soldiers and Societies in Postcommunist Europe: Legitimacy and Change, Edited by Anthony Forster et al, New York: Palgrave Macmillan, pp: 1-22

Ekiert, Grzegorz and Jan Kubic 1999, Rebellious Civil Society: Popular Protest and Democratic Consolidation in Poland, 1989-1993, Ann Arbor: The University of Michigan Press 
Erdem, Engin I. 2007, "When Domestic Meets with International: The Political Transformation of Turkey, 1997-2004”, Available at SSRN- Social Science Research Network: http://ssrn.com/abstract=1013126 (September)

Falletti, T. 2006 "Theory-Guided Process-Tracing in Comparative Politics: Something Old, Something New," APSA-CP, Newsletter of the Organized Section in Comparative Politics of the American Political Science Association, vol. 17, pp. 9-14, 2006.

Featherstone, K. \& C. Radaelli (eds) (2003) The Politics of Europeanization, New York: Oxford University Press

Ferry, Martin 2003, "The EU and Recent Regional Reform in Poland", Europe-Asia Studies, Vol.55, No.7 (November): 1097-1116

Fierro, Elena 2003, The EU's Approach to Human Rights Conditionality in Practice, New York: Martinus Nijhoff Publishers

Findley, Carter V. 1980, Bureaucratic Reform in the Ottoman Empire: The Sublime Porte, 1789-1922, Princeton: Princeton University Press

Finnemore, M. 1996, National Interests in International Society, Ithaca, NY: Cornell University Press

Fishman, Robert M. 1990, Working-Class Organization and the Return to Democracy in Spain, London: Cornell University Press

Friszke, Andrzej 2009, 1989: Polish Path Towards Freedom, Warsaw: Sejm

Garcia, Caterina 1995, "The Autonomous Communities and External Relations" in Democratic Spain: Reshaping External Relations in a Changing World, Edited by: Richard Gillespie et al, London: Routledge, pp: 123-140

Garcia, M.G. 1976, “The Armed Forces: Poor Relation of the Franco Regime” in Spain in Crisis: The Evolution and Decline of the Franco Regime, Edited by: Paul Preston, Sussex, UK: The Harvester Press, pp: 23-47

Geddes, B. 2003, Paradigms and Sand Castles, University of Michigan Press

Genieys, William 1998, “Autonomous Communities and the State in Spain: The Role of Intermediary Elites", in Regions in Europe, Edited by Patrick Le Gales and Christian Lequesne, New York: Routledge, pp: 166-180

George, A. \& A. Bennett 2005, Case Studies and Theory Development in the Social Sciences, Cambridge: MIT Press 
Gerring, J. 2004, "What is a Case Study and What Is It Good For?", American Political Science Review 98(2): 341-354

Gogolewska, Agnieszka 1996, "Civilian Control of the Army and Post-1989 Changes in Polish Legislation”, Polish Quarterly of International Affairs, Vol.5, No.1, pp. 61-82

Goldman, Minton F. 1997, Revolution and Change in Central and Eastern Europe: Political, Economic, and Social Challenges, New York: M.E. Sharpe

Gorniak, Jaroslaw et al 2004, On Course? Poland on the Eve of EU Accession: EU Monitoring VII, Krakow, Poland: FES

Gourevitch, P. 1978 "The Second Image Reversed: The International Sources of Domestic Politics", International Organization, Vol. 32, No. 4 (Autumn, 1978), pp. 881912

Gourevitch, P. 1986, Politics in Hard Times, Ithaca, NY: Cornell University Press Gowan, Peter 1990, "Western Economic Diplomacy and the New Eastern Europe", New Left Review, No.182 (July-August): 63-82

Grabbe, H. 2006, The EU's Transformative Power: Europeanization through Conditionality in Central and Eastern Europe, (Palgrave studies in European Union Politics), NY: Palgrave

Grabbe, Heather 2007, "Central and Eastern Europe and the EU" in Developments in Central and East European Politics 4, Edited by Stephen White et al, Durham: Duke University Press, pp:110-126

Grabbe, Heather and K. Hughes 1998, Enlarging the EU Eastwards, London: Pinter/Chatham House Papers

Grabendorff, Wolf 2001, "International Support for Democracy in Contemporary Latin America: The Role of the Party Intellectuals", in Whitehead, Laurence (Ed.) 2001, The International Dimensions of Democratization: Europe and the Americas, New York: Oxford University Press, pp. 201-226

Graham, Robert 1984, Spain: A Nation Comes of Age, New York: St. Martin's Press Guibernau, Montserrat 2004, Catalan Nationalism: Francoism, Transition and Democracy, London: Routledge

Guittet, Emmanuel-Pierre 2008, "Is Consensus a Genuine Democratic Value? The Case of Spain's Political Pacts against Terrorism", Alternatives (July), Vol.33, No.3: 267-291 
Guney, Aylin and Petek Karatekelioglu 2005, "Turkey's EU Candidacy and CivilMilitary Relations: Challenges and Prospects", Armed Forces and Society, Vol.31, No.3 (Spring): 439-462

Gunther, J. and R. Higley 1992, Elites and Democratic Consolidation in Latin America and Southern Europe, New York: Cambridge University Press

Gunther, R. et al (eds) (1995) The Politics of Democratic Consolidation: Southern Europe in Comparative Perspective, Baltimore, MD: The Johns Hopkins University Press

Gunther, Richard (ed) 1993, Politics, Society, and Democracy, Boulder: Westview Press

Gunther, Richard 1986, "The Spanish Socialist Party: Clandestine Opposition to Party of Government" in The Politics of Democratic Spain, Edited by Stanley G. Payne, Chicago: The Chicago Council on Foreign Relations, pp: 8-47

Gunther, Richard 1992, "Spain: The Very Model of the Modern Elite Settlement" in Elites and Democratic Consolidation in Latin America and Southern Europe, Edited by J. Higley and R.Gunther, New York: Cambridge University Press, pp. 38-80

Gunther, Richard et al 1995, The Politics of Democratic Consolidation: Southern Europe in Comparative Perspective, Baltimore: The Johns Hopkins University Press

Haerpfer, Christian W. 2002, Democracy and Enlargement in Post-Communist Europe: The Democratisation of the General Public in Fifteen Central and Eastern European Countries, 1991-1998, New York: Routledge

Hale, William 1994. Turkish Politics and the Military, London: Palgrave

Halmai, Gabor 1995, "The Protection of Human Rights in Poland and Hungary" in Human Rights in Eastern Europe, Edited by Istvan Pogany, England: Edward Elgar

Haughton, T. 2007, "When Does the EU Make a Difference? Conditionality and the Accession Process in Central and Eastern Europe", Political Studies Review, Vol. 5, 233246

Heper, Metin and Aylin Guney 2000, The Military and the Consolidation of Democracy: The Recent Turkish Experience, Armed Forces and Society, Vol.26, No.4 (Summer): $635-657$

Higley, John and Gyorgy Lengyel 2000, "Introduction: Elite Configurations after State Socialism" in Elites after State Socialism, Edited by J.Higley and G.Lengyel, New York: Rowman and Littlefield Publishers, pp: 1-21 
Higley, John and Richard Gunther (eds) 1992 Elites and Democratic Consolidation in Latin America and Southern Europe, New York: Cambridge University Press

Holmes, Peter 1983, "Spain and the EEC" in Democratic Politics in Spain: Spanish Politics after Franco, Edited by David S. Bell, London: F. Pinter, pp: 165-179

Howard, D. and M. Brzezinski 1998, "Development of Constitutionalism" in Transition to Democracy in Poland, Edited by Richard Staar, New York: St. Martin's Press, pp: 133-161

Hughes, J. et al 2004, Europeanization and Regionalization in the EU's Enlargement to Central and Eastern Europe, New York: PalgraveMacmillan

Huntington, S. 1991, The Third Wave: Democratization in the Late Twentieth Century, London: University of Oklahoma Press

Huntington, S.P. 1968, Political Order in Changing Societies, New Heaven, CT: Yale University Press

Hyde-Price, Adrian 1996, The International Politics of East Central Europe, Manchester, UK: Manchester University Press

Insel, Ahmet 2003, "The AKP and Normalizing Democracy in Turkey", The South Atlantic Quarterly, Vol.102, No.2-3: 293-308

Jenkins, Gareth 2006, "Symbols and Shadow Play: Military-JDP Relations, 2002-2004" in The Emergence of a New Turkey: Democracy and the AK Parti, Edited by M. Hakan Yavuz, Salt Lake City: The University of Utah Press, pp.185-206

Johnson, A.Ross et al 1980, East European Military Establishements: The Warsaw Pact Northern Tier, California: RAND Publications

Kalaycioglu, Ersin 2002, "Elections and Governance" in Parties, and Elections in Turkey, Edited by S.Sayari and Y.Esmer, London: Lynne Rienner Publishers, pp: 55-71

Kalaycioglu, Ersin 2005, Turkish Dynamics: Bridge across Troubled Lands, New York: Palgrave Macmillan

Kalaycioglu, Ersin 2010, "Democracy, Islam, and Secularism in Turkey" in The Struggle over Democracy in the Middle East: Regional Politics and External Policies, Edited by Nathan J. Brown et al, London: Routledge, pp: 151-184

Kaldor, Mary 1990, “After the Cold War”, New Left Review, No. 180 (March-April): 2537 
Kanra, Bora 2009, Islam, Democracy and Dialogue in Turkey: Deliberating in Divided Societies, England: Ashgate

Kaptikacti et al 2008, Siyasi Partilerin Kapatilmasi Konusunda Turkiye ve Bazi Ulkelerdeki Yasal Duzenlemeler, TBMM Arastirma Merkezi (Mart): 1-49. Available online at: http://www.pmd.org.tr/dosyalar/parti kapatmalar.pdf.

Karakas, Ercan 2009, Kurt Sorunu: Sosyal Demokratik Yaklasimlar, Istanbul:Kalkedon Yayincilik

Karaosmanoglu, Ali K. 1994, "The Limits of International Influence for Democratization" in Politics in the Third Turkish Republic, Edited by M.Heper and A. Evin, Boulder: Westview Press, pp: 117-131

Kardas, Saban 2008, “Turkey under the Justice and Development Party: Between Transformation of 'Islamism' and Democratic Consolidation?', Critique: Critical Middle Eastern Studies, Vol.17, No.2 (Summer): 175-187

Karpat, Kemal 1959, Turkey's Politics: The Transition to a Multi-Party System, Princeton: Princeton University Press

Katzenstein, P. 1978, Between Power and Plenty: Foreign Economic Policies of Advanced Industrial States, Madison: University of Wisconsin Press

Kayali, Hasan 1995, "Elections and the Electoral Process in the Ottoman Empire, 18761919, International Journal of Middle East Studies, Vol.27, No.3 (August): 265-286 Keck, M. and K. Sikkink 1998, Advocacy Beyond Borders: Advocacy Networks in. International Politics, Ithaca, NY: Cornell University Press

Kelley, J. 2004a, Ethnic Politics in Europe: The Power of Norms and Incentives, Princeton: Princeton Univ. Press

Kelley, J. 2004b, "International Actors on the Domestic Scene: Membership Conditionality and Socialization by International Institutions", International Organization, 58 (Summer), pp. 425-457

Kemp-Welch, A. 2008, Poland under Communism: A Cold War History, New York: Cambridge University Press

Keohane, R. \& H. Milner (eds) (1996) Internationalization and Domestic Politics, Cambridge: Cambridge University Press

Keohane, R. and J. Nye 1977, Power and Interdependence, Boston: Little Brown 
Kerlin, Janelle A. 2005, Social Service Reform in the Postcommunist State:

Decentralization in Poland, College Station: Texas A\&M University Press

Keyman, Fuat and Ziya Onis 2007, Turkish Politics in a Changing World: Global Dynamics and Domestic Transformations, Istanbul: Bilgi University Press

Khagram, S. et al 2002, Restructuring World Politics: Transnational Social Movements, Networks and Norms, Minneapolis: University of Minneapolis Press

Kia, Mehrdad 2008, The Ottoman Empire, Westport, CT: Greenwood Press

Kirchner, Emil J. 1999, "The Role of the EU in Local and Regional Government" in Decentralization and Transition in the Visegrad: Poland, Hungary, the Czech Republic and Slovakia, Emil J. Kirchner (Ed.), New York: St. Martin's Press, pp: 208-222

Kowalczyk, Andrzej 2000, "Local Government in Poland" in Decentralization:

Experiments and Reforms: Volume 1, Tamas M. Horvath (Ed.), Budapest, Hungary: Open Society Institute, pp: 217-253

Kubicek, P. (ed) (2003) The European Union and Democratization, London: Routledge

Kubicek, Paul 2003a, "International Norms, the European Union, and Democratization: Tentative Theory and Evidence" in Paul Kubicek (ed) (2003) The European Union and Democratization, London: Routledge, pp: 1-29

Kubicek, Paul 2003b, "Conclusion: The European Union and Democracy Promotion" in Paul Kubicek (ed) (2003) The European Union and Democratization, London: Routledge, pp: 197-215

Kurczewski, Jacek 1995, The Resurrection of Rights in Poland, Oxford: Clarendon Press Kuron, Jacek 1990, Overcoming Totalitarianism, Journal of Democracy, Vol 1., No.1 (Winter): 72-74

Kuru, Ahmet T. 2006, "Reinterpretation of Secularism in Turkey: The Case of the Justice and Development Party" in The Emergence of a New Turkey: Democracy and the AK Parti, Edited by M. Hakan Yavuz, Salt Lake City: The University of Utah Press, pp.136159

Kuzniar, Roman (ed) 2001, Poland's Security Policy: 1989-2000, Warsaw: Scholar Publishing House

Kuzniar, Roman 2009, Poland's Foreign Policy after 1989, Warsaw: Scholar Publishing House 
Lancaster, Thomas and Gary Prevost 1985, "Introduction: A Coalitional Perspective on Politics and Change in Spain" in Politics and Change in Spain, Edited by Thomas Lancaster and Gary Prevost, New York: Praeger, pp: 1-10

Latawski, Paul 2002, "Democratic Control of Armed Forces in Postcommunist Poland: The Interplay of History, Political Society and Institutional Reform" in Democratic Control of the Military in Postcommunist Europe: Guarding the Guards, Edited by Andrew Cottey et al, New York: Palgrave Macmillan, pp: 21-43

Lecours, Andre 2007, Basque Nationalism and the Spanish State, Las Vegas: University of Nevada Press

Levitt, Barry S. 2006, “A Desultory Defense of Democracy: OAS Resolution 1080 and the Inter-American Democratic Charter", Latin American Politics \& Society, Volume 48, Number 3, (Fall), pp. 93-123

Lewis, Paul and Frances Millard 2001, "The Development of Democratic Institutions in post-Communist Poland" in Prospects for Democratic Consolidation in East-Central Europe, Manchester: Manchester University Press, pp: 180-204

Linden, R. (ed) (2002) Norms and Nannies: The Impact of International Organizations on the Central and East European States, Lanham, MD: Rowman \& Littlefield Publishers

Linz et al 1995, "Democratic Transition and Consolidation in Southern Europe, with Reflections on Latin America and Eastern Europe" in The Politics of Democratic Consolidation: Southern Europe in Comparative Perspective, Edited by Gunther, Richard et al 1995, Baltimore: The Johns Hopkins University Press, pp.77-123

Linz, J. and A. Stepan 1996, Problems of Democratic Transition and Consolidation: Southern Europe, South America, and Post-Communist Europe, Baltimore, MD: The Johns Hopkins University Press

Linz, Juan et al 1995, "Democratic Transition and Consolidation in Southern Europe, with Reflections on Latin America and Eastern Europe in Gunther, R. et al (eds) (1995) The Politics of Democratic Consolidation: Southern Europe in Comparative Perspective, Baltimore, MD: The Johns Hopkins University Press, pp: 77-123

Lipset, S.M. 1959, "Some Social Requisites of Democracy: Economic Development and Political Legitimacy”, American Political Science Review, 53, 69-105.

Llamazares, Ivan and Gary Marks 2006, "Multilevel Governance and the Transformation of Regional Mobilization and Identity in Southern Europe, with Particular Attention to Catalonia and the Basque Country" in Democracy and the State in the New Southern 
Europe, Edited By Richard Gunther et al, New York: Oxford University Press, pp: 235262

MacLennan, Julio C. 2000, Spain and the Process of European Integration: 1957-85, Oxford: Palgrave

Magen, A. and L. Morlino 2008, International Actors, Democratization and the Rule of Law, NY: Routledge

Mainwaring, S. D.Brinks, and A.Peres-Linan 2000, "Classifying Political Regimes in Latin America, 1945-1999”, University of Notre Dame Working Paper \# 280 (September)

Marawall, Jose 1979, Dictatorship and Political Dissent: Workers and Students in Franco's Spain, New York: St. Martin's Press

Marawall, Jose 1982, The Transition to Democracy in Spain, New York: St. Martin's Press

Mardin, Serif 1973, “Center-Periphery Relations: A Key to Turkish Politics?”, Daedalus, Vol.102, No.1 (Winter): 169-190

Marks, Michael P. 1997, The Formation of European Policy in Post-Franco Spain: The Role of Ideas, Interests and Knowledge, Vermont: Ashgate

Martinez, Robert E. 1993, Business and Democracy in Spain, Westport, CT: Praeger Publishers

Maura, Joaquin R. 1976, “After Franco, Franquismo?: The Armed Forces, The Crown and Democracy", Government and Opposition, Vol. 11, No.1 (Winter): 35-64

Maxwell, Kenneth 1991, "Introduction: Spain-From Isolation to Inflience, in Spanish Foreign and Defense Policy, Ed. K. Maxwell, Boulder, CO: Westview Press, pp: 1-17

Maxwell, Kenneth and S. Spiegel 1994, The New Spain: From Isolation to Influence, New York: Council on Foreign Relations Press

McClellan, Grant S. (Ed.) 1978, Spain and Portugal: Democratic Beginnings, New York: The H. W. Wilson Company

McLaren, Lauren 2008, Constructing Democracy in Southern Europe: A Comparative Analysis of Italy, Spain, and Turkey. London: Routledge

Mearsheimer, J. 1994, "The False Promise of International Institutions," International Security, Vol. 19, No. 3 
Medhurst, Kenneth 1978, "The Military and the Prospects for Spanish Democracy", West European Politics, Vol.1, No.1: 42-59

Metiner, Mehmet 2004, Yemyesil Seriat, Bembeyaz Demokrasi, Istanbul: Dogan Kitap

Michnik, Adam 1998, Letters From Freedom: Post-Cold War Realities and Perspectives, Berkeley: University of California Press

Michta, Andrew A. 1990, Red Eagle: The Army in Polish Politics, 1944-1988, California: Hoover Institution Press

Michta, Andrew A. 1997, The Soldier-Citizen: The Politics of the Polish Army after Communism, New York: St. Martin's Press

Michta, Andrew A. 2002, "NATO Standards and Military Reform in Poland: A Revolution from Without" in Norms and Nannies: The Impact of International Organizations on the Central and East European States, Edited by Ronald H. Linden, Oxford: Rowman and Littlefield Publishers, pp: 165-177

Millard, Frances 1999, Polish Politics and Society, London: Routledge

Millard, Frances. 2007, "The Czech Republic, Hungary and Poland," in Developments in Central and East European Politics 4, Edited by Stephen White et.al., Durham: Duke University Press, pp: 37-55

Montero, J. Ramon 1993, "Revisiting Democratic Success: Legitimacy and the Meanings of Democracy in Spain" in Politics, Society, and Democracy, Edited by Richard Gunther, Boulder: Westview Press, pp.140-168

Moore, Barrington. 1966, Social Origins of Dictatorship and Democracy: Lord and Peasant in the Making of the Modern World, Boston: Beacon Press

Morlino, Leonardo 1995, "Political Parties and Democratic Consolidation in Southern Europe" in The Politics of Democratic Consolidation: Southern Europe in Comparative Perspective, Edited by: Richard Gunther et al, London: The Johns Hopkins University Press, pp: $315-88$

Morlino, Leonardo and Jose M. Montero 1995, "Legitimacy and Democracy in Southern Europe", in The Politics of Democratic Consolidation: Southern Europe in Comparative Perspective, Edited by: Richard Gunther et al, London: The Johns Hopkins University Press, pp: 231-60

Mujal-Leon, Eusebio 1986, "The Foreign Policy of the Socialist Government" in The Politics of Democratic Spain, Edited by Stanley G. Payne, Chicago: The Chicago Council on Foreign Relations, pp: 197-255 
Narli, Nilufer 2005, "Civil-Military Relations in Turkey" in The Evolution of CivilMilitary Relations in South East Europe, Edited by Philipp H. Fluri et al, Germany: Physica-Verlag, pp. 229-257

Nash, Elizabeth 1983, "The Spanish Socialist Party since Franco" in Democratic Politics in Spain: Spanish Politics after Franco, Edited by David S. Bell, London: F. Pinter, pp: $29-62$

Ners, Krzysztof J. 1993, "Postcommunist Transformation and Western Support", Polish Quarterly of International Affairs, Vol.2, No.2, pp. 75-81

O’Donnell, G. and P. Schmitter (eds) 1986a, Transitions from Authoritarian Rule (Four Volumes), Baltomore, MD: The Johns Hopkins University Press

O'Donnell, G. and P. Schmitter 1986b, Transitions from Authoritarian Rule: Tentative Conclusions about Uncertain Democracies (v.4), Baltomore, MD: The Johns Hopkins University Press

O'Donnell, G. et al (1986) Transitions from Authoritarian Rule (Four Volumes), Baltomore, MD: The Johns Hopkins University Press

O'Donnell, G. 1996, “Illusions About Consolidation”, Journal of Democracy, Vol.7, No. 2 (April): $34-51$

Okraszewska, Aldona and Jacek Kwiatkowski 2002, "Country Report-Poland: The State of Democracy in Poland's Gminas", The State of Local Democracy in Central Europe, Gabor Soos et al (Eds.), Budapest, Hungary: Open Society Institute, pp: 181-284

Oliveira, Antonio P.S. 1998, "Civil-Military Relations. A Comparative Perspective Between Portugal and Poland in their Pathways to Democratic Consolidation", Unpublished Masters' Thesis, College of Europe, Natolin-Warsaw, Poland

Onis, Ziya 2004, "Turkish Modernisation and Challenges for the New Europe", Perceptions, Vo.9, No.3 (Autumn): 5-28

Ozbudun, Ergun 2000, Contemporary Turkish Politics: Challenges to Democratic Consolidation, London: Lynne Rienner Publishers

Ozbudun, Ergun 2002, 2001 Anayasa Değişiklikleri ve Siyasal Reform Önerileri, Istanbul: TESEV Yayınları

Ozbudun, Ergun 2009, Turkiye'nin Anayasa Krizi, Ankara: Liberte Yayinlari

Ozbudun, Ergun and Omer F. Genckaya 2009, Democratization and the Politics of Constitution-Making in Turkey, New York: Central European University Press 
Ozcer, Akin 2006, Cogul Ispanya: Anayasal Sistemi ve Ayrilikci Terorle Mucadele Modeli, Istanbul, Turkey: Imge Yayinevi

Paczkowski, Andrzej and Malcolm Bryne 2007, From Solidarity to Martial Law: The Polich Crisis of 1980-1981, New York: Central European University Press

Palomares, Cristina 2004, The Quest for Survival After Franco: Moderate Francoism and the Slow Journey to the Polls, 1964-1977, Portland, Oregon: Sussex Academic Press

Papadimitriou, Dimitris 2002, Negotiating the New Europe: The European Union and Eastern Europe, Burlington, VT: Ashgate Publishing

Parla, Taha 2009, "Turkiye'de Merkantilist Militarizm, 1960-1998" in Bir Zumre, Bir Parti: Turkiye'de Ordu, Edited by Ahmet Insel and Ali Bayramoglu, Istanbul: Birikim Yayincilik, pp.201-224

Payne, Stanley 1986, "Modernization of the Armed Forces" in The Politics of Democratic Spain, Edited by Stanley G. Payne, Chicago: The Chicago Council on Foreign Relations, pp: 181-196

Payne, Stanley G. 1967, Franco’s Spain, New York: Thomas Y. Crowell Company Peters, G. 1998, Comparative Politics: Theory and Method, NY: New York University Press

Pevehouse, J. 2005, Democracy from Above: Regional Organizations and Democratization, Cambridge, UK: Cambridge University Press

Pevehouse, Jon C. 2002, "Democracy from the Outside-In? International Organizations and Democratization", International Organization, Volume 56, Number 3 (Summer). pp. 515-549

Pinder, John 1997, "The European Communisty and Democracy in Central and Eastern Europe" in Building Democracy? The International Dimension of Democratisation in Eastern Europe, Edited by Geoffrey Pridham et al, London: Leicester University Press, pp: $110-132$

Plasser, Fritz et al 1998, Democratic Consolidation in East-Central Europe, New York: St. Martin's Press

Pop-Eleches, G. 2007, "Between Historical Legacies and the Promise of Western Integration: Democratic Conditionality After Communism", East European Politics and Societies, Vol. 21, No: 1: 142-161 
Powell, Charles 1995, “Spain's External Relations: 1898-1975" in Democratic Spain: Reshaping External Relations in a Changing World, Edited by: Richard Gillespie et al, London: Routledge, pp: 11-29

Powell, Charles 1996 Juan Carlos of Spain: Self-Made Monarch, Oxford: MacMillan Press

Powell, Charles 2007, “The Franco Dictatorship: A Bifurcated Regime?” in Spain Transformed: The Late Franco Dictatorship, 1959-75, Edited by Nigel Townson, New York: Palgrave Macmillan, pp: 227-247

Powell, Charles 2009, "The Long Road to Europe: Spain and the European Community, 1957-86" in European Integration from Rome to Berlin: 1957-2007, Edited by J.Baquero and C. Closa, Brussels: Peter Lang, pp: 39-63

Powell, Charles T. 1995, "Spain's External Relations 1898-1975" in Richard Gillespie et al (Eds), Democratic Spain: Reshaping External Relations in a Changing World, London: Routledge, pp. 11-29

Powell, Charles T. 2001, "International Aspects of Democratization" in Whitehead, Laurence (Ed.) 2001, The International Dimensions of Democratization: Europe and the Americas, New York: Oxford University Press, pp. 285-314

Pravda, Alex 1982, "Poland 1980: From 'Premature Consumerism' to Labour Solidarity”, Soviet Studies, Vol.34, No.2 (April): 167-199

Pravda, Alex 2001, "Introduction" in J. Ziolanka (ed), Democratic Consolidation in Eastern Europe. Vol. 2: International and Transnational Factors, Oxford: Oxford University Press, pp: 1-28

Preston, Paul 1976, "The Anti-Francoist Opposition: The Long March to Unity" in Spain in Crisis: The Evolution and Decline of the Franco Regime, Edited by: Paul Preston, Sussex, UK: The Harvester Press, pp: 125-156

Preston, Paul 1979, “The Spanish Constitutional Referendum of 6 December 1978”, West European Politics, Vol.2, No.2: 246-49

Preston, Paul 1986, The Triumph of Democracy in Spain, New York: Methuen

Preston, Paul 1990, The Politics of Revenge: Fascism and the Military in TwentiethCentury Spain, London: Unwin Hyman

Preston, Paul 2004, Juan Carlos: Steering Spain from Dictatorship to Democracy, New York: W.W.Norton 
Pridham, G. 2001, "Comparative reflections on democratisation in East-Central Europe: a model of post-Communist transformation?" in G. Pridham and A.Agh (eds) Prospects for Democratic Consolidation in East-Central Europe, Manchester, UK: Manchester Univ. Press

Pridham, G. 2002, "EU Enlargement and Consolidating Democracy in Post-Communist States- Formality and Reality", Journal of Common Market Studies, Vol: 40, No:3, pp: 953-73

Pridham, Geoffrey 1991a, "International Influences and Democratic Transition: Problems of Theory and Practice in Linkage Politics" in G. Pridham (Ed.), Encouraging Democracy: The International Context of Regime Transition in Southern Europe, New York: St Martin's Press, pp: 1-30

Pridham, Geoffrey 1991b, "The Politics of the European Community, Transnational Networks and Democratic Transition in Southern Europe" in G. Pridham (Ed.), Encouraging Democracy: The International Context of Regime Transition in Southern Europe, New York: St Martin's Press, pp: 212-245

Pridham, Geoffrey 1994, “The International Dimension of Democratization: Theory, Practice and Inter-regional comparisons" in G. Pridham (Eds.), Building Democracy? The International Dimension of Democratization in Eastern Europe, New York: St Martin's Press, pp: 7-31

Pridham, Geoffrey 1995, “The International Context of Democratic Consolidation: Southern Europe in Comparative Perspective in Gunther, R. et al (eds) (1995) The Politics of Democratic Consolidation: Southern Europe in Comparative Perspective, Baltimore, MD: The Johns Hopkins University Press, pp: 166-203

Pridham, Geoffrey 2000, The Dynamics of Democratization: A Comparative Approach, London: Continuum

Pridham, Geoffrey 2002, "EU Enlargement and Consolidating Democracy in PostCommunist States - Formality and Reality", Journal of Common Market Studies, Vol. 40, No. 3, pp. 953-73

Pridham, Geoffrey 2002, EU Enlargement and Consolidating Democracy in PostCommunist States-Formality and Reality, Journal of Common Market Studies, Vol. 40, No.3, pp: 953-73

Pridham, Geoffrey 2005, Designing Democracy: EU Enlargement and Regime Change in Post-Communist Europe, New York: Palgrave 
Pridham, Geoffrey 2006, "European Union Accession Dynamics and Democratization in Central and Eastern Europe: Past and Future Perspectives", Government and Opposition, Vol. 41, No. 3, pp. 373-400

Rachwald, Arthur R. 1990, In Search of Poland: The Superpowers' Response to Solidarity, 1980-1989, Stanford, California: Hoover Institution Press

Ragin, C. 1987, The Comparative Method: Moving Beyond Qualitative and Quantitative Strategies, CA: University of California Press

Ram, M. H. 1999, “Transformation Through European Integration: A Comparative Study of the Czech Republic and Romania." Ph.D. dissertation, George Washington University

Rechel, B. 2008, “What Has Limited the EU's Impact on Minority Rights in Accession Countries?”,East European Politics and Societies, Vol. 22, No. 1, pp: 171-91

Remmer, K. 1995, "New Theoretical Perspectives on Democratization”, Comparative Politics, (October): 103-122

Republic of Turkey-Ministry of Foreign Affairs-Secretariat General for EU Affairs, 2007 Political Reforms in Turkey, Ankara

Rose, Richard and Neil Munro 2009, Parties and Elections in New European Democracies, England: ECPR Press

Rose, Richard et al 1998, Democracy and Its Alternatives: Understanding PostCommunist Societies, Baltimore, MD: The Johns Hopkins University Press

Roszkowski, Wojciech and Jan Kaufman 2006, "Chapter 16: Poland" in New Europe: The Impact of the First Decade (Vol.2, Variations on the Pattern), Edited by T.R.Harmstone et al, Institute of Political Studies, Warsaw, pp: 371-427

Rothschild J. and N. Wingfield 2008, Return to Diversity: A Political History of East Central Europe since World War II, New York: Oxford University Press

Rueschemeyer, R et al 1992, Capitalist Development and Democracy, Chicago: University of Chicago Press

Rupnik, J. 2000, “Eastern Europe: The International Context”, Journal of Democracy, Vol. 11, No: 2 (April): 115-129

Rustow, D. 1970, "Transitions to Democracy: Toward a Dynamic Model", Comparative Politics, Vol. 2, No. 3 (April): 337-363

Rustow, Dankward A. 1959 "The Army and the Founding of the Turkish Republic", World Politics, Vol. 11, No. 4. (July), pp. 513-552 
Sanford, George 2002, Democratic Government in Poland: Constitutional Politics Since 1989, New York: Palgrave Macmillan

Sayari, Sabri 2002a, "The Changing Party System" in Parties, and Elections in Turkey, Edited by S.Sayari and Y.Esmer, London: Lynne Rienner Publishers, pp: 9-32

Sayari, Sabri 2002b, "Conclusion" in Parties, and Elections in Turkey, Edited by S.Sayari and Y.Esmer, London: Lynne Rienner Publishers, pp: 179-184

Sayari, Sabri and Yilmaz Esmer (eds) 2002, Politics, Parties, and Elections in Turkey, London: Lynne Rienner Publishers

Schedler, A. 1998, "What is Democratic Consolidation?", Journal of Democracy, Vol. 9, No. 2: 91-107

Schimmelfennig et al 2005, The Europeanization of Central and Eastern Europe, Ithaca, NY: Cornell Univ. Press

Schimmelfennig, F. 2007, "European Regional Organizations, Political Conditionality, and Democratic Transformation in Eastern Europe", East European Politics and Societies, Vol. 21, No. 1: 126-141

Schmitter, Philippe C. 2001, "The Influence of International Context upon the Choice of National Institutions and Policies in Neo-Democracies" in Whitehead, Laurence (Ed.) 2001, The International Dimensions of Democratization: Europe and the Americas, New York: Oxford University Press, pp. 26-54

Schmitter, Phillippe 1986, "An Introduction to Southern European Transitions From Authoritarian Rule: Italy, Greece, Portugal, Spain, Turkey” in O’Donnell et al (Eds.) Transitions from Authoritarian Rule: Southern Europe (v.1), Baltimore, MD: The Johns Hopkins University Press, pp.3-10

Schmitter, Phillippe C. and Imco Brouwer 1999, "Conceptualizing, Researching and Evaluating Democracy Promotion and Protection", Working Paper SPS No. 99/9, European Union Institute,

Serra, Narcis 2010, The Military Transition: Democratic Reform of the Armed Forces, New York: Cambridge University Press

Share, Donald 1985, "Two Transitions: Democratisation and the Evolution of the Spanish Socialist Left”, West European Politics, Vol.8, No.1: 82-103

Share, Donald 1986, The Making of Spanish Democracy, New York: Praeger 
Share, Donald 1989, Dilemmas of Social Democracy: The Spanish Socialist Workers Party in the 1980s, New York: Greenwood Press

Shaw, Stanford J. and Ezel Kural Shaw 1977, History of the Ottoman Empire and Modern Turkey (Volume II: Reform, Revolution, and Republic: The Rise orf Modern Turkey, 1808-1975), New York: Cambridge University Press

Sikkink, Kathryn 2001, “The Effectiveness of US Human Rights Policy, 1973-1980” in Whitehead, Laurence (Ed.) 2001, The International Dimensions of Democratization: Europe and the Americas, New York: Oxford University Press, pp. 93-124

Sikkink, Kathryn 2005. "Patterns of Dynamic Multilevel Governance and the InsiderOutsider Coalition" in Della Porta, Donatella and Sidney Tarrow (Eds) Transnational Protest and Global Activism, Oxford: Rowman and Littlefield Publishers, Inc., pp. 151174

Simon, Jeffrey 2000, Poland: Prepares for the Alliance, Joint Force Quarterly (Summer): 39-44 (Available online at: http://www.dtic.mil/doctrine/jel/jfq_pubs/0925.pdf)

Simon, Jeffrey 2004, Poland and NATO: A Study in Civil-Military Relations, New York: Rowman and Littlefield Publishers

Skocpol, T. 1979, States and Social Revolutions: A Comparative Analysis of France, Russia, and China, New York: Cambridge University Press

Smith, Karen E. 2001, "Western actors and the promotion of democracy" in Democratic Consolidation in Eastern Europe. Vol. 2: International and Transnational Factors, Edited by J. Zielonka et al, Oxford: Oxford University Press, pp: 31-57

Smith, Thomas W. 2007, "Leveraging Norms: The ECHR and Turkey's Human Rights Reforms" in Human Rights in Turkey, Edited by Zehra F.K. Arat, Philadelphia: University of Philadelphia Press, pp: 262-274

Staniszkis, Jadwiga 1984, Poland's Self-Limiting Revolution, New Jersey: Princeton University Press

Story, Jonathan 1977, "Spanish Political Parties: Before and After the Election", Government and Opposition, Vol.12, No.4 (Autumn): 474-495

Sunar, Ilkay and Sabri Sayari 1986, "Democracy in Turkey: Problems and Prospects" in Transitions from Authoritarian Rule: Southern Europe, Edited By G. O'Donnell et al, Baltimore: The Johns Hopkins University Press, pp: 165-186

Swianiewicz, Pawel and M. Herbst 2002, "Economies and Diseconomies of Scale in Polish Local Governments" in Consolidation or Fragmentation? The Size of Local 
Governments in Central and Eastern Europe, Pawel Swianiewicz (Ed.), Budapest, Hungary: Open Society Institute, pp: 219-292

Szayna, Thomas S. 1991, The Military in a Postcommunist Poland, California: RAND

Szczerbiak, Aleks 2004, "Polish Euroscepticism in the Run-Up to EU Accession", European Studies, Vol. 20, pp: 247-268

Szczerbiak, Aleks 2006, "Power without Love: Patterns of Party Politics in Post-1989 Poland", in Post-Communist EU Member States: Parties and Party Members, Edited by S. J.Mulders England: Ashgate, pp: 91-123

Szczerbiak, Aleks 2006, "State Party Funding and Patronage in Post-1989 Poland", Journal of Communist Studies and Transition Politics, Vol.22, No.3 (September ), pp.298-319

Taras, Raymond 1995, Consolidating Democracy in Poland, Colorado: Westview Press

Taspinar, Omer 2004, Kurdish Nationalism and Political Islam in Turkey: Kemalist Identity in Transition, London: Routledge

Tepe, Sultan 2008, Beyond Sacred and Secular: Politics of Religion in Israel and Turkey, Stanford, CA: Stanford University Press

Tezcur, Murat G. 2005, "How Do Political Religious Groups Develop Sustainable Democratic Commitments: The Cases of Iran and Turkey", PhD Dissertation, the University of Michigan

The Birkelbach Report, The European Parliament, December 1961

"The Enlargement of the European Community", European File, 5/79, The European Commission, March 1979

The EU Harmonization Law Packages (2007), The Office of Prime Minister-Secretariat General for European Union, Ankara, Turkey. Available online at: http://www.abgs.gov.tr/files/pub/prt.pdf.

The European Commission Regular Reports on Turkey (1998-2010), Available online at the wesbite of EU's Delegation to Turkey (http://www.avrupa.info.tr/AB ve Turkiye/Muzakereler,Regular Reports.html). The European Council Meeting, Copenhagen, June 1993

The European Council Meeting, Luxembourg, December 1997 
The Turkey-EU Accession Partnership; 2001, 2003, 2006, 2008. Available online at: http://ec.europa.eu/enlargement/candidate-countries/turkey/key-documents/index_en.htm

Tovias, Alfred 1984, "The International Context of Democratic Transition" in The New Mediterranean Democracies: Regime Transition in Spain, Greece and Portugal, Edited by Geoffrey Pridham, London: Frank Cass, pp: 158-171

Tovias, Alfred 1995, "Spain in the European Community" " in Democratic Spain: Reshaping External Relations in a Changing World, Edited by: Richard Gillespie et al, London: Routledge, pp: 88-105

Tsingos, Basilios 2001, "Underwriting Democracy: The European Community and Greece" in Whitehead, Laurence (Ed.) 2001, The International Dimensions of Democratization: Europe and the Americas, New York: Oxford University Press, pp. $315-355$

Tsoukalis, Loukas 1981, The European Community and Its Mediterranean Enlargement, London: George Allen and Unwin

Turan, Ilter 2007, "Unstable Stability: Turkish Politics at the Crossroads", International Affairs, Vol.83, No.2: 319-338

Turkmen, Fusun 2007, “Turkey's Participation in Global and regional Human Rights Regimes" in Human Rights in Turkey, Edited by Zehra F.K. Arat, Philadelphia: University of Philadelphia Press, pp: 249-261

Tusell, Javier 2007, Spain: From Dictatorship to Democracy, 1939 to the Present, Oxford, UK: Blackwell

Unver, H.Akin 2009, “Turkey's 'Deep-State' and the Ergenekon Conundrum", The Middle East Institute Policy Brief, No. 23 (April): 1-25

Usul, Ali Resul 2011, Democracy in Turkey: The Impact of EU Political Conditionality, London: Routledge

Vachudova, M. 2005 Europe Undivided: Democracy, Leverage, \& Integration After Communism, New York: Oxford University Press

Vachudova, Milada A. 2008, "Tempered by the EU? Political Parties and Party Systems before and after Accession", Journal of European Public Policy, Vol.15, No. 6 (September): 861-879

Valenzuela, J. Samuel 1992, "Democratic Consolidation in Post-Transitional Settings: Notion, Process, and Facilitating Conditions" in Issues in Democratic Consolidation: The 
New South American Democracies in Comparative Perspective, Edited by Scott Mainwaring et al, Indiana: University of Notre Dame Press, pp: 57-104

Valenzuela, J.S. 1992, "Democratic Consolidation in Post-Transitional Settings: Nations, Process, and Facilitating Conditions" in Mainwaring, S. et al (eds) (1992) Issues in Democratic Consolidation: The New South American Democracies in Comparative Perspective, Notre Dame, IN: University of Notre Dame Press, pp: 57-104

Vermeersch, Peter 2009, "Poland: Minority Policies in Homogenized State" in Minority Rights in Central and Eastern Europe, Edited by Bernd Rechel, New York: Routledge, pp.166-79

Vidal-Beneyto, Jose 2004, “The Construction of Collective Memory: From Franco to Democracy", Diogenes, 201, pp.17-26

Vilanova, Pedro 1983, "Spain: The Army and The Transition" in Democratic Politics in Spain : Spanish Politics after Franco, Edited by David S. Bell, London: F. Pinter, pp: 147-163

Vinton, Louisa 1995, "Domestic Politics and Foreign Policy, 1989-1993” in Polish Foreign Policy Reconsidered, Edited by Ilya Prizel and Andrew A. Michta, New York: Macmillan, pp: 23-67

Waltz, K. 1979, Theory of International Politics, Reading, Mass: Addison Wesley

Wasilewski, Jacek 1998, "Elite Circulation and Consolidation of Democracy in Poland" in Postcommunist Elites and Democracy in Eastern Europe, Edited by John Higley et al, New York: Macmillan, pp: 163-187

Wesolowski, Wlodzimierz 1996, The Formation of Political Parties in Post-Communist Poland, in Stabilising Fragile Democracies: Comparing New Party Systems in Southern and Eastern Europe, Edited by Geoffrey Pridham and Paul G. Lewis, New York: Routledge, pp: 229-254

Whitehead, L. 1986, “International Aspects of Democratization" in O'Donnell and Schmitter (Eds.) Transitions from Authoritarian Rule: Comparative Perspectives (v.3), Baltimore, MD: The Johns Hopkins University Press, pp. 3-46

Whitehead, L. 1991, "Democracy by Convergence and Southern Europe: A Comparative Politics Perspective" in G. Pridham (Ed.), Encouraging Democracy: The International Context of Regime Transition in Southern Europe, New York: St Martin's Press, pp: 45-61 
Whitehead, L. 2001a, "The Imposition of Democracy: The Caribbean" in Whitehead, Laurence (Ed.) 2001, The International Dimensions of Democratization: Europe and the Americas, New York: Oxford University Press, pp. 59-92

Whitehead, L. 2001b, 'Democracy by Convergence: Southern Europe" in Whitehead, Laurence (Ed.) 2001, The International Dimensions of Democratization: Europe and the Americas, New York: Oxford University Press, pp. 261-284

Whitehead, L. 2001c, "Democracy and Decolonization: East-Central Europe" in Whitehead, Laurence (Ed.) 2001, The International Dimensions of Democratization: Europe and the Americas, New York: Oxford University Press, pp. 356-391

Whitehead, L. 2001d, "Democratic Regions, Ostracism, and Pariahs" in Whitehead, Laurence (Ed.) 2001, The International Dimensions of Democratization: Europe and the Americas, New York: Oxford University Press, pp. 395-412

Whitehead, L. 2001e, "The Enlargement of the European Union: A 'Risky' Form of Democracy Promotion" in Whitehead, Laurence (Ed.) 2001, The International Dimensions of Democratization: Europe and the Americas, New York: Oxford University Press, pp. 415-442

Wiatr, Jerzy J. 1991, "Will Democracy Win in East-Central Europe", Polish Political Science, Vol.21, pp.17-23

Williams, Margit B. 1999, The European Union, Regime Change, And the State: Hungary and Spain Compared, Phd Dissertation, Indiana University

Yaniszewski, Mark 2004, "Civil-Military Relations in Postcommunist Eastern Europe and the Former Soviet Union: Some Theoretical Issues" in The Evolution of CivilMilitary Relations in East-Central Europe and The Former Soviet Union, Edited by N.L.Mychajlyszyn and H. Riekhoff, Westport, CT: Praeger, pp: 19-38

Yavuz, M. Hakan 2006, "Introduction: The Role of the New Bourgeoisie in the Transfrmation of the Turkish Islamic Movement" in The Emergence of a New Turkey: Democracy and the AK Parti, Edited by M. Hakan Yavuz, Salt Lake City: The University of Utah Press, pp. 1-19

Yazici, Serap 2009, Demokratiklesme Surecinde Turkiye, Istanbul: Bilgi Universitesi Yayinlari

Young, Bruce 1983, "The 1982 Elections and the Democratic Transition in Spain" in Democratic Politics in Spain: Spanish Politics after Franco, Edited by David S. Bell, London: F. Pinter, pp: 132-146 
Zaucha, Jacek 1999, "Regional and Local Development in Poland" in Decentralization and Transition in the Visegrad: Poland, Hungary, the Czech Republic and Slovakia, Emil J. Kirchner (Ed.), New York: St. Martin's Press, pp: 53-79

Ziblatt, D. 2006, “How Did Europe Democratize?”, World Politics, Vol. 58, No. 2 , (January), pp. 311-338

Zielonka, J. (ed) (2001) Democratic Consolidation in Eastern Europe. Vol. 2:

International and Transnational Factors. Oxford: Oxford University Press

Ziolanka, Jan 2001, "Conclusions: Foreign Made Democracy" in J. Ziolanka (ed), Democratic Consolidation in Eastern Europe. Vol. 2: International and Transnational Factors, Oxford: Oxford University Press, pp: 511-32

Zirk-Sadowski, Marek 1998, "Chapter 5: The Legal Dimension of European Integration" in Accession or Integration? Poland's Road to the European Union, Edited by Jerzy Hausner et al, Krakow, Poland: FES, pp: 195-239

Zurcher, E.J. et al 2004, The European Union, Turkey and Islam, Amsterdam: Amsterdam University Press 


\section{APPENDICES}

\section{Appendix 1: Field Research Interview Questions}

(1) Do you think the EU accession process has helped democratization in your country?

(2) What are/were the major democratizing effects of European integration for democracy in your country?

(3) What is/was your own position in regard to the EU membership process? Pro-EU or Euro-skeptical?

(4) What is your political orientation in the context of right-left spectrum of politics? (Christian Democrat, Social Democrat, Liberal, Conservative, Nationalist etc.)

(5) Which political party do you support in your country?

(6) In what areas, do you think, the EU accession process has helped democracy in your country? (political stability, basic rights and freedoms, human rights, minority rights, civilian-military relations, economic development etc.)

(7) Do you think democracy in your country has been consolidated in the sense that it is free from major democratic problems, and that it does not involve a substantial risk to revert to an authoritarian regime?

(8) How do you rate the quality of democracy in your country? ( 0 to 10 scale; 10 is the highest score)

(9) In your view, what are/were the major problems of democracy in your country during the EU accession process?

(10) In your view, to what extent political parties differed/differ from each other in regard to the EU accession process?

(11) Do you think European integration is a good thing for your country? Why or Why not?

(12) In your view, what does European integration symbolize for you? (modernization, democratization, political stability, economic development etc.) 


\section{Appendix 2: The List of Interviewees in Spain}

Anonymous Official, Partido Popular, Interview answers received through e-mail on July 30,2009

Antonio Carlos Pereira, Professor of Law at Universidad Santiago de Compostela, Interview answers received through e-mail on February 12, 2010

Antonio Gonzalez Terol, Director General for European Affairs and Cooperation for the Community of Madrid, Interview made on June 24, 2009

Antonio Gutierrez Molina, Partido Popular member of Parliament for Melilla (1996 to present), Second Secretary of the Foreign Affairs Committee, Interview made on June 24, 2009

Charles Powell, Director of Fundacion Transicion Espanola, Professor of Political Science at San

Pablo-CEU University, Interview made on June 29, 2009

Enrique Curiel, former Member of Parliament for PCE (1986-89) and PSOE (1993-96), Senator for PSOE (2004-08), Professor of Political Science at Universidad Complutense de Madrid, Interview made on June 12, 2009

Ignocio Molina, Senior Analyst at Real Instituto Elcano \& Associate Professor of Political Science at Universidad Autonoma de Madrid, Interview made on June 23, 2009

Jorge Verstrynge, former Secretary General of Popular Alliance (AP) (1979-86), former Member of Parliament for Sevilla (AP,1982-86) and for Madrid (PSOE,1986-89), Professor of Political Science at Universidad Complutense de Madrid, Interview made on June 16, 2009

Jose Manuel Fernandez, current Mayor of the town of Bustarviejo (Madrid), former Secretary General of of the United Left's Parliamentary Group (1986-1995), Interview made on July 9, 2009

Josefina Cuesta, Professor of History at Universidad Salamanca, Online communication on July 14,2008

William Chislett, Senior Analyst at Real Instituto Elcano, Time Journalist during the Spanish Transition (1975-78), Interview made on July 28, 2009 


\section{Appendix 3: The List of Interviewees in Poland}

Ageta Dziewlska, Director of European Studies, Centre for Europe, Warsaw University, Interview form filled out in October 2009

Anonymous Official, Office of the Committee for European Integration (UKIE, Warsaw), Interview made on October 15, 2009

Anonymous Official, Polish Information and Foreign Investment Agency (Warsaw), Interview form filled out on October 16, 2009

Cezary Zoledowski, Director of the Institute of Social Policy, Warsaw University, Interview made on September 20, 2009

Dominika Karwoth-Zielinska, Professor of Political Science, Cracow University of Economics, Interview answers received through e-mail on November 1, 2009

Ewa Lyskowska, Professor, Faculty of Economic and Social Problems, Warsaw School of Economics, Interview form filled out in September 2009

Franciszek Golembski, Professor of European Studies, Faculty of Journalism and Political Science, Warsaw University, Interview made on September 15, 2009

Josef Oleksy, Former Prime Minister of Poland (1995-96) and President of the Polish Parliament (1993-97, 2001-05), Interview made in Warsaw on October 24, 2009

Justyna Wiatrowska, High School History Teacher, Meridian International School (Warsaw), Interview form filled out on October 27, 2009

Katarzyna Zakrzeska, Officer in the Bureau of Andrzej Halicki (Deputy and the Chair of Foreign Affairs Committee in the Polish Parliament), Interview answers received through e-mail on October 21, 2009

Klaus Bachmann, Professor of Political Science and a Member of the Governing Board of the Stefan Batory Foundation (Warsaw), Interview answers received through e-mail on October 29, 2009

Kazimierz Starzyk, Professor of Economics, Warsaw School of Economics, Interview made on October 12, 2009

Krzysztof Bobinski, Journalist and Director of the Unia and Polska Foundation (Warsaw), Interview made on September 23, 2009 
Leszek Jesien, Director of European Studies at the Polish Institute of International Affairs (Warsaw), served in Poland's negotiation team for the EU accession, Interview made on September 17, 2009

Maciej Duszczyk, Professor of Political Science and Deputy Director of the Institute of Political Science, Warsaw University, served in Poland's negotiation team for the EU accession, Interview made on October 13, 2009

Malgorzata Mizerska-Wrotkowska, Professor of European Studies, Institute of International Relations, Warsaw University, Interview made on October 16, 2009

Marcin Korolec, Undersecretary of State, Ministry of Economy (Warsaw), Interview made on September 29, 2009

Marek Ostrowski, Jouralist, Foreign Affairs editor of the Polityka Magazine (Warsaw), Interview made on October 26, 2009

Marek Wejtko, Adviser to the Deputy Prime Minister, Minister of Economy, Interview made on September 29, 2009

Mieczyslaw Szostak, Lecturer, Faculty of World Economy, Warsaw School of Economist, Interview form filled out in September 2009

Pawel Poncyljusz, Member of the Parliament from the Party of Law and Justice (PiS), Interview form filled out on October 6, 2009 


\section{Appendix 4: The List of Interviewees in Turkey}

Anonymous Law Professor, Yeditepe University (Istanbul), Interview made on January $7,2010$.

Anonymous Diplomat, the Turkish Ministry of Foreign Affairs, Interview made on December 9, 2009.

Ahmet Kenan Tanrikulu, the Member of Parliament, the Nationalist Action Party (MHP), Interview made on December 15, 2009.

Akin Ozcer, the Retired Turkish Diplomat, Interview made on January 10, 2010.

Ali Carkoglu, Professor of Political Science, Sabanci University (Istanbul), Interview made on December 23, 2009.

Ali Karaosmanoglu, Professor of International Relations, Bilkent University (Ankara), Interview made on December 18, 2009.

Ali Resul Usul, Professor of Political Science, Bahcesehir University (Istanbul), Interview made on December 28, 2009.

Atilla Eralp, Professor of International Relations, The Middle East Technical University (ODTU, Ankara), Interview made on December 17, 2009.

Berdal Aral, Professor of International Relations, Fatih University (Istanbul), Interview answers received through e-mail on January 20, 2010.

Burhan Kuzu, the Member of Parliament, the Justice and Development Party (AKP), Interview made on November 23, 2009.

Cengiz Aktar, Professor of European Studies, Bahcesehir University (Istanbul), Interview made on December 31, 2009.

Ege Erkocak, EU Expert, Directorate of Political Affairs, the Secretariat General of EU Affairs, Interview made on November 18, 2009.

Ersin Kalaycioglu, Professor of Political Science, Sabanci University (Istanbul), Interview made on December 24, 2009.

Hakan Yilmaz, Professor of Political Science, Bogazici University (Istanbul), Interview made on January 14, 2010. 
Huseyin Pazarci, the Member of Parliament, the Democratic Left Party (DSP), Interview made on November 18, 2009.

Lutfi Elvan, the Member of Parliament, the Justice and Development Party (AKP), Interview made on November 12, 2009.

Muhittin Ataman, Professor of International Relations, Abant Izzet Baysal University (Bolu), Interview answers received through e-mail on December 24, 2009.

Murat Mercan, the Member of Parliament, the Justice and Development Party (AKP), Interview made on December 7, 2009.

Mustafa Kaya, Vice Chairman of the Istanbul Provincial Presidency, the Felicity Party (Saadet), Interview made on January 6, 2010.

Ridvan Karluk, Professor of Economics and the EU Expert, Anadolu University (Eskisehir), Interview answers received through e-mail on December 16, 2009.

Saban Disli, the Member of Parliament, the Justice and Development Party (AKP), Interview made on November 17, 2009.

Senem Aydin Duzgit, Professor of International Relations, Istanbul Bilgi University, Interview made on January 11, 2010.

Seyfi Tashan, Director of the Foreign Policy Institute (Ankara), Interview made on December 16, 2009.

Ufuk Uras, the Member of Parliament (Independent), the former chairman of the Freedom and Democracy Party, Interview made on November 13, 2009.

Yilmaz Ensaroglu, Law and Human Rights Director of the SETA (Ankara-based think tank), Interview made on December 10, 2009.

Ziya Muezzinoglu, the Former Minister of Finance, the Chairman of the Turkey-Europe Foundation (TAV, Istanbul), Interview made on December 28, 2009.

Ziya Onis, Professor of International Relations, Koc University (Istanbul), Interview made on January 5, 2010. 
VITA

\section{ENGIN IBRAHIM ERDEM}

\section{Education}

2008-2011

PhD Candidate in Political Science

Department of Politics and International Relations

Florida International University, FL

Research Interests: Comparative Politics, Democratization, Domestic-International Linkages, European Integration, International Relations Theory

2007

M.A. in Foreign Affairs

University of Virginia, VA

$1995-2000$

B.A. in Political Science and International Relations

Bogazici University, Istanbul, Turkey

Professional Experience

2010-2011 Research Assistant, Disaster Risk Reduction Program Florida International University

2009

Research Fellow, University Graduate School

Florida International University

Field Research in Spain, Poland, and Turkey

2005-2009 Teaching Assistant, Department of Political Science

Florida International University

Publications

2007, "When Domestic Meets with International: The Political Transformation of Turkey, 1997-2004", Available at SSRN- Social Science Research Network: http://ssrn.com/abstract=1013126 (August)

2004, "Toward the Central Asian Nuclear Weapon-free Zone”, Journal of Central Asian Studies, Vol. V, No. 2, Spring/Summer, pp: 44-57

2004, "The 'Clash of Civilizations': Revisited After September 11", in Alternatives: Turkish Journal of International Relations, Vol.1, No. 2 (Summer), 2002, pp. 81-107 
2003, Book Review, Power in Transition: The Peaceful Change of International Order, edited by Charles A. Kupchan, Emanuel Adler, Jean-Marc Coicaud and Yuen Foong Khong, New York: United Nations University Press, 2001 ), Millennium: Journal of International Studies, (LSE), Vol. 31, No. 3 (January)

2002 Book Review, The History of Turkey, Douglas A. Howard, Greenwood Press (2001), Turkish Studies (Frank Cass), Fall Vol.3. No.2

Presentations

4/2008, "European Union, Political Parties and Democratization: The Case of Turkey, 1997-2004", MPSA Annual National Conference, Chicago, IL (April 3-5)

4/2006 "European Integration and Democratization: Poland and Spain in Comparative Perspective", MPSA Annual National Conference, Chicago, IL (April 20-23)

2/2004, "Power and Identity in Flux: American Foreign Policy Toward the Middle East", 4th Annual Graduate Student Research Conference, "Innovations in Global Research", GPIS and CRGS, Old Dominion University, Norfolk, Virginia, February 5-6

10/2002 "The 'Clash of Civilizations': Reconsidered After September 11", AMSS 31st Annual Conference, "Muslim World After September 11: Agenda for Change", American University, Washington DC, October 27

10/2002 "The Normative Context of Turkish Foreign Policy in the 1990s", ISA South Conference, Richmond, Virginia, October 19-20

Awards, Grants, and Scholarships

2009 Doctoral Evidence Acquisition Fellowship

University Graduate School

Florida International University

2009 Research Grant

Miami-Florida European Union Center of Excellence

2005-2009 Tuition Waiver and Teaching Assistantship

Department of Political Science

Florida International University

2000 Honors Certificate,

B.A. in Political Science and International Relations

Bogazici University, Istanbul, Turkey 